\title{
Gasification Based Biomass Co-Firing Phase I
}

\author{
Final Report \\ September 2002 \\ (Revised January 2003) \\ Prepared for:
}

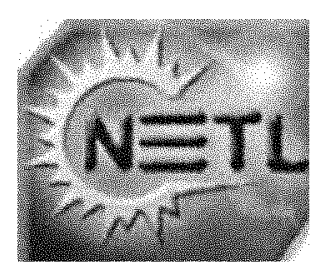

\section{National Energy Technology Laboratory United States Department of Energy Pittsburgh, PA}

DOE Award Number DE-FC26-00NT40898

\author{
Prepared by \\ cNexant \\ San Francisco, CA
}

Principal Investigators

Babul Patel, Nexant Inc., 101 Second Street $11^{\text {th }}$ Floor, San Francisco CA 94105 Kevin McQuigg, Primenergy, LLC, 3172 N. Toledo Street, Tulsa, OK 74158 Robert Toerne, WKE Corp., 145 N. Main Street, Henderson, KY 42419 John Bick, TXU Energy, 1601 Bryan Street, Dallas, TX 75201

Dr. Philip Goldberg, DOE-NETL, 626 Cochrans Mill Road, Pittsburgh, PA 15236 


\section{DISCLAIMER}

"This report was prepared as an account of work sponsored by an agency of the United States Government. Neither the United States Government nor any agency thereof nor any of their employees, makes any warranty, express or implied, or assumes and legal liability or responsibility for the accuracy, completeness, or usefulness of any information, apparatus, product, or process disclosed, or represents that its use would not infringe privately owned rights. References herein to any specific commercial product, process, or service by trade name, trademark, manufacturer, or otherwise does not necessarily constitute or imply its endorsement, recommendation, or favoring by the United States Government or any agency thereof. The views and opinion of authors expressed herein do not necessarily state or reflect those of the United States government or any agency thereof." 


\section{ABSTRACT}

Biomass gasification offers a practical way to use this widespread fuel source for co-firing traditional large utility boilers. The gasification process converts biomass into a low Btu producer gas that can be used as a supplemental fuel in an existing utility boiler. This strategy of co-firing is compatible with variety of conventional boilers including natural gas and oil fired boilers, pulverized coal fired conventional and cyclone boilers. Gasification has the potential to address all problems associated with the other types of co-firing with minimum modifications to the existing boiler systems. Gasification can also utilize biomass sources that have been previously unsuitable due to size or processing requirements, facilitating a wider selection of biomass as fuel and providing opportunity in reduction of carbon dioxide emissions to the atmosphere through the commercialization of this technology.

Nexant Inc., with its team member, Primenergy LLC., and utility partners Western Kentucky Energy Corp. (WKE), and TXU Energy Services, with guidance from Dr. Philip Goldberg of NETL, has undertaken the engineering and economic evaluation of the biomass gasification and co-firing technology under the Department of Energy's Biomass Co-firing program. US DOE's Biomass Program within the office of Energy Efficiency and Renewable Energy sponsored and co-funded this project under a cost share cooperative agreement DOE DEFC26-00NT40898. This study evaluated two plants: WKE's Reid Plant and TXU Energy's Monticello Plant for technical and economical feasibility. These plants were selected for their proximity to large supply of poultry litter in the area.

The Reid plant is located in Henderson County in southwest Kentucky, with a large poultry processing facility nearby. Within a fifty-mile radius of the Reid plant, there are large-scale poultry farms that generate over 75,000 tons/year of poultry litter. The local poultry farmers are actively seeking environmentally more benign alternatives to the current use of the litter as landfill or as a farm spread as fertilizer.

The Monticello plant is located in Titus County, TX near the town of Pittsburg, TX, where again a large poultry processor and poultry farmers in the area generate over 110,000 tons/year of poultry litter. Disposal of this litter in the area is also concern.

This project offers a model opportunity to demonstrate the feasibility of biomass co-firing and at the same time eliminate poultry litter disposal problems for the area's poultry farmers. 


\section{Table of Contents}

DISCLAIMER

ABSTRACT

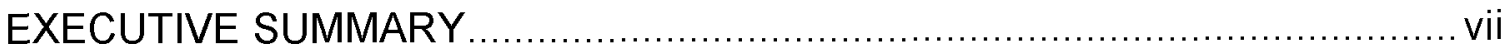

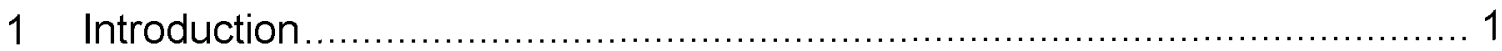

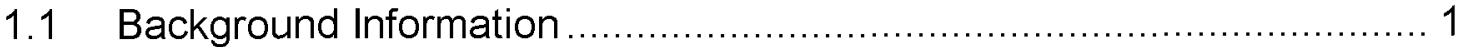

1.2 Gasification Based Cofiring Concept................................................... 2

1.3 Western Kentucky Energy Case ....................................................... 2

1.4 TXU Energy Case ............................................................................. 4

1.5 Primenergy Gasifier ................................................................... 4

1.6 PHASE I Organization, Tasks and Schedule .................................. 6

2 Technology Evaluation ................................................................... 10

2.1 Overview of Co-firing Technologies .............................................. 10

2.1.1 Low Percentage Co-firing: ..................................................... 10

2.1.2 Direct Combustion Co-firing with Separate Feed Systems ............ 10

2.1.3 Issues remaining to be resolved with co-firing ........................... 11

2.2 Gasification Technologies ....................................................... 12

2.3 Hot Gas Filtration System .................................................... 14

2.4 Environmental Impact of Gasification ............................................ 14

2.4.1 Comparison of Coal v/s Litter Burn ......................................... 16

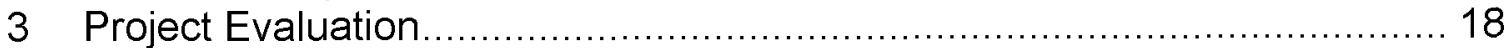

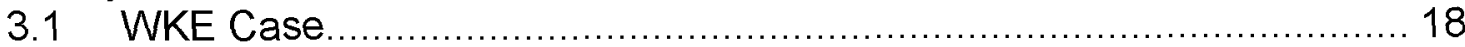

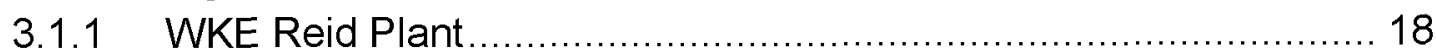

3.1.2 Reid Plant Boiler Data .......................................................... 20

3.1.3 Gasifier Material and Energy Balance .................................... 20

3.1.4 Gasifier Boiler Integration .................................................. 22

3.1.5 Overall Plant Energy Balance .................................................. 23

3.1.6 Solids Handling Systems ..................................................... 24

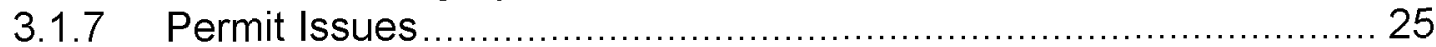

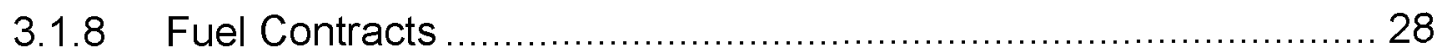

3.1.9 Major Equipment List..................................................... 29

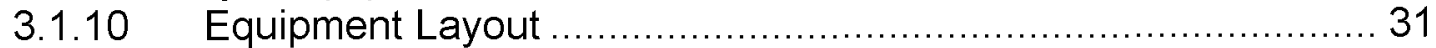

3.2 TXU Energy Case ........................................................................ 32

3.2.1 TXU Monticello Plant ............................................................. 32

3.2.2 Monticello Unit 1 Boiler Data .................................................. 33

3.2.3 Gasifier Material and Energy Balance ................................... 34

3.2.4 Gasifier Boiler Integration .................................................. 36

3.2.5 Overall Plant Energy Balance................................................. 36

3.2.6 Solids Handling Systems ................................................... 37

3.2.7 Permit Issues...................................................................... 41

3.2.8 Fuel Contracts ............................................................... 43

3.2.9 Major Equipment List........................................................ 43

3.2.10 Gasification Plant Layout................................................ 45

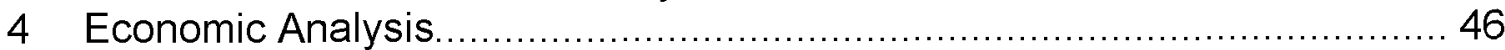


$4.1 \quad$ Reid Plant Case ........................................................................... 46

4.1.1 Capital and O\&M Cost Estimates ........................................ 46

4.1.2 Financial Pro Forma ............................................................ 48

4.1.3 Sensitivity Analysis for Reid Plant Case .................................. 49

4.2 Monticello Unit 1 Case .................................................................... 52

4.2.1 Capital and O\&M Cost Estimate .......................................... 52

4.2.2 Financial Pro Forma ............................................................ 55

4.2.3 Sensitivity Analysis for Monticello Case................................... 56

5 Results and Discussion ............................................................... 57

5.1 Infrastructure/Fuel Supply and Alternative Fuels........................... 57

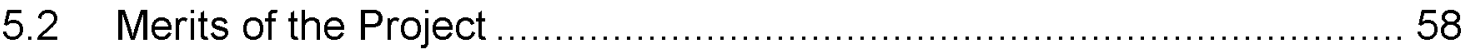

$5.2 .1 \quad$ Energy Benefits and Impacts ................................................ 58

5.2.2 Environmental Benefits and Impacts .................................... 58

5.2.3 Economic Benefits and Impacts .......................................... 59

5.2.4 Infrastructure/Fuel Supply Benefits and Impacts ........................60 60

5.3 Project Sustainability and Opportunities for Replication ...................... 60

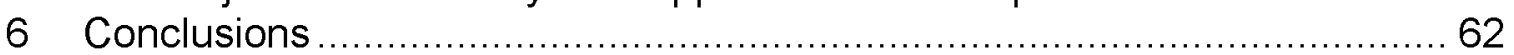

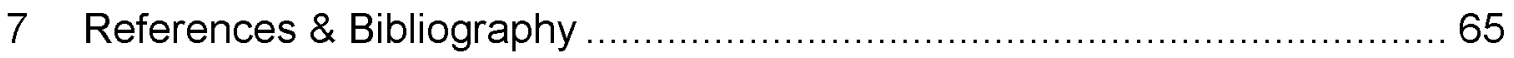

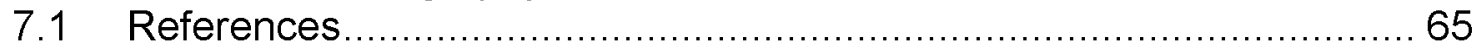

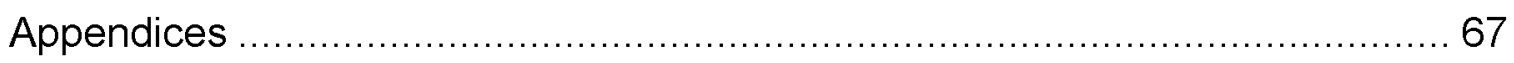




\section{List of Graphical Materials}

Figure 1-1 Gasification Based Biomass Co-firing System Diagram.................... 2

Figure 1-2 Poultry Supply in Vicinity of Reid Plant ......................................... 3

Figure 1-3 Primenergy Gasifier - simplified sketch .................................... 6

Figure 1-4 Project Organization Chart...................................................... 7

Figure 1-5 Interrelationships of Tasks in Phase I ......................................... 8

Figure 1-6 Project Milestone Schedule .................................................... 9

Figure 3-1 Reid Plant Boiler Schematic................................................ 19

Figure 3-2 Heat input to the boiler with cofiring ........................................ 26

Figure 3-3 Expected NOx emissions with cofiring .................................... 27

Figure 3-4 Expected $\mathrm{SO}_{2}$ emissions with cofiring ...................................... 27

Figure 3-5 Monticello Plant Unit 1 ......................................................... 32

Figure 3-6 Heat input to the boiler with cofiring .......................................... 41

Figure 3-7 Reported NOx and SOx emissions at Monticello Plant .................. 42

Figure 4-1 COE Sensitivity to Fuel Price and Ash Credit ............................... 51 


\section{List of Tables}

Table 1-1 Poultry production estimate by Texas Agricultural Department (1997) 4 Table 2-1 Selected Greenhouse Gases Prior to 1850 v/s 1994 ..................... 15

Table 2-2 Unabated Emissions Data for Poultry Litter Test Gasification Run .... 16

Table 2-3 Coal and litter composition and expected emissions...................... 17

Table 3-1 Reid Plant Boiler Operating Data ................................................ 20

Table 3-2 Material Balance for the Gasifier ................................................ 21

Table 3-3 Energy Balance for the Gasifier ................................................ 22

Table 3-4 Energy Balance and Power Production for Reid Plant ..................... 24

Table 3-5 Gasifier Island Equipment List...................................................... 30

Table 3-6 Material Handling System Equipment List...................................... 31

Table 3-7 Design Specifications for Monticello Unit 1 ..................................... 33

Table 3-8 Monticello Boiler Fuel Analyses ................................................... 34

Table 3-9 Material Balance for the gasifier ................................................. 35

Table 3-10 Energy balance for the gasifier............................................... 36

Table 3-11 Energy Balance and Power Production for Monticello Case ............ 37

Table 3-12 Gasifier Island Equipment List............................................... 44

Table 3-13 Material handling equipment list............................................... 45

Table 4-1 Capital Cost Estimates for the Fuel Storage and Conveying............. 46

Table 4-2 Total Capital Cost for WKE's Case ............................................ 46

Table 4-3 Operation, Maintenance and Fuel Cost Estimate - WKE Case ......... 47

Table 4-4 Input Financial Parameters ....................................................... 48

Table 4-5 Levelized Cost of Electricity for WKE Case................................... 49

Table 4-6 COE Sensitivity Analyses for Reid Case ........................................ 50

Table 4-7 Capital Cost Estimates for Fuel Storage and Conveying .................. 52

Table 4-8 Total Capital Cost for the Monticello Plant ...................................... 53

Table 4-9 Operation, Maintenance and Fuel Cost Estimate - Monticello Case .. 54

Table 4-10 Levelized Cost of Electricity for Monticello Case ............................ 55

Table 4-11 COE Sensitivity Analyses for Monticello Case ................................ 56 


\section{EXECUTIVE SUMMARY}

\section{Integration of poultry litter gasification with conventional PC fired power plant}

The purpose of this federally co-funded project is to demonstrate the technical and economical feasibility of biomass gasification and co-firing in an existing pulverized coal fired utility boilers. The primary focus is to use poultry litter as a fuel for the gasification process. However, any other biomass-based fuel that meets the sizing requirements and can be easily transported to the stand-alone gasifier is suitable for this application. Specific objectives of this project are:

- To support commercialization of a biomass co-firing technology that utilizes biomass, agricultural waste and/or farm animal wastes in an environmentally benign, technically practical, and economical application

- To evaluate the technical and economic impact of gasification based co-firing on the existing class of fossil fuel fired boilers currently within proximity of animal waste and agricultural biomass resources of reliable consistency and delivery rates needed for economic operation

- To determine possible modifications, if any, required in either the proposed gasification or boiler technology, for effective utilization of the biomass sources available

- To evaluate these factors specifically for the two plants selected: Reid Plant operated by Western Kentucky Energy Corp., and Monticello Plant operated by TXU Energy

- To develop cost and schedule estimates for implementation at these sites

- To implement such a facility at these sites, provided that the technical and economical evaluations of this study indicate that a useful demonstration of the proposed biomass gasification and co-firing is technically feasible and economically viable

\section{Fuel Supply}

The Reid plant is located adjacent to a large poultry processing plant in southwestern Kentucky with over 500 poultry farmers within a 50 -mile radius of the plant and estimated litter supply of over 75,000 tons per year.

Monticello plant is located in northeastern Texas with similar large poultry processing plant and estimated litter supply of over 110,000 tons per year. Samples of litter form the both of these areas were analyzed and were comparable to litter analysis found in literature.

Primenergy has analyzed poultry litter samples from various sources, and have estimated an average heating value of the as received litter to be about 10,460 $\mathrm{kJ} / \mathrm{kg}(4,500 \mathrm{Btu} / \mathrm{lb})$ and $14,420 \mathrm{~kJ} / \mathrm{kg}(6,200 \mathrm{Btu} / \mathrm{lb})$ on dry basis, making litter as an acceptable biomass fuel source. 


\section{Existing Utility Boilers}

Reid Plant Boiler: The existing Reid Plant boiler is a Riley Stoker forced draft, pulverized coal (PC) fired boiler built in 1964 . The boiler is rated at $313,000 \mathrm{~kg}$ $(690,000 \mathrm{lbs})$ of steam $/ \mathrm{hr}$ at $90.6 \mathrm{Bars}$ and $513^{\circ} \mathrm{C}\left(1300 \mathrm{psig}\right.$ and $\left.955^{\circ} \mathrm{F}\right)$ at the super heater outlet. Primary fuel for the boiler is compliance coal from the local Kentucky coalmines. The boiler was recently converted to a dual fuel system that gives boiler capability of switching to natural gas firing during the NOx mitigation season from May to October.

Monticello Boiler: The unit 1 boiler at the Monticello plant is a Combustion Engineering tangentially fired reheat boiler. The boiler is rated at $1,450,000 \mathrm{~kg}$ $(3,200,000 \mathrm{lbs})$ of steam $/ \mathrm{hr}$ at $248 \mathrm{bars}$ and $814^{\circ} \mathrm{C}\left(3600 \mathrm{psig}, 1005^{\circ} \mathrm{F}\right)$ at the super heater outlet. The reheat flow is $1,270,000 \mathrm{~kg}(2,800,000 \mathrm{lbs})$ of steam/hr at $814^{\circ} \mathrm{C}$ and 38 bars $\left(1005^{\circ} \mathrm{F}\right.$ and $\left.550 \mathrm{psig}\right)$. The boiler fuel is $60 \%$ Texas lignite from the nearby mine and $40 \%$ low sulfur Powder River Basin (PRB) coal from Wyoming.

\section{Proposed Gasifier}

The proposed gasifier is a Primenergy KC-18 system consisting of fuel receiving and storage system, fuel feed system, gasifier(s), hot gas filtration system and a two stage after burner combustion system. A single $\mathrm{KC}-18$ will handle $7.6 \mathrm{t} / \mathrm{h}$ ( 8.4 tons/hr) of poultry litter. The KC Reactor/Gasifier is a sub atmospheric pressure, fixed bed, air blown, updraft gasifier. The project evaluated a single $\mathrm{KC}-18$ gasifier for the Reid plant application and twin KC-18 gasifier system for the Monticello plant.

In each gasifier, fuel is introduced by a water-cooled screw conveyor that discharges into the drying and heating zone of the gasifier. The gasification process is controlled by the proportioned injection of gasification and combustion air in a manner that supports efficient gasification. Residence time in the gasifier is varied by a control system that is adjusted to achieve the desired gasification temperature and minimize carbon content of the ash discharged from the gasifier. The use of mechanical bed agitation, precise gasification air control and zoning produces a clean, combustible gas with heating value of between 3,170 $5,220 \mathrm{~kJ} / \mathrm{M}^{3}$ (85 to $140 \mathrm{Btu} / \mathrm{cu}$. ft.). In order to minimize impact of the external gasifier on the existing boiler operation, the gases are filtered through hot ceramic filters to remove particulates and other contaminants.

Ash from the poultry litter gasification retains phosphorous and potassium present in the litter while the fuel bound nitrogen is lost with the gasification products. The ash has potential value as P\&K fertilizer. The project has investigated potential application and market for the gasifer ash. 


\section{Boiler Gasifier Integration}

The low Btu gas from the gasifier (producer gas) is at $840^{\circ} \mathrm{C}\left(1550^{\circ} \mathrm{F}\right)$ and has a calorific value of about $4,100 \mathrm{~kJ} / \mathrm{M}^{3}$ (110 Btu/std. cu. ft.) The gas is burned in a two-stage combustor, which raises the temperature of the gas to about $1275^{\circ} \mathrm{C}$ $\left(2330^{\circ} \mathrm{F}\right)$. The gas can be fed into any existing boiler at a suitable location as additional or supplemental heat input. For the Reid and Monticello plant, the cleaned hot gases can be fed above the existing coal burners, allowing the reduction of the coal, the primary fossil fuel fired into the boiler.

It is estimated that for the Reid case, about $8 \sim 10 \%$ of heat input can be provided from the gasifier gases, which can allow Reid operators to reduce proportionate amount of coal to the boiler. Similarly, for the Monticello plant $\sim 1 \%$ of the heat input into the boiler can be provided with the twin gasifier system.

\section{Conclusions}

Due to low sulfur content in the poultry litter, and two-stage combustion process, the gasifier is expected to reduce the $\mathrm{SO}_{2}$ and $\mathrm{NOx}$ emission from the boiler. With the hot gas filtration system, clean producer gas can be fed into the existing boiler, thus reducing particulate loading on the gas filtration system such as electrostatic precipitator (ESP) or bag house filters of the existing boiler.

Poultry litter is a renewable energy resource. Any fossil fuel fired boilers can proportionately reduce their fossil fuel consumption by gasification based cofiring and can claim a reduction in greenhouse gas emissions (CO2) from their boiler. The process is technically feasible. Project was able to get concurrence from respective boiler vendors on feasibility of installing additional gas burners on the boiler to fire producer gas from the gasifier. The size and locations of these burners are boiler dependent.

Although, this approach is technically feasible, current economic conditions, and low fuel prices for the coal, primary boiler fuel in the cases examined, did not provide economic incentives for the two utilities (WKE and TXU) to proceed with the demonstration phase of this work. A demonstration phase can provide an opportunity for actual construction of gasifiers at the sites selected and demonstration of the technical feasibility and economic evaluation of gasification based cofiring concept. 


\section{Introduction}

This proposed study is to evaluate technical and economical feasibility of integrated biomass gasification and co-firing in an existing utility boiler. The project examined two different sites: Reid Plant boiler operated by Western Kentucky Energy and Monticello Plant operated by TXU Energy. Primary focus of the study was to utilize poultry litter as a fuel for external gasification and feed the resulting low Btu producer gas into the existing utility boiler at these sites. Specific objectives of this project are:

- To evaluate the technical and economic feasibility of gasification based cofiring on the existing class of fossil fuel fired boilers currently within range of animal waste and agricultural biomass sources of reliable consistency and delivery rates needed for economic operation

- To determine possible modifications, if any, required in either the proposed gasification or boiler technology, for effective utilization of the biomass sources proposed

- To evaluate these factors for two specific cases: for the Reid Plant operated by Western Kentucky Energy Corp. and Monticello Plant operated by TXU Energy.

- To develop detailed cost and schedule estimates for implementing gasification based biomass co-firing at these two facilities.

- Future implementation of such a facility if all of the estimates and evaluations indicate that a useful demonstration of the proposed biomass gasification and co-firing technology can be economically justified.

- To support commercialization of biomass co-firing technology that utilizes biomass, agricultural waste and farm animal wastes in an environmentally benign, technically practical application, provided it is economically viable.

\subsection{Background Information}

The technical and economic feasibility study was conducted for WKE's Reid plant located in Henderson County, KY, and for TXU Energy's Monticello plant located in Titus County, TX. Detailed background information on the Reid plant, Monticello plant and Primenergy's fixed bed updraft gasifier is provided in Section 3. For both cases Primenergy, LLC, KC-18 series gasifiers were selected, a single KC-18 for the Reid plant and twin KC-18 system for the Monticello case were considered. Nexant, Primenergy and Western Kentucky Energy (WKE) for the Reid case and Nexant, Primenergy and TXU evaluated a gasification system to be located in the vicinity of the existing boilers to provide 
producer gas as a supplemental fuel and to displace a portion of the primary boiler fuel, coal and / or natural gas.

\subsection{Gasification Based Cofiring Concept}

The gasification based cofiring can best be represented by the following schematic in figure 1-1. As shown in the schematic, the primary boiler fuel and the biomass fuel are treated and utilized separately. This approach avoids the traditional problems associated with cofiring, where biomass is directly introduced in to an existing boiler, namely fuel handling and fuel delivery into the boiler, boiler slagging and altered ash characteristics and based on moisture content of the biomass an altered combustion pattern within the boiler.

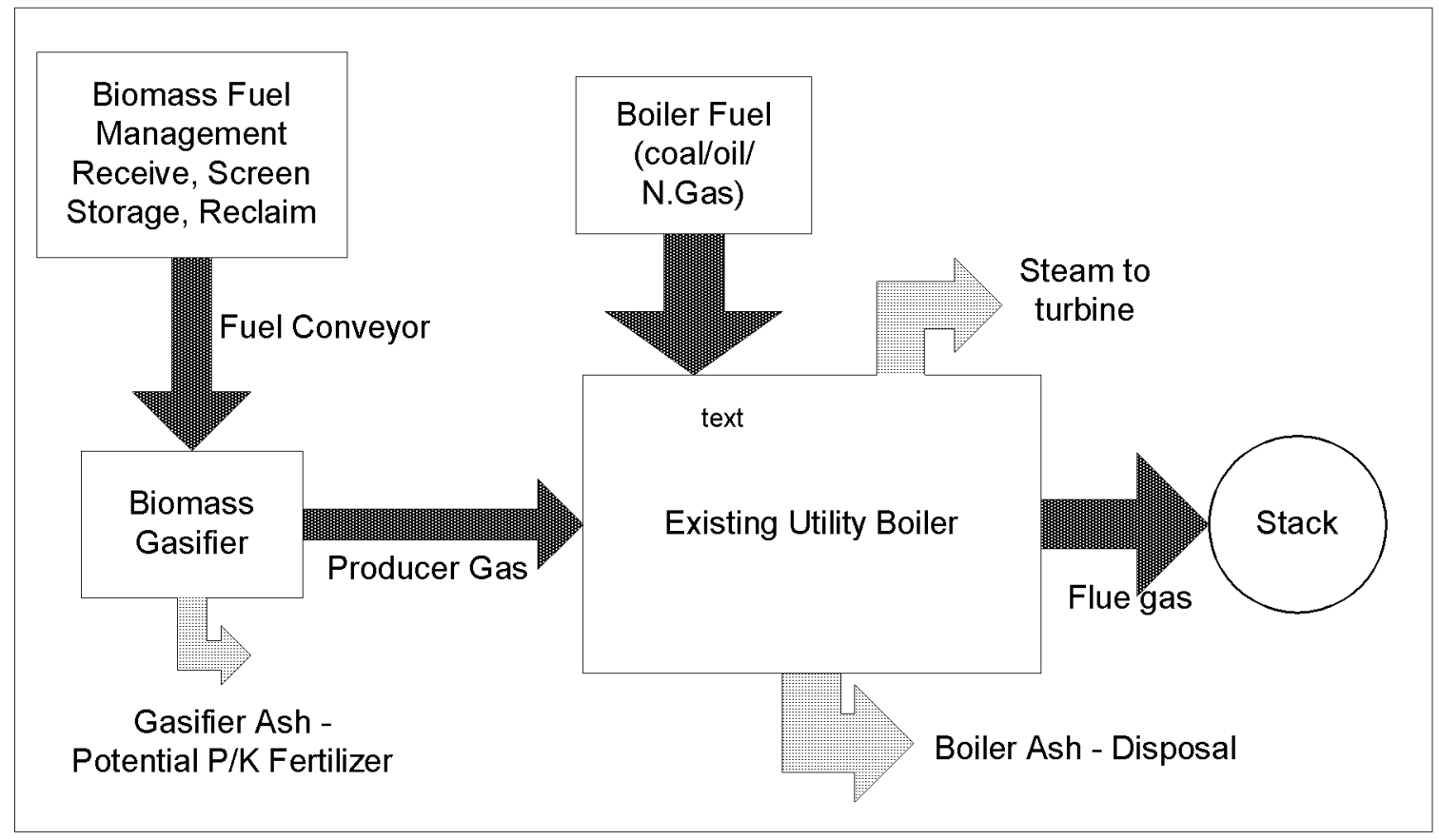

Figure 1-1 Gasification Based Biomass Co-firing System Diagram

\subsection{Western Kentucky Energy Case}

The WKE's Reid plant is located near Henderson, Kentucky. It is a $63 \mathrm{MWe}$ coal-fired unit with a pulverized coal-fired Riley Stoker boiler. The boiler uses Western Kentucky coal. The boiler has maximum continuous capacity (MCR) of $313,000 \mathrm{~kg}(690,000 \mathrm{lbs})$ of steam $/ \mathrm{hr}$ at 90.6 Bars and $513^{\circ} \mathrm{C}(1300 \mathrm{psig}$ and $\left.955^{\circ} \mathrm{F}\right)$ at the super heater outlet.

The Reid plant operated by WKE in Henderson County is in an ideal location for the proposed demonstration project since it is adjacent to a Tyson Foods chicken 
processing plant and associated chicken farms. The total yield of poultry litter from the farmers in the vicinity is expected to be a greater than 75,000 tons per year. Figure 1-2 show concentration of poultry farmers within 50 -mile radius in Western Kentucky, with center at McLean County, about 20 miles from the Reid plant. ${ }^{1}$ The map shows that within 50 -mile radius, there are 668 poultry houses. These poultry farmers are primarily associated with the Tyson Foods plant near the Reid plant in Robards, KY. Another poultry producer, Purdue Farms operate a large processing plant in Cromwell, $\mathrm{KY}$, about 65 miles due southeast from the Reid Plant. Poultry farmers associated with Purdue Farms may overlap in this map.

Western Kentucky Poultry Growers Nutrient Processing Center

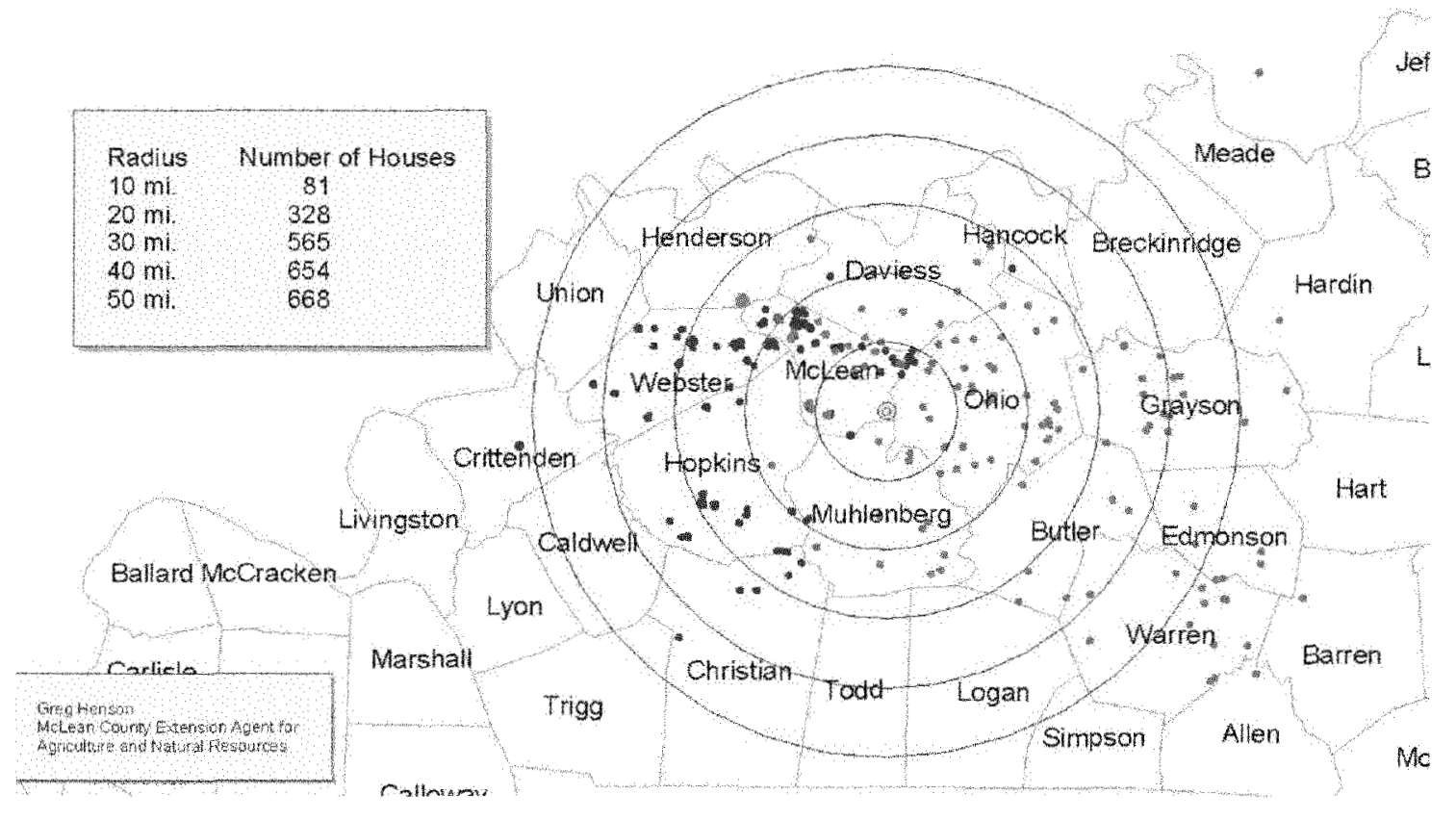

Figure 1-2 Poultry Supply in Vicinity of Reid Plant

For the Reid plant a single gasifier with 8 tons/h of litter (54,000 tons/year) was considered. This provided about $10 \%$ of the total boiler energy input from the gasification based cofiring. A detailed technical and economical analysis for this case is provided in Section 3. 


\subsection{TXU Energy Case}

TXU Energy's Monticello Plant is located near the cities of Mount Pleasant and Pittsburg in Titus County, TX. The Monticello is a 3-unit coal/ Texas lignite fired plant. For this study, Monticello Unit 1 was selected. The unit 1 Monticello boiler is a Combustion Engineering tangentially fired reheat boiler. The boiler is rated at $1,451,500 \mathrm{~kg}(3,200,000 \mathrm{lbs})$ of steam $/ \mathrm{hr}$ at $250 \mathrm{Bars}(3600 \mathrm{psig})$ and $540^{\circ} \mathrm{C}$ $\left(1005^{\circ} \mathrm{F}\right)$ at the super heater outlet. The reheat flow is $1,270,000 \mathrm{~kg}(2,800,000$ lbs) of steam $/ \mathrm{hr}$ at $540^{\circ} \mathrm{C}\left(1005^{\circ} \mathrm{F}\right)$ and 40 Bars (550 psig). The boiler is fueled by $60 \%$ Texas lignite from the nearby mine and $40 \%$ low sulfur Powder River Basin (PRB) coal from Wyoming.

The Monticello plant is also an ideal location for poultry litter supply. Table 1-1 below shows estimated poultry, broiler, and pullets production within six county regions around the Monticello plant. ${ }^{2}$

Table 1-1 Poultry production estimate by Texas Agricultural Department (1997)

\begin{tabular}{|c|c|c|c|c|c|c|}
\hline \multicolumn{1}{|c|}{ County } & Camp & Titus & Franklin & Morris & Wood & Total \\
\hline $\begin{array}{l}\text { Total broilers/pullets } \\
\text { and other chickens }\end{array}$ & $50,359,409$ & $18,223,679$ & $15,081,030$ & $5,783,000$ & $14,183,669$ & $\mathbf{1 0 3 , 6 3 0 , 7 8 7}$ \\
\hline
\end{tabular}

Estimating about $1 \mathrm{~kg}$ ( $2 \mathrm{lbs}$.) of litter and bedding material per bird, there is estimated $100,000 \mathrm{t} / \mathrm{y}(105,000$ tons/year) of litter supply in the vicinity of the plant. Pilgrim's Pride, the large poultry processor in Mount Pleasant and Pittsburg, TX estimates that there is nearly 200,000 tons/year of litter supply in the $80 \mathrm{~km}$ (50-mile) radius of the plant.

For TXU case, we designed gasifier for a feed rate of $14,350 \mathrm{t} / \mathrm{h}$ of litter or about 115,000 t/year of litter consumption. This rate produces about $2 \%$ of the total energy input to the Monticello Unit 1 boiler.

\subsection{Primenergy Gasifier}

The Primenergy gasifier is a fixed-bed updraft system. Because this gasifier is a sub atmospheric and an updraft device, it is a comparatively lower cost system than other types of gasifiers. In the updraft system most of the tars are cracked by partial oxidation of the product gas, which increases the temperature of the product while reducing the condensable long chain and cyclical hydrocarbons to fragments. Figure 1-3 is a schematic of the Primenergy gasifier.

The Primenergy gasifier has already been used for electricity generation in stand-alone plants. Typically it is installed to gasify biomass, with the gas being combusted immediately and ducted to a heat recovery steam generator (HRSG). The HRSG then generates the steam for use in a turbine. The largest design for a single Primenergy gasifier is $100 \times 10^{6} \mathrm{~kJ} / \mathrm{h}\left(100 \times 10^{6} \mathrm{Btu} / \mathrm{hr}\right)$. Multiple gasifiers 
can be installed to increase overall system capacities. Typical capacities of the electricity generating systems based upon the Primenergy gasifier are less than $15 \mathrm{MWe}$, and the typical HRSG steam conditions have been at or below 60 Bars (850 psig).

These stand-alone plants have been installed to manage rice hulls and rice straw, wood waste, switchgrass, and other feeds. The gasifier has shown that it can successfully handle materials up to 50-55 percent moisture, although the product gas quality suffers with high moisture feedstock. Testing for the Southeast Regional Biomass Energy Program (SERBEP) has demonstrated the substantial feedstock flexibility of this system.

Among the Primenergy gasification applications is the $300 \mathrm{t} / \mathrm{d}$ (330-ton/day) rice hull gasifier installed for Cargill Rice Milling of Greenville, MS. This installation delivers sufficient heat to a HRSG to generate $5 \mathrm{MW}$ of electricity, and $6,800 \mathrm{~kg} / \mathrm{h}$ $(15,000 \mathrm{lb} / \mathrm{hr})$ of process steam. Key to this installation are methods for removing virtually all of the ash as bottom ash while generating a gas that is substantially free of tars through partial oxidation of the gas exiting the gasifier itself. Other applications of this system with different fuel exhibit similar characteristics. 


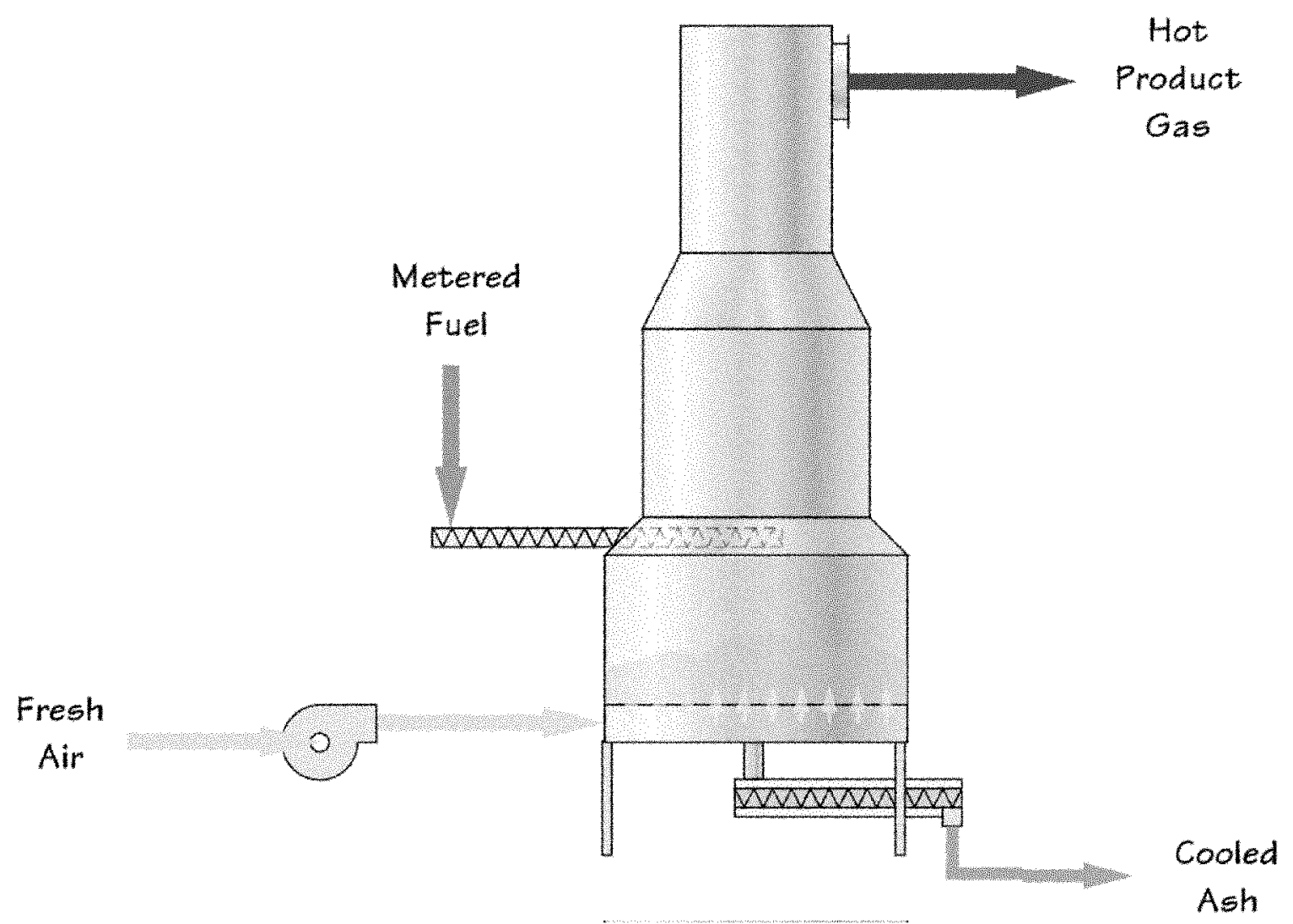

Figure 1-3 Primenergy Gasifier - simplified sketch

\subsection{PHASE I Organization, Tasks and Schedule}

The gasification based biomass co-firing project has reviewed and evaluated technical feasibility and economical viability of building and operating poultry litter gasifier at WKE's Reid plant near Henderson, KY, and TXU Energy's Monticello plant near Mount Pleasant and Pittsburg, TX. The project has reviewed the existing plant design and operation; evaluated available poultry litter supply, and prepared preliminary engineering design; specification and plant layout for construction and installation of the gasifier systems. The project also estimated impact on plant emissions due to cofiring. Based on the engineering design, plant layout, and fuel cost, project has prepared a pro-forma cost analysis for both WKE and TXU cases.

The overall project was planned for two phases. Under Phase I, the project has addressed feasibility and economic issues. If economically viable and if desired by the respective utility/ plant owners, a Phase II actual demonstration of the technology can be pursued. At present, due to unfavorable economics, the two participating utilities, WKE and TXU have not committed to the Phase II. 
During the Phase I, the project team undertook a detailed feasibility study of integrating the existing utility boiler plant with Primenergy's gasifier unit utilizing poultry litter as primary feedstock. Project Organization for the Phase I study is shown here in figure 1-4.

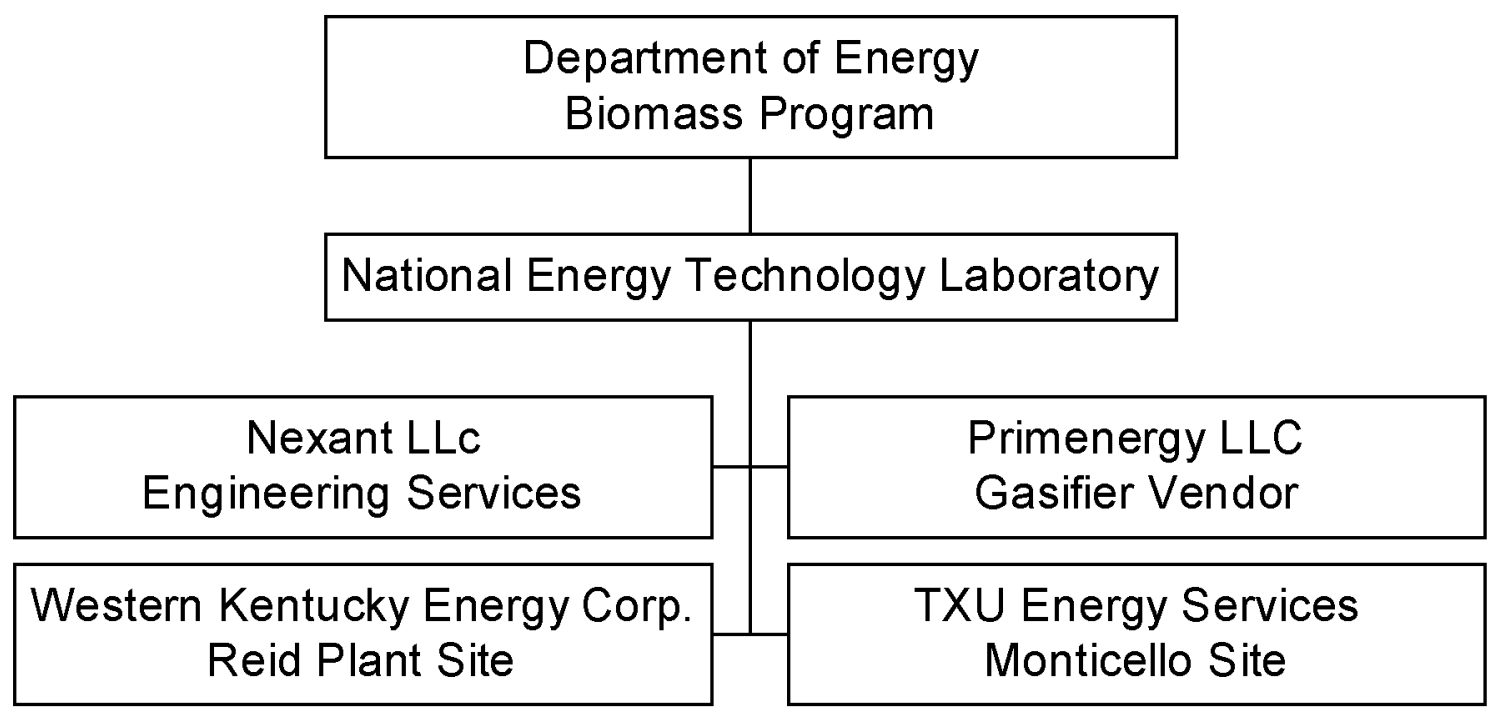

Figure 1-4 Project Organization Chart

The specific tasks that were performed under Phase I are:

- Conceptual engineering of the gasification facility, including the fuel handling aspects of the facility

- Equipment selection, integration with existing boiler and plant layout

- Fuel characterization, including proximate and ultimate analysis of the poultry litter, Btu content, moisture and size variation, ash characterization.

- Fuel availability assessments, focusing upon the availability of low, zero, and negative cost biomass. This effort is concentrated on locally available poultry litter, but project has also examined other biomass in the area.

- Modeling of the existing boiler to determine any de-rating issues 
- Economic assessment of gasification-based co-firing evaluating the fuel cost implications on the overall cost of power generation

A detailed work plan by major tasks for Phase 1 is provided here. Figure 1-5 illustrates the logical flow of work undertaken in this program. At each of these stages, criteria for proceeding to the next stage were established. When the concept met all of the technical requirements than economical feasibility was assessed. The market analysis is based on both the technical and economic data developed by the project.

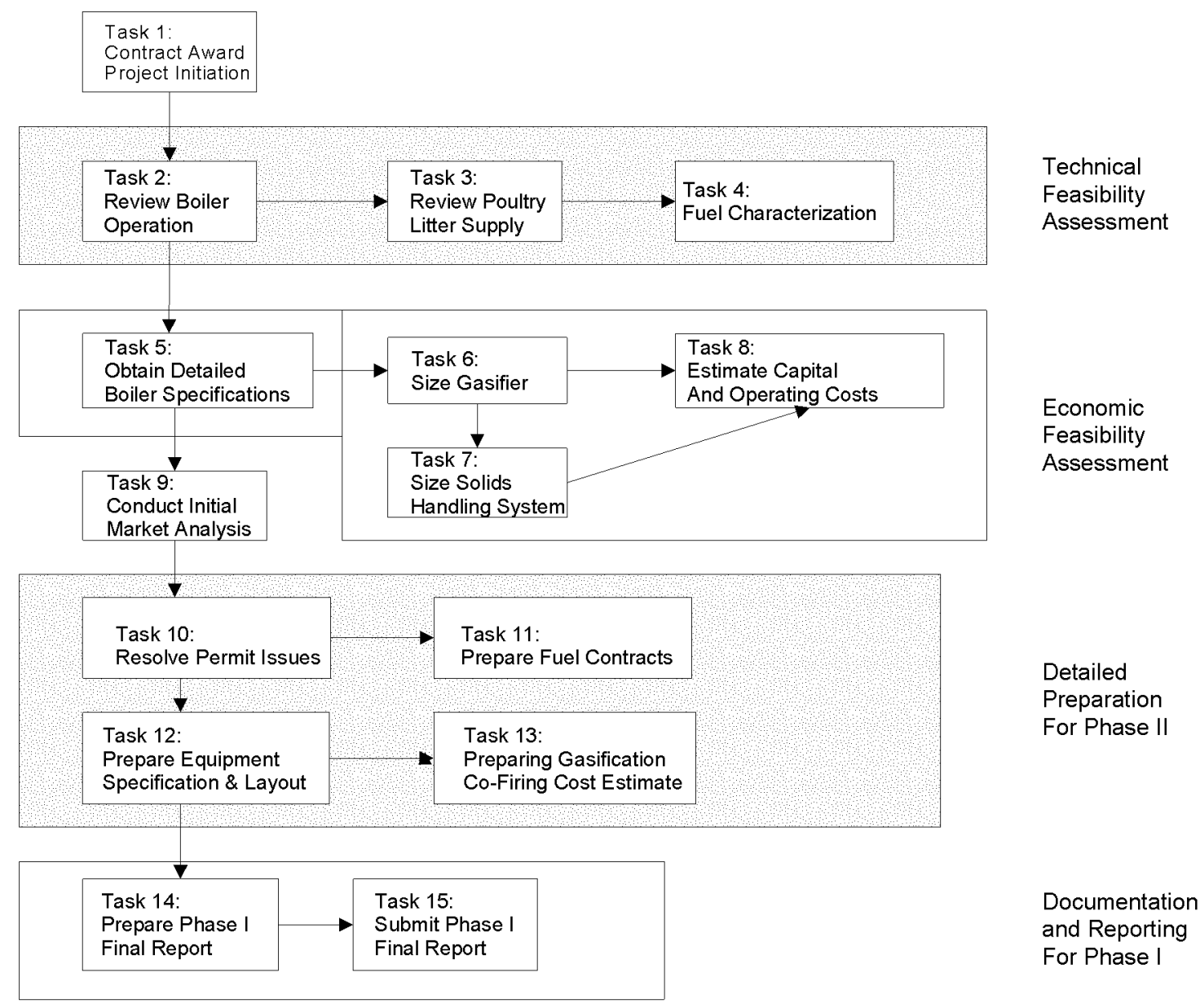

Figure 1-5 Interrelationships of Tasks in Phase I 


\section{Gasification Based Biomass Cofiring, Phase I DOE NETL Project DE-FC26-00NT40898}

The schedule for the proposed tasks is shown in 1-6.

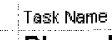

Phase I Complete

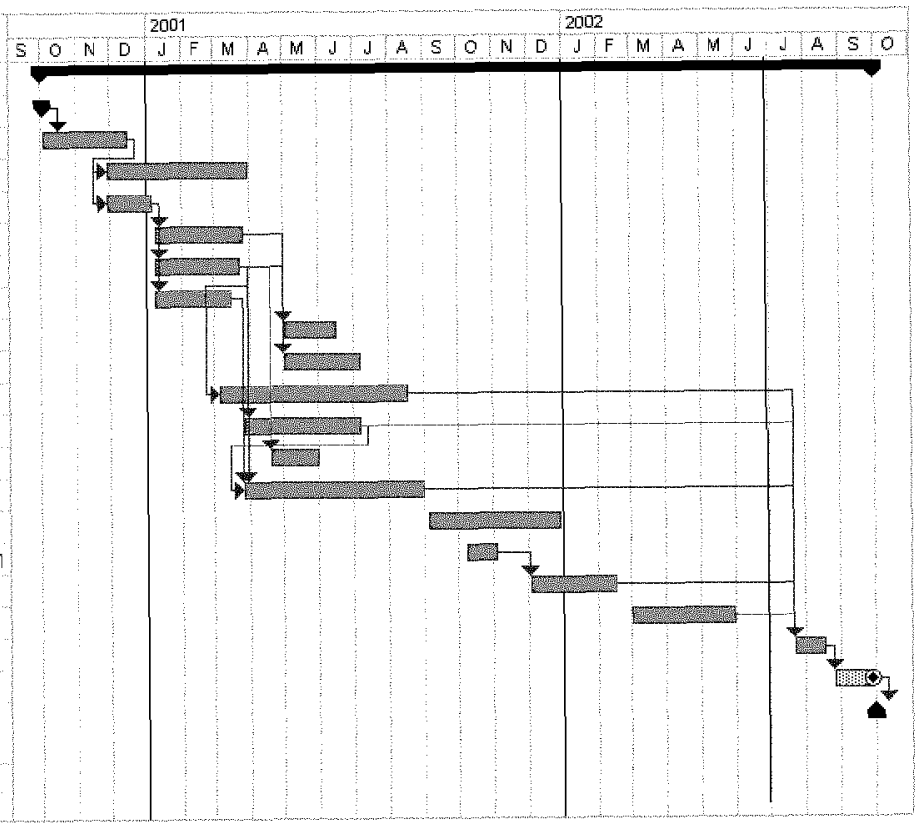

Figure 1-6 Project Milestone Schedule 


\section{Technology Evaluation}

Understanding the gasification approach to co-firing requires a review of the current status of co-firing, the issues raised and the lessons learned, and the consequent market position of direct combustion co-firing. Identifying how gasification addresses the unresolved issues of direct combustion co-firing facilitates this understanding.

\subsection{Overview of Co-firing Technologies}

There are two principal co-firing technologies that have been tested in the power plant boilers with some success. But long-term continuous co-firing has not been adopted due to unresolved issues identified in Section 2.2.

\subsubsection{Low Percentage Co-firing:}

Low percentage co-firing is typically designated as blending $<5$ percent biomass (mass basis) with coal as primary fuel for the boiler. The biomass component is typically $<2$ percent of the heat input to the boiler.

There have been several low percentage co-firing tests and demonstrations, including the following:

- Colbert Fossil Plant, TVA

- Shawville Generating Station, GPU Genco

- Kingston Fossil Plant, TVA

- Plant Hammond, Georgia Power Co.

- Plant Yates, Georgia Power Co.

These tests and demonstrations provided critical results for co-firing. They demonstrated that co-firing at low percentages does not impact boiler stability, operability, or efficiency. Further, it does not impact airborne emissions.

\subsubsection{Direct Combustion Co-firing with Separate Feed Systems}

There have been several demonstrations of co-firing using separate feeding of biomass into the boiler. In these demonstrations the biomass is reduced in particle size to an acceptable level (typically $6 \mathrm{~mm}$ or $<1 / 4$ " for wood waste) and then pneumatically transported into burner systems of the boiler. In these systems, biomass typically supplies about 5 to 10 percent of the heat input to the boiler, or 10 to 20 percent of the mass input of fuel to the boiler. This approach has been tested by co-firing with wood waste and with processed switch grass at following facilities:

- Seward Generating Station, GPU Generating Co (wood waste) 
- Greenidge Station, NYSEG (wood waste)

- Plant Kraft, Savannah Electric (wood waste)

- Blount St. Station, Madison Gas \& Electric (switch grass)

These tests all documented the fact that if separate feeding were employed and if there was no impact on the coal delivery system, boiler capacity would not be impaired by co-firing. In cases where biomass was substituted for coal in coal burners, capacity impacts did occur as a consequence of substituting a low Btu fuel for a high Btu fuel. However, in most cases the biomass injection was independent of the coal injection. Co-firing provided capacity assistance, particularly in conditions where wet coal was being burned. Particle size becomes a concern. Wood waste particles must be $<6 \mathrm{~mm}(<1 / 4 ")$ while switch grass must undergo maximum particle size reduction to achieve acceptable minor dimension values. Concerns are both for the kinetics of combustion and the aerodynamic properties of the fuel, keeping the fuel from simply falling in to the bottom ash pit.

While co-firing with separate feeding resolved the capacity issue, it provided additional benefits as well as concerns. Boiler efficiencies were reduced modestly, based upon the moisture in the fuel and the hydrogen content of the fuel. When co-firing at 10 percent by heat input, there was no need to increase the excess air to the system, and there was no increase in the air heater exit temperature. Unburned carbon increases were modest, and statistically insignificant. Emissions were reduced. $\mathrm{SO}_{2}$ emissions were reduced as a function of co-firing a sulfur-free fuel. NOx, emissions were reduced consistently in wall-fired PC boilers and in cyclone boilers; the data on these emissions are not as consistent in tangentially fired PC boilers. Opacity emissions improved in some cases, but not in others.

\subsubsection{Issues remaining to be resolved with co-firing}

The low percentage co-firing tests identified two issues: pulverizer capacity and ash management. When the capacity of a boiler is limited by the capacity of the pulverizers, co-firing can have significant impacts on overall system capacity. Ball and race mills experienced increased feeder speeds and increased amps and power consumption. Bowl mills experience decreased mill outlet temperatures and increased amps. A 3 percent co-firing level can decrease capacity by as much as 6 to 8 percent when pulverizer limitations are severe. When co-firing is practiced, the biomass fly ash is commingled with the coal fly ash. While many types of biomass are very low in ash, some are not. Further, there is a definitional issue with respect to ASTM Specification C-618, the pozzolan specification. That document clearly defines fly ash as coal fly ash. While the history of that specification includes considerations for excluding municipal waste fly ash from use in concrete mixtures, the consequence is to prevent the sale of any co-firing or biomass firing fly ash in concrete mixtures. 
Co-firing that uses separate injection and direct combustion does avoid the fuel feed system limitations but does not address the issue of commingled ash. Consequently, for plants selling fly ash, the high-end concrete market may remain unavailable.

\subsection{Gasification Technologies}

Direct combustion does not represent the only method of co-firing biomass with an existing fuel. Biomass can be gasified to produce a combustible gaseous product that can also be used in existing boilers.

Biomass gasification and pyrolysis is a technology that has existed for over 100 years. Research into this technology was particularly active in the 1920's and 1930 's, when the use of biomass for vehicular travel was being pursued. With the advent of low cost oil and natural gas, interest in biomass gasification waned. However, with the dramatic oil price shocks of the 1970's and with subsequent environmental pressures, interest in biomass gasification has become substantial and several new projects have been put forward for funding and financing.

The principles of thermal gasification for biomass have been well established. The reaction sequences include fuel-drying, pyrolysis to produce gaseous compounds and chars, and reactions of those gaseous compounds and chars to form the producer gas product. Pyrolysis of biomass is the degeneration of cellulous, lignin and the other biomass building blocks that produces a full range of compounds ranging from hydrogen and methane to long chain condensable hydrocarbons, commonly referred to as tars. Secondary reactions include the steam-carbon reaction producing $\mathrm{CO}$ and $\mathrm{H}_{2}$ from the char (eq. 2-1), the water-gas shift reaction to increase the $\mathrm{H}_{2}$ content in the gas (eq. 2-2), and the Boudouard reaction generating $\mathrm{CO}$ from the char and the $\mathrm{CO}_{2}$ in the product gas (eq. 2-3).

$$
\begin{aligned}
& \mathrm{C}+\mathrm{H}_{2} \mathrm{O} \Leftrightarrow \mathrm{CO}+\mathrm{H}_{2} \\
& \mathrm{CO}+\mathrm{H}_{2} \mathrm{O} \Leftrightarrow \mathrm{H}_{2}+\mathrm{CO}_{2} \\
& \mathrm{CO}_{2}+\mathrm{C} \Leftrightarrow 2 \mathrm{CO}
\end{aligned}
$$

The tars formed typically begin to condense out of the gas at about $425^{\circ} \mathrm{C}$ $\left(800^{\circ} \mathrm{F}\right)$. To prevent this, the gas can be maintained at elevated temperatures so the tars can be combusted with the gas, cracked into non-condensable components by passing the tar laden gas over a catalyst at elevated temperatures, or scrubbed out of the gas.

Most of the char is combusted in the gasifier system to provide heat for the pyrolysis. Any char not completely converted to gas is usually discharged with 
the ash products. Inorganic matter (e.g., potassium in the ash) may remain in the solid phase or may exit with the gas in the vapor phase.

Pyrolysis takes place without the presence of free oxygen, i.e. air; while gasification is done under sub-stochiometric conditions, with less than required amount of oxygen for complete combustion. The use of air will dictate the heating value of the product gas. Pyrolysis of biomass in the absence of air will provide a medium calorific value gas while air blown gasification systems will provide a low calorific value gas. If air is present, the ratio of free oxygen input to biomass feed is typically around 0.30 .

The simplest air gasifier is the updraft (counter flow) gasifier, in which air is introduced to the biomass through grates in the bottom of the furnace. Rather high temperatures are generated initially where the air first contacts the char, but the combustion gases immediately enter a zone of excess char, where any $\mathrm{CO} 2$ or $\mathrm{H} 20$ present is reduced to $\mathrm{CO}$ and $\mathrm{H}_{2}$ by the excess carbon. As the gases rise to lower temperature zones, they meet the descending biomass and pyrolyze the mass in the range of $205^{\circ} \mathrm{C}\left(400^{\circ} \mathrm{F}\right)$ to $480^{\circ} \mathrm{C}\left(900^{\circ} \mathrm{F}\right)$. Continuing to rise, they contact wet, incoming biomass and dry it. The counter flow of gas and biomass exchanges heat so that the gases exit at low temperatures.

Simplicity is a major advantage of these systems, and countercurrent gasification has long been employed both for biomass and coal. The original Lurgi gasification system is an updraft gasifier. However, the updraft gasifier has several drawbacks. First, the gasification zones, while maximizing mass transfer, also produce a gas sufficiently low in temperature to contain a wide variety of chemicals, tars, and oils that are generated in the pyrolysis zone. Because of the low gasifier exit temperatures, these contaminants can be allowed to condense in cooler regions of the gasifier exhaust pathway designed for this purpose, before the producer gas is transferred for co-firing in the boiler.

Alternatively, the producer gas can be partially oxidized to elevate its temperature above the tar condensation limit. For this reason, this gas is generally used in the "close-coupled" mode in which it is mixed immediately with air and a portion burned completely to $\mathrm{CO}_{2}$ and $\mathrm{H}_{2} \mathrm{O}$. The close-coupled mode is quite suitable for supplying a biomass gas to existing coal, oil or gas furnaces. The higher temperature at the gasifier grate may melt the ash and produce slagging on the grates with feedstock such as rice hulls and corncobs.

Primenergy, of Tulsa, OK, currently is a leading supplier of updraft or countercurrent gasifiers. Their technology has been applied to a wide variety of biomass including wood waste, rice hulls, switch grass, and other biomass feedstocks. These types of gasifiers have been installed in a variety of applications throughout the world, including a significant number of cogeneration applications. Initial gasification runs using poultry litter in the Primenergy gasifier indicates that these environmental and operating issues can be controlled to 
acceptable levels, but this performance needs to be verified for the conditions when the gasifier is coupled with existing boiler and can be tested.

The process proposed for this application is an air blown gasification. In this system, coarse biomass is processed in a thermal gasifier, with the product gas being fired in a boiler. The gas will be unconditioned and fired at elevated temperatures $540^{\circ} \mathrm{C}-875^{\circ} \mathrm{C}$ (e.g., $1,000^{\circ} \mathrm{F}-1,600^{\circ} \mathrm{F}$ ). If conditioning is required, the gas may be cleaned and partially quenched prior to use.

When this technique is used in coal-fired boilers, separate gas burners are required. Similarly, if this technique were used in natural gas-fired boilers, separate burners designed for low Btu gas would be necessary. Air-fuel ratios for natural gas combustion and for low Btu gas combustion are sufficiently different, and gas volumes are different, to make this adjustment necessary.

Gasification-based co-firing has not been widely practiced. However it is the basis for this proposed activity.

\subsection{Hot Gas Filtration System}

Hot-gas cleanup and filtration technologies play an important role in the gasification process. The main difference between hot gas cleanup systems (HGCUs) and conventional particulate removal technologies (ESP and baghouses) is that $\mathrm{HGCUs}$ operate at higher temperatures $\left(500\right.$ to $\left.1,000^{\circ} \mathrm{C}\right)$ and pressures ( 1 to $2 \mathrm{MPa}$ ), which eliminates the need for cooling of the gas.

HGCU technologies include ceramic candle filters, ceramic cross-flow filters, screenless granular-bed filters, acoustic agglomerators and hot electrostatic precipitators.

In a ceramic candle filter system, the hot gases from the gasifier flows from the outside of the candle to inside. The particulates are collected on the outside surface of the candles, and the clean gas flows to the top of the pressure vessel and the stack through the gas outlet. Periodic cleaning of the candles is done by injecting nitrogen or other inert gases from the blowback air reservoir.

Typical HGCUs can meet up to 99.9 percent removal efficiency of particulates larger than 10 microns.

\subsection{Environmental Impact of Gasification}

The greenhouse gases, primarily carbon dioxide, $(\mathrm{CO} 2)$, methane $(\mathrm{CH} 4)$, and pollutants namely nitrous oxide (NOx), sulfur dioxide (SO2) and particulates which are associated with industrial and agricultural activities, affect earth's environment and have significant impact on the climate. Table 2-1 shows 
selected greenhouse gasses that have been present in Earth's atmosphere due to both natural and human activities prior to pre-industrial period and the current period. $^{3}$

Table 2-1 Selected Greenhouse Gases Prior to 1850 v/s 1994

\begin{tabular}{|l|c|c|c|}
\hline & $\begin{array}{c}\text { Carbon } \\
\text { Dioxide }\end{array}$ & Methane & Nitrous Oxide \\
\hline $\begin{array}{l}\text { Pre Industrial } \\
\begin{array}{l}\text { Concentration } \\
\text { (Prior to 1850) }\end{array}\end{array}$ & $278 \mathrm{ppmv}$ & $700 \mathrm{ppbv}$ & $275 \mathrm{ppbv}$ \\
\hline Concentration in 1994 & $358 \mathrm{ppmv}$ & $1720 \mathrm{ppbv}$ & $312 \mathrm{ppbv}$ \\
\hline $\begin{array}{l}\% \text { Change from Pre- } \\
\text { industrial times }\end{array}$ & $29 \%$ & $146 \%$ & $13 \%$ \\
\hline
\end{tabular}

One way to reduce these green house gases is to displace some of the carbon that is now emitted to the atmosphere from the combustion of fossil fuels with carbon derived from renewable resources. No new net atmospheric buildup of $\mathrm{CO}_{2}$ or methane occurs in biomass combustion when the biomass is grown on a sustainable basis, because the released carbon dioxide is largely compensated by the amount of carbon dioxide withdrawn from the atmosphere during photosynthesis in the growth cycle.

Table 2-1 shows that the global average methane concentration in 1994 has more than doubled since pre-industrial times. One source of methane is from anaerobic decomposition of organic material in livestock and poultry manure. The reduction of methane released to the atmosphere can be achieved by installing recovery systems that extract methane as a fuel from the anaerobic digestion of liquid manure, but it is profitable only for large farms in warm climates where anaerobic processes can be more readily sustained.

Alternatively, this manure can be converted in a gasification system to recover useful energy and, at the same time, reduce methane emissions.

The poultry litter has been gasified and tested for emission by Primenergy at their Tulsa, OK commercial size test facilities in accordance with US EPA standards.

The unabated test data collected during the demonstration testing are presented here in Table 2-2 for evaluation. ${ }^{4}$ The test was conducted on the stack after burning the producer gas from the gasifier in the heat recovery steam generator. This data were collected by a third party stack testing outfit for Primenergy.

As shown in the table, the gasification process can be used to reduce the amount of greenhouse gases and other pollutants that result from decaying biomass while producing useful thermal energy and displacing the fossil fuel. 
Table 2-2 Unabated Emissions Data for Poultry Litter Test Gasification Run

\begin{tabular}{|l|l|}
\hline Component & Value \\
\hline $\mathrm{NO}$, ppmvd & 477 \\
$\mathrm{CO}$, ppmvd & 0.88 \\
$\mathrm{SO}_{2}$, ppmvd & 193 \\
Non-methane hydrocarbons, ppmvd & 2.46 \\
Particulate matter, gr/dscf & 0.33 \\
$\mathrm{O}_{2}$, ppm dry volume & 11.5 \\
\hline
\end{tabular}

Source: CETCON, INC. "Summary of Results: Test No. C1", September $15,1997$.

Under cofiring, application, the litter can be used to reduce other pollutants from the coal plant by reducing the amount of coal burned. The following table 2-3 provides a comparison between the coal plant emissions and expected emissions from gasification and controlled combustion of the producer gas in a boiler.

\subsubsection{Comparison of Coal v/s Litter Burn}

Typical coal and litter samples and expected emissions from the two sources can be estimated. In estimating the emissions presented in Table 2-3, following assumptions are made:

- $\mathrm{S}$ in coal is elemental $\mathrm{S}$ and hence ends up as $\mathrm{SO}_{2}$ in complete oxidizing environment normally present in a coal fired boiler. $S$ in the litter is compound $S$ and as such, some of it remains in the ash as Alkaline sulfates. Hence, the calculated $1.02 \mathrm{~kg} / \mathrm{MJ}\left(2.14 \mathrm{lbs} / \mathrm{MMBtu}^{\mathrm{SO}} \mathrm{O}_{2}\right)$ is high end $\mathrm{SO}_{2}$ when gasifying litter. It is expected that may be $50 \%$ of the $\mathrm{S}$ will remain in the ash, as evident from elemental analysis of ash with $4 \% \mathrm{SO}_{3}$ in the ash. Thus, litter gasification in a cofiring application can reduce $\mathrm{SO}_{2}$ from high sulfur burning coal plant.

- On GJ (MMBtu) basis, carbon is about the same in litter and coal, and hence $\mathrm{CO}_{2}$ emissions from litter or coal are a wash. However, from life cycle perspective, $\mathrm{CO}_{2}$ / Carbon is considered closed loop for biomass, and hence no new net $\mathrm{CO}_{2}$ is introduced in to atmosphere from the chicken/ litter cycle.

- $\mathrm{N}$ in the coal is elemental $\mathrm{N}$ and all NOx produced is thermal NOx due to combustion in the air. Litter has high bound nitrogen that is gasified into amines, amines, urea, etc. If burned in regular boiler in an oxidizing atmosphere, it will generate very high NOx - as much as 2000 ppm. But by external after burn in a reducing atmosphere, the amines, amines, 
urea, etc. are broken down into elemental $\mathrm{N}$ and water/CO2. Primenergy expects NOx from gasifier to be less than $0.40 \mathrm{lbs} / \mathrm{MMBtu}$.

- Gasifier will generate about 4 times the ash on MMBtu basis. However, this is organic ash - with high $\mathrm{P}$ and $\mathrm{K}$ compound and as such has good value as fertilizer as well as supplement to animal feed. We are investigating after market for the ash to offset the cost of acquiring the litter.

- Litter does not have any detectable level of heavy metals, such as $\mathrm{Hg}$, As, $\mathrm{Pb}, \mathrm{Cd}$, etc. Hence, there will not be any detectable level of these heavy metals in the gasifier producer gas.

Table 2-3 Coal and litter composition and expected emissions

\begin{tabular}{|c|c|c|c|c|c|}
\hline Coal & $\begin{array}{l}\text { per kG } \\
\text { (per Ib) }\end{array}$ & $\begin{array}{c}\text { kg/MJ } \\
\text { (Ibs/MMBtu) }\end{array}$ & $\begin{array}{c}\text { Expected } \\
\text { Combustion } \\
\text { Products }\end{array}$ & $\begin{array}{c}\text { kg/MJ } \\
\text { (Ibs/MMBtu) }\end{array}$ & Comments \\
\hline LHv kJ/kg (Btu/lbs) & $\begin{array}{c}11,826 \\
(11,200)\end{array}$ & - & & - & \\
\hline S & $\begin{array}{c}0.01 \\
(0.03)\end{array}$ & $\begin{array}{c}0.96 \\
(2.23)\end{array}$ & $\mathrm{SO}_{2}$ & $\begin{array}{c}1.92 \\
(4.46)\end{array}$ & \\
\hline C & $\begin{array}{c}0.29 \\
(0.64)\end{array}$ & $\begin{array}{c}24.38 \\
(56.72)\end{array}$ & $\mathrm{CO}_{2}$ & $\begin{array}{c}89.39 \\
(207.99)\end{array}$ & \\
\hline $\mathrm{H}$ & $\begin{array}{c}0.02 \\
(0.05)\end{array}$ & $\begin{array}{c}1.73 \\
(4.02)\end{array}$ & $\mathrm{H}_{2} \mathrm{O}$ & $\begin{array}{c}15.55 \\
(36.16)\end{array}$ & \\
\hline$N$ & $\begin{array}{c}0.01 \\
(0.02)\end{array}$ & $\begin{array}{c}0.58 \\
(1.29)\end{array}$ & NOx & $\begin{array}{l}0.34 \\
(0.78)\end{array}$ & (as reported) \\
\hline Ash & $\begin{array}{l}0.05 \\
(0.12)\end{array}$ & $\begin{array}{c}4.57 \\
(10.63)\end{array}$ & Ash & $\begin{array}{c}4.57 \\
(10.63)\end{array}$ & \\
\hline \multicolumn{6}{|l|}{ Litter } \\
\hline LHv kJ/kg (Btu/lbs) & $\begin{array}{c}4,435 \\
(4,200)\end{array}$ & & & & \\
\hline s & $\begin{array}{c}0.00 \\
(0.01)\end{array}$ & $\begin{array}{c}0.51 \\
(1.07)\end{array}$ & $\mathrm{SO}_{2}$ & $\begin{array}{c}0.60 \sim 1.02 \\
(1.25 \sim 2.14)\end{array}$ & $\begin{array}{l}\text { Calculated Assuming } \\
50 \% \text { remain in ash }\end{array}$ \\
\hline c & $\begin{array}{c}0.11 \\
(0.25)\end{array}$ & $\begin{array}{c}25.18 \\
(58.57)\end{array}$ & $\mathrm{CO}_{2}$ & $\begin{array}{c}92.34 \\
(214.76)\end{array}$ & \\
\hline $\mathrm{H}$ & $\begin{array}{l}0.01 \\
(0.03)\end{array}$ & $\begin{array}{l}2.76 \\
(6.52)\end{array}$ & $\mathrm{H}_{2} \mathrm{O}$ & $\begin{array}{l}24.88 \\
(58.71)\end{array}$ & \\
\hline $\mathrm{N}$ & $\begin{array}{l}0.01 \\
(0.03)\end{array}$ & $\begin{array}{l}2.56 \\
(5.95)\end{array}$ & NOx & $\begin{array}{c}0.17 \\
(0.36 \sim 0.40)\end{array}$ & Estimate -after burn \\
\hline Ash & $\begin{array}{l}0.09 \\
(0.19)\end{array}$ & $\begin{array}{c}19.66 \\
(45.71)\end{array}$ & Ash & $\begin{array}{c}19.66 \\
(45.71)\end{array}$ & \\
\hline
\end{tabular}

From Table 2-3, it is evident that the biomass offers a unique opportunity in energy production, with benefits of life cycle reduction in carbon dioxide and better management of methane from the agricultural waste. 


\section{Project Evaluation}

\subsection{WKE Case}

\subsubsection{WKE Reid Plant}

The WKE's Reid plant is located near Henderson, Kentucky. It is a $63 \mathrm{MWe}$ coal-fired unit with a pulverized coal-fired Riley Stoker boiler. The boiler uses Western Kentucky coal. The boiler has maximum continuous capacity (MCR) of $690,000 \mathrm{lbs} . / \mathrm{hr}$ of steam at $1300 \mathrm{psig}$ and $955 \mathrm{deg}$. F.

Detailed Specifications of the boiler vendor and a boiler schematic (Figure 3-1) are provided here.

\section{Reid Plant Boiler Specification by Riley Stocker Co. ${ }^{5}$}

Location

WKE Contract

RILEY Boiler Contract No

RILEY Fuel Burning Contract No

RILEY Boiler Serial No

Year Built

Rating based on burning specification coal

Maximum Continuous Steam Capacity (MCR)

Peak Steam Capacity, (for four hrs.)

Type of Furnace Operation

Drum Design Pressure

Economizer design Pressure

Operating Pressure at Super heater Outlet

Steam, Temperature at Superheater Outlet

Furnace Volume

Heat Release (at 690,000 lbs./hr. capacity)

Heat Release (at 760,000 lbs./hr. capacity)

Heating Surfaces (Per Manufacturer's Stamping Sheet)

Boiler

Water Walls

Superheater

Economizer

Air Heater

Approximate Water Capacity To Normal Water Level Approximate Water Capacity For Hydrostatic Test
Henderson Co. KY

B2502

B2502

TM6833.

3456

1964

$690,000 \mathrm{lbs} . / \mathrm{hr}$

$760,000 \mathrm{lbs} . / \mathrm{hr}$

Pressurized

1475 psig

1525 psig

1300 psig

$955^{\circ} \mathrm{F}$

50,250 cuft

$16,600 \mathrm{Btu} / \mathrm{cuft} / \mathrm{hr}$

19,400 Btu/cuft/hr

4,020 sq. ft

12,100 sq. ft

32,330 sq. $\mathrm{ft}$

4,200 sq. $\mathrm{ft}$

82,400 sq. ft

$500,788 \mathrm{lbs}$.

$827,253 \mathrm{lbs}$. 


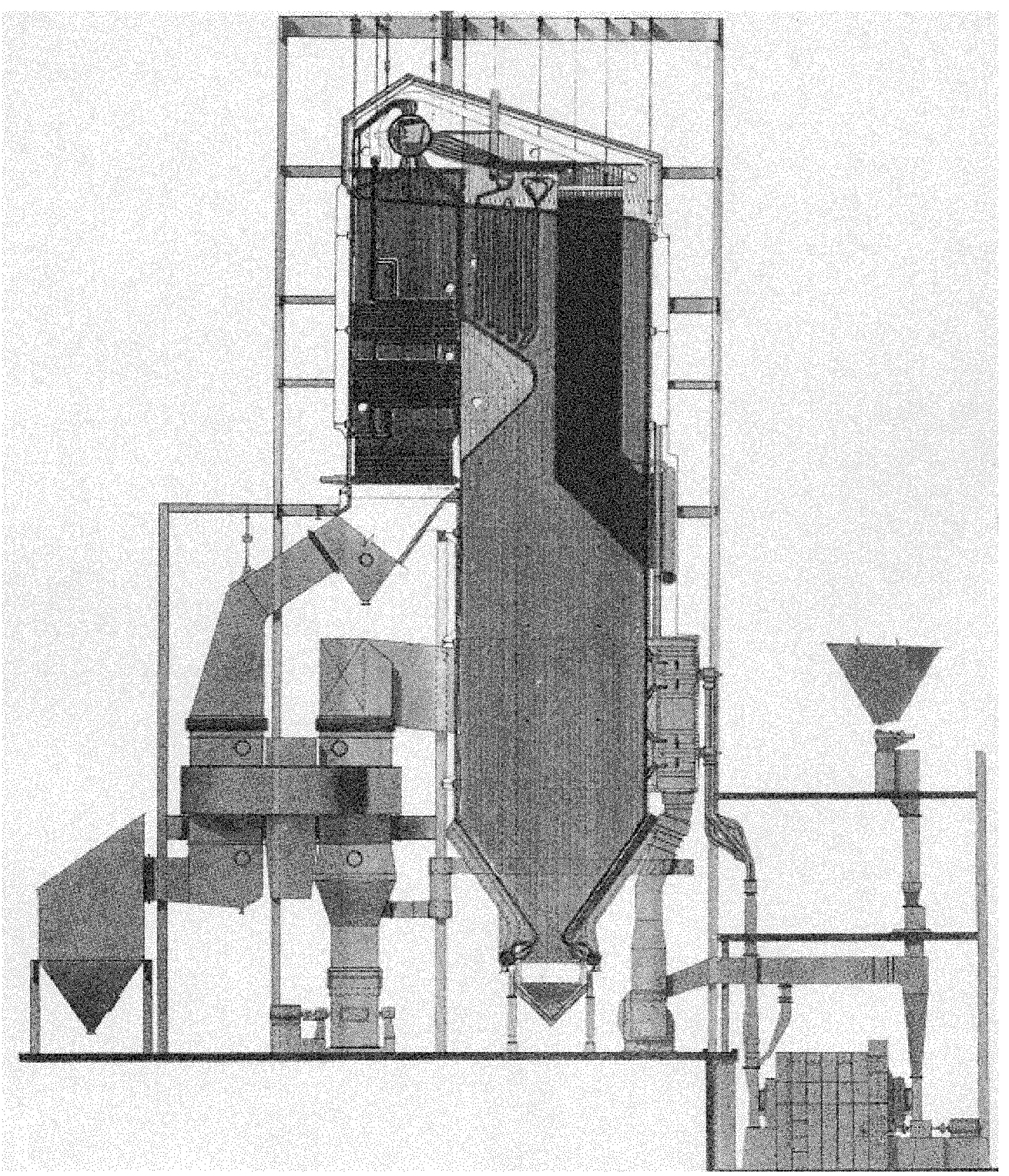

Figure 3-1 Reid Plant Boiler Schematic

$690,000 \mathrm{lbs} / \mathrm{hr}-1475 \mathrm{psig}$ design pressure, $1300 \mathrm{psig}$ operating pressure 955 F Steam, Fuel: Kentucky Coal 


\subsubsection{Reid Plant Boiler Data}

\section{Boiler Operating Data}

The boiler operating data at $50 \%$ and at $100 \%$ plant load when burning coal were obtained from the plant. Table 3-1 list the summary of the boiler operating data.

Table 3-1 Reid Plant Boiler Operating Data

\begin{tabular}{|c|c|c|c|c|c|c|c|c|}
\hline Power & $\begin{array}{c}\text { FD Fan } \\
\text { Dish } \\
\text { Pres } \\
\end{array}$ & $\begin{array}{c}\text { Furnace } \\
\text { Press }\end{array}$ & $\begin{array}{c}\text { Windbox } \\
\text { Press }\end{array}$ & $\begin{array}{c}\text { Sec SH } \\
\text { Gas } \\
\text { Press }\end{array}$ & $\begin{array}{c}\text { Primary } \\
\text { SH Gas } \\
\text { Press }\end{array}$ & $\begin{array}{c}\text { Air Flow } \\
\text { lbs/hr }\end{array}$ & $\begin{array}{c}\text { Econ } \\
\text { Gas } \\
\text { Temp } \\
\end{array}$ & $\begin{array}{c}\text { Excess } \\
\mathrm{O} 2 \\
\end{array}$ \\
\hline MW & $\begin{array}{c}\mathrm{Pa} \\
(" \mathrm{H} 2 \mathrm{O})\end{array}$ & $\begin{array}{c}\mathrm{Pa} \\
(" \mathrm{H} 2 \mathrm{O})\end{array}$ & $\begin{array}{c}\mathrm{Pa} \\
(" \mathrm{H} 2 \mathrm{O})\end{array}$ & $\begin{array}{c}\mathrm{Pa} \\
(" \mathrm{H} 2 \mathrm{O})\end{array}$ & $\begin{array}{c}\mathrm{Pa} \\
(" \mathrm{H} 2 \mathrm{O})\end{array}$ & $\begin{array}{c}\mathrm{kg} / \mathrm{h} \mathrm{x} \\
(\mathrm{Lbs} / \mathrm{hr} \mathrm{x}) \\
10^{\wedge} 3\end{array}$ & $\begin{array}{c}\operatorname{Deg} C \\
(\operatorname{Deg} F)\end{array}$ & $\%$ \\
\hline 36 & $\begin{array}{c}22.1 \\
(9)\end{array}$ & $\begin{array}{c}9.84 \\
(4)\end{array}$ & $\begin{array}{c}17.22 \\
(7)\end{array}$ & $\begin{array}{c}9.84 \\
(4)\end{array}$ & $\begin{array}{c}8.6 \\
(3.5) \\
\end{array}$ & $\begin{array}{c}195 \\
(430) \\
\end{array}$ & $\begin{array}{c}217 \\
(423) \\
\end{array}$ & 4.4 \\
\hline 37 & $\begin{array}{l}23.4 \\
(9.5)\end{array}$ & $\begin{array}{c}9.84 \\
(4)\end{array}$ & $\begin{array}{l}18.45 \\
(7.5)\end{array}$ & $\begin{array}{l}10.6 \\
(4.3)\end{array}$ & $\begin{array}{c}7.9 \\
(3.2)\end{array}$ & $\begin{array}{c}195 \\
(430)\end{array}$ & $\begin{array}{c}218 \\
(425)\end{array}$ & 6 \\
\hline 35 & $\begin{array}{l}23.4 \\
(9.5)\end{array}$ & $\begin{array}{c}9.84 \\
(4)\end{array}$ & $\begin{array}{l}18.45 \\
(7.5)\end{array}$ & $\begin{array}{l}10.3 \\
(4.2)\end{array}$ & $\begin{array}{c}7.9 \\
(3.2)\end{array}$ & $\begin{array}{c}199 \\
(439)\end{array}$ & $\begin{array}{c}221 \\
(430)\end{array}$ & 6 \\
\hline 60 & $\begin{array}{l}29.5 \\
(12)\end{array}$ & $\begin{array}{c}14.8 \\
(6)\end{array}$ & $\begin{array}{c}22.1 \\
(9)\end{array}$ & $\begin{array}{l}15.7 \\
(6.4)\end{array}$ & $\begin{array}{l}12.3 \\
(5)\end{array}$ & $\begin{array}{c}278 \\
(613)\end{array}$ & $\begin{array}{c}241 \\
(465)\end{array}$ & 2.8 \\
\hline 61 & $\begin{array}{c}30.8 \\
(12.5)\end{array}$ & $\begin{array}{c}16 \\
(6.5)\end{array}$ & $\begin{array}{l}23.4 \\
(9.5)\end{array}$ & $\begin{array}{c}16 \\
(6.5)\end{array}$ & $\begin{array}{c}13 \\
(5.3)\end{array}$ & $\begin{array}{c}295 \\
(651)\end{array}$ & $\begin{array}{c}243 \\
(469)\end{array}$ & 2.9 \\
\hline 61 & $\begin{array}{c}30.8 \\
(12.5)\end{array}$ & $\begin{array}{l}15.3 \\
(6.2) \\
\end{array}$ & $\begin{array}{c}22.1 \\
(9)\end{array}$ & $\begin{array}{c}16 \\
(6.5) \\
\end{array}$ & $\begin{array}{l}12.8 \\
(5.2) \\
\end{array}$ & $\begin{array}{c}293 \\
(645) \\
\end{array}$ & $\begin{array}{c}238 \\
(460) \\
\end{array}$ & 2.4 \\
\hline 62 & $\begin{array}{l}32.0 \\
(13)\end{array}$ & $\begin{array}{c}16 \\
(6.5)\end{array}$ & $\begin{array}{l}23.4 \\
(9.5)\end{array}$ & $\begin{array}{l}16.7 \\
(6.8)\end{array}$ & $\begin{array}{l}13.5 \\
(5.5)\end{array}$ & $\begin{array}{c}304 \\
(670)\end{array}$ & $\begin{array}{c}247 \\
(476)\end{array}$ & 2.8 \\
\hline
\end{tabular}

\subsubsection{Gasifier Material and Energy Balance}

After reviewing the available poultry litter supply in the vicinity of the Reid Plant, the gasifier for the Reid plant study is sized for $7.5 \mathrm{t} / \mathrm{h}$ (8.4-ton/hr) capacity. This is a one single $\mathrm{KC}-18$ gasifier. Material and energy balance for the $\mathrm{KC}-18$ has been prepared and a summary of it is attached with detailed balance in the Appendix of this report. The gasifier will be located on south side of the Reid plant, underneath the coal conveyor belt. Layout drawings of the gasifier and fuel silos are provided in the Appendix.

The following two tables, table 3-2 and table 3-3 provides material and energy balance for specific streams. Refer to the stream number in the process flow diagram provided in the Appendix A for the WKE case. The detailed material and energy balance for each stream in the PFD is also provided in Table A-2 in the Appendix A. 
Table 3-2 Material Balance for the Gasifier

\begin{tabular}{|c|c|c|c|c|c|c|c|}
\hline Selected Stream & 1 & 2 & 3 & 4 & 7 & 8 & 11 \\
\hline Name & GASIFIER & GASIFIER & GASIFIER & GASIFIER & HOT GAS & ID FAN & OVERFIRE \\
\hline & FEED & Comb Air & Bot. Ash & GAS & FILTER & EXHAUST & GAS \\
\hline Pressure, Pa ("w.c. -g) & $\begin{array}{l}-- \\
---\end{array}$ & $\begin{array}{l}-4.92 \\
(-20)\end{array}$ & $\begin{array}{l}-- \\
---\end{array}$ & $\begin{array}{l}-0.062 \\
(-0.25)\end{array}$ & $\begin{array}{l}-2.46 \\
(-10)\end{array}$ & $\begin{array}{c}1.97 \\
(8)\end{array}$ & $\begin{array}{c}1.72 \\
(7)\end{array}$ \\
\hline Temperature, ${ }^{\circ} \mathrm{C}\left({ }^{\circ} \mathrm{F}\right)$ & $\begin{array}{c}25 \\
(77)\end{array}$ & $\begin{array}{c}27 \\
(80)\end{array}$ & $\begin{array}{c}149 \\
(300)\end{array}$ & $\begin{array}{c}843 \\
(1,550)\end{array}$ & $\begin{array}{c}750 \\
(1,382)\end{array}$ & $\begin{array}{c}750 \\
(1,382)\end{array}$ & $\begin{array}{c}1,316 \\
(2,400)\end{array}$ \\
\hline $\begin{array}{c}\text { Molecular Weight } \mathrm{kg} / \mathrm{kg} \text { mole } \\
\text { or } \mathrm{lb} / \mathrm{lb} \text { mole }\end{array}$ & --- & 28.68 & 68.87 & 24.89 & 24.58 & 24.58 & 26.89 \\
\hline Component & $\mathrm{kg} / \mathrm{h}(\mathrm{lb} / \mathrm{h})$ & $\mathrm{kg} / \mathrm{h}(\mathrm{lb} / \mathrm{h})$ & $\mathrm{kg} / \mathrm{h}(\mathrm{lb} / \mathrm{h})$ & $\mathrm{kg} / \mathrm{h}(\mathrm{lb} / \mathrm{h})$ & $\mathrm{kg} / \mathrm{h}(\mathrm{lb} / \mathrm{h})$ & $\mathrm{kg} / \mathrm{h}(\mathrm{lb} / \mathrm{h})$ & $\mathrm{kg} / \mathrm{h}(\mathrm{lb} / \mathrm{h})$ \\
\hline Carbon & $\begin{array}{c}2080 \\
(4,582)\end{array}$ & & $\begin{array}{c}280 \\
(616)\end{array}$ & & & & \\
\hline Hydrogen & $\begin{array}{c}229 \\
(505)\end{array}$ & & & & & & \\
\hline Nitrogen & $\begin{array}{r}215 \\
(473)\end{array}$ & & & & & & \\
\hline Oxygen & $\begin{array}{c}1526 \\
(3,361)\end{array}$ & & & & & & \\
\hline Sulfur & $\begin{array}{c}36 \\
(80)\end{array}$ & & & & & & \\
\hline Carbon Monoxide & & & & $\begin{array}{c}1642 \\
(3617)\end{array}$ & $\begin{array}{c}1642 \\
(3617)\end{array}$ & $\begin{array}{l}1642 \\
(3617)\end{array}$ & $\begin{array}{l}270 \\
594\end{array}$ \\
\hline Carbon Dioxide & & & & $\begin{array}{c}4017 \\
(8847)\end{array}$ & $\begin{array}{c}4017 \\
(8847)\end{array}$ & $\begin{array}{c}4017 \\
(8847)\end{array}$ & $\begin{array}{c}6202 \\
(13644)\end{array}$ \\
\hline Hydrogen & & & & $\begin{array}{c}185 \\
(408)\end{array}$ & $\begin{array}{c}185 \\
(408)\end{array}$ & $\begin{array}{c}185 \\
(408)\end{array}$ & $\begin{array}{c}88 \\
(193)\end{array}$ \\
\hline Water (vapor) & & $\begin{array}{c}115 \\
(253)\end{array}$ & & $\begin{array}{c}2416 \\
(5322)\end{array}$ & $\begin{array}{c}2945 \\
(6486)\end{array}$ & $\begin{array}{l}2945 \\
(6486)\end{array}$ & $\begin{array}{c}3908 \\
(8608)\end{array}$ \\
\hline Nitrogen & & $\begin{array}{c}8982 \\
(19785)\end{array}$ & & $\begin{array}{c}9197 \\
(20257)\end{array}$ & $\begin{array}{c}9197 \\
(20257)\end{array}$ & $\begin{array}{c}9197 \\
(20257)\end{array}$ & $\begin{array}{c}14483 \\
(31900)\end{array}$ \\
\hline Oxygen & & $\begin{array}{r}2719 \\
(5989)\end{array}$ & & & & & \\
\hline Sulfur Dioxide & & & & $\begin{array}{c}73 \\
(160)\end{array}$ & $\begin{array}{c}73 \\
(160)\end{array}$ & $\begin{array}{c}73 \\
(160)\end{array}$ & \\
\hline Ash & $\begin{array}{c}1634 \\
(3599)\end{array}$ & & $\begin{array}{c}1914 \\
(4215)\end{array}$ & & & & \\
\hline Water (liquid) & $\begin{array}{c}1907 \\
(4200)\end{array}$ & & & & & & \\
\hline TOTAL & $\begin{array}{c}7627 \\
(16800)\end{array}$ & $\begin{array}{c}11816 \\
(26 \quad 028)\end{array}$ & $\begin{array}{c}2193 \\
(4 \text { 831) }\end{array}$ & $\begin{array}{c}17529 \\
(38720)\end{array}$ & $\begin{array}{c}18058 \\
(39776)\end{array}$ & $\begin{array}{c}18058 \\
(39776)\end{array}$ & $\begin{array}{c}24950 \\
(54956)\end{array}$ \\
\hline
\end{tabular}


Table 3-3 Energy Balance for the Gasifier

\begin{tabular}{|c|c|c|c|c|c|c|c|}
\hline Selected Stream & $\mathbf{1}$ & $\mathbf{2}$ & $\mathbf{3}$ & $\mathbf{4}$ & $\mathbf{7}$ & $\mathbf{8}$ & $\mathbf{1 1}$ \\
\hline Name & $\begin{array}{c}\text { GASIFIER } \\
\text { FEED }\end{array}$ & $\begin{array}{c}\text { GASIFIER } \\
\text { Comb Air }\end{array}$ & $\begin{array}{c}\text { GASIFIER } \\
\text { Bot. Ash }\end{array}$ & $\begin{array}{c}\text { GASIFIER } \\
\text { GAS }\end{array}$ & $\begin{array}{c}\text { HOT GAS } \\
\text { FILTER }\end{array}$ & $\begin{array}{c}\text { ID FAN } \\
\text { EXHAUST }\end{array}$ & $\begin{array}{c}\text { OVERFIRE } \\
\text { GAS }\end{array}$ \\
\hline TOTAL kg/h (Ibs/h) & $\begin{array}{c}7627 \\
(16800)\end{array}$ & $\begin{array}{c}11816 \\
(26028)\end{array}$ & $\begin{array}{c}2193 \\
(4831)\end{array}$ & $\begin{array}{c}17529 \\
(38720)\end{array}$ & $\begin{array}{c}18058 \\
(39776)\end{array}$ & $\begin{array}{c}18058 \\
(39776)\end{array}$ & $\begin{array}{c}24950 \\
(54956)\end{array}$ \\
\hline $\begin{array}{c}\text { Heat of Combustion LHV } \\
\text { kJ/kg (Btu/lb) }\end{array}$ & $\begin{array}{c}9567 \\
(4110)\end{array}$ & & & 2223 & 2165 & 2165 & 533 \\
$(955)$ & $(930)$ & $(930)$ & $(229)$ \\
\hline $\begin{array}{c}\text { Combustion Energy GJ/h } \\
\text { (MMBtu/h) }\end{array}$ & $\begin{array}{c}72.85 \\
(69)\end{array}$ & & & $\begin{array}{c}38.9 \\
(37)\end{array}$ & $\begin{array}{c}38.9 \\
(37)\end{array}$ & $\begin{array}{c}39.0 \\
(37)\end{array}$ & $\begin{array}{c}13.3 \\
(13)\end{array}$ \\
\hline $\begin{array}{c}\text { Thermal Energy GJ/h } \\
\text { (MMBtu/h) }\end{array}$ & -- & & $\begin{array}{c}20.7 \\
(19.6)\end{array}$ & $\begin{array}{c}20.7 \\
(19.6)\end{array}$ & $\begin{array}{c}19.25 \\
(18.25)\end{array}$ & $\begin{array}{c}46.3 \\
(43.9)\end{array}$ \\
\hline $\begin{array}{c}\text { Total Energy GJ/h } \\
\text { (MMBtu/h) }\end{array}$ & $\begin{array}{c}72.85 \\
(69)\end{array}$ & & $(-6.6)$ & $\begin{array}{c}59.6 \\
(56.6)\end{array}$ & $\begin{array}{c}59.6 \\
(56.6)\end{array}$ & $\begin{array}{c}60.4 \\
(57.25)\end{array}$ & $\begin{array}{c}60 \\
(56.9)\end{array}$ \\
\hline $\begin{array}{c}\text { FLOW RATE m3/s (scfm) } \\
\text { (M) }\end{array}$ & --- & $\begin{array}{c}2.73 \\
(5740)\end{array}$ & -- & $\begin{array}{c}4.65 \\
(9838)\end{array}$ & $\begin{array}{c}4.83 \\
(10235)\end{array}$ & $\begin{array}{c}4.83 \\
(10235)\end{array}$ & $\begin{array}{c}6.1 \\
(12928)\end{array}$ \\
\hline
\end{tabular}

The overall gasifier efficiency is estimated at $82.5 \%$ based on heat input from poultry litter and supplemental fuel in the over-fire gas $\mathrm{v} / \mathrm{s}$ heat energy out to the boiler from the producer gas.

The heat out put from the gasifier will vary based on the quality of the fuel and moisture content of the litter. For the design and equipment sizing, the numbers in the above tables are used.

\subsubsection{Gasifier Boiler Integration}

Babcock Borsig Power Inc. was contracted by the project to perform preliminary engineering study to determine

- Size and number of penetrations required for the flow of the producer gas from the gasifier into the boiler.

- Feasible locations for the penetrations in order to minimize the impact on the existing boiler equipment and boiler operations.

- Producer gas pressure requirements at the penetrations.

- Required stiffening and strengthening at the penetrations.

Details of BB Power findings and sizing criteria were provided in a separate report. ${ }^{6}$ The BB Power report is included in Appendix C. Following is the brief summary of the BB Power findings: 
- The biogas from the gasifier is burned at the over-fire combustion chamber located at the boiler penetration. The combustion takes place in a reducing atmosphere and the hot gases will be entering the boiler at $1320^{\circ} \mathrm{C}\left(2400^{\circ} \mathrm{F}\right)$.

- The gas flow provided by the gasifier is at $32.3 \mathrm{~m}^{3} / \mathrm{s}$ (79 350 ACFM).

- The gas pressure requirement at the penetrations is at a minimum of 1.72 $\mathrm{Pa}(+8$ "of W.C.).

- The selected velocity by BBPower at the boiler penetrations is $45.7 \mathrm{~m} / \mathrm{s}$ $(150 \mathrm{ft} / \mathrm{sec})$

- Four penetrations of $0.5 \mathrm{~m}$ (20 inch) inside diameter will meet the total flow cross sectional area requirements of $0.7 \mathrm{~m}^{2}\left(8.8 \mathrm{ft}^{2}\right)$.

- The designed locations for these penetrations are on the lower sidewalls of the furnace, two penetrations on each side, just below the bottom of the windbox level. The windbox and existing eight (8) burners are located at the front of the boiler.

- The furnace expansion at the location of the penetrations from the ambient rest position to the rated conditions is $108 \mathrm{~mm}$ (4.25 inch) downward at the bottom and $19 \mathrm{~mm}$ ( 0.75 inch) toward the side and front. This expansion and lateral movement will be restrained with expansion joints. Primenergy's cost estimate includes these expansion joints.

The penetration locations are provided in a schematic in the Appendix. Also a nomogram for penetration sizing based on the gas flow and number of penetration is provided for evaluation purposes.

\subsubsection{Overall Plant Energy Balance}

The following table 3-4 provides overall energy balance when the gasifier is integrated with the existing boiler. Since the turbine heat rate and electrical generation is based on the boiler output, the power output attributable to the gasifier is proportional to heat input from the gasifier to the boiler.

The annual electricity generated, poultry litter consumed and ash from the gasifier is calculated based on boiler and gasifier availability factor. It is assumed that the Reid boiler will be operated at capacity with $70 \%$ availability and that the gasifier will be available $90 \%$ of the time at $100 \%$ capacity when the Reid boiler is on line. Thus, overall gasifier contribution to the power generation is at $63 \%$ availability factor $(0.7 \times 0.9=0.63)$. 
Table 3-4 Energy Balance and Power Production for Reid Plant

\begin{tabular}{|c|c|c|}
\hline Item & & Units \\
\hline Poultry Litter & $7.45(8.20)$ & t/h (tons/hr) \\
\hline Heating Value (LHV) & $9,768 \quad(4,200)$ & $\mathrm{kJ} / \mathrm{kg}(\mathrm{Btu} / \mathrm{lb})$ \\
\hline Natural Gas & $20.9(46)$ & $\mathrm{kg} / \mathrm{h}(\mathrm{lbs} / \mathrm{hr})$ \\
\hline Heating Value (LHV) & $50,007(21,502)$ & $\mathrm{kJ} / \mathrm{kg}(\mathrm{Btu} / \mathrm{lb})$ \\
\hline Ash Produced & $1.96(2.16)$ & t/h (tons/hr) \\
\hline Total Boiler Heat Input @ 65.8 MW & $700,359 \quad(663.3)$ & MJ/h (MMBtu/hr) \\
\hline Heat Input to Boiler - Gasifier & $60,079(56.9)$ & MJ/h (MMBtu/hr) \\
\hline Boiler Efficiency (from BB Power) & $86.90(86.90)$ & $\%$ \\
\hline$\%$ Input from Gasifier & $8.6 \%(8.6 \%)$ & $\%$ \\
\hline T/G Output (design) & $65,851 \quad(65,851)$ & kWe \\
\hline Turbine Heat Rate (@ design pt.) & $9,358 \quad(8,863)$ & kJ/kWe (Btu/kWe) \\
\hline T/G Output Due to Gasifier & $5,648.9 \quad(5,648.9)$ & $\mathrm{kWe}$ \\
\hline Less Aux Load for Gasifier & $410.0(410.0)$ & $\mathrm{kWe}$ \\
\hline Total Gasifier Output Eq. kWe & $5,238.9 \quad(5,238.9)$ & $\mathrm{kWe}$ \\
\hline Boiler Availability Factor & $70 \%(70 \%)$ & $\% /$ year \\
\hline Gasifier Capacity Factor & $90 \%(90 \%$ & $\% /$ year \\
\hline Total Poultry Litter Usage & $41,091(45,254)$ & tpy (tons/yr) \\
\hline Total NG Usage & $115,255(253,865)$ & $\mathrm{kg} / \mathrm{y}(\mathrm{lbs} / \mathrm{y})$ \\
\hline Total Ash Produced & $10,814(1,910)$ & tpy (tons/yr) \\
\hline Total Power Produced & $28,912,496$ & $\mathrm{kWh} / \mathrm{y}$ \\
\hline
\end{tabular}

\subsubsection{Solids Handling Systems}

Concept for poultry litter receiving, storage and delivery was developed for the Reid plant site. Moisture content of the litter is a major material handling consideration because high moisture content can cause clogging of the fuel conveyance systems including bucket elevators, silos and air-conveyors. The moisture content of freshly collected litter is about 24 percent for the litter crust and about 32 percent for the total clean out. The corresponding wet bulk density is measured at about $492 \mathrm{~kg} / \mathrm{m}^{3}$ (830 lbs/cu. yd) for crust and $575.5 \mathrm{~kg} / \mathrm{m}^{3}(970$ Ibs./cu. yd) for clean out.

Three different concepts for material handling have been evaluated for the Reid plant site. 
- Conventional receiving and storage buildings with mechanical belt conveying to the day storage and to the gasifier

- Conventional receiving building with long term storage silos and pneumatic conveying into the gasifier

- Conventional receiving building with long term storage silos and mechanical belt conveying

Dynamic Air Inc. of St. Paul, MN conducted tests for pneumatic conveying of poultry litter in August 2001. The test results indicated that the poultry litter particles $12 \mathrm{~mm}\left(1 / 2^{\prime \prime}\right)$ and larger may bridge in a silo and cake sporadically in a dilute phase air conveying. The test results also indicate that poultry litter $6 \mathrm{~mm}$ $\left(1 / 4^{\prime \prime}\right)$ and smaller can be conveyed easily. However bed depth in the test silo was much less than $2.5 \mathrm{~m}(8 \mathrm{ft})$ that is the deepest bed depth recommended for storing poultry litter.

Litter is to be received in covered trucks at the Reid Plant site or other similar site. The truck will dump the load in an enclosed fuel unloading building.

Detailed cost estimate and auxiliary power consumption for each option was developed by contacting major equipment vendors. The major vendors contacted were Dynamic Air, Nol-Tec Industries, Saxlund International, Delta Ducon, Ward Equipment, Inc. The equipment cost supplied by the vendor was used to develop total installed cost of complete material handling system. The summary of the cost estimate is provided in table 4-1 in Section 4 Economic Analysis. The layout plans with the proposed mechanical and pneumatic conveying are provided in the Appendix A for the WKE case.

\subsubsection{Permit Issues}

Based on the past plant operating data for the Reid plant, the following is expected performance with poultry litter cofiring. Total Heat Input to the Boiler from Coal as reported for 1998 was $2.7 \times 10^{\wedge} 12 \mathrm{~kJ}\left(2.60 \times 10^{\wedge} 6 \mathrm{MMBtu}\right)$. Assuming similar level of heat input under cofiring, the following figures 3-2 provides breakdown of heat to the boiler from coal and poultry litter. 


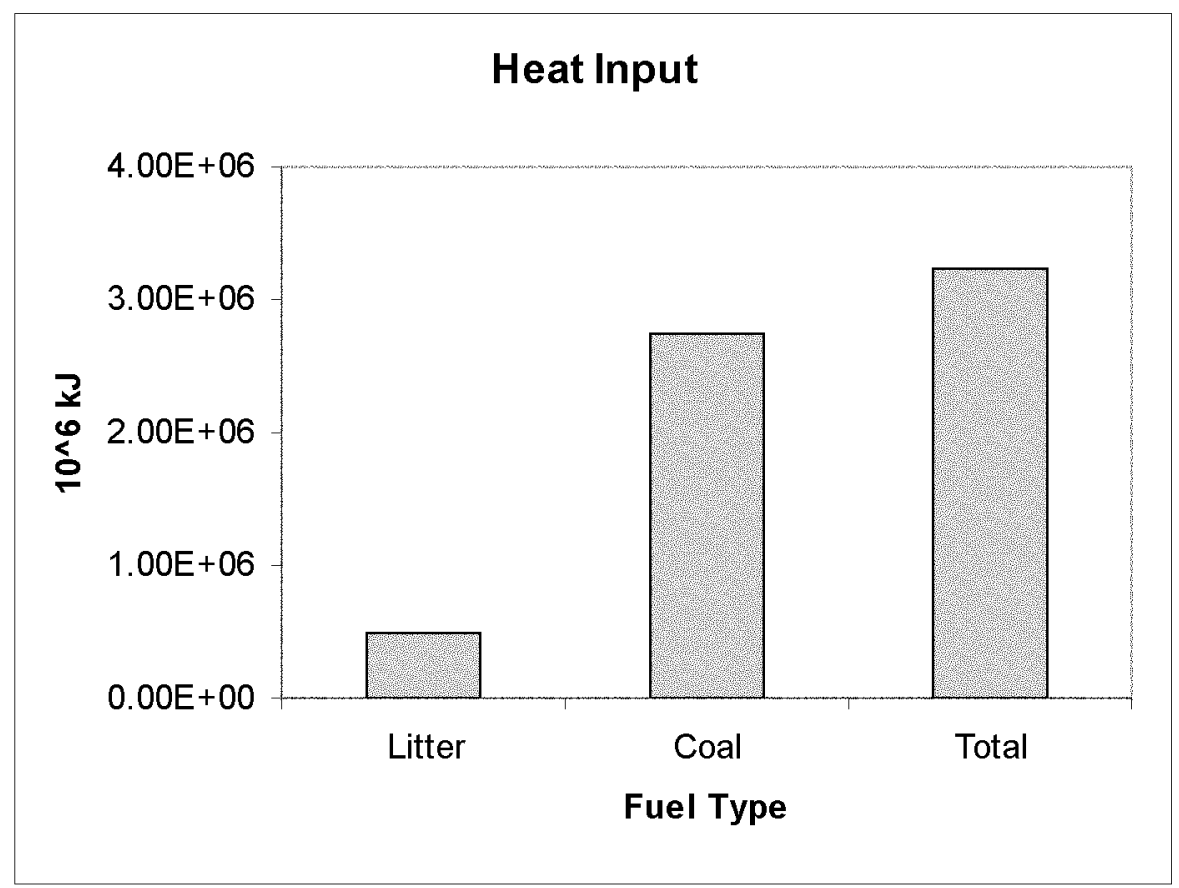

Figure 3-2 Heat input to the boiler with cofiring

NOx Emissions: Due to bound nitrogen in the poultry litter (urea/ ammonia), straight combustion of litter with excess air at high temperature would produce very high NOx. It could be as high as $>2000$ ppmv of NOx. But in gasifier with the low temperature of $815^{\circ} \mathrm{C}\left(\sim 1500^{\circ} \mathrm{F}\right)$ and reducing atmosphere the ammonia, amine and urea in the litter are released into the gas stream. With the over fire staged combustion (again in reducing atmosphere) these compounds will break down to $\mathrm{N} 2$ and $\mathrm{H} 2$ and $\mathrm{CO}$. From the past test run by Primenergy the NOx levels (preliminary) were in the range of $270 \sim 300 \mathrm{ppmv}$ or $0.174 \mathrm{~kg} / \mathrm{GJ}(0.404$ lbs/MMBtu) on HHV basis. This NOx level is lower than older PC fired boilers with regular burners and it is comparable to the boilers with new Low NOx burners using coal as a fuel. Thus the gasification based cofiring for the Reid boiler can be considered as $8 \sim 10 \%$ of the fuel input to the boiler going through an equivalent low NOx burner. Figure 3-3 show NOx contribution form gasifier to the existing boiler and expected overall NOx emission under cofiring conditions. 


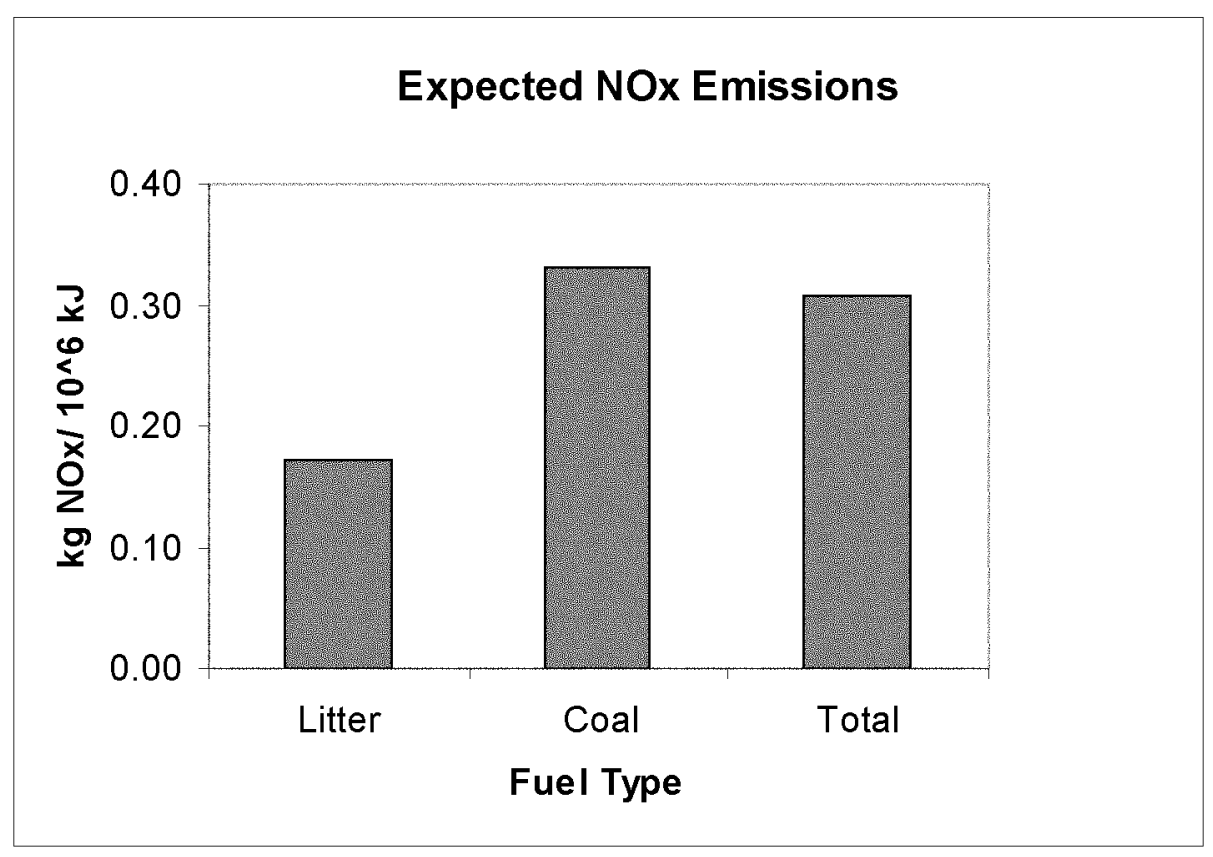

Figure 3-3 Expected NOx emissions with cofiring

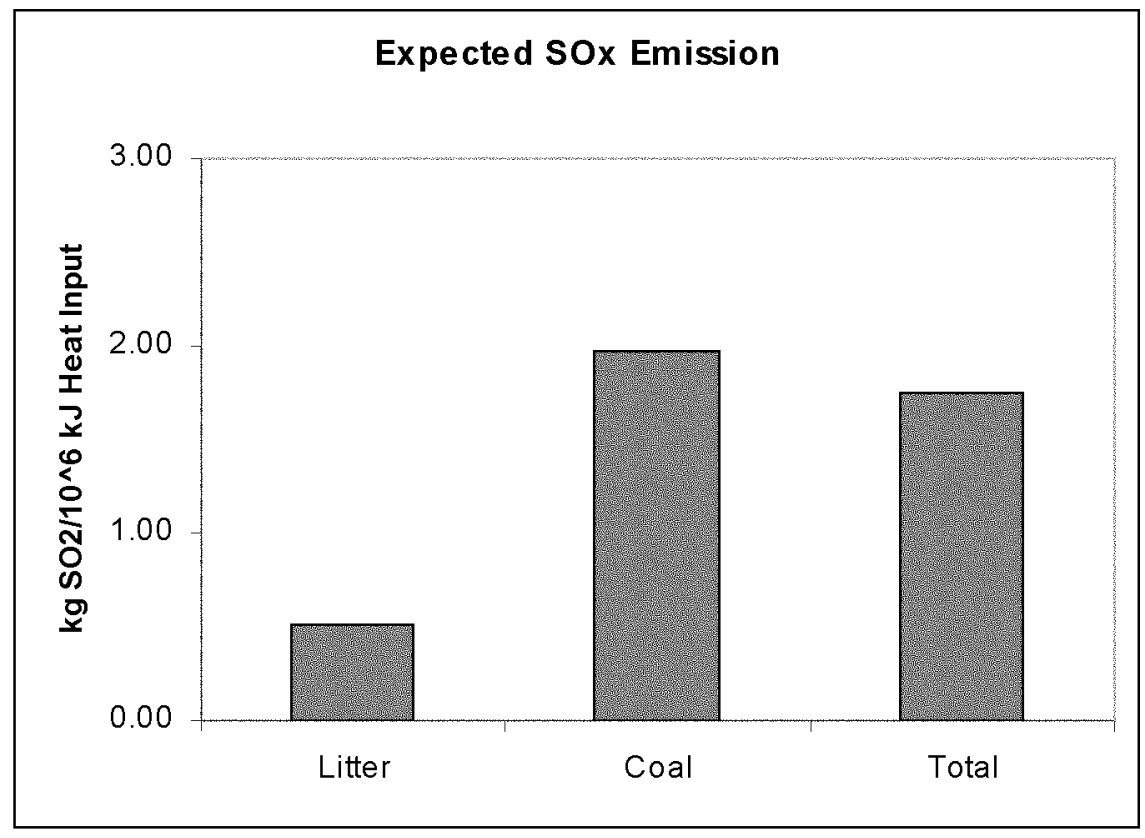

Figure 3-4 Expected $\mathrm{SO}_{2}$ emissions with cofiring

SO2 Emissions: Poultry litter has less than $0.5 \% \mathrm{~S}$. The Kentucky coal is about $2 \% \sim 2.5 \% \mathrm{~S}$. Thus, any heat input from low sulfur litter will reduce the $\mathrm{SO}_{2}$ 
emissions from the boiler. As figure 3-4 show, the sulfur in the litter is about $0.5 \mathrm{~kg} / \mathrm{GJ} \mathrm{v} / \mathrm{s} S$ in coal at $>2 \mathrm{~kg} / \mathrm{GJ}$. In addition, most of the sulfur in coal is in elemental form and forms $\mathrm{SO}_{2} / \mathrm{SO}_{3}$ in an oxidizing atmosphere. While, $\mathrm{S}$ in the litter is already in a bound form of sulfates and sulfides and hence it is expected to remain in the ash as sulfur compound, thus reducing amount of $\mathrm{SO}_{2}$ emission even further when cofiring.

Chlorine: Primenergy has not conducted specific tests on chlorine from the gasifier and no comparable literature data are available. But with the high alkali content of the litter most of the chlorine should remain as salt $(\mathrm{Na} / \mathrm{K} / \mathrm{Ca} / \mathrm{Mg})$ in the ash - again due to low temperature gasification in a reducing environment. The ash analyses of the litter sample indicate that $>90 \%$ of chlorine is retained in the ash. Further evaluation of chlorine in the gasifier gases by Primenergy has been planned.

Heavy Metals: Due to organic nature of the litter, there is very little, if any heavy metals. Elemental analyses of the litter and ash samples have not detected any mercury and insignificant amount of arsenic, etc. Hence, there is no burden of heavy metals from the gases entering the boiler from the gasifier.

Odor: By storing the litter in the enclosed building or the silos and using enclosed belt or pneumatic conveying and recycling this air as underfire combustion air, the project is expected to eliminate or minimize the odor from the litter.

Poultry litter is a renewable energy resource. The Reid plant will be able to reduce its fossil fuel consumption by $8 \sim 10 \%$ and can claim a reduction in greenhouse emissions $\left(\mathrm{CO}_{2}\right)$ from the boiler. Due to low sulfur content in the poultry litter, and two staged combustion process, the gasifier is expected to reduce the $\mathrm{SO}_{2}$ and $\mathrm{NOx}$ by over $5 \%$ from the boiler. With the hot gas filtration system, clean gas is fed into the existing boiler. This will reduce particulate loading on the electrostatic precipitator (ESP). Also, litter does not contain heavy metals, i.e. $\mathrm{Hg}, \mathrm{Cd}, \mathrm{Pb}$, etc., $8 \%$ reduction in coal burning will reduce heavy metals in the stack gases by proportionate amount.

A further discussion of emissions due to coal v/s litter is provided in the Results and Discussion section of this report.

\subsubsection{Fuel Contracts}

Contacts with two local haulers were established for the Reid plant case. Both haulers have shown interest and are willing to work with the project. For any similar project, the best strategy is to establish contracts with the haulers rather than individual farmers. Project recommends continue pursuing the local haulers for fuel supply. The haulers provided firm written estimates. Current estimate from both of these haulers for the liter supply is $\$ 10 /$ ton for up to 20000 tons of litter/year and at \$12/ton additional $30000-40000$ tons of litter delivered at the 
plant. The fuel cost was developed for economic analysis using an estimate of $\$ 12 /$ ton of litter delivered to the Reid plant. A sensitivity analysis was also generated with varying the cost of litter delivered at the site. The economic proforma and sensitivity analysis are included in the Results and Discussion section of this report.

\subsubsection{Major Equipment List}

A preliminary equipment list is prepared for the litter receiving, storage and transport to the gasifier island based on concepts described above. Primenergy prepared the gasifier island equipment list and cost estimate.

Material handling equipment list was developed using input from the vendors and from the site layout requirements. Table 3-5 provides major gasifier equipment and sizing. Table 3-6 provides litter receiving, storage and conveyance equipment and sizing. 
Table 3-5 Gasifier Island Equipment List

\begin{tabular}{|c|c|c|c|}
\hline Equipment & Quantity & Size/ Capacity & $\begin{array}{l}\text { Supplier/ } \\
\text { Vendor }\end{array}$ \\
\hline Fuel Feed Rotary Valve & 1 & $7.5 \mathrm{t} / \mathrm{h}-3.75 \mathrm{~kW}$ & Primenergy \\
\hline Fuel Infeed Auger & 1 & $3.75 \mathrm{~kW}$ & \\
\hline KC-18 Gasifier & 1 & $7.5 \mathrm{t} / \mathrm{h}$ & \\
\hline Agitator & 1 & $3.75 \mathrm{~kW}$ & \\
\hline Ash Discharge Auger \#1 & 1 & $2 . \mathrm{t} / \mathrm{h}-2.25 \mathrm{~kW}$ & \\
\hline Ash Discharge Auger \#2 & 1 & 2. $\mathrm{t} / \mathrm{h}-2.25 \mathrm{~kW}$ & \\
\hline Ash Cooling Auger & 1 & 2. $\mathrm{t} / \mathrm{h}-3.75 \mathrm{~kW}$ & \\
\hline Ash Silo & 1 & $4.5 \mathrm{~m} \mathrm{D} \times 7.5 \mathrm{~m} \mathrm{H}$ & \\
\hline Underfire Air Fan & 1 & $180 \mathrm{~m}^{3} / \mathrm{Min}-30 \mathrm{~kW}$ & \\
\hline Cooling Water Pump & 2 & $230 \mathrm{l} / \mathrm{min}-7.5 \mathrm{~kW}$ each & \\
\hline Hot Gas Filter & 1 & $750 \mathrm{C}, 300 \mathrm{~m}^{3} / \mathrm{Min}$ & \\
\hline Fly Ash Discharge Valve & 2 & $0.7 \mathrm{~kW}$ each & \\
\hline Final Ash Conveyor & 1 & $7.5 \mathrm{~kW}$ & \\
\hline ID Fan & 1 & $750 \mathrm{C}, 300 \mathrm{~m}^{3} / \mathrm{Min}, 185 \mathrm{~kW}$ & \\
\hline Overfire Combustion Chamber & 1 & Refractory Lined - & \\
\hline Overfire Air Fan & 1 & $20 \mathrm{C}, 35 \mathrm{~m}^{3} / \mathrm{Min}, 20 \mathrm{~kW}$ & \\
\hline Air Compressor & 1 & $200 \mathrm{~m}^{3} / \mathrm{Min}, 75 \mathrm{~kW}$ & \\
\hline Combustion Air Heater & 1 & $2.5 \mathrm{~m} \times 3.7 \mathrm{~m}$ & \\
\hline Refractory Lined Piping & As Req'd. & & \\
\hline Expansion Joints for boiler Penetrations & 4 & $510 \mathrm{~mm}$ diameter each & \\
\hline Pipe Supports & As Req'd & & \\
\hline MCC Unit & 1 & 30 CB Minimum & \\
\hline DCS Unit & 1 & 150 Analog, 50 Digital I/O & \\
\hline Operator Consoles & 2 & $\mathrm{~N} / \mathrm{A}$ & \\
\hline
\end{tabular}

Note: Primenergy will package the entire gasification island system and equipment. Hence, individual vendors for major equipment in the gasifier island are not listed. 
Table 3-6 Material Handling System Equipment List

\begin{tabular}{|c|c|c|c|}
\hline Equipment & Qty. & Size/ Capacity & Vendors \\
\hline Fuel Storage Silos & 2 & $9.1 \mathrm{~m} \times 21.5 \mathrm{~m}, 750 \mathrm{t}$ each & $\begin{array}{c}\text { Walker Equip., Industrial } \\
\text { Accessories, Chicago } \\
\text { Conveyor }\end{array}$ \\
\hline Vibrating Screen/ Grizzly & 1 & $3 \mathrm{~m} \times 2.5 \mathrm{~m}$ & $\begin{array}{l}\text { Martin Engineering, } \\
\text { Chicago, IL }\end{array}$ \\
\hline Fuel Unloading Pit & 1 & $3 \mathrm{~m} \times 2.5 \mathrm{~m} \times 3 \mathrm{~m}$ & $\begin{array}{c}\text { Saxlund International, } \\
\text { Delta Ducon, Ward Equip. }\end{array}$ \\
\hline Screw Conveyor & 1 & $10 \mathrm{~kW}$ & Delta Ducon, Ward Equip \\
\hline Bucket elevator & 1 & $0.5 \mathrm{~m} \times 40 \mathrm{~m} \mathrm{H}, 5 \mathrm{~kW}$ & $\begin{array}{c}\text { Delta Ducon, Newton } \\
\text { Conveyors } \\
\end{array}$ \\
\hline Fuel Diverter Valve & 1 & $0.5 \mathrm{~kW}$ & Delta Ducon, Ward Equip \\
\hline Fuel Storage Building & 1 & $12 \mathrm{~m} \times 8 \mathrm{~m} \times 11 \mathrm{~m}$ & $\begin{array}{l}\text { Local Construction } \\
\text { Contractor }\end{array}$ \\
\hline Fuel Storage Bldg. Ventilation System & 1 & $10 \mathrm{~kW}$ & ScrubAir, BSM Ventilation \\
\hline Fan Blower for Fuel Conveyor & 1 & $5 \mathrm{~kW}$ & $\begin{array}{c}\text { Saxlund International, } \\
\text { Delta Ducon, Ward Equip. }\end{array}$ \\
\hline Rotary Valve & 2 & $5 \mathrm{~kW}$ & Ward Equip. \\
\hline Fuel Day Silo & 1 & $5 \mathrm{~m} \times 10 \mathrm{~m}$ & Primenergy \\
\hline Cyclone Separator & 1 & $95 \%$ Eff., $1.2 \mathrm{~m} \times 2.4 \mathrm{~m}$ & Ducon Technologies \\
\hline Separation Screen & 1 & $15 \mathrm{~mm}$ Mesh & Delta Ducon, Ward Equip \\
\hline Hammer Mill & 1 & $37.5 \mathrm{~kW}$ & $\begin{array}{c}\text { Stedman Machine, CPM } \\
\text { Crop, CS Bell Co. }\end{array}$ \\
\hline Hammer Mill Air System & 1 & 12 kW Air Fan & $\begin{array}{c}\text { Stedman Machine, CPM } \\
\text { Crop, CS Bell Co. }\end{array}$ \\
\hline Silo Unloader & 1 & $11.5 \mathrm{~kW}$ & Delta Ducon, Ward Equip \\
\hline Silo Discharge Conveyor & 1 & $7.5 \mathrm{~kW}$ & $\begin{array}{c}\text { Nordberg, Inc., Newton } \\
\text { Conveyors }\end{array}$ \\
\hline Metering Bin Discharge Screw & 1 & $5 \mathrm{~kW}$ & Primenergy. \\
\hline Bucket Elevator & 1 & $3.75 \mathrm{~kW}, 0.8 \mathrm{~m} \times 1 \mathrm{~m} \times 15 \mathrm{~m}$ & $\begin{array}{c}\text { Saxlund International, } \\
\text { Delta Ducon, Ward Equip. }\end{array}$ \\
\hline
\end{tabular}

\subsubsection{Equipment Layout}

The proposed equipment layout for the fuel handling system and the gasifier island are provided in the Appendix A the WKE case. 


\subsection{TXU Energy Case}

\subsubsection{TXU Monticello Plant}

TXU Monticello plant is a three unit coal fired plant. For the Biomass cofiring project, Unit 1 was selected as a case study. The following picture in figure 3-5 shows Unit 1 side elevation.

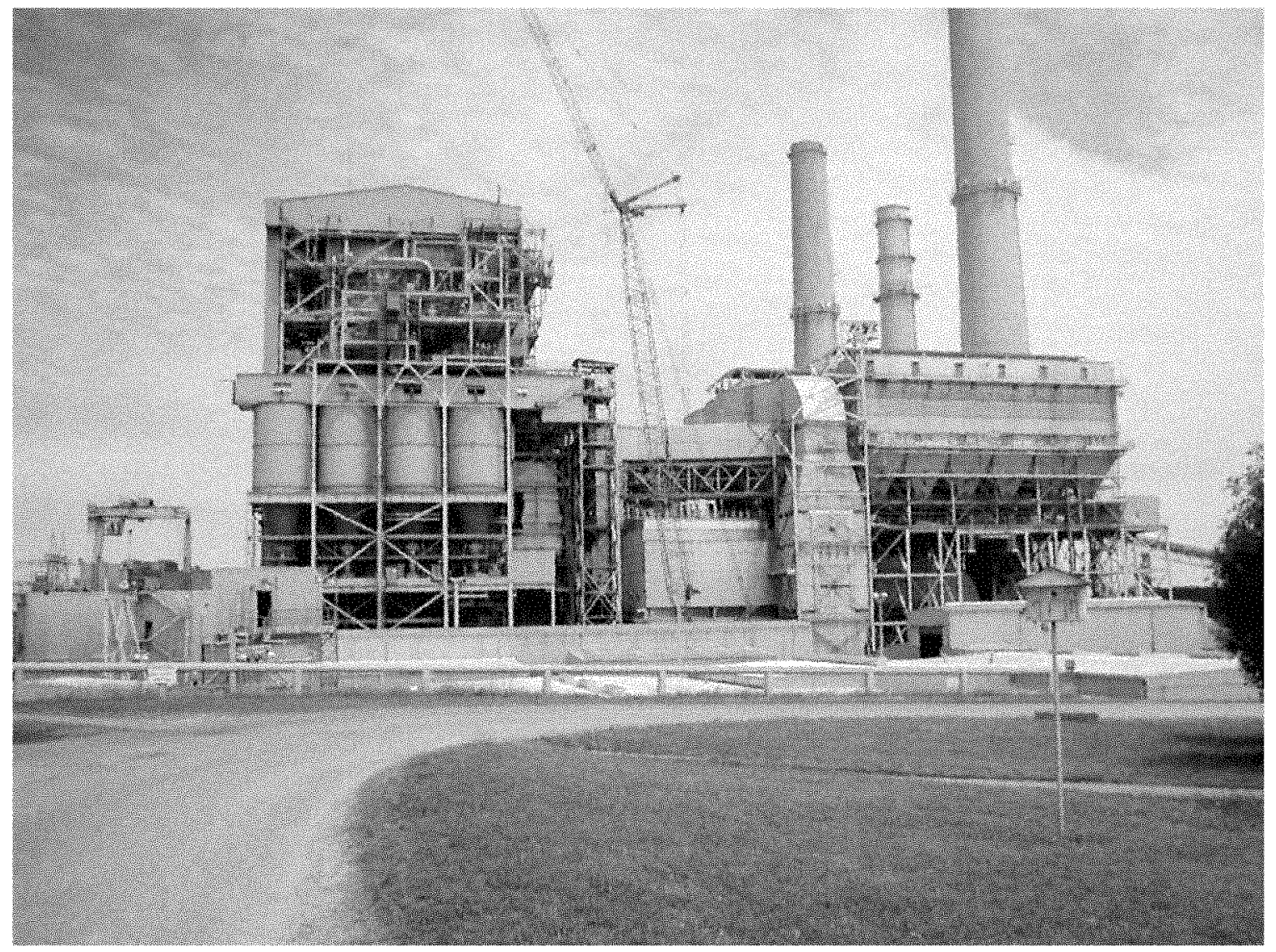

Figure 3-5 Monticello Plant Unit 1

Monticello Unit 1 is a Combustion Engineering (Alstom) tangentially fired pulverized coal unit burning a blend of Texas lignite and Wyoming subbituminous Powder River Basin (PRB) coal. The design specifications for the unit 1 boiler are provided in Table 3-7. 


\subsubsection{Monticello Unit 1 Boiler Data}

Table 3-7 Design Specifications for Monticello Unit 1

\begin{tabular}{|c|c|c|c|}
\hline Boiler Parameters & Units & Control Point & MCR \\
\hline Fuel & & Texas Lignite & Texas Lignite \\
\hline Evaporation & $\begin{array}{l}\mathrm{kg} / \mathrm{h} \\
(\mathrm{Lbs} / \mathrm{h})\end{array}$ & $\begin{array}{c}1451496 \\
(3200000)\end{array}$ & $\begin{array}{c}1825709 \\
(4025000)\end{array}$ \\
\hline FW Temp & ${ }^{\circ} \mathrm{C}\left({ }^{\circ} \mathrm{F}\right)$ & $248(478)$ & $261(501)$ \\
\hline FW Pressure (calc) & $\mathrm{kPa}$ (psig) & $25943(3750)$ & $28135(4068)$ \\
\hline SH Outlet Temp & ${ }^{\circ} \mathrm{C}\left({ }^{\circ} \mathrm{F}\right)$ & $541(1005)$ & $541(1005)$ \\
\hline SH Outlet Press & $\mathrm{kPa}$ (psig) & 24877 (3 595) & $26462(3825)$ \\
\hline SH Pressure Drop & $\mathrm{kPa}$ (psig) & $1075(141)$ & $1633(222)$ \\
\hline Reheat Flow & $\begin{array}{c}\mathrm{kg} / \mathrm{h} \\
(\mathrm{lbs} / \mathrm{h})\end{array}$ & $\begin{array}{c}1276409 \\
(2814000)\end{array}$ & $\begin{array}{c}1596645 \\
(3520000) \\
\end{array}$ \\
\hline Reheat inlet Temp & ${ }^{\circ} \mathrm{C}\left({ }^{\circ} \mathrm{F}\right)$ & $288(550)$ & $300(572)$ \\
\hline Reheat Inlet Press & $\mathrm{kPa}$ (psig) & $3838(542)$ & $4798(682)$ \\
\hline Reheat Outlet Temp & ${ }^{\circ} \mathrm{C}\left({ }^{\circ} \mathrm{F}\right)$ & $541(1005)$ & $541(1005)$ \\
\hline Reheater Press Drop & $\mathrm{kPa}(\mathrm{psig})$ & $193(28)$ & $241(35)$ \\
\hline Economizer Press Drop & $\mathrm{kPa}(\mathrm{psi})$ & $96.5(14)$ & $148(21)$ \\
\hline Gas Drop - Furnace to Econ & $\mathrm{Pa}($ ("wg) & $616(2.45)$ & $918(3.65)$ \\
\hline Gas Drop Econ Outlet to AH Outlet & Pa ("wg) & $1208(4.80)$ & $1724(6.85)$ \\
\hline Gas Temp Entering $\mathrm{AH}$ & ${ }^{\circ} \mathrm{C}\left({ }^{\circ} \mathrm{F}\right)$ & $429(805)$ & $460(860)$ \\
\hline Gas Temp Leaving $\mathrm{AH}$ & ${ }^{\circ} \mathrm{C}\left({ }^{\circ} \mathrm{F}\right)$ & $164(327)$ & $177(351)$ \\
\hline Gas Temp Leaving $\mathrm{AH}$ & ${ }^{\circ} \mathrm{C}\left({ }^{\circ} \mathrm{F}\right)$ & $155(311)$ & $169(336)$ \\
\hline Air Temp Air Heater & ${ }^{\circ} \mathrm{C}\left({ }^{\circ} \mathrm{F}\right)$ & $29(85)$ & $29(85)$ \\
\hline Air Temp Leaving & ${ }^{\circ} \mathrm{C}\left({ }^{\circ} \mathrm{F}\right)$ & $372(701)$ & $388(730)$ \\
\hline Air Press Air Heater & $\mathrm{Pa}(" w g)$ & $1988(7.90)$ & $2605(10.35)$ \\
\hline Amb. Air Temp & ${ }^{\circ} \mathrm{C}\left({ }^{\circ} \mathrm{F}\right)$ & $26.5(80)$ & $26.5(80)$ \\
\hline Excess Air Econ & $\%$ & 20 & 20 \\
\hline Fuel Fired & $\begin{array}{c}\mathrm{kg} / \mathrm{h} \\
(\mathrm{Lbs} / \mathrm{h}\end{array}$ & $\begin{array}{c}308896 \\
(681000) \\
\end{array}$ & $\begin{array}{c}379203 \\
(836000) \\
\end{array}$ \\
\hline Efficiency & $\%$ & 82.69 & 82.06 \\
\hline
\end{tabular}

Although the design specifications for the Monticello plant call for Texas lignite as primary fuel, the current fuel for the plant is blend of Texas lignite and Wyoming coal from the Powder River basin (PRB sub-bituminous coal). The normal blend is $60 \%$ Texas lignite and $40 \%$ PRB coal. Table 3-8 provides the current fuel analysis for the Monticello plant. 
Table 3-8 Monticello Boiler Fuel Analyses

\begin{tabular}{|c|c|c|c|}
\hline & Texas Lignite & PRB Coal & Units \\
\hline Fuel HHV & $\begin{array}{l}15719 \\
(6767)\end{array}$ & $\begin{array}{l}18084 \\
(8220)\end{array}$ & $\begin{array}{c}\mathrm{kJ} / \mathrm{kg} \\
(\mathrm{Btu} / \mathrm{lb})\end{array}$ \\
\hline $\mathrm{C}$ & 39.20 & 46.52 & $\%$ \\
\hline $\mathrm{H}$ & 2.99 & 3.16 & 1 \\
\hline 0 & 11.04 & 15.04 & \\
\hline $\mathrm{N}$ & 0.58 & 0.70 & \\
\hline$S$ & 0.61 & 0.48 & \\
\hline Ash & 14.31 & 6.44 & \\
\hline Moisture & 31.27 & 27.66 & \\
\hline Total & 100.00 & 100.00 & \\
\hline
\end{tabular}

\subsubsection{Gasifier Material and Energy Balance}

After reviewing the available poultry litter supply in the vicinity of the Monticello plant, the gasifier for the Monticello unit 1 plant is sized for $14.4 \mathrm{t} / \mathrm{h}$ (15.8-ton/hr) capacity. This is two $\mathrm{KC}-18$ gasifier systems with common fuel conveying and storage system as well as common ash silo and single duct of fuel gas to the unit 1 boiler. Material and energy balance for the $\mathrm{KC}-18$ has been prepared and a summary of it is included in Table 3-9 with detailed balance in the Appendix of this report. The gasifiers and fuel storage system will be located on south side of Unit 1 near the current Document Control Center (DCC). The fuel gases from the gasifiers will be filtered and cooled to $350^{\circ} \mathrm{C}\left(650^{\circ} \mathrm{F}\right)$ and transported to the boiler in refractory lined piping.

Possible alternate site for the gasifier is east of the rail rod tracks in the vicinity of the long-term coal storage area.

The following two tables 3-9 and 3-10 provides material and energy balance for specific streams. Refer to the stream number in the process flow diagram provided in the Appendix B TXU case. 
Table 3-9 Material Balance for the gasifier

\begin{tabular}{|c|c|c|c|c|c|c|c|}
\hline Selected Stream & 1 & 2 & 3 & 5 & 7 & 8 & 11 \\
\hline Name & $\begin{array}{c}\text { Gasifier } \\
\text { Feed }\end{array}$ & $\begin{array}{c}\text { GASIFIER } \\
\text { AIR }\end{array}$ & $\begin{array}{c}\text { GASIFIER } \\
\text { BOTTOM } \\
\text { ASH }\end{array}$ & $\begin{array}{c}\text { SYNGAS } \\
\text { SCRUBBER } \\
\text { EXHAUST }\end{array}$ & $\begin{array}{c}\text { ID } \\
\text { FAN } \\
\text { EXHAUST }\end{array}$ & $\begin{array}{c}\text { OVERFIRE } \\
\& \text { REOX } \\
\text { AIR }\end{array}$ & $\begin{array}{c}\text { COMB } \\
\text { PROD TO } \\
\text { BOILER }\end{array}$ \\
\hline Pressure kPa ("w.c.-g) & --- & $6.29(25.0)$ & --- & $-2.52(-10.0)$ & $2.01(8.0)$ & 3.78. (15.0) & $1.510(6.0)$ \\
\hline Temperature ${ }^{\circ} \mathrm{C}\left({ }^{\circ} \mathrm{F}\right)$ & $25(77)$ & $25(77)$ & $149(300)$ & $760(1400)$ & $350(662)$ & $25(77)$ & $1304(2379)$ \\
\hline $\begin{array}{l}\text { Molecular Weight kg/kgmole } \\
\text { (or lbs/lb mole) }\end{array}$ & --- & 28.68 & 75.25 & 24.39 & 24.39 & 28.68 & 28.33 \\
\hline Component & $\mathrm{kg} / \mathrm{h}(\mathrm{lb} / \mathrm{hr})$ & $\mathrm{kg} / \mathrm{h}(\mathrm{lb} / \mathrm{hr})$ & $\mathrm{kg} / \mathrm{h}(\mathrm{lb} / \mathrm{hr})$ & $\mathrm{kg} / \mathrm{h}(\mathrm{lb} / \mathrm{hr})$ & $\mathrm{kg} / \mathrm{h}(\mathrm{lb} / \mathrm{hr})$ & $\mathrm{kg} / \mathrm{h}(\mathrm{lb} / \mathrm{hr})$ & $\mathrm{kg} / \mathrm{h}(\mathrm{lb} / \mathrm{hr})$ \\
\hline Carbon & $\begin{array}{c}4604 \\
(10151)\end{array}$ & & $420(927)$ & & & & \\
\hline Hydrogen & $462(1019)$ & & & & & & \\
\hline Nitrogen & $472(1041)$ & & & & & & \\
\hline Oxygen & 3236 (7 135) & & & & & & \\
\hline Sulfur & $100(221)$ & & $50(111)$ & & & & \\
\hline \multicolumn{8}{|l|}{ Chlorine } \\
\hline \multicolumn{8}{|l|}{ Fuel Gas } \\
\hline Carbon Monoxide & & & & $\begin{array}{c}4669 \\
(10293) \\
\end{array}$ & $\begin{array}{c}4669 \\
(10293) \\
\end{array}$ & & \\
\hline Carbon Dioxide & & & & $\begin{array}{c}7996 \\
(17628)\end{array}$ & $\begin{array}{c}7996 \\
(17628)\end{array}$ & & $\begin{array}{c}15331 \\
(33799) \\
\end{array}$ \\
\hline Hydrogen & & & & $440(971)$ & $440(971)$ & & \\
\hline Water (v) & & $231(510)$ & & $\begin{array}{c}4897 \\
(10795)\end{array}$ & $\begin{array}{c}4897 \\
(10795) \\
\end{array}$ & $197(435)$ & $\begin{array}{c}9247 \\
(20386)\end{array}$ \\
\hline Nitrogen & & $\begin{array}{c}18059 \\
(39813) \\
\end{array}$ & & $\begin{array}{c}18531 \\
(40854) \\
\end{array}$ & $\begin{array}{r}18531 \\
(40854) \\
\end{array}$ & $\begin{array}{c}15414 \\
(33982) \\
\end{array}$ & $\begin{array}{c}50950 \\
(112326) \\
\end{array}$ \\
\hline Oxygen & & $\begin{array}{c}5467 \\
(12053)\end{array}$ & & & & $\begin{array}{l}4666 \\
10287 \\
\end{array}$ & $\begin{array}{c}3653 \\
(8053) \\
\end{array}$ \\
\hline Sulfur Dioxide & & & & $100(221)$ & $100(221)$ & & \\
\hline \multicolumn{8}{|l|}{ Hydrogen Chloride } \\
\hline Ash & 1912 (4 216) & & $1864(4110)$ & & & & \\
\hline \multicolumn{8}{|l|}{ Lime } \\
\hline Water $(I)$ & 3596 (7 927) & & & & & & \\
\hline TOTAL & $\begin{array}{c}14383 \\
(31710) \\
\end{array}$ & $\begin{array}{l}23757 \\
(52376) \\
\end{array}$ & $\begin{array}{l}2335 \\
(5147) \\
\end{array}$ & $\begin{array}{l}36633 \\
(80761) \\
\end{array}$ & $\begin{array}{l}36633 \\
(80761) \\
\end{array}$ & $\begin{array}{l}20277 \\
(44704) \\
\end{array}$ & $\begin{array}{c}79181 \\
(174564) \\
\end{array}$ \\
\hline
\end{tabular}


Table 3-10 Energy balance for the gasifier

\begin{tabular}{|c|c|c|c|c|c|c|c|}
\hline Selected Stream & 1 & 2 & 3 & 5 & 7 & 8 & 11 \\
\hline \multirow{3}{*}{ Name } & Gasifier & GASIFIER & GASIFIER & SYNGAS & ID & OVERFIRE & COMB \\
\hline & Feed & AIR & BOTTOM & SCRUBBER & FAN & \& REOX & PROD TO \\
\hline & & & $\mathrm{ASH}$ & EXHAUST & EXHAUST & AIR & BOILER \\
\hline TOTAL & $\begin{array}{c}14383 \\
(31710) \\
\end{array}$ & $\begin{array}{c}23757 \\
(52376) \\
\end{array}$ & $\begin{array}{r}2335 \\
(5147) \\
\end{array}$ & $\begin{array}{c}36633 \\
(80761) \\
\end{array}$ & $\begin{array}{l}36633 \\
(80761) \\
\end{array}$ & $\begin{array}{l}20277 \\
(44704) \\
\end{array}$ & \begin{tabular}{|c|}
79181 \\
$(174564)$ \\
\end{tabular} \\
\hline $\begin{array}{l}\text { AVAIL ENERGY VALUE } \\
(\text { LHV-HV) kJ/kg (Btu/lb) }\end{array}$ & $\begin{array}{l}10561 \\
(4537)\end{array}$ & & & $\begin{array}{l}2749 . \\
(1181)\end{array}$ & $\begin{array}{l}2749 . \\
(1181)\end{array}$ & & \\
\hline $\begin{array}{l}\text { AVAILABLE ENERGY GJ/h } \\
\text { (MMBtu/hr) }\end{array}$ & $\begin{array}{c}151.9 \\
(143.85) \\
\end{array}$ & & $\begin{array}{c}13.8 \\
(13.06) \\
\end{array}$ & $\begin{array}{l}100.7 \\
95.35 \\
\end{array}$ & $\begin{array}{l}1007 \\
95.35 \\
\end{array}$ & & \\
\hline $\begin{array}{l}\text { SENSIBLE ENERGY GJ/h } \\
\text { (MMBtu/hr) }\end{array}$ & & & & $\begin{array}{c}37.4 \\
(35.43)\end{array}$ & $\begin{array}{c}15.7 \\
(14.90)\end{array}$ & & $\begin{array}{c}129.7 \\
122.86\end{array}$ \\
\hline FLOW RATE M3/s (scfm) & & $\begin{array}{c}5.45 \\
(11551)\end{array}$ & & $\begin{array}{c}9.88 \\
(20940)\end{array}$ & $\begin{array}{c}9.88 \\
(20940)\end{array}$ & $\begin{array}{l}4.65 \\
9859\end{array}$ & $\begin{array}{c}18.39 \\
(38968)\end{array}$ \\
\hline
\end{tabular}

\subsubsection{Gasifier Boiler Integration}

Alstom Inc. (current holder of Combustion Engineering boiler technology) was contacted by the project for engineering recommendations. Since the total energy input from the gasifier to the boiler was about $2 \%$ of boiler MCR ratings, Alstom did not require engineering evaluation of the boiler heat transfer characteristics. Location of boiler penetration was discussed with Alstom. Alstom recommended that with tangentially fired boiler, the gas burners can be located on any of the four walls of the boiler at any of the existing burner level or just above it.

\subsubsection{Overall Plant Energy Balance}

The following table provides overall energy balance when the gasifier is integrated with the existing unit 1 boiler. Since the turbine heat rate and electrical generation is based on the boiler output, the power output attributable to the gasifier is proportional to heat input from the gasifier to the boiler.

The annual electricity generated, poultry litter consumed and ash from the gasifier is calculated based on boiler and gasifier availability factor. The Monticello plant is a base loaded unit with annual capacity factor of over $80 \%$. For the power generation and cost analysis purpose, it is assumed that the Monticello unit 1 boiler will be operated at capacity with $80 \%$ availability and that the gasifier will be available $90 \%$ of the time at $100 \%$ capacity when the unit 1 boiler is on line. Thus, overall gasifier contribution to the power generation is at $72 \%$ availability factor $(0.8 \times 0.9=0.72)$. Table $3-11$ show power generation contribution due to gasifier. 
Table 3-11 Energy Balance and Power Production for Monticello Case

\begin{tabular}{|c|c|c|c|}
\hline Item & & & Units \\
\hline Poultry Litter & 14.53 & $(16.00)$ & t/h (tons/hr) \\
\hline Heating Value (LHV) & 9,768 & $(4,200)$ & $\mathrm{kJ} / \mathrm{kg}(\mathrm{Btu} / \mathrm{lb})$ \\
\hline Natural Gas & - & - & $\mathrm{kg} / \mathrm{h}(\mathrm{lbs} / \mathrm{hr})$ \\
\hline Heating Value (LHV) & 50,007 & $(21,502)$ & $\mathrm{kJ} / \mathrm{kg}(\mathrm{Btu} / \mathrm{lb})$ \\
\hline Nominal Ash in Litter & $18 \sim 23$ & $(18 \sim 23)$ & $\%$ \\
\hline Ash Produced (@23\% Level) & 3.34 & $(3.68)$ & t/h (tons/hr) \\
\hline Total Boiler Heat Input @ 65.8 MW & $4,865,794$ & $(4,608)$ & MJ/h (MMBtu/hr) \\
\hline Heat Input to Boiler - Gasifier & 127,127 & $(120.4)$ & MJ/h (MMBtu/hr) \\
\hline Boiler Efficiency (CE-Nameplate) & 82.61 & $(82.61)$ & $\%$ \\
\hline$\%$ Input from Gasifier & $2.6 \%$ & $(2.6 \%)$ & $\%$ \\
\hline T/G Output (design) & 543,189 & $(543,189)$ & kWe \\
\hline Turbine Heat Rate (@ design pt.) & 9,429 & $(8,930)$ & kJ/kWh (Btu/kWh) \\
\hline \multicolumn{4}{|l|}{ (Estimate from Design data) } \\
\hline T/G Output Due to Gasifier & $13,482.7$ & $(13,482.7)$ & $\mathrm{kWe}$ \\
\hline Less Aux Load for Gasifier & 700.0 & $(700.0)$ & kWe \\
\hline Total Gasifier Output Eq. kWe & $12,782.7$ & $(12,782.7)$ & kWe \\
\hline Boiler Availability Factor & $80 \%$ & $(80 \%)$ & $\% /$ year \\
\hline Gasifier Capacity Factor & $90 \%$ & $(90 \%)$ & $\% /$ year \\
\hline Total Poultry Litter Usage & 91,631 & $(100,915)$ & tpy (tons/yr) \\
\hline Total NG Usage & - & - & $\mathrm{kg} / \mathrm{y}(\mathrm{lbs} / \mathrm{y})$ \\
\hline Total Ash Produced & 21,075 & $(23,210)$ & tpy (tons/yr) \\
\hline Total Power Produced & $80,622,887$ & $(80,622,887)$ & $\mathrm{kWh} / \mathrm{y}$ \\
\hline
\end{tabular}

\subsubsection{Solids Handling Systems}

The concept of delivery, receiving, and storage of 'poultry litter', which is referred to as 'fuel' from this point on, has been developed for the Monticello plant site. The moisture content of the fuel is a major consideration because high moisture content can cause clogging of the fuel conveyance systems including hoppers, bucket elevators, silos, and pneumatic conveyors. The moisture content of the freshly collected fuel is about 24 percent for the crust, and about 32 percent for the total clean-out. The corresponding wet bulk density is about $492 \mathrm{~kg} / \mathrm{m}^{3}(830$ $\mathrm{lb} / \mathrm{cu}$. yd) for crust, and $575.5 \mathrm{~kg} / \mathrm{m}^{3}$ (970 lb/cu. yd) for total clean-out.

Two different approaches for fuel handling have been evaluated for the Monticello plant site: 
- Fully automated system with minimal human operation

- Partially automated system with some human operation

In the fully automated approach, no part of the system would require any human intervention during normal operation. The entire fuel handling system, starting from the fuel receiving process down to the fuel feeding into the metering bins, is operated automatically. This eliminates the operational expenses due to the additional personnel needed to operate the non-automatic parts of the fuel handling system.

In the partially automated approach, one part of the fuel transfer operation from the long-term storage is carried out by the plant operating personnel. The truck delivery is for 10 hours a day from Monday through Friday. For the rest of the period during a week, the fuel is fed from the long-term storage to the feed hopper by plant operating personnel. This reduces the initial cost of providing for the automated facility, but increases the operational expenses due to the additional personnel needed to operate the non-automatic parts of the fuel handling system.

Detailed cost estimates for each approach have been developed by contacting major equipment suppliers and manufacturers. The major suppliers/ manufacturers contacted include Nol-Tec Industries, Newton Conveyors, Inc., Cleburne, TX, Goodman Conveyor Co. Belton, SC, Pennsylvania Crusher Corp, PA, ROXON Oy, Hollola, Finland, Jeffrey Specialty Equipment, Woodruff, SC, PEBCO (Cleveland Armstrong), Paducah, KY, Conveyor Eng \& Mfg. Co., Cedar Rapid, lowa, West Salem M/C Co., Salem, OR, Martin Engineering, Chicago, IL, Prok International, Vancouver, BC, Canada, Compass Equipment, Oroville, CA, and Western States Industrial Technologies, Inc. Tahoe Vista, CA. The equipment cost supplied by the vendors was used to develop total installed cost of the complete fuel handling systems. The summary of the cost estimate is presented in the table 4-7 in the Economic Analysis section. The system process flow diagrams, and plant facilities and equipment arrangement drawings are presented in the Appendix B.

All the fuel storage, transfer, and feed areas are fully enclosed with covers to contain the odor.

The fuel is supplied to the gasifier plant at a normal continuous rate of $14.5 \mathrm{t} / \mathrm{h}$ (16 tons per hour).

\section{a. Fully Automated System}

The fully automated fuel handling process consists of the following steps: 
- Delivery and Receiving. A number of bottom-dump trucks collect fuel from off-site sources and deliver to the site inside a fuel receiving building

- Transfer to Long-Term Storage. Fuel is then transferred to a long-term storage silo

- Shredding and Size Reduction. Fuel is then withdrawn and fed into a shredder where it is reduced to size $6 \mathrm{~mm}(1 / 4 \mathrm{in}$.) and smaller

- Transfer to Short-Term Storage. Shredded fuel is then transferred to a day-storage silo for short-term storage

- Metering and Feeding to Gasifier. Fuel from the day silo is then transferred to two metering bins where it is weighed and fed into the gasifier.

Delivery and Receiving: The fuel from off-site locations is shipped into the Fuel Receiving Building into which the access to the trucks is provided by a lightweight and quick-opening automatic door. The bottom-dump trucks then drop the fuel on to a horizontal screw conveyor through a vibrating hopper and a variable opening gate. The variable opening gate facilitates fuel transfer at a controlled rate. The fuel delivery and receiving process operates 10 hours a day for 5 days a week. In order to supply fuel at the normal continuous rate of $14.5 \mathrm{t} / \mathrm{h}$ (16 short tons per hour) to the gasification plant, the delivery and receiving process is designed for a nominal capacity of 50t/h (55 short tons per hour) and a peak capacity of $55(60)$ tons per hour. This provides for a margin of approximately 10 percent.

The fuel Receiving Building is $18 \mathrm{~m} \times 6 \mathrm{~m}$ ( $60 \mathrm{ft}$ by $20 \mathrm{ft}$.) The receiving hopper, gate, and the screw conveyor are located below the grade level.

Transfer to Long-Term Storage: The fuel is then transferred to the long-term Storage Silo. The screw conveyor transports the fuel on to a bucket elevator, which elevates the fuel to the top of the Storage Silo. The long-term Storage Silo has a capacity of 5 days storage, is made of concrete, and is $24.4 \mathrm{~m}(80 \mathrm{ft}$.) in diameter and $7.6 \mathrm{~m}$ ( $25 \mathrm{ft}$.) tall. The long-term storage ensures continuous fuel supply in case of any long-term interruption in fuel deliver and receiving. To store fuel uniformly within the large-diameter silo, a horizontal distribution conveyor belt is used, which rotates over the top of the silo. As the delivery and receiving process, the process of transferring to long-term storage is also designed for a nominal capacity of $50(54)$ tons per hour and a peak capacity of $55(60)$ tons per hour.

Shredding and Size Reduction: For efficient gasification, the fuel is required to be sized to $6 \mathrm{~mm}(1 / 4 \mathrm{in}$.) and smaller. The fuel from the Storage Silo is fed to a shredder through a vibrating hopper and a variable opening gate. The shredding 
process is designed for a nominal capacity of $14.5 \mathrm{t} / \mathrm{h}$ (16 short tons per hour) and a peak capacity of $18 \mathrm{t} / \mathrm{h}$ ( 20 tons per hour). This provides for a 25 percent margin.

Transfer to Short-Term Storage: Shredded fuel is then transferred to the Day Silo for short-term storage. The short-term storage Day Silo has a capacity of

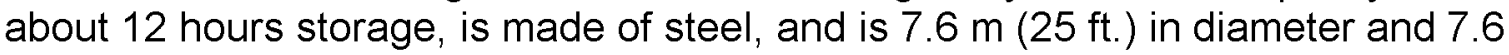
$\mathrm{m}(25 \mathrm{ft}$.) tall. Due to the small granular nature of the fuel, a pneumatic conveying system is used to transfer the fuel. The conveying system is designed for a nominal capacity of 16 short tons per hour and a peak capacity of 20 tons per hour. The short-term storage ensures continuous fuel supply in case of any short-term interruption in the shredding and size reduction process.

Metering and Feeding to Gasifier: The fuel from the Day Silo is fed to two vibrating hoppers each with a variable opening gate. The gates allow the fuel to drop to two conveyor belts. The two conveyor belts transfer the fuel to two metering bins for weighing and finally feeding the gasifier. The process is designed for a nominal capacity of 16 short tons per hour and a peak capacity of 20 tons per hour.

\section{b. Partially Automated System}

The partially automated fuel handling process consists of the following steps:

- Delivery and Receiving. A number of side-dump trucks collect fuel from off-site sources and deliver to the site inside the long-term Fuel Storage Building.

- Shredding and Size Reduction. Fuel is then withdrawn and fed into a

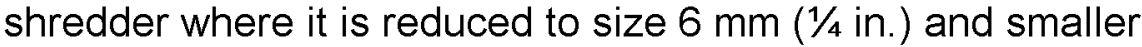

- Transfer to Short-Term Storage. Shredded fuel is then transferred to a day-storage silo for short-term storage

- Metering and Feeding to gasifier. Fuel from the day silo is then transferred to two metering bins where it is weighed and fed into the gasifier.

Delivery and Receiving: The fuel from off-site locations is shipped into the longterm Fuel Storage Building into which the access to the trucks is provided by a lightweight and quick-opening automatic door. The side-dump trucks then drop the fuel into a fuel receiving bin. In addition to delivering fuel directly into the receiving bin, trucks also simultaneously deliver fuel at another location within the building for storage purpose. A number of dozers then spread and store the fuel uniformly. 
Shredding and Size Reduction: The fuel delivered directly to the receiving bin is then dropped to a shredder through a vibrating hopper and a variable opening gate. Since the fuel delivery and receiving process operates 10 hours a day for 5 days a week, the dozers feed fuel into the bin during the remaining hours of the week. This is a non-automatic operation, and requires operator action during 118 hours of a 168-hour week, i.e., for more than 70 percent of the time the operation is manual.

The Fuel Storage Building is $45 \mathrm{~m} \times 30 \mathrm{~m}$ ( $150 \mathrm{ft}$ by $100 \mathrm{ft}$.) The receiving hopper, gate, and the shredder are located below the grade level.

Transfer to Short-Term Storage: Shredded fuel is then transferred to the Day Silo for short-term storage through a belt conveyor.

Metering and Feeding to Gasifier: The fuel from the Day Silo is fed to two vibrating hoppers each with a variable opening gate. The gates allow the fuel to drop to two conveyor belts. The two conveyor belts transfer the fuel to two metering bins for weighing and finally feeding the gasifier.

\subsubsection{Permit Issues}

Based on the past plant operating data for the Monticello plant Unit 1, the total Heat Input to the boiler from coal and lignite, as reported for 1998 was $44.6 \times 10^{\wedge} 12 \mathrm{~kJ}\left(44.3 \times 10^{\wedge} 6 \mathrm{MMBtu}\right)$. Assuming similar level of heat input under cofiring, the following figure 3-6 provide expected heat input to the boiler from coal and poultry litter.

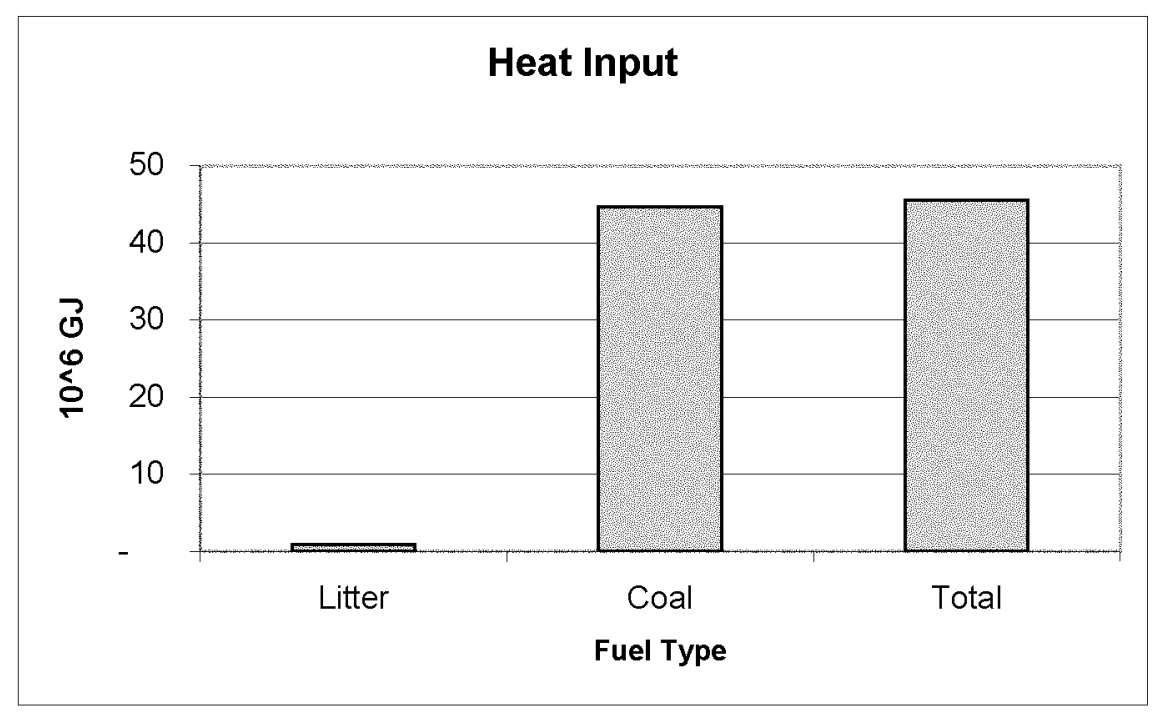

Figure 3-6 Heat input to the boiler with cofiring 
NOx and SOx Emissions: Figure 3-7 provides as reported NOx and SOx emissions from the Monticello unit 1 during 1998. Since, heat input from poultry litter as shown above is insignificant compared with the heat input from primary fuel, lignite and coal, the biomass cofiring is not going to make any significant impact on the overall plant emissions. Hence, at present, no separate calculations are carried out to determine actual emissions under cofiring. As far as the permit issues are concerned, no changes to the permit are expected and no reissue of permit is required. The gasification based cofiring can be conducted under the existing permit.

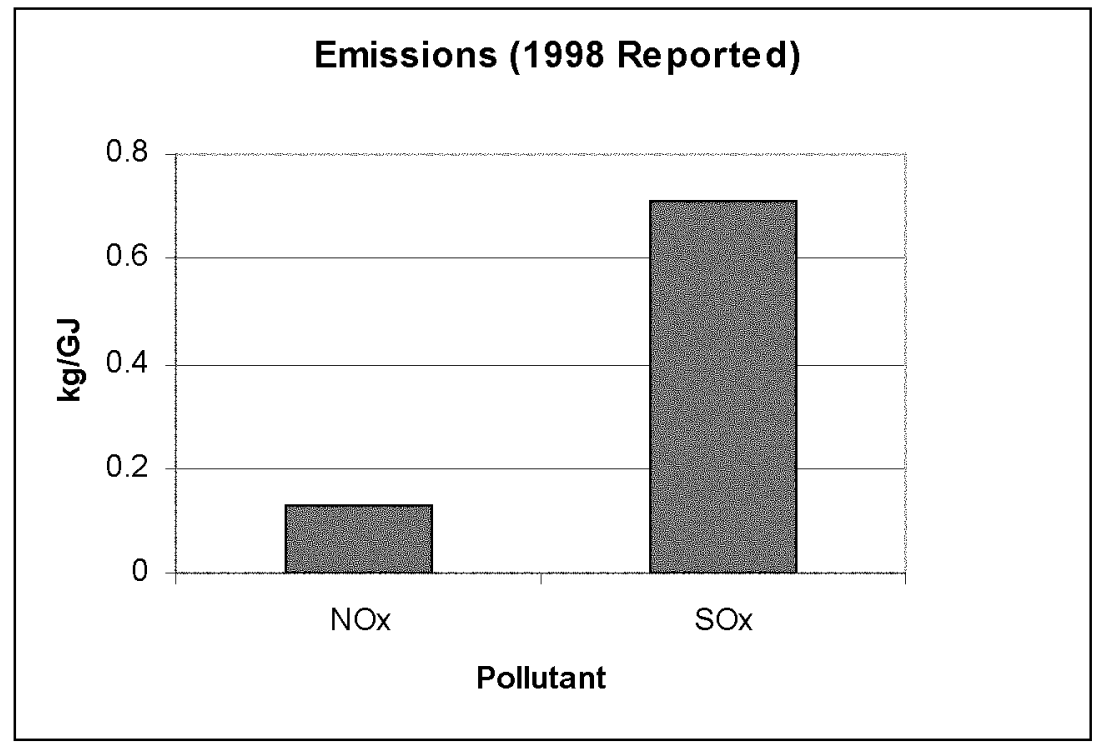

Figure 3-7 Reported NOx and SOx emissions at Monticello Plant

Chlorine: As discussed under WKE's Reid plant, chlorine will not be an issue under cofiring.

Heavy Metals: Due to organic nature of the litter, there is very little, if any heavy metals. Elemental analyses of the litter and ash samples have not detected any mercury and insignificant amount of arsenic, etc. Hence, there is no burden of heavy metals from the gases entering the boiler from the gasifier.

Odor: By storing the litter in the enclosed building or the silos and using enclosed belt or pneumatic conveying and recycling this air as underfire combustion air, the project is expected to eliminate or minimize the odor from the litter.

Poultry litter is a renewable energy resource. The Monticello plant will be able to reduce its fossil fuel consumption by $1 \sim 2 \%$ and can claim a reduction in greenhouse emissions $\left(\mathrm{CO}_{2}\right)$ from the boiler. 


\subsubsection{Fuel Contracts}

Contacts with local haulers and Pilgrims' Pride were established by TXU for the Monticello case. Pilgrims Pride has shown interest and is willing to work with the project and TXU. For economic analysis $\$ 8 /$ ton for poultry litter is used for the Monticello case.

\subsubsection{Major Equipment List}

A preliminary equipment list is prepared for the litter receiving, storage and transport to the gasifier island based on concepts described above. Primenergy prepared the gasifier island equipment list in Table 3-12 and the cost estimate.

Material handling equipment list was developed using input from vendors and from site layout. Due to larger size and site layout, consideration was given to both long term on site storage as well as partially and fully automated system as described in Section 3.2.6.

The material handling equipment list in Table 3-13 was developed using input from the vendors and from the site layout. 
Table 3-12 Gasifier Island Equipment List

\begin{tabular}{|c|c|c|c|}
\hline Equipment & Quantity & Size/ Capacity & $\begin{array}{l}\text { Supplier/ } \\
\text { Vendor }\end{array}$ \\
\hline Fuel Feed Rotary Valve & 2 & $7.5 \mathrm{t} / \mathrm{h}-3.75 \mathrm{~kW}$ & Primenergy \\
\hline Fuel Infeed Auger & 2 & $3.75 \mathrm{~kW}$ & \\
\hline KC-18 Gasifier & 2 & $7.5 \mathrm{t} / \mathrm{h}$ each & \\
\hline Agitator & 2 & $3.75 \mathrm{~kW}$ & \\
\hline Ash Discharge Auger \#1 for each gasifier & 2 & $2 . \mathrm{t} / \mathrm{h}-2.25 \mathrm{~kW}$ & \\
\hline Ash Discharge Auger \#2 for each gasifier & 2 & 2. $\mathrm{t} / \mathrm{h}-2.25 \mathrm{~kW}$ & \\
\hline Ash Cooling Auger & 2 & 2. $\mathrm{t} / \mathrm{h}-3.75 \mathrm{~kW}$ & \\
\hline Ash Silo & 1 & $5.5 \mathrm{~m} \mathrm{D} \times 10 \mathrm{~m} \mathrm{H}$ & \\
\hline Underfire Air Fan & 2 & $180 \mathrm{~m}^{3} / \mathrm{Min}-30 \mathrm{~kW}$ & \\
\hline Cooling Water Pump & 3 & $250 \mathrm{l} / \mathrm{min}-7.5 \mathrm{~kW}$ each & \\
\hline Hot Gas Filter & 2 & $750 \mathrm{C}, 300 \mathrm{~m}^{3} / \mathrm{Min}$ & \\
\hline Fly Ash Discharge Valve & 4 & $0.7 \mathrm{~kW}$ each & \\
\hline Final Ash Conveyor & 2 & $7.5 \mathrm{~kW}$ & \\
\hline ID Fan & 2 & $750 \mathrm{C}, 300 \mathrm{~m}^{3} / \mathrm{Min}, 185 \mathrm{~kW}$ & \\
\hline Overfire Combustion Chamber & 2 & Refractory Lined - & \\
\hline Overfire Air Fan & 2 & $20 \mathrm{C}, 35 \mathrm{~m}^{3} / \mathrm{Min}, 20 \mathrm{~kW}$ & \\
\hline Air Compressor & 1 & $250 \mathrm{~m}^{3} / \mathrm{Min}, 100 \mathrm{~kW}$ & \\
\hline Combustion Air Heater & 2 & $2.5 \mathrm{~m} \times 3.7 \mathrm{~m}$ & \\
\hline Refractory Lined Piping & As Req'd. & & \\
\hline Expansion Joints for boiler Penetrations & 8 & $510 \mathrm{~mm}$ diameter each & \\
\hline Pipe Supports & As Req'd & & \\
\hline MCC Unit & 1 & 40 CB Minimum & \\
\hline DCS Unit & 1 & 200 Analog, 75 Digital I/O & \\
\hline Operator Consoles & 2 & $\mathrm{~N} / \mathrm{A}$ & \\
\hline
\end{tabular}

Note: Primenergy will package the entire gasification island system and equipment. Hence, individual vendors for major equipment are not listed. 
Table 3-13 Material handling equipment list

\begin{tabular}{|c|c|c|c|}
\hline Equipment & Qty & Size/Capacity & Potential Manufacturer \\
\hline Fuel Storage Building & 1 & $150^{\prime} \times 120^{\prime}$ & Local construction contractors \\
\hline Bull Dozer & 2 & 20 tons per hour front end loader & CAT, John Deer, IH \\
\hline Trucks - side dump & 3 & 20 ton capacity; $40^{\prime}$ long & Various \\
\hline Receiving Bin (from truck) & 1 & Concrete $-30^{\prime} \times 10^{\prime} \times 5^{\prime}$ high & Local construction contractors \\
\hline Feed Hopper (from Bin) & 1 & Steel - as shown & On site erection per vendor dwgs \\
\hline Hopper Vibrator & 3 & Motorized & Martin Engineering, Chicago, IL \\
\hline \begin{tabular}{|l}
$\begin{array}{l}\text { Motorized Slide Gate (from } \\
\text { Hopper) }\end{array}$ \\
\end{tabular} & 3 & $\begin{array}{l}\text { 1- for receiving bin hopper } \\
2 \text { - for day silo hoppers }\end{array}$ & $\begin{array}{l}\text { PEBCO (Cleveland Armstrong), } \\
\text { Paducah, KY }\end{array}$ \\
\hline Shredder & 1 & $\begin{array}{l}20 \text { tons per hour; reduced to max size } \\
1 / 4 "\end{array}$ & ROXON - SANDVIK, Finland \\
\hline Inclined Conveyor Belt & 1 & $\begin{array}{l}300^{\prime} \text { long; inclined at } 22 \text { degrees; } \\
48 " \mathrm{~W}\end{array}$ & $\begin{array}{l}\text { Nordberg, Milwaukee, WI. } \\
\text { Newton Conveyors, Inc. } \\
\text { Cleburne, TX }\end{array}$ \\
\hline $\begin{array}{l}\text { Bucket Elevator (with Belt) } \\
\text { (not used) }\end{array}$ & 1 & $16^{\prime \prime}$ wide $x 130^{\prime}$ long & $\begin{array}{l}\text { Newton Conveyors, Inc. } \\
\text { Cleburne, TX }\end{array}$ \\
\hline Day Storage Silo & 1 & $25^{\prime}$ dia x 25' tall - steel construction & \\
\hline Hopper & 2 & Steel - as shown & \\
\hline Horizontal Conveyor Belt & 2 & $\begin{array}{l}\text { Each - } 10 \text { tons per hour; } 36 " \text { wide; } 20 \\
\text { long }\end{array}$ & $\begin{array}{l}\text { Nordberg, Milwaukee, WI. } \\
\text { Newton Conveyors, Inc. } \\
\text { Cleburne, TX }\end{array}$ \\
\hline
\end{tabular}

\subsubsection{Gasification Plant Layout}

After consultation with the plant personnel and TXU management, it was decided that two feasible locations for the gasifier island should be given consideration. The primary location is north side of the unit 1 boiler near the existing document control center. This location is about $250 \mathrm{~m}\left(800^{\prime}\right)$ from the boiler. Drawings for the plant layout and gas piping to the boiler are provided in appendix B. Alternate arrangement is to locate the gasifier island in the northeast corner of the site, near the existing ash disposal and east of the railroad tracks. This arrangement will increase the gas piping length to $600 \mathrm{~m}$ (2000'). Except for the piping layout, the major equipment arrangement will remain the same. No separate drawings for alternate arrangement are developed. 


\section{Economic Analysis}

\subsection{Reid Plant Case}

\subsubsection{Capital and O\&M Cost Estimates}

Primenergy developed capital cost for the gasification plant and supporting equipment required for the gasifier. Nexant developed detailed concept for the fuel receiving, storage and transport to the gasifier. Cost for this system was estimated by contacting vendors and requesting written quotes. Installation cost was established based on bulk material estimates and vendor input. Table 4-1 provide summary of the capital cost for three different material handling system configurations.

Table 4-1 Capital Cost Estimates for the Fuel Storage and Conveying

\begin{tabular}{|c|c|c|c|c|c|c|}
\hline \multirow{2}{*}{\begin{tabular}{|c|} 
Material Handling System \\
Conveying System \\
\end{tabular}} & \multicolumn{6}{|c|}{$8 \mathrm{t} / \mathrm{h}$ System } \\
\hline & \multicolumn{2}{|c|}{ Mechanical } & \multicolumn{2}{|c|}{ Pneumatic } & \multicolumn{2}{|c|}{$\begin{array}{c}\text { Alternate } \\
\text { Mechanical }\end{array}$} \\
\hline Truck Unloading & $\$$ & 65,220 & $\$$ & 75,000 & $\$$ & 200,969 \\
\hline Long Term Storage & $\$$ & 433,170 & $\$$ & 450,000 & $\$$ & 882,716 \\
\hline Day Storage & $\$$ & 94,437 & $\$$ & 90,000 & $\$$ & 228,911 \\
\hline Additional Equipment/Parts & $\$$ & 94,587 & $\$$ & 60,000 & $\$$ & 99,000 \\
\hline Conveying & $\$$ & 375,000 & $\$$ & 250,000 & $\$$ & 434,710 \\
\hline Trench construction/ Cover & $\$$ & 130,000 & $\$$ & - & $\$-$ & \\
\hline On Site Construction & $\$$ & 481,000 & $\$$ & 250,000 & $\$$ & 258,456 \\
\hline Total & $\$$ & $1,673,414$ & & $, 175,000$ & $\$$ & $2,104,762$ \\
\hline
\end{tabular}

The following table 4-2 is the total capital cost for the entire system, including boiler modification and on site construction management for WKE case.

Table 4-2 Total Capital Cost for WKE's Case

\begin{tabular}{|c|c|c|}
\hline Item & Cost \$ & Cost \$ \\
\hline Conveying Systems & Mechanical & Pneumatic \\
\hline $\begin{array}{l}\text { Primenergy Equipment and } \\
\text { Site Installation }\end{array}$ & $6,951,847$ & $\$ 6,951,847$ \\
\hline Material Handling Equipment & $1,673,414$ & $\$ 1,175,000$ \\
\hline Boiler Penetrations/ Other Eng. & 250,000 & 250,000 \\
\hline Contingency ( $5 \%$ of above) & 443,763 & 418,842 \\
\hline $\begin{array}{l}\text { WKE Construction Management } \\
\text { (12 week Construction Phase) }\end{array}$ & 144,000 & $\$ \quad 144,000$ \\
\hline Total Capital Cost & $9,463,024$ & $\$ 8,939,689$ \\
\hline
\end{tabular}

Table 4-3 provides an estimate for the fuel and O\&M cost for the gasifier system. 
Gasification Based Biomass Cofiring, Phase I DOE NETL Project DE-FC26-00NT40898

Table 4-3 Operation, Maintenance and Fuel Cost Estimate - WKE Case

\begin{tabular}{|c|c|c|c|c|}
\hline Item & & Units & Cost & Basis \\
\hline Gasifier Fuel \& Ash & & & & \\
\hline Poultry Litter & $7.45(8.20)$ & t/h (tons/hr) & $\$ 10.90(\$ 12.00)$ & $\$ / t$ (\$/ton) \\
\hline Heating Value (LHV) & $9,768 \quad(4,200)$ & $\mathrm{kJ} / \mathrm{kg}(\mathrm{Btu} / \mathrm{lb})$ & $\$ 1.12(\$ 1.43)$ & $\$ / G J$ (\$/MMBtu) \\
\hline Natural Gas & $20.9(46)$ & $\mathrm{kg} / \mathrm{h}(\mathrm{lbs} / \mathrm{hr})$ & & \\
\hline Heating Value (LHV) & $50,007 \quad(21,502)$ & $\mathrm{kJ} / \mathrm{kg}(\mathrm{Btu} / \mathrm{lb})$ & $\$ 5.68(\$ 6.00)$ & $\$ / G J$ (\$/MMBtu) \\
\hline Nominal Ash in Litter & $20-26$ & $\%$ & & \\
\hline Ash Produced (@26\% ash) & $1.96 \quad(2.16)$ & t/h (tons/hr) & $\$ 1.82(\$ 2.00)$ & $\$ / t$ (\$/ton) \\
\hline Credit for sale of Ash (year 3+) & & & $(\$ 5.45)((\$ 6.00))$ & $\$ /$ t (\$/ton) \\
\hline Boiler Availability Factor & $70 \%$ & $\% /$ year & (assumed) & \\
\hline Gasifier Capacity Factor & $90 \%$ & $\% /$ year & & \\
\hline Total Poultry Litter Usage & $41,091 \quad(45,254)$ & tpy (tons/yr) & $\$ 543,050$ & /year Litter Cost \\
\hline Total NG Usage & $115,255 \quad(253,865)$ & $\mathrm{kg} / \mathrm{y}(\mathrm{Ibs} / \mathrm{y})$ & $\$ 32,752$ & /year NG Cost \\
\hline Total Ash Produced \& cost & $10,814 \quad(11,910)$ & tpy (tons/yr) & $\$ 23,819$ & $\begin{array}{c}\text { /year } \\
\text { (year }(1,2)\end{array}$ \\
\hline Ash Credits (year 3+) & & & $(\$ 71,457)$ & $\begin{array}{c}\text { lyear } \\
(\text { year } 3+)\end{array}$ \\
\hline Net Gasifier Output Eq. kWe & $5,238.9$ & kWe & & \\
\hline Total Power Produced & $28,912,496$ & $\mathrm{kWh} / \mathrm{y}$ & & \\
\hline Fuel Cost (year 1,2) & 0.021 & & $\$ 599,621$ & /year (year 1,2) \\
\hline Fuel Cost (year 3+) & 0.017 & & $\$ 504,344$ & /year (year 3+) \\
\hline \multicolumn{5}{|l|}{ Operation } \\
\hline Operation Manpower & 2.50 & man-year & $\$ 15.00$ & $/ \mathrm{hr}$ \\
\hline $\mathrm{OH}$ Multiplier & 1.50 & & $\$ 22.50$ & $/ \mathrm{hr}$ \\
\hline Operation Payroll Cost & 0.004 & $\$ / \mathrm{kWh}$ & $\$ 117,000$ & /year \\
\hline \multicolumn{5}{|l|}{ Utility } \\
\hline Water & $3.41(54.02)$ & l/s (gpm) & $\$ 0.53(\$ 2.00)$ & $\begin{array}{c}\$ / k l \\
(\$ / 1000 \text { gal })\end{array}$ \\
\hline \multicolumn{5}{|l|}{ Air (Accounted as Aux Load) } \\
\hline \multicolumn{5}{|l|}{ Electricity (-do-) } \\
\hline Utility Cost & 0.001 & $\$ / \mathrm{kWh}$ & $\$ 35,774$ & lyear \\
\hline Annual Maintenance & 0.005 & $\$ / k W h$ & $\$ 144,562$ & /year \\
\hline Total O\&M Cost & 0.010 & $\$ / \mathrm{kWh}$ & $\$ 297,337$ & /year \\
\hline \multicolumn{5}{|l|}{ Operating Cost of Power } \\
\hline Fuel \& O\&M Cost (year 1,2) & 0.031 & $\$ / k W h$ & $\$ 896,957$ & /year \\
\hline Fuel \& O\&M Cost (year $3+$ ) & 0.028 & $\$ / k W h$ & $\$ 801,681$ & /year \\
\hline
\end{tabular}

The delivered litter cost was developed by contacting local farmers and also requesting written quotes from local haulers who traditionally haul litter for the farmers. The maintenance cost was based on EPRI guideline for typical power plant with 5 mills per $\mathrm{kWh}$ produced. To minimize operating cost of the gasifier, the controls are to be integrated with the existing control room. Thus the plant 
operating personnel can operate the gasifier from the control room with no additional personnel. The total burden on the plant operation, including material handling for the poultry litter and ash removal was estimated at 21/2 men equivalent.

Two separate estimates were developed. It is assumed that during the first two years of operation, no market for the gasifier ash is available. Thus $\$ 2 /$ ton of disposal cost was assigned to the electricity production cost. Since, the ash is a valuable P\&K source, it can be sold to local farmers as a supplemental fertilizer. Nominal revenue of $\$ 6 /$ ton was assigned for year 3 analyses.

As shown in the above table, the fuel and O\&M cost for the first two years of operation is calculated at $3.1 \mathrm{c} / \mathrm{kWh}$ and for subsequent years it is $2.8 \mathrm{c} / \mathrm{kWh}$. This cost can be considerably reduced, if the litter can be procured at lower or negative price and higher price can be commended for the ash. A sensitivity analyses based on these and other financial factors is provided in the Appendix.

\subsubsection{Financial Pro Forma}

The levelized cost of the electricity is calculated using financial parameters in table 4-4:

\section{Table 4-4 Input Financial Parameters}

\begin{tabular}{|l|rl|}
\hline Financial Factors & & \\
\hline Inflation rate (annual) & 3 & $\%$ \\
Fuel escalation rate (annual) & 0 & $\%$ \\
Start of construction & 2003 & \\
Years of construction & 1 & \\
Debt & 80 & $\%$ \\
Return on Debt & 7.5 & $\%$ \\
Return on Equity & 12 & $\%$ \\
Base year (for economic reporting) & 2002 & \\
Book life & 20 & years \\
Capacity factor (0.70x0.90=0.63) & 63 & $\%$ \\
\hline
\end{tabular}


Table 4-5 Levelized Cost of Electricity for WKE Case

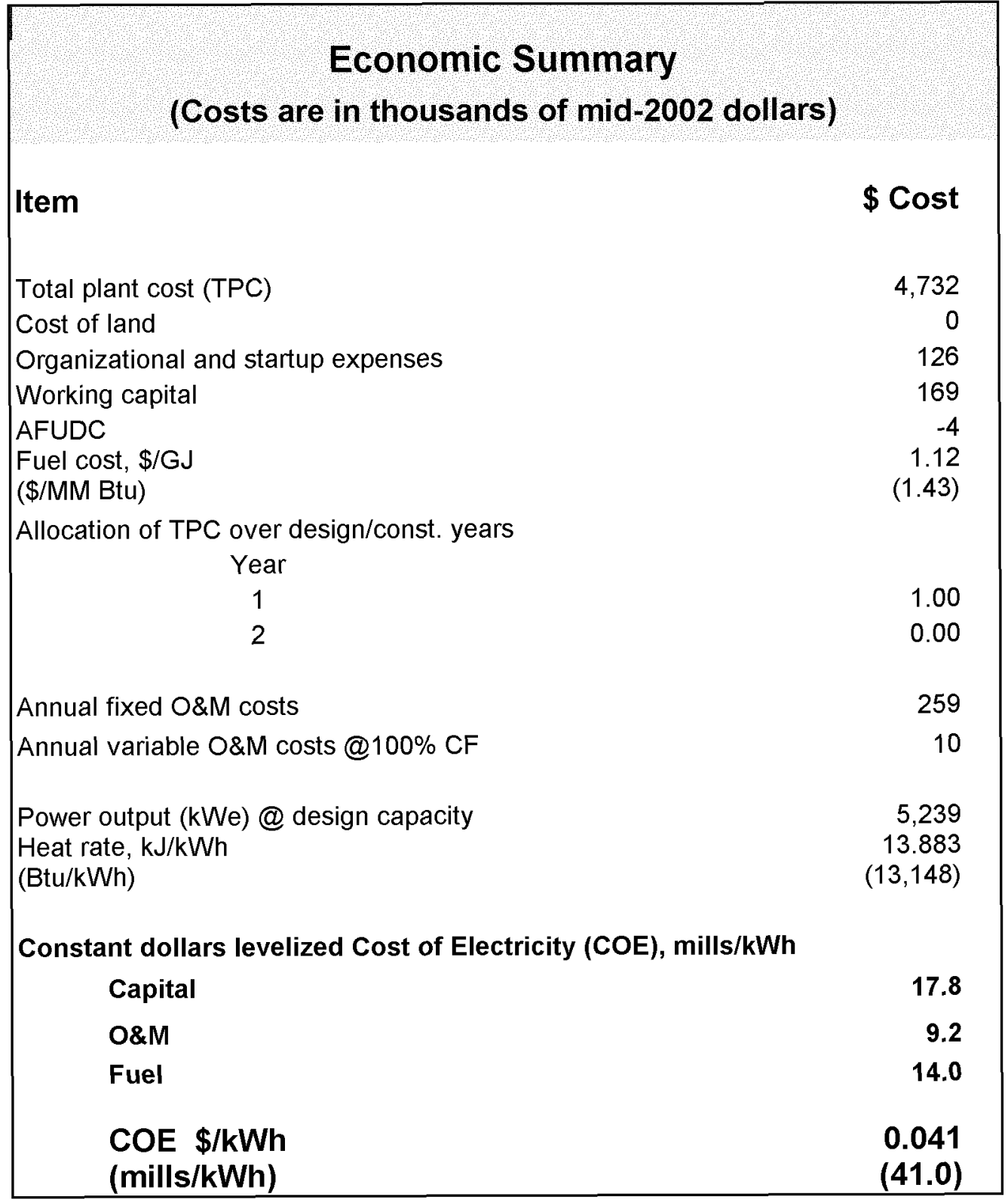

\subsubsection{Sensitivity Analysis for Reid Plant Case}

The price of electricity produced from the biomass gasifier is dependent upon capital cost, fuel cost and fixed O\&M cost for the gasification operation. The table 4-6 on next page provides sensitivity analysis for changes in some of these parameters. 
Table 4-6 COE Sensitivity Analyses for Reid Case

\begin{tabular}{|c|c|c|c|c|c|c|c|c|c|c|}
\hline Case & $\begin{array}{c}\text { Litter } \\
\text { Cost }\end{array}$ & $\begin{array}{c}\text { Ash } \\
\text { Credits }\end{array}$ & $\begin{array}{c}\text { Capital } \\
\text { Cost }\end{array}$ & WKE Cost & Interest & Period & Fuel & O\&M & Capital & Total \\
\hline $\begin{array}{c}\text { Base } \\
\text { Case }\end{array}$ & 12 & $(6)$ & $\$ 9,500,000$ & $\$ 4,750,000$ & $7.5 \%$ & 10 & 1.74 & 1.03 & 2.39 & 5.17 \\
\hline 2 & 8 & $(6)$ & $\$ 9,500,000$ & $\$ 4,750,000$ & $7.5 \%$ & 10 & 1.12 & 1.03 & 2.39 & 4.54 \\
\hline 3 & 10 & $(8)$ & $\$ 9,500,000$ & $\$ 4,750,000$ & $7.0 \%$ & 15 & 1.35 & 1.03 & 1.80 & 4.18 \\
\hline 4 & 12 & $(10)$ & $\$ 9,500,000$ & $\$ 4,750,000$ & $7.0 \%$ & 15 & 1.58 & 1.03 & 1.80 & 4.41 \\
\hline 5 & 6 & $(12)$ & $\$ 8,900,000$ & $\$ 4,450,000$ & $7.0 \%$ & 15 & 0.56 & 1.03 & 1.69 & 3.28 \\
\hline 6 & 8 & $(12)$ & $\$ 8,900,000$ & $\$ 4,450,000$ & $7.5 \%$ & 10 & 0.87 & 1.03 & 2.24 & 4.14 \\
\hline 7 & 10 & $(14)$ & $\$ 8,900,000$ & $\$ 4,450,000$ & $7.0 \%$ & 10 & 1.10 & 1.03 & 2.19 & 4.32 \\
\hline 8 & 12 & $(16)$ & $\$ 8,900,000$ & $\$ 4,450,000$ & $7.0 \%$ & 10 & 1.33 & 1.03 & 2.19 & 4.55 \\
\hline
\end{tabular}

One of the variables for the cost of electricity is cost of litter. The other variable is disposal cost of ash. As previously mentioned, the ash from the gasifier can be a useful source as a P\&K based fertilizer. If the ash was sold as a fertilizer, it will contribute toward reducing the cost of electricity production. The figure 4-1 provides impact of litter cost and benefit of ash credits. 
Gasification Based Biomass Cofiring, Phase I

DOE NETL Project DE-FC26-00NT40898

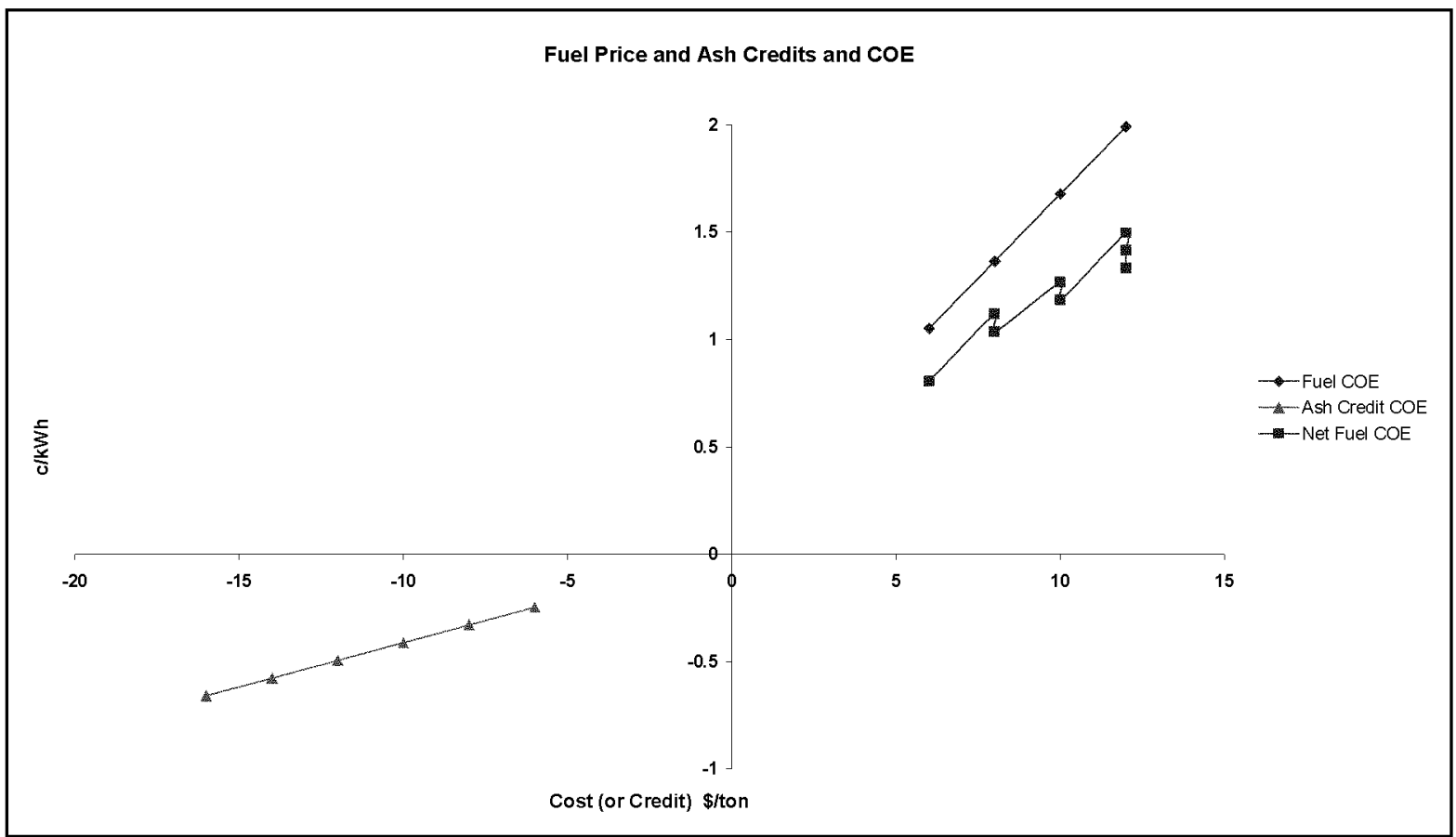

Figure 4-1 COE Sensitivity to Fuel Price and Ash Credit 


\subsection{Monticello Unit 1 Case}

\subsubsection{Capital and O\&M Cost Estimate}

As in the case of Reid plant, Primenergy developed capital cost for the gasification plant and supporting equipment required for the gasifier. Nexant developed detailed concept for the fuel receiving, storage and transport to the gasifier. Cost of these systems was estimated by contacting vendors and requesting written quotes. Installation cost was established based on bulk material estimates and vendor input.

Table 4-7 Capital Cost Estimates for Fuel Storage and Conveying

\begin{tabular}{|c|c|c|}
\hline Material Handling Cost Estimate & \multicolumn{2}{|c|}{$\begin{array}{c}\text { Mechanical } \\
\text { System }\end{array}$} \\
\hline Major Equipment & $\$$ & 672,800 \\
\hline Bulk Material & $\$$ & 269,200 \\
\hline Direct Sub Contract & $\$$ & 438,300 \\
\hline Direct Labor & $\$$ & 287,200 \\
\hline Sales Tax@8\% Freight @3\% & $\$$ & 103,600 \\
\hline Total Direct Costs & $\$$ & $1,771,100$ \\
\hline Field Indirect @100\% Labor & $\$$ & 287,200 \\
\hline Total Field Cost & $\$$ & $2,058,300$ \\
\hline Home Office Cost @ 12\% & $\$$ & 247,000 \\
\hline Escalation (none assumed) & $\$$ & - \\
\hline Total Mat. Handling Cost w/o Escalation & $\$$ & $2,305,300$ \\
\hline Contingency@10\% & $\$$ & 230,530 \\
\hline Total Estimate & $\$$ & $2,535,830$ \\
\hline
\end{tabular}

The following is the total capital cost for the entire system, including boiler modification and on site construction management for the TXU Monticello case. The Monticello case was analyzed as a commercial unit. 
Table 4-8 Total Capital Cost for the Monticello Plant

\begin{tabular}{|l|lc|}
\hline \multicolumn{1}{|c|}{ Item } & \$ Cost Estimate \\
\hline Primenergy Equipment & & \\
\hline Material Handling Equipment & $\$ 11,000,000$ \\
\hline Boiler Penetrations/ Other Eng. & $\$$ & $2,535,830$ \\
\hline Contingency @ 5\% of above & $\$$ & 400,000 \\
\hline $\begin{array}{l}\text { TXU Construction Management } \\
\text { (16 week Construction Phase) }\end{array}$ & $\$$ & 696,792 \\
\hline Total Capital Cost & $\$$ & 250,000 \\
\hline
\end{tabular}

Table 4-9 provides an estimate for the fuel and O\&M cost for the gasifier system.

As in the WKE case, the delivered litter cost was developed by contacting local farmers and also requesting written quotes from local haulers who traditionally haul litter for the farmers. The maintenance cost was based on EPRI guideline for typical power plant with 5 mills per $\mathrm{kWh}$ produced. To minimize operating cost of the gasifier, the controls are to be integrated with the existing control room. Thus the plant operating personnel can operate the gasifier from the control room with no additional personnel. The total burden on the plant operation, including material handling for the poultry litter and ash removal was estimated at $21 / 2$ men equivalent.

Two separate estimates were developed. It is assumed that during the first two years of operation, no market for the gasifier ash is available. Thus $\$ 2 /$ ton of disposal cost was assigned to the electricity production cost. Since, the ash is a valuable P\&K source, it can be sold to local farmers as an supplemental fertilizer. Nominal revenue of $\$ 6 /$ ton was assigned for year 3 analyses.

As shown in the table 4-9 below, the fuel and O\&M cost for the first two years of operation is calculated at $3.1 \mathrm{c} / \mathrm{kWh}$ and for subsequent years it is $2.8 \mathrm{c} / \mathrm{kWh}$. This cost can be considerably reduced, if the litter can be procured at lower or negative price and higher price can be commended for the ash. A sensitivity analyses based on these and other financial factors is provided in the Appendix B TXU Case. 
Gasification Based Biomass Cofiring, Phase I DOE NETL Project DE-FC26-00NT40898

Table 4-9 Operation, Maintenance and Fuel Cost Estimate - Monticello Case

\begin{tabular}{|c|c|c|c|c|}
\hline Item & & Units & Cost & Basis \\
\hline \multicolumn{5}{|l|}{ Gasifier Fuel and Ash } \\
\hline Poultry Litter & $14.53(16.00)$ & $\mathrm{t} / \mathrm{h}$ (tons/hr) & $\$ 7.26(\$ 8.00)$ & $\$ / t(\$ /$ ton $)$ \\
\hline Heating Value (LHV) & $9,768(4,200)$ & $\mathrm{kJ} / \mathrm{kg}(\mathrm{Btu} / \mathrm{lb})$ & $\$ 0.74(\$ 0.95)$ & \$/GJ (\$/MMBtu) \\
\hline Natural Gas & $0 \quad(0)$ & $\mathrm{kg} / \mathrm{h}(\mathrm{lbs} / \mathrm{hr})$ & & \\
\hline Heating Value (LHV) & $50,007 \quad(21,502)$ & $\mathrm{kJ} / \mathrm{kg}(\mathrm{Btu} / \mathrm{lb})$ & $\$ 5.68(\$ 6.00)$ & $\$ / G J$ (\$/MMBtu) \\
\hline Nominal Ash in Litter & $18 \sim 23$ & $\%$ & & \\
\hline Ash Produced (@23\% Level) & $3.34 \quad(3.68)$ & t/h (tons/hr) & $\$ 1.82(\$ 2.00)$ & $\$ / t$ (\$/ton) \\
\hline Credit for sale of ash (year $3+$ ) & & & $(\$ 5.45)((\$ 6.00))$ & $\$ / t$ (\$/ton) \\
\hline Boiler Availability Factor & $80 \%$ & $\% /$ year & (assumed) & \\
\hline Gasifier Capacity Factor & $90 \%$ & $\% /$ year & & \\
\hline Total Poultry Litter Usage & $91,631(100,915)$ & tpy (tons/yr) & $\$ 807,322$ & /year \\
\hline Total NG Usage & $0 \quad(0)$ & $\mathrm{kg} / \mathrm{y}(\mathrm{lbs} / \mathrm{y})$ & $\$ 0$ & /year \\
\hline Total Ash Produced & $21,075 \quad(23,210)$ & tpy (tons/yr) & $\$ 46,421$ & $\begin{array}{c}\text { /year } \\
\text { (year } 1,2)\end{array}$ \\
\hline Ash Credits (year 3+) & & & $(\$ 139,263)$ & $\begin{array}{c}1 \text { year } \\
\text { (year 3+) }\end{array}$ \\
\hline Total Gasifier Output Eq. kWe & $12,782.7$ & $\mathrm{kWe}$ & & \\
\hline Total Power Produced & $80,622,887$ & $\mathrm{kWh} / \mathrm{y}$ & & \\
\hline Fuel Cost (year 1,2) & 0.011 & & $\$ 853,743$ & lyear (year 1,2) \\
\hline Fuel Cost (year 3+) & $\$ \quad 0.008$ & & $\$ 668,059$ & /year (year $3+$ ) \\
\hline \multicolumn{5}{|l|}{ Operation } \\
\hline Operation Manpower & 3.00 & man-year & $\$ 20.00$ & $/ \mathrm{hr}$ \\
\hline $\mathrm{OH}$ Multiplier & 1.50 & & $\$ 30.00$ & $/ \mathrm{hr}$ \\
\hline Operation Payroll Cost & $\$ \quad 0.002$ & $\$ / k W h$ & $\$ 187,200$ & /year \\
\hline \multicolumn{5}{|l|}{ Utility } \\
\hline Water & $3.41 \quad(54.02)$ & I/s (gpm) & $\$ 0.53(\$ 2.00)$ & $\begin{array}{c}\$ / \mathrm{kl} \\
(\$ / 1000 \mathrm{gal})\end{array}$ \\
\hline \multicolumn{5}{|l|}{ Air (Accounted as Aux Load) } \\
\hline \multicolumn{5}{|l|}{ Electricity (-do-) } \\
\hline Utility Cost & 0.001 & $\$ / \mathrm{kWh}$ & $\$ 40,885$ & /year \\
\hline Annual Maintenance & 0.005 & $\$ / k W h$ & $\$ 403,114$ & /year \\
\hline Total O\&M Cost & $\$ \quad 0.008$ & $\$ / \mathrm{kWh}$ & $\$ 631,199$ & /year \\
\hline \multicolumn{5}{|l|}{ Operating Cost of Power } \\
\hline Fuel \& O\&M Cost (year 1,2) & $\$ \quad 0.018$ & $\$ / \mathrm{kWh}$ & $\$ 1,484,942$ & /year \\
\hline Fuel \& O\&M Cost (year 3+) & $\$ \quad 0.016$ & $\$ / k W h$ & $\$ 1,299,258$ & /year \\
\hline
\end{tabular}




\subsubsection{Financial Pro Forma}

Table 4-10 Levelized Cost of Electricity for Monticello Case

\begin{tabular}{|c|c|}
\hline \multicolumn{2}{|c|}{$\begin{array}{l}\text { Economic Summary } \\
\text { (Costs are in thousands of mid-2002 dollars) }\end{array}$} \\
\hline Item & \$ Cost \\
\hline Total plant cost (TPC) & 14,883 \\
\hline Cost of land & 0 \\
\hline Organizational and startup expenses & 355 \\
\hline Working capital & 263 \\
\hline AFUDC & 384 \\
\hline Fuel cost, \$/MM Btu & 0.95 \\
\hline \multicolumn{2}{|l|}{ Allocation of TPC over design/const. years } \\
\hline 1 & 0.12 \\
\hline 2 & 0.88 \\
\hline 3 & 0.00 \\
\hline Annual fixed O\&M costs & 587 \\
\hline Annual variable O\&M costs @100\% CF & 14 \\
\hline Power output (kWe) @ design capacity & 12,783 \\
\hline Heat rate, $\mathrm{kJ} / \mathrm{kWh}(\mathrm{Btu} / \mathrm{kWh})$ & $11,101(10,514)$ \\
\hline \multicolumn{2}{|c|}{ Constant dollars levelized Cost of Electricity (COE), mills/kWh } \\
\hline Capital & 19.8 \\
\hline O\&M & 7.4 \\
\hline Fuel & 7.2 \\
\hline COE $\$ / k W h(m i l l s / k W h)$ & $0.0345(34.5)$ \\
\hline
\end{tabular}




\subsubsection{Sensitivity Analysis for Monticello Case}

As mentioned in the Reid plant case, the price of electricity produced from the biomass gasifier is dependent upon capital cost, fuel cost and fixed O\&M cost for the gasification operation. Table 4-11 below provides sensitivity analysis for changes in some of these parameters for the Monticello case.

Table 4-11 COE Sensitivity Analyses for Monticello Case

\begin{tabular}{|c|c|c|c|c|c|c|c|c|c|}
\hline Case & $\begin{array}{c}\text { Litter } \\
\text { Cost } \\
\$ / \text { ton }\end{array}$ & $\begin{array}{c}\text { Ash } \\
\text { Credits } \\
\$ / \text { Ton }\end{array}$ & $\begin{array}{c}\text { Capital Cost } \\
\text { (TXU Cost) }\end{array}$ & $\begin{array}{c}\text { Interest } \\
\%\end{array}$ & $\begin{array}{c}\text { Period } \\
\text { Years }\end{array}$ & $\begin{array}{c}\text { Fuel } \\
\text { c/kWh }\end{array}$ & $\begin{array}{c}\text { O\&M } \\
\text { c/kWh }\end{array}$ & $\begin{array}{c}\text { Capital } \\
\text { c/kWh }\end{array}$ & $\begin{array}{c}\text { Total } \\
\text { c/kWh }\end{array}$ \\
\hline $\begin{array}{c}\text { Base } \\
\text { Case }\end{array}$ & 8 & 0 & $\$ 14,882,622$ & $7.5 \%$ & 10 & 1.00 & 0.78 & 2.69 & 4.47 \\
\hline 2 & 8 & $(6)$ & $\$ 4,882,622$ & $7.5 \%$ & 10 & 0.83 & 0.78 & 2.69 & 4.30 \\
\hline 3 & 8 & 0 & $\$ 14,882,622$ & $7.5 \%$ & 10 & 1.00 & 0.78 & 1.34 & 3.13 \\
\hline 4 & 6 & $(6)$ & $\$ 14,882,622$ & $7.5 \%$ & 10 & 0.58 & 0.78 & 2.69 & 4.05 \\
\hline 5 & 6 & $(6)$ & $\$ 14,882,622$ & $7.5 \%$ & 10 & 0.58 & 0.78 & 1.34 & 2.71 \\
\hline 6 & 4 & 0 & $\$ 14,882,622$ & $7.5 \%$ & 10 & 0.50 & 0.78 & 2.69 & 3.97 \\
\hline 7 & 4 & 0 & $\$ 14,882,622$ & $7.5 \%$ & 10 & 0.50 & 0.78 & 1.34 & 2.63 \\
\hline 8 & 0 & $(6)$ & $\$ 14,882,622$ & $7.5 \%$ & 10 & -0.17 & 0.78 & 2.69 & 3.30 \\
\hline
\end{tabular}

The effect of changes in the litter price and credit for the ash sales will be same for the Monticello plant as in the Reid case. 


\section{Results and Discussion}

Key issues affecting the economics of Biomass gasification cofiring include the capital cost of the gasification island, the costs of retrofitting the utility boiler, any potential boiler derating or loss of capacity as a result of the retrofit, the cost and reliability of the feedstock, and the opportunity costs associated with alternate fuels such as switching to natural gas. The costs of operating a relatively new technology such as the gasifier under cofiring arrangement may be influenced by potentially unforeseen maintenance or component replacement as well as the usual up-keep of such a plant. Similar uncertainties may be associated with the costs of maintaining the retrofitted boiler now being operated in a co-fired mode. With cofiring, there will be the need to integrate the controls for the gasification plant with those of the boiler operation in order to assure good performance and reliable operation from the gasifier and boiler integration. Unforeseen controls issues may also affect the operation of the combined plant and hence the costs of power production.

The broader market for commercializing this gasification technology includes other sites in the US, which have utility boilers and large concentrations of poultry litter production near by. These sites must be numerous enough to attract the industrial investment needed for a profitable business in this technology. The type of business model, varying from direct equipment sales to owning and operating the gasification plant [i.e., selling hardware versus selling product gas] will influence how attractive this market is to the industry. The prospect of more stringent environmental controls coupled with more complete deregulation of the utilities will also impact the economic benefits associated with the co-firing market since more or less utilities will consider converting their boilers to this mode of operation. Finally, the relative flexibility of this gasification approach will impact the extent to which other biomass feedstocks can be gasified in the same manner as poultry litter; the extent to which the gasifier and feedstock handling equipment need to be modified; the change in equipment capital and operating costs associated with such modifications; and the resulting shift in market opportunities associated with these issues.

\subsection{Infrastructure/Fuel Supply and Alternative Fuels}

Gasification has been applied to a wide variety of biomass materials including charcoal wood and wood waste, spent pulping liquor, pulp mill sludge, biosolids (wastewater treatment plant sludge), waste paper, rice hulls, rice straw, switchgrass, sugar cane, bagasse, poultry litter, and other animal wastes. Historically it has been used in close-coupled combustion applications to make steam, and in generation of electrical power largely through firing in internal combustion engines. In recent years efforts also have been made to couple biomass gasification to combustion turbines in integrated gasification-combined cycle (IGCC) applications. 
A key feature of the fuel infrastructure is proximity of the biomass fuel source to the co-firing facility. This helps to reduce the costs of gathering and transporting the biomass fuel to its point of use. In other cases, where the fuel supplier is ready to pay for the haulage costs to avoid related processing and environmental problems, there may even be a financial credit associated with the use of the biomass. Depending on the nature of the feedstock, on-site storage and mass handling of the raw biomass feedstock also require attention in the facility design and maintenance considerations to avoid potential groundwater contamination and stream run-off, as well as odor and pest control.

Other fuel infrastructure problems include consistency of the feedstock properties and rate of delivery. Large fluctuations in either of these factors will require a more flexible design of the gasifier and co-firing features of the boiler with potential escalations in capital and operating costs.

\subsection{Merits of the Project}

Gasification-based co-firing has numerous inherent advantages. It increases the market potential of biomass co-firing. Not only is it applicable to both PC and cyclone boilers, but it is also applicable to many natural gas-fired boilers. If used in conjunction with duct burners between combustion turbine and a heat recovery steam generator (HRSG) it is applicable to combined cycle technology as well. The concept of gasification-based co-firing has the potential to accomplish the following objectives for boiler co-firing:

\subsubsection{Energy Benefits and Impacts}

- Maintain the ability to increase boiler capacity when firing wet coal by adding more Btu's to the primary furnace

- Minimizes the particle size reduction requirement for the biomass as gasifiers typically are capable of using $20 \mathrm{~mm}(3 / 4)$ minus size particles rather than the $6 \mathrm{~mm}\left(1 / 4^{\prime \prime}\right)$ minus size particles associated with co-firing

- Minimize efficiency losses in the boiler by taking those moisture-related losses in the gasifier

\subsubsection{Environmental Benefits and Impacts}

- The gasification approach broadens the range of biomass that can be successfully co-fired with coal or with natural gas, including the use of zero cost and negative cost fuels (for example reduction in the size of biomass is not as stringent for gasification as it is for direct co-firing) 
- Permits deployment with natural gas-fired reburn systems for possible NOx reductions when combusting the producer gas from the gasifier. The over fire reburn system in PC boilers has shown reduction in the NOx from the boiler.

- Continuing the reduction of emissions by reducing the sulfur content of the fuel in the high sulfur coal burning plants.

- Modifying the operating combustion mechanism with gas firing for NOx control, and reducing the particulate loading on existing boiler.

- Biomass co-firing reduces the amount of coal or other fossil fuel used and thereby reduces the net amount of $\mathrm{CO}_{2}$ emission to the atmosphere since the use of biomass is considered to have zero impact on the $\mathrm{CO}_{2}$ atmospheric budget (i.e. plant feed for poultry with subsequent production of poultry litter implies that the $\mathrm{CO}_{2}$ absorbed by the plants is transmitted in part to the litter and in part to the production of meat - consequently more $\mathrm{CO}_{2}$ is absorbed than is released from the biomass during gasification and combustion). This can be considered a $\mathrm{CO}_{2}$ credit under this form of accounting).

\subsubsection{Economic Benefits and Impacts}

The potential hurdles to economic acceptance of the proposed technology include a capital cost commitment to the biomass gasification co-firing technology, uncertainties of the maintenance and operations cost in this application, and the degree to which the reliability and consistency of the feedstock can be assured. The following items represent economic benefits that can potentially offset some of these cost hurdles:

- Keeping the biomass ash separate from the coal ash by gasifier design protects the ability for the plant operator to make ash sales as potential fertilizer.

- The zero or negative cost of biomass (including the benefits of tipping fee avoidance) may lower the cost of plant operation, off-setting to some degree overall cost of electricity (COE) from the biomass gasification plant.

- An actual demonstration of this technology in the future will provide necessary capital and operating cost data to support an accelerated commercialization of the proposed biomass gasification co-firing technology for utility boilers 


\subsubsection{Infrastructure/Fuel Supply Benefits and Impacts}

Biomass gasification projects depend upon availability of cheap fuels. Biomass by itself is a cheap source of fuel and it is generated on year round basis. Therefore supply of biomass is normally not a problem. However, logistics and associated cost of gathering such biomass and delivery to a central location for gasification is the challenge and normally a high cost item. With the low Btu value of the biomass transportation costs can quickly escalate to become a major cost factor.

The WKE application provides a good resolution to all of the infrastructure/fuel supply issues. The Reid plant is ideally located from the fuel supply perspective because of its proximity to large-scale chicken processing plants and the existence of an infrastructure to deliver chickens from area farmers to a central location for processing. Preliminary estimates from the processing plants put the poultry litter in the 50 miles radius of the Reid plant at 180000 to over 200000 tons per year. Further, there is a high degree of consistency and rate of delivery of the litter because of the mass production farming features and growth uniformity of chickens farmed in this manner.

The disposal of the poultry litter has been a significant problem for the local farmers and they have been requesting a regulatory relief from US EPA and US Department of Agriculture. At present the farmers do a partial clean up of the bedding material every 16 18 weeks and go through a springtime cleanup, whereby they completely remove the litter and dispose of it as landfill. If these farmers can find alternatives to land-based disposal, it may be possible to set up long-term fuel supply contracts at low or no cost to the Reid plant. The benefit to the local farmers will be an outlet for their poultry waste as well as more flexibility in scheduling clean-up and removal of the bedding material from their farms.

\subsection{Project Sustainability and Opportunities for Replication}

The chicken processing and other food processing industries are recession proof activities. Hence the supply of poultry litter is assured for the Reid plant as long as nearby chicken processing plants stay in operation. Alternatively, Primenergy gasifiers have been successfully tested with variety of other biomass fuels, such as sawdust pulp mill sludge, rice hulls, biosolids, etc. This flexibility allows the gasifier operators to secure and switch to alternative bio-fuels if poultry litter supply problems develop.

The operation of the co-firing project at the Reid Plant also meets a primary requirement of sustainability; that is WKE already has established a maintenance organization for its switchgrass biomass power plant and plans to generalize their services to include the proposed gasification facility at their Reid plant. 
This project also addresses problems faced by local poultry farmers. The increasing appetite for poultry in North America has increased the concentration of poultry farms and associated litter. Poultry litter has become a disposal problem and runoffs from the fields over-fertilized with litter may carry excessive nutrients to nearby waterways potentially hurting water quality and aquatic life. The proposed gasification system at WKE's Reid Plant will reduce the litter volume while supplying biomass-based energy to the boiler. The greatly reduced volume of ash from the poultry litter will be more economical to transport and sell as high quality fertilizer. Thus the proposed gasification plant will turn a liability into a potential profit center.

This project can also demonstrate excellent replication opportunity throughout the country. The food industries in general and perishable food processors in particular are widely distributed due to the market they serve. The processors have well-established supply and delivery systems for their products as well as for the waste they generate. With these premises, it is safe to assume that there are many other utility power plants that can serve as hosts to gasification systems. With Federal Tax credit under Section 29 for renewable energy, which includes poultry litter, we believe that many utilities will be interested in setting up cooperative agreements with the poultry processors/poultry farmers and in evaluating gasification-based co-firing of biomass.

As a result of these potential benefits we believe that the technology and siting approach proposed here can lead to commercialization of this particular application of biomass co-firing in the future compared to other concepts currently being considered for biomass. However, at present, the economic evaluation based on current price of coal does not lead to commercialization of this technology in North America. 


\section{Conclusions}

This project was proposed to demonstrate technical and economical feasibility of integrated biomass gasification and co-firing applications. The primary focus for the project was to utilize poultry waste as cofiring fuel, although any other biomass that is readily available can be used. Two sites - WKE's Reid plant and TXU's Monticello plants were selected for the feasibility studies. Primary objectives of the Phase I of the study were:

- To foster commercialization of a biomass co-firing technology that utilizes biomass, agricultural waste and farm animal wastes in an environmentally benign, technically practical in an economical application.

- To conduct an evaluation of the technical, regulatory, environmental and economic impacts of gasification based co- firing on existing fossil fuel fired boilers located in the vicinity of significant sources of animal waste and agricultural biomass.

- To identify the potential modifications, if any, required in the proposed gasification, boiler or other integral ancillary systems, to enable effective utilization of the biomass fuels considered.

- To evaluate these factors specifically for the TXU Energy in order to develop engineering cost and schedule estimates for implementing such biomass facilities.

- To implement such a facility at a later date, if the cost estimates and economic evaluations indicate that a useful demonstration of the proposed biomass gasification and co-firing technology can be carried out and replicated at multiple facilities.

The technical evaluations showed the following potential project benefits:

- Environmentally more acceptable renewable and premium power

- Reduced landfill and runoff into waterways

- Potential for reduced fuel cost

- Potential for fertilizer from ash $(\mathrm{P} / \mathrm{K})$

- Gasification external to the boiler offer flexibility in biomass fuels

Gasification-based co-firing has numerous inherent advantages and merits of the proposed projects can be outlined as follows. 
- It increases the market potential of biomass co-firing by creating a more attractive gaseous fuel

- The low Btu gas can be used in various types of boilers including HRSG

- A wide range of different fuels can be gasified

- Biomass co-firing substitutes for coal or other fossil fuels and thereby reduces the net amount of $\mathrm{CO} 2$ emissions to the atmosphere.

However, even though advantages of biomass gasification process is well recognized, and gasification based cofiring does offer a low cost alternative to a stand alone gasification plant, the current economic model is not attractive enough for utilities to consider this option. The primary hurdle in this process is required initial capital cost. From power generator's perspective, new capital investment does not offer any additional kW. Although, gasification based cofiring provides least intrusive alternate fuel for the existing boiler, it does not add to net generation from the plant, and probably may reduce the net efficiency slightly.

For the two cases examined here, the following observations can be made.

In case of WKE, it was more attractive and least cost option to install natural gas fired burners to the existing boiler that provided alternate fuel. The cleaner natural gas offered flexibility in operation during NOx mitigation season from May through October, and lowered overall plant NOx and SO2, and particulate emissions on annual basis. Although, biomass cofiring also offered year round reduction in $\mathrm{NOx}, \mathrm{SO} 2$, and particulate emissions, the reductions that would have been achieved could not be documented as substantial. This is due to low level of cofiring, i.e. $5-10 \%$ of boiler heat input v/s up to $100 \%$ natural gas firing is feasible. The fuel price advantage of biomass fuel over natural gas was mitigated by procuring natural gas at low price during low demand period - the summer months - which also offered most environmental benefits during high NOx season. The other advantage that biomass gasification offered - a renewable resource with no net emissions of green house gases - would be a compelling advantage, provided there was a penalty in the form of carbon tax for utilities relying on fossil fuels.

In case of TXU, there are no plans for fuel substitution in the form of natural gas. With the size of the unit - over $500 \mathrm{MW}$, natural gas firing will be difficult to justify on cost basis. This also played against the cofiring, as heat input from biomass was insignificant, less than $1 \%$. This also negated any environmental benefits from cofiring, as it would be insignificant and cannot be quantified accurately. The other factors outlined for WKE's case were also applicable to TXU case.

In conclusion, gasification based cofiring is practical and technically feasible, but under the present economic model cannot be justified. If there are economic incentives, i.e., substantial government participation in the project, carbon tax consequences, or tax incentives for green and renewable power, utilities and 
power producers will look into gasification based cofiring with more interest in the future. If there is carbon tax for utilities burning fossil fuels for power generation then the biomass based fuel will have some appeal, and biomass cofiring can become an option for further considerations. 


\section{References \& Bibliography}

\subsection{References}

1 Gregg Herman, McLean County Extension Agent for Agriculture and Natural Resources, Kentucky Department of Agriculture, McLean County, Private Communication.

2 Source: 1997 Census of Agriculture Volume 1 Geographic Area, U.S. Department of Agriculture, National Agricultural Statistics Service, http://www.nass.usda.gov/census/

3 Greenhouse Gases, Manchester Metropolitan University, Department of Atmospheric and Climate web page www.doc.mmu.ac.uk/aric/eae/Global_Warming/ Greenhouse_Gases.

4 CETCON, INC. "Summary of Results: Test No. C1", September 15, 1997 at Primenergy Test Facility, Tulsa, OK. The complete report can be obtained from Primenergy, Inc., Attn. Bill Scott, 3172 N. Toledo Ave, Tulsa, OK 74115. Phone: 918835-1011.

5 Riley Stocker Boiler Specification Sheet - by BBPower, Worcester, MA.

6 Babcock Borsig Power, Inc. Preliminary Engineering Study for Feasibility of Modular Bio-Gasifier Hot Producer Gas Injection into Pulverized Coal Fired Flat Wall Furnace at WKE Reid Plant. BBP Contract No. 200756 - May 31, 2001. Forwarded to NETL June $1,2001$. 


\section{List of Acronyms and Abbreviations}

$\begin{array}{ll}{ }^{\circ} \mathrm{C} & \text { Degrees Celsius } \\ \mathrm{Btu} & \text { British thermal unit } \\ \mathrm{CO}_{2} & \text { Carbon Dioxide } \\ \mathrm{COE} & \text { Cost of Electricity } \\ \text { deg F }{ }^{\circ} \mathrm{F} & \text { Degrees Fahrenheit } \\ \text { gr/dscf } & \text { grains per dry standard cubic feet } \\ \mathrm{HRSG} & \text { Heat Recovery Boiler } \\ \mathrm{LLC} & \text { Limited Liability Company } \\ \mathrm{MWe} & \text { Mega Watt Electrical } \\ \mathrm{NOx} & \text { Compounds of Nitrous Oxides } \\ \mathrm{O \& M} & \text { Operation and Maintenance } \\ \mathrm{P \& K} & \text { Phosphorus and Potassium based fertilizer } \\ \mathrm{PC} & \text { Pulverized Coal } \\ \text { ppbv(d) } & \text { parts per billion on volume basis (dry basis) } \\ \text { ppmv(d) } & \text { parts per million on volume basis (dry basis) } \\ \text { psi } & \text { pounds per sq. inch } \\ \text { Scf } & \text { Standard cubic feet } \\ \mathrm{SO}{ }_{2} & \text { Sulfur Dioxide } \\ \text { SOx } & \text { SO }_{2} / \mathrm{SO} \mathrm{O}_{3} \text { Oxides of sulfur } \\ \mathrm{TXU} & \text { Texas Utility Corporation } \\ \text { WKE } & \text { Western Kentucky Energy Corporation }\end{array}$




\section{Appendices}

Appendix A - WKE Case

Appendix B - TXU Case

Appendix C - BB Power Report on Boiler Penetraions 
Appendix A - WKE Case 


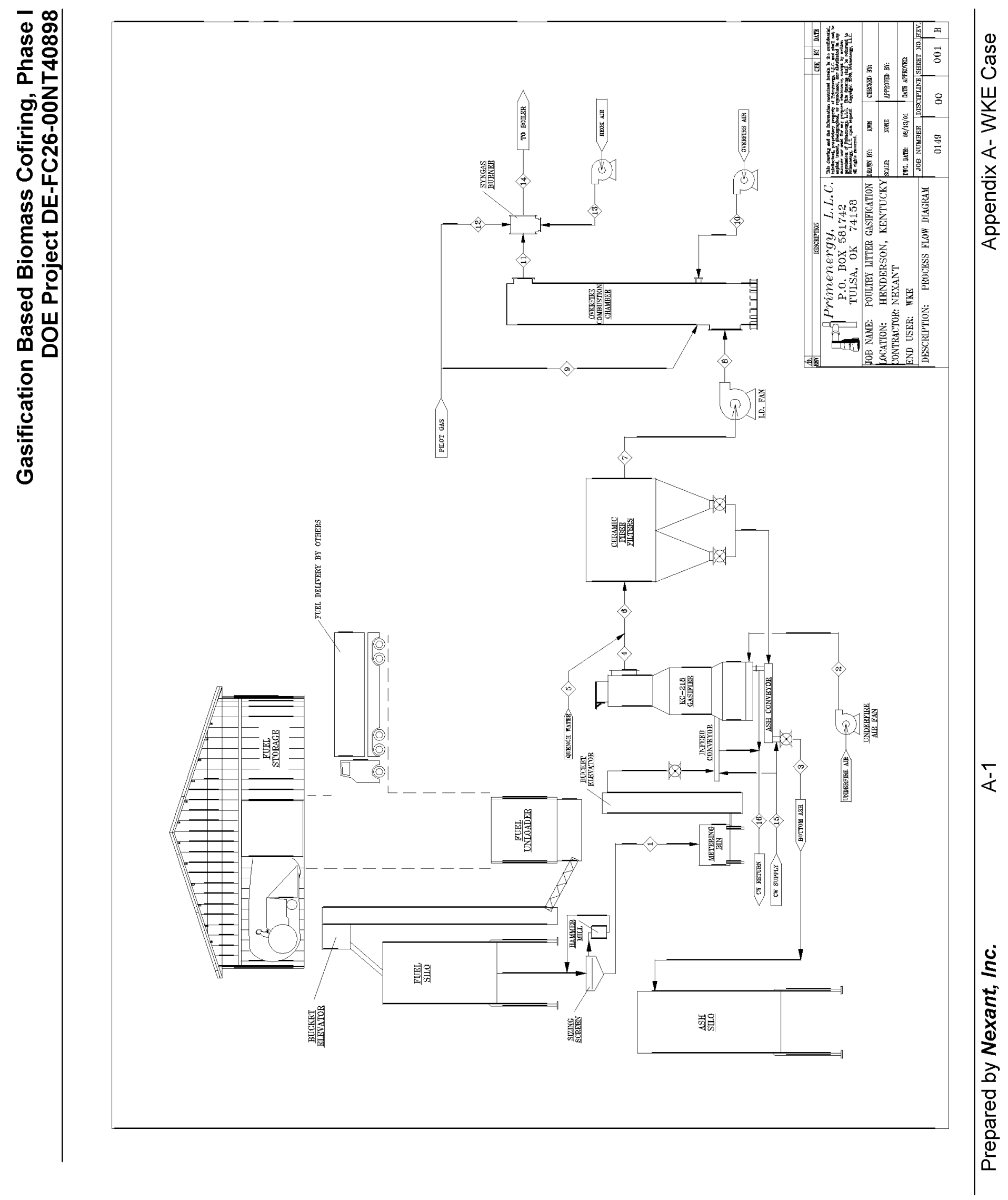




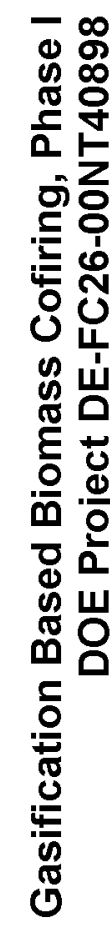

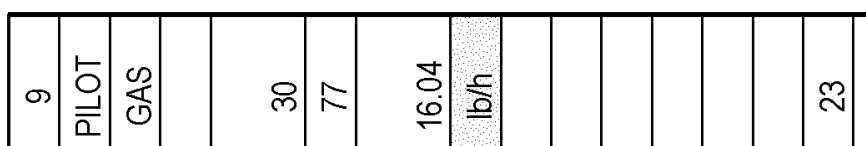

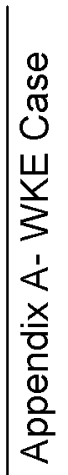

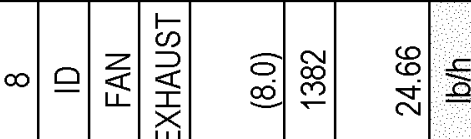

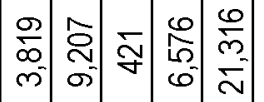

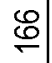

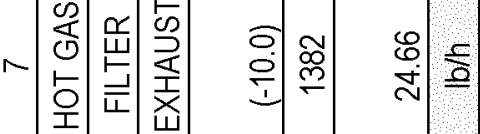

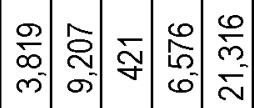

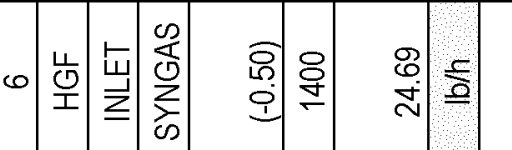

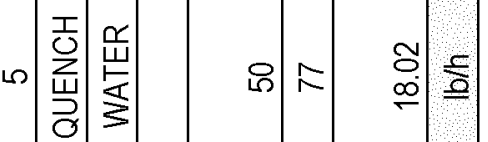

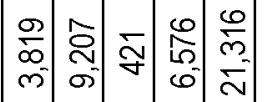
$\stackrel{8}{\circ}$ $\stackrel{\circ}{\wedge}$

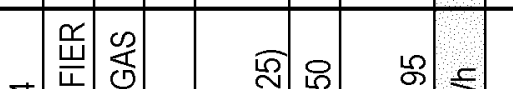

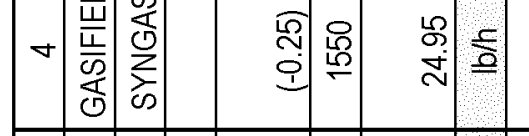

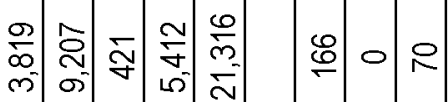
导 导

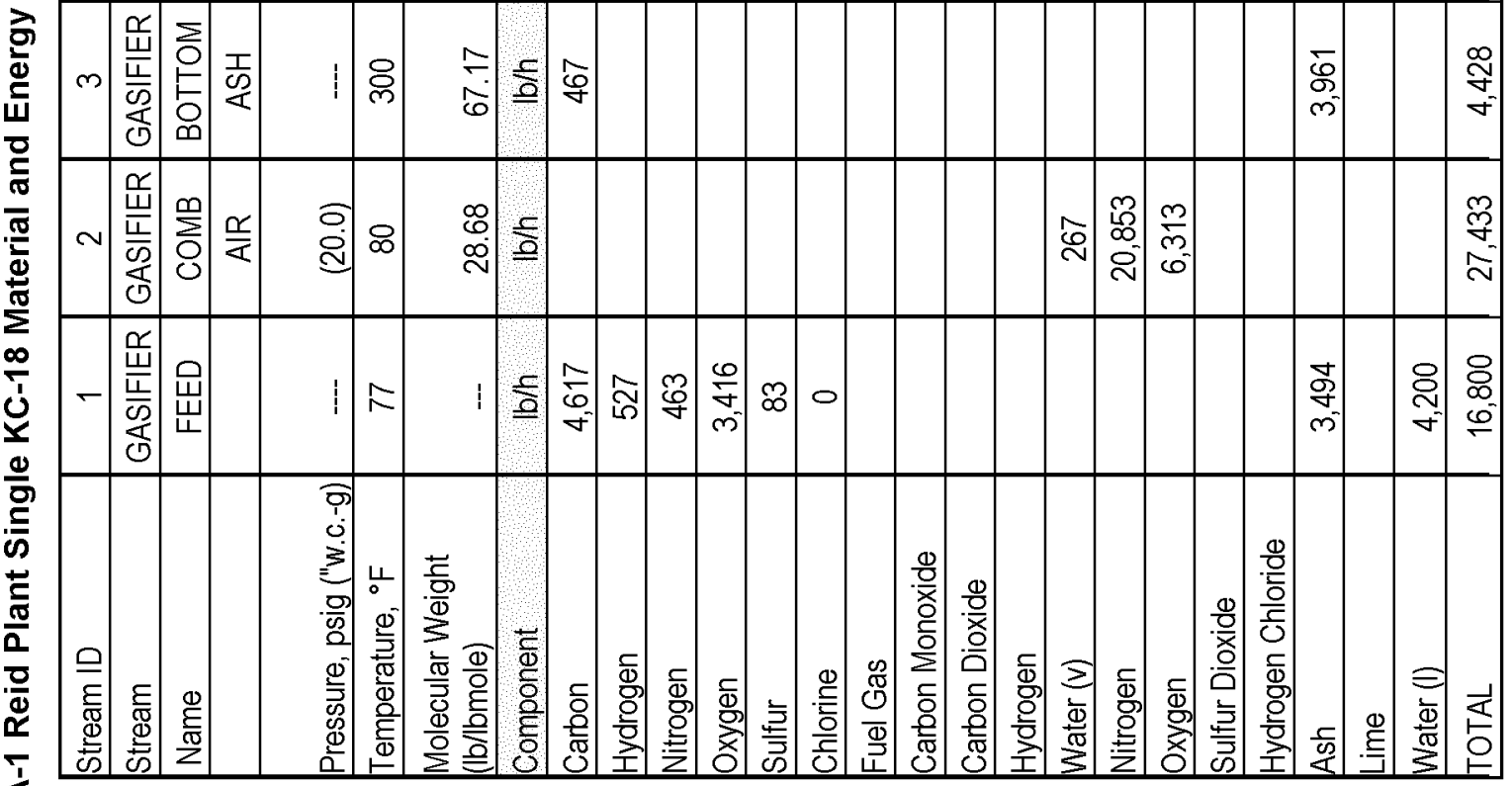

交

$\frac{0}{\circ}$ 


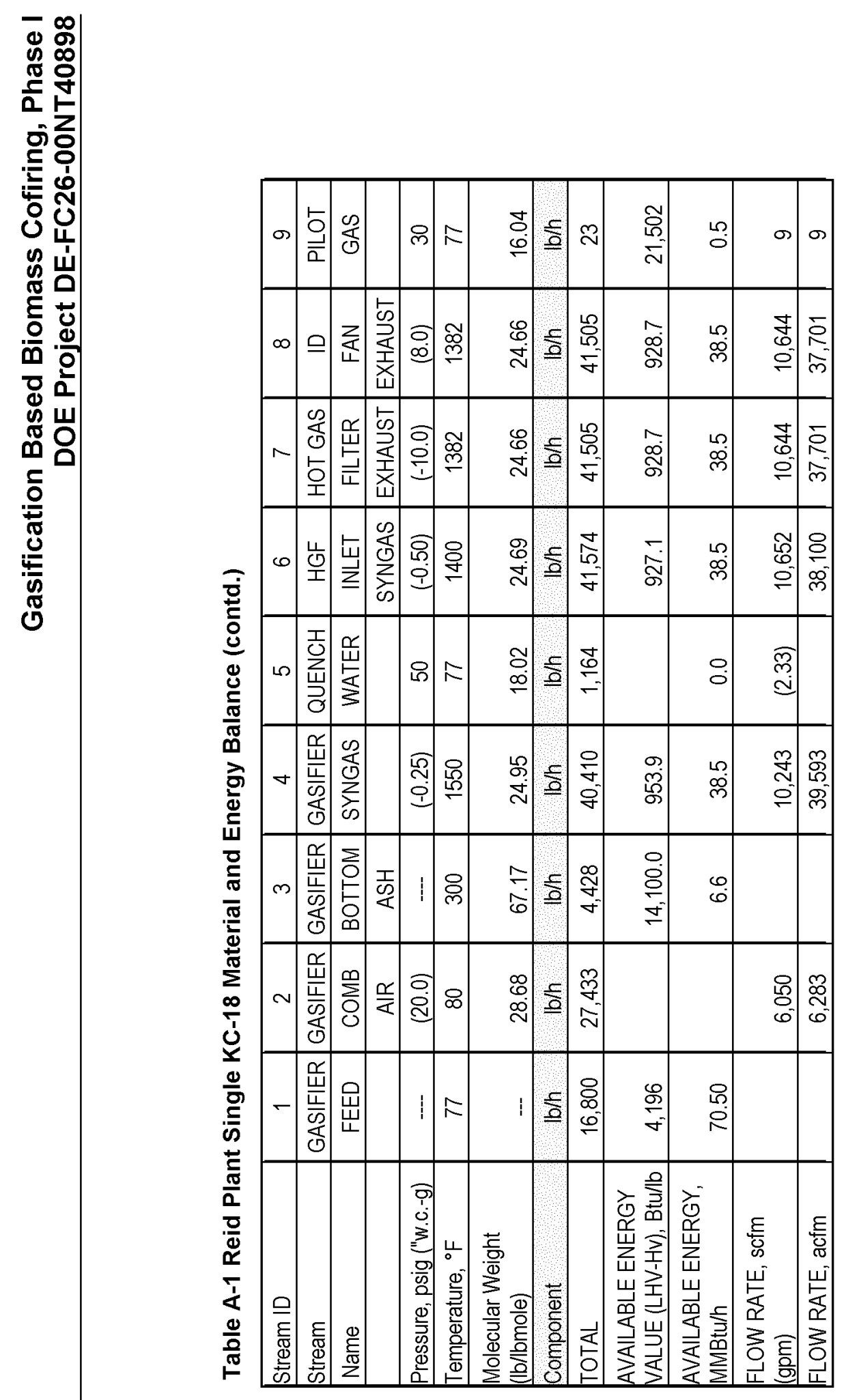

$\mid \begin{aligned} & 0 \\ & 0 \\ & 0 \\ & 0 \\ & 0 \\ & w \\ & y \\ & 3 \\ & \frac{1}{4} \\ & \frac{x}{0} \\ & \frac{1}{0} \\ & \frac{0}{0} \\ & \frac{0}{4}\end{aligned}$ 


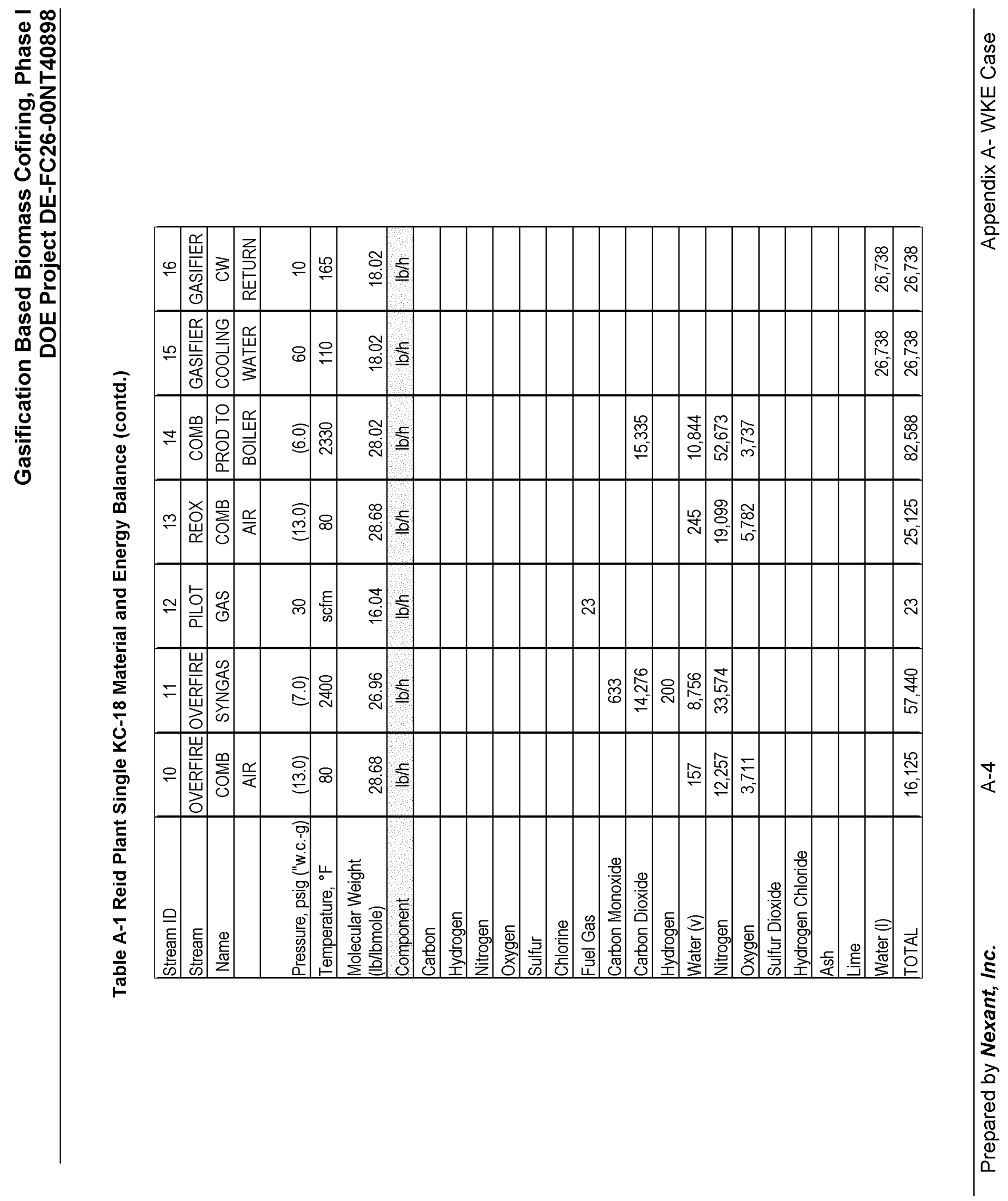



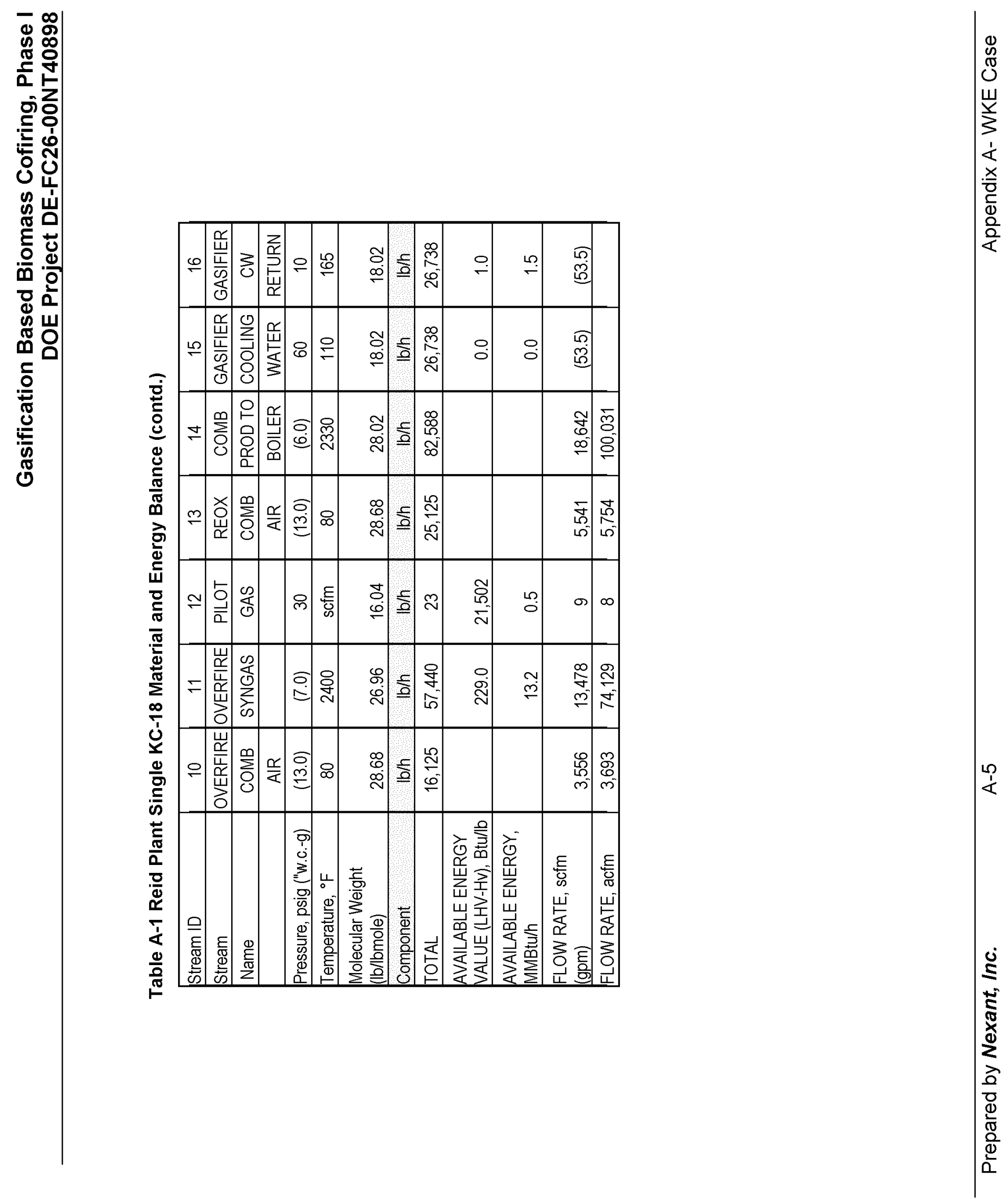


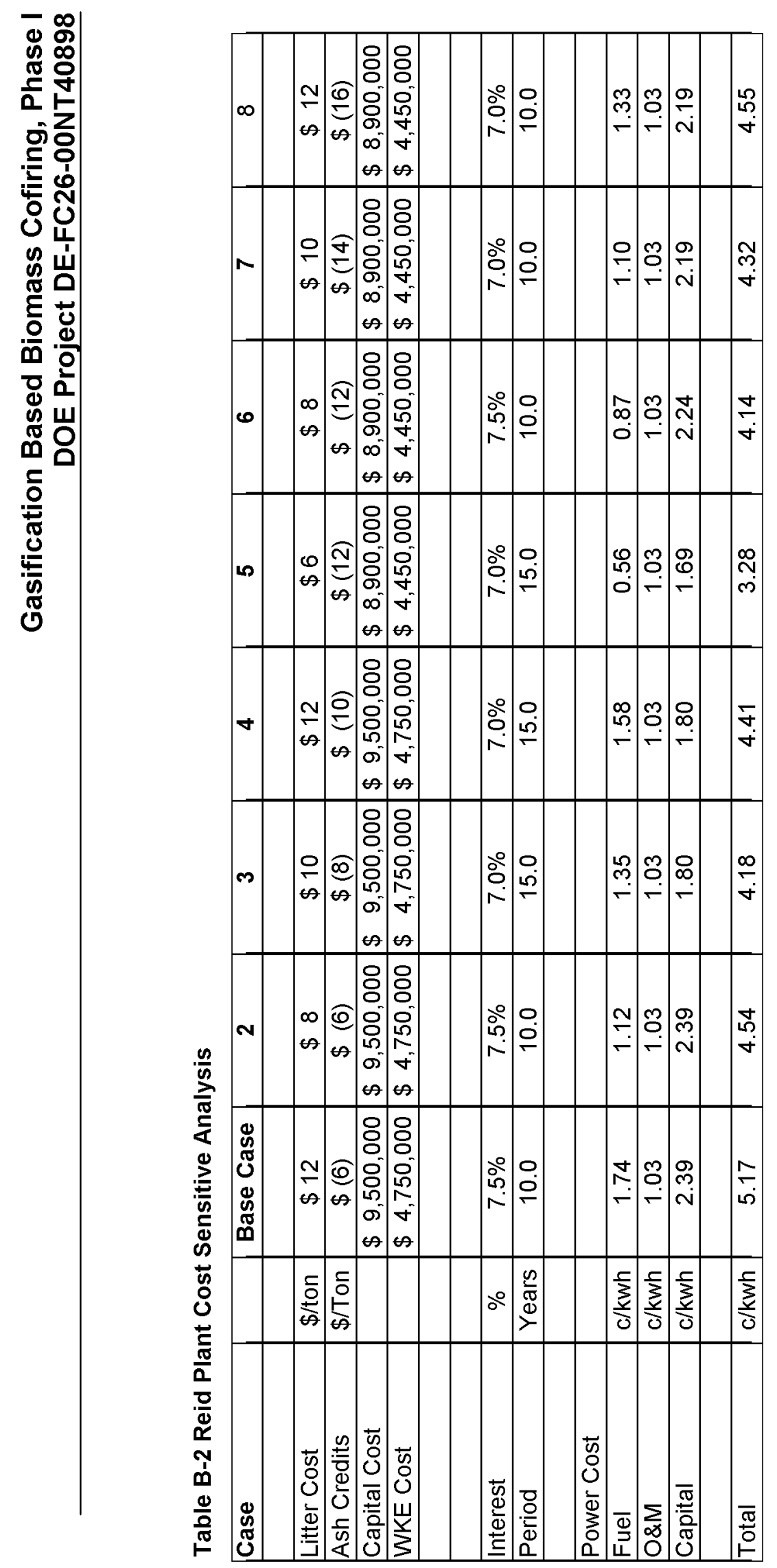

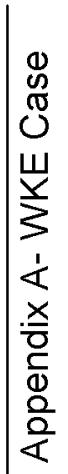


Table A-2 Electrical Power Consumption

\begin{tabular}{|c|c|c|c|c|c|}
\hline \multicolumn{6}{|c|}{ SYSTEM MOTOR LIST \& ELECTRICAL REQUIREMENT } \\
\hline ITEM & $\begin{array}{c}\text { MOTOR } \\
\text { SIZE } \\
\text { Hp }\end{array}$ & $\begin{array}{c}\text { QTY } \\
\text { SUPL. }\end{array}$ & $\begin{array}{c}\text { QTY } \\
\text { OPRTG }\end{array}$ & $\begin{array}{c}\text { OPR } \\
\text { FACTOR }\end{array}$ & $\begin{array}{c}\text { ELEC. } \\
\text { USAGE } \\
\mathrm{KW}\end{array}$ \\
\hline Fuel Receiving Hopper & 15 & 1 & 1 & 0.40 & 4.5 \\
\hline Fuel Receiving Hopper Discharge Conveyor & 15 & 1 & 1 & 0.40 & 4.5 \\
\hline Storage Silo Bucket Elevator & 20 & 1 & 1 & 0.40 & 6.0 \\
\hline Separation Screen & 5 & 1 & 1 & 0.40 & 1.5 \\
\hline Hammermill & 50 & 1 & 1 & 0.40 & 14.9 \\
\hline Hammermill Air System & 15 & 1 & 1 & 0.40 & 4.5 \\
\hline Silo Unloader & 15 & 1 & 1 & 0.40 & 4.5 \\
\hline Silo Discharge Conveyor & 10 & 1 & 1 & 0.40 & 3.0 \\
\hline Metering Bin Discharge Screw & 5 & 1 & 1 & 0.50 & 1.9 \\
\hline Bucket Elevator & 5 & 1 & 1 & 0.50 & 1.9 \\
\hline Fuel Feed Rotary Valve & 5 & 1 & 1 & 0.50 & 1.9 \\
\hline Fuel Infeed Auger & 5 & 1 & 1 & 0.50 & 1.9 \\
\hline Agitator & 5 & 1 & 1 & 0.50 & 1.9 \\
\hline Ash Discharge Auger \#1 & 3 & 1 & 1 & 0.50 & 1.1 \\
\hline Ash Discharge Auger \#2 & 3 & 1 & 1 & 0.50 & 1.1 \\
\hline Ash Cooling Auger & 5 & 1 & 1 & 0.50 & 1.9 \\
\hline Underfire Air Fan & 40 & 1 & 1 & 0.85 & 25.5 \\
\hline Cooling Water Pump & 10 & 2 & 1 & 0.38 & 2.8 \\
\hline Syngaas Compressor & 100 & 1 & 1 & 0.65 & 48.6 \\
\hline Fly Ash Discharge Valve & 1 & 2 & 2 & 0.50 & 0.7 \\
\hline Final Ash Conveyor & 10 & 1 & 1 & 0.50 & 3.7 \\
\hline ID Fan & 250 & 1 & 1 & 0.83 & 155.3 \\
\hline Overfire Air Fan & 10 & 1 & 1 & 0.50 & 3.8 \\
\hline Reox/Recycle Fan & 10 & 1 & 1 & 0.55 & 4.1 \\
\hline Air Compressor & 100 & 1 & 1 & 0.50 & 37.4 \\
\hline Miscellaneous Electrical Usage & ---- & ---- & ---- & ---- & 2.0 \\
\hline Total & 567.0 & & & & 340.6 \\
\hline
\end{tabular}




\section{Reid Plant Boiler Penetration Schematic}

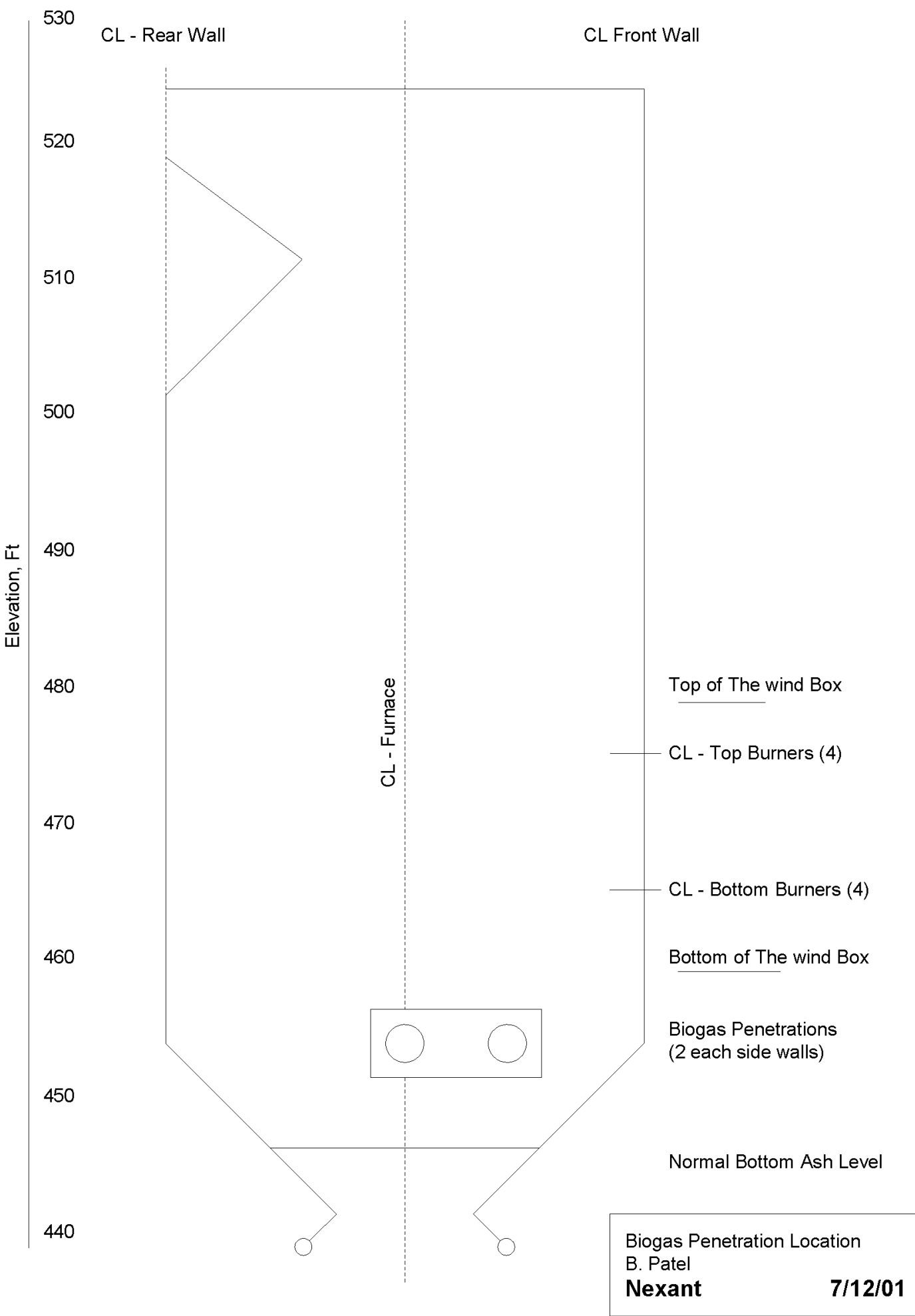


Gasification Based Biomass Cofiring, Phase I DOE Project DE-FC26-00NT40898

\section{Boiler Penetration Sizing Nomogram}

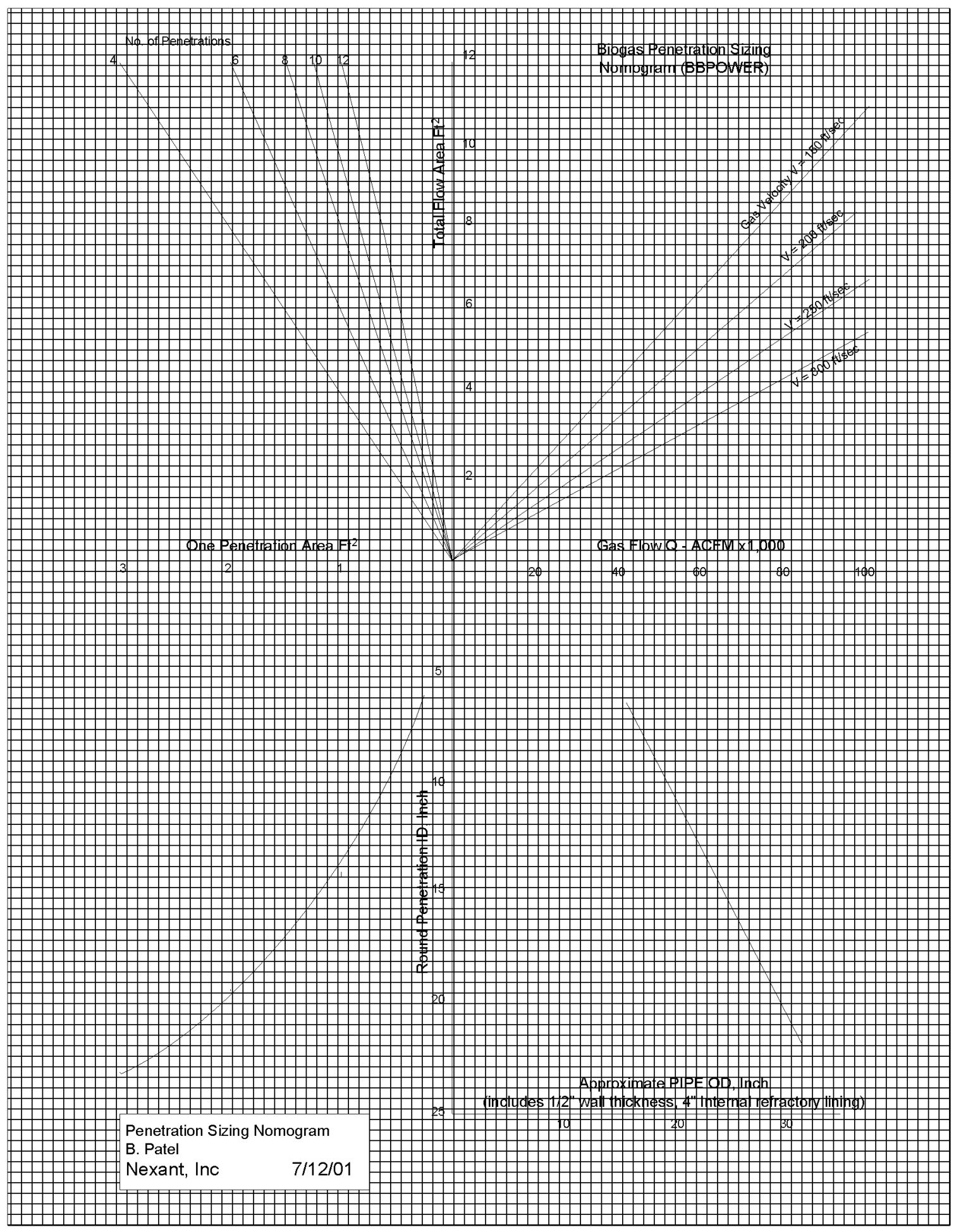




\section{Proposed Gasifier Location at Reid Plant}

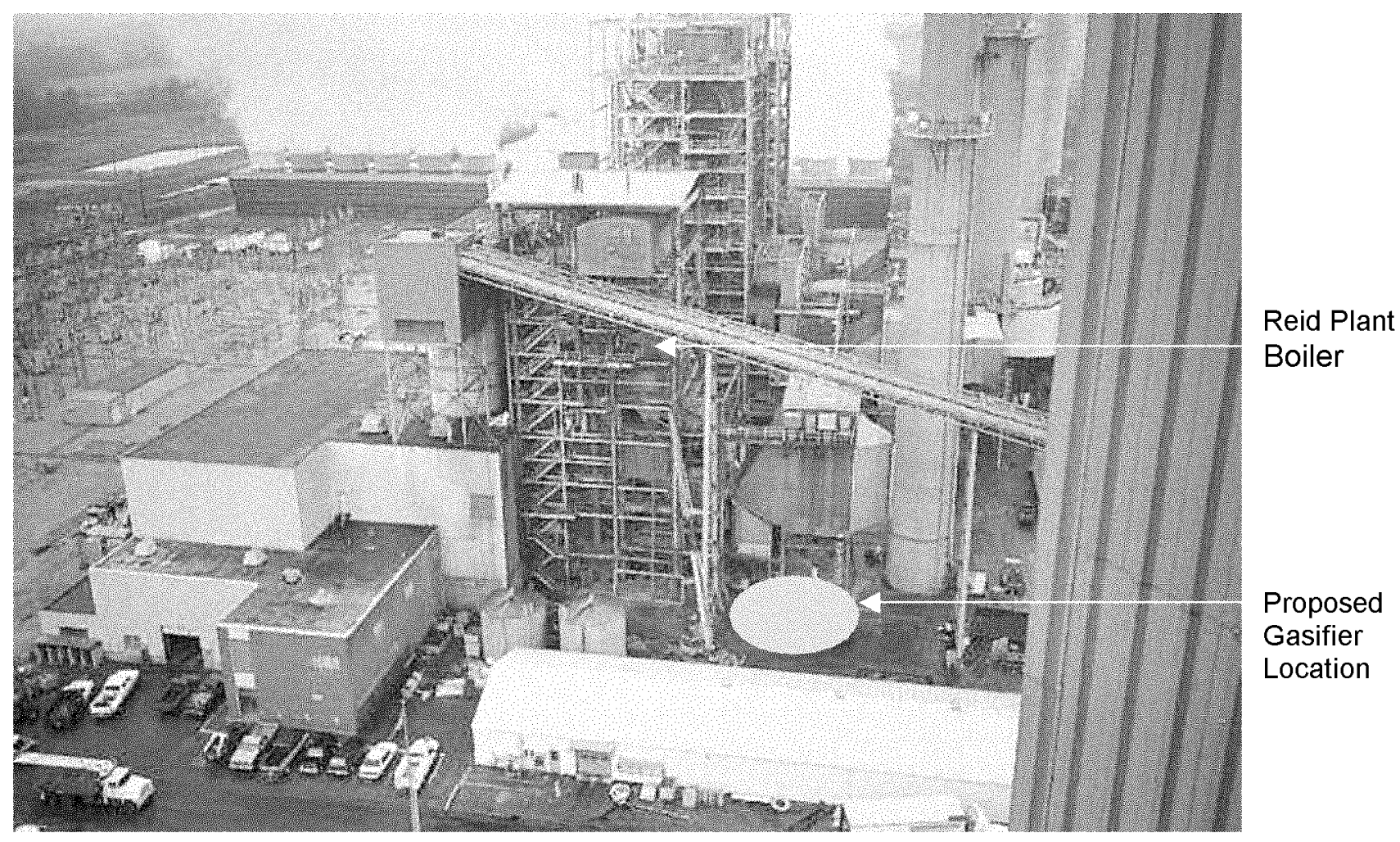




\section{Fuel Receiving and Storage}

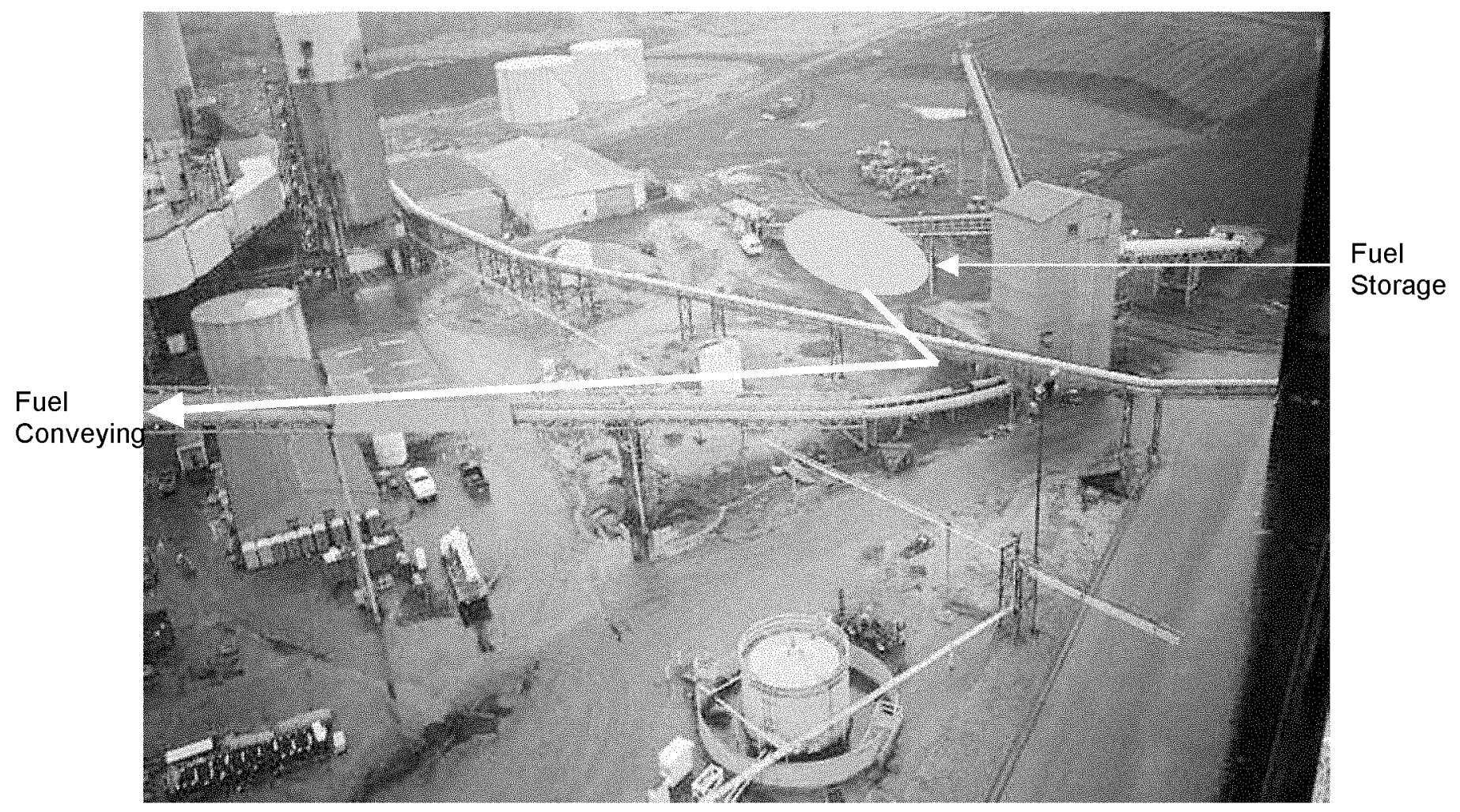




\section{Reid Plant Boiler Penetrations}

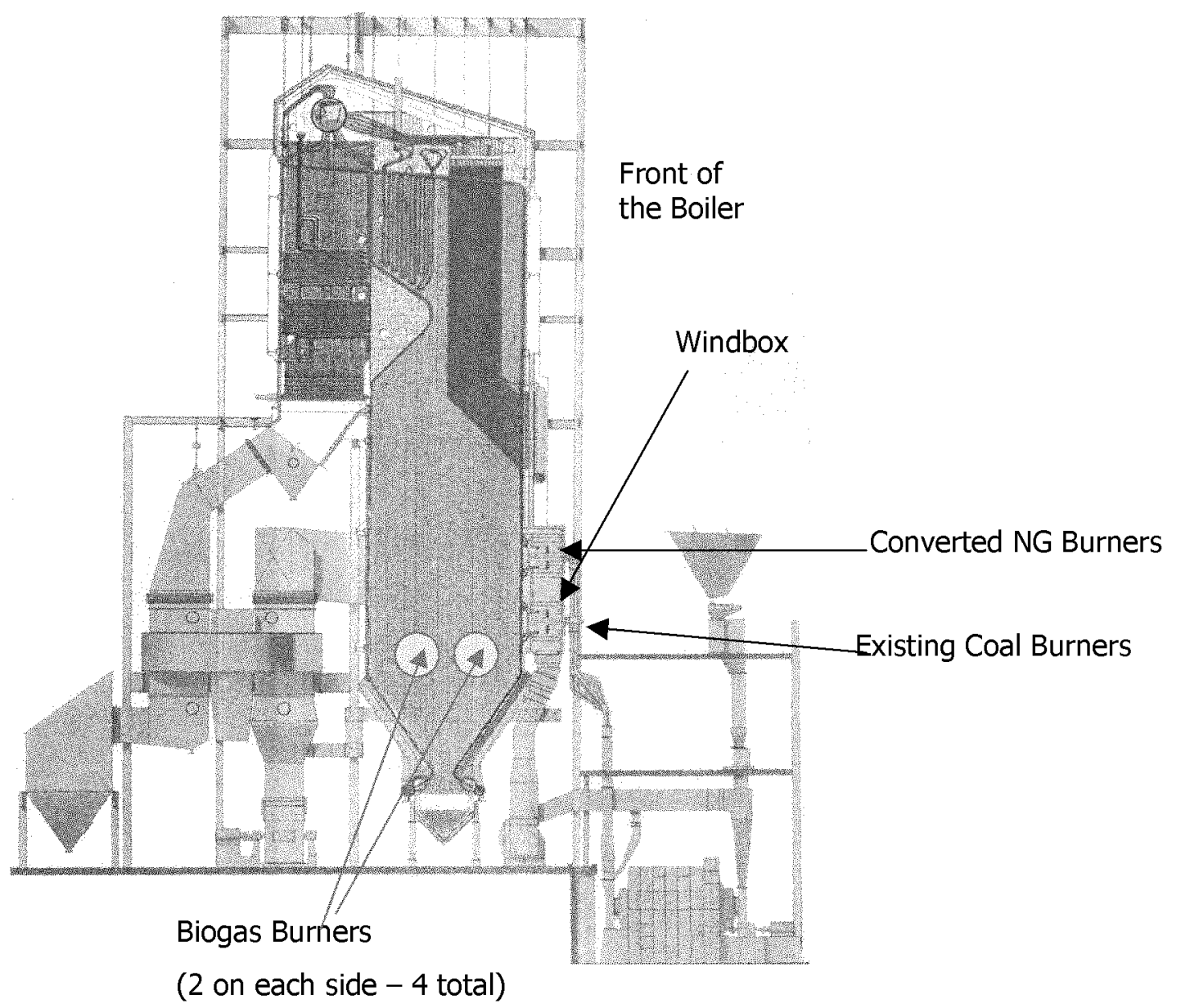

- Four Penetrations

- 2 on each side of the boiler

- Just below the lower windbox line

- Pressure at the burner -10"-12" of WC

- Velocity at the burner $150 \sim 300 \mathrm{ft} / \mathrm{sec}$

- Flow 70,000 100,000 scfm 


\section{Reid Plant Turbine Energy Balance}

Turbine Name Plate Data by GE

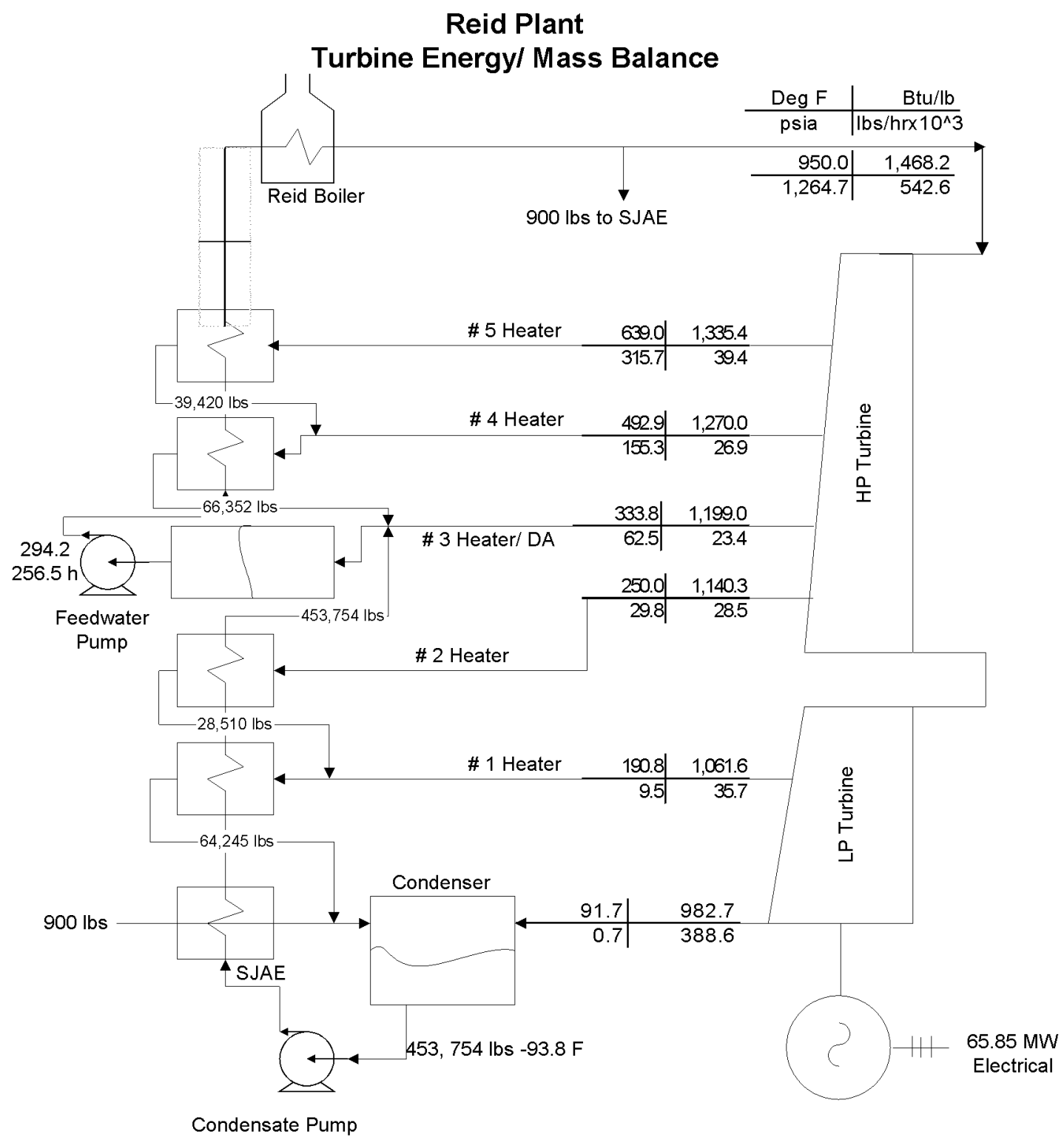

Ref: GE Design Case @ 65.85 MW Gross Turbine Output 


\section{Turbine Design Point steam Load v/s Boiler heat Input}

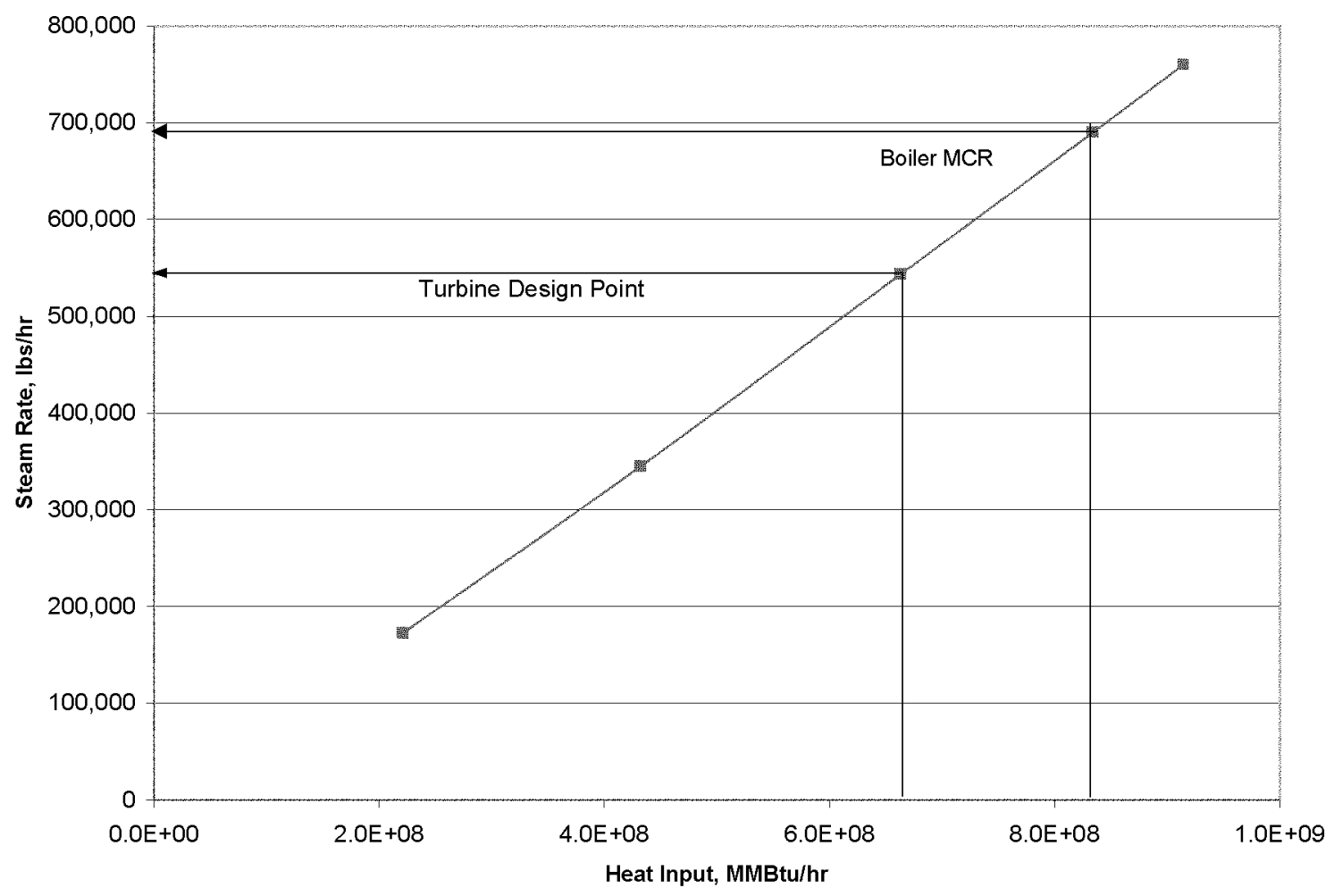


Appendix B - TXU Case 


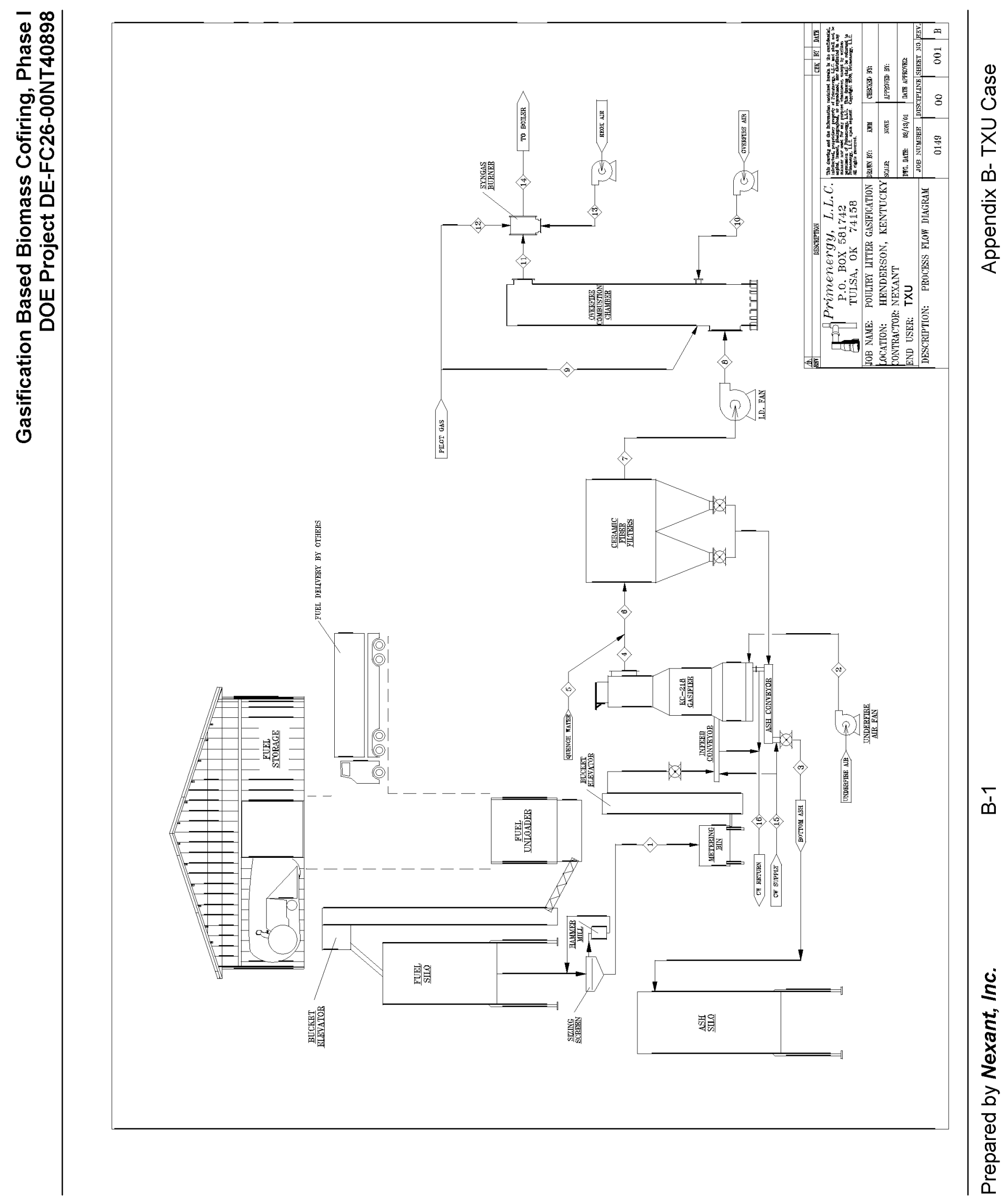




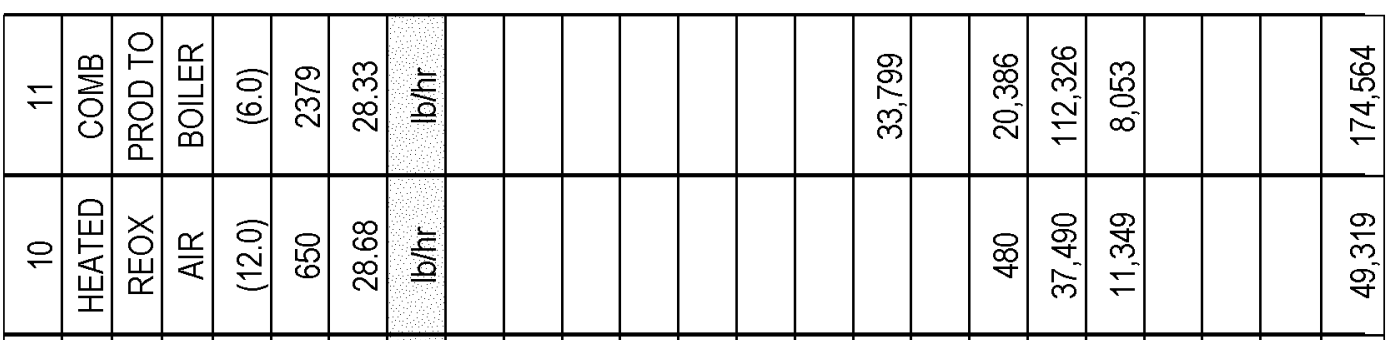

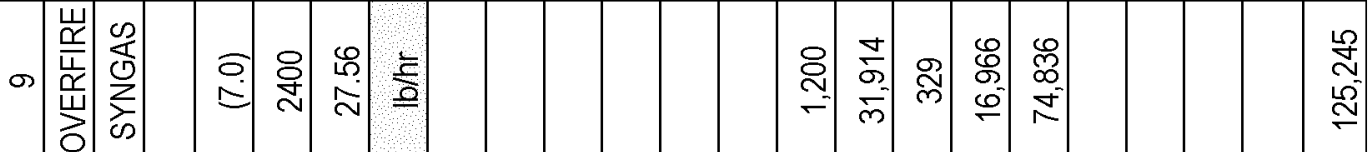

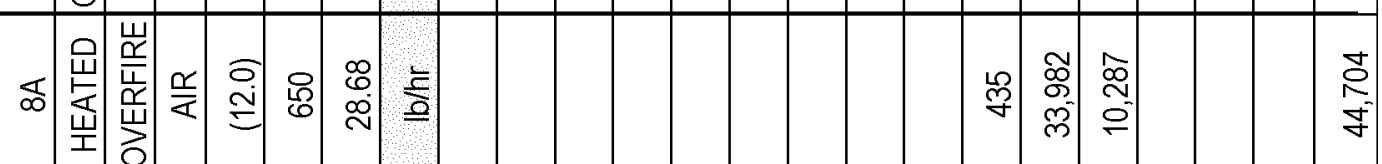

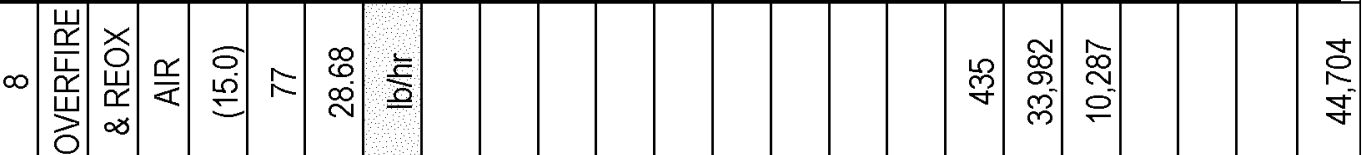

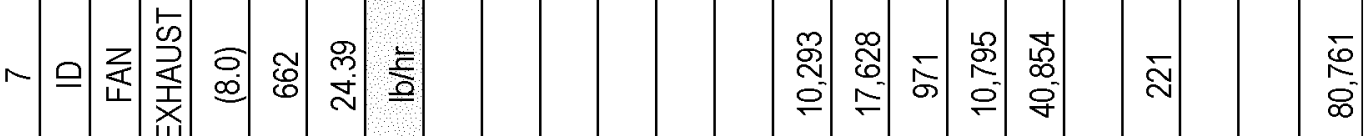

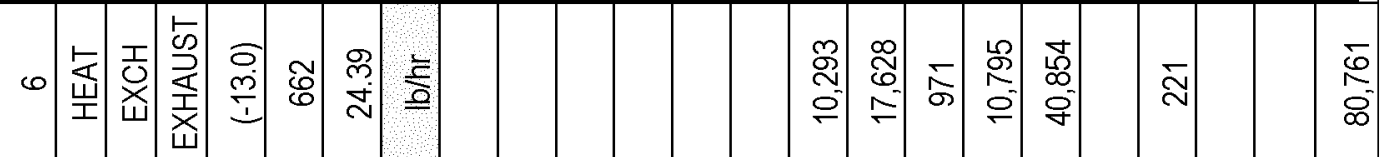

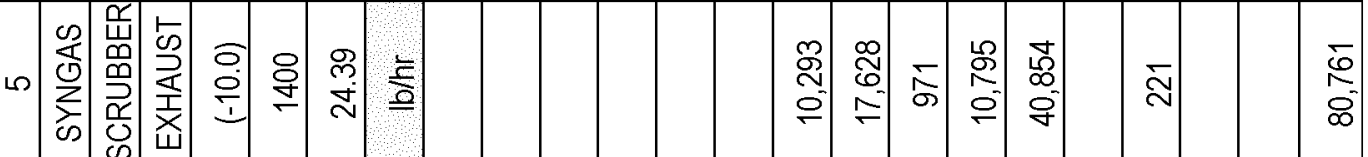

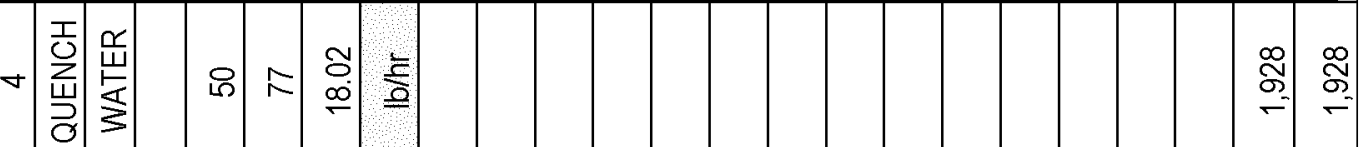

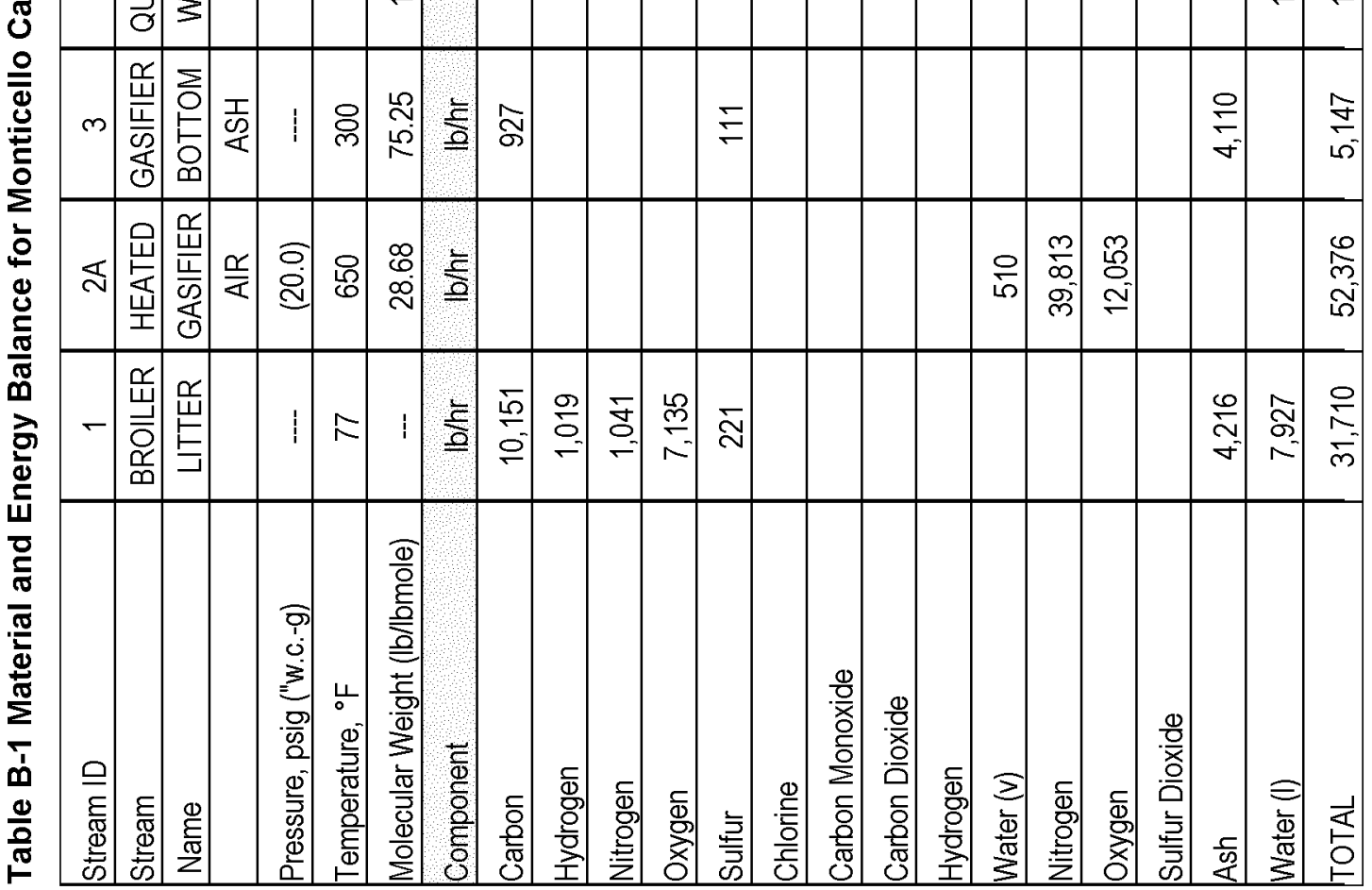

ஸ́ 


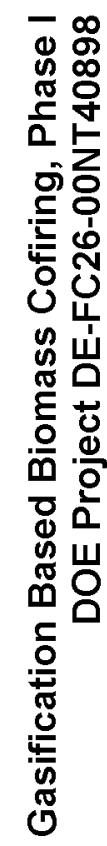

\begin{tabular}{|c|c|c|c|c|c|c|c|c|c|c|c|c|c|}
\hline$\mp$ & 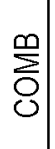 & 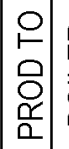 & 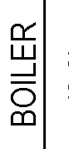 & $\begin{array}{l}0 \\
0 \\
0\end{array}$ & $\begin{array}{l}\stackrel{\Omega}{2} \\
\stackrel{v}{v}\end{array}$ & $\begin{array}{l}\stackrel{m}{m} \\
\stackrel{\infty}{\sim}\end{array}$ & 흘 & 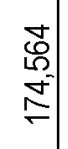 & & & 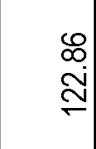 & \begin{tabular}{|l|}
0 \\
0 \\
0 \\
0 \\
0 \\
$m$
\end{tabular} \mid & $\begin{array}{c}0 \\
\stackrel{Q}{\sim} \\
\stackrel{\sim}{\sim} \\
\stackrel{\sim}{\sim}\end{array}$ \\
\hline 으 & 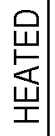 & 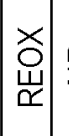 & $\frac{\alpha}{\bar{\alpha}}$ & $\begin{array}{l}\vec{O} \\
\stackrel{\Xi}{=}\end{array}$ & 용 & $\begin{array}{l}\infty \\
@ \\
\infty \\
\sim\end{array}$ & 흥 & $\begin{array}{c}\frac{\sigma}{m} \\
\frac{\sigma}{\sigma}\end{array}$ & & & o & $\mid \begin{array}{c}\hat{\widehat{o}} \\
\mathbf{\infty} \\
0 \\
\end{array}$ & 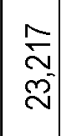 \\
\hline () & 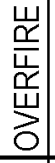 & 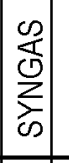 & & $\begin{array}{l}0 \\
0\end{array}$ & $\stackrel{8}{\stackrel{9}{\sim}}$ & $\begin{array}{l}\stackrel{0}{0} \\
\stackrel{\sim}{\sim}\end{array}$ & 릉 & 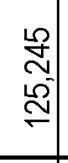 & $\stackrel{\infty}{=}$ & $\stackrel{\widetilde{N}}{\sim}$ & $\begin{array}{l}\text { f. } \\
\dot{8}\end{array}$ & 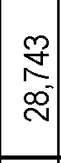 & $\mid$\begin{tabular}{l}
1 \\
0 \\
$\infty$ \\
0 \\
\hdashline
\end{tabular} \\
\hline$\underset{\infty}{\varpi}$ & $\begin{array}{l}\text { 崖 } \\
\text { 岌 }\end{array}$ & 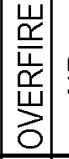 & $\frac{\alpha}{\approx}$ & 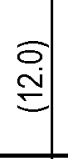 & $\begin{array}{l}0 \\
6 \\
0\end{array}$ & $\begin{array}{l}\infty \\
\infty \\
\infty \\
\sim\end{array}$ & $\frac{\bar{s}}{\rho}$ & $\begin{array}{l}\vec{D} \\
\dot{f}\end{array}$ & & & $\begin{array}{c}\hat{m} \\
0\end{array}$ & \begin{tabular}{|c|}
$\mathscr{8}$ \\
$\infty$ \\
$\infty$ \\
$\sigma$
\end{tabular} & 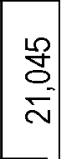 \\
\hline$\infty$ & 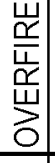 & 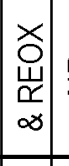 & $\frac{\alpha}{\bar{\tau}}$ & $\begin{array}{l}\text { 움 } \\
\stackrel{\leftrightarrow}{=}\end{array}$ & 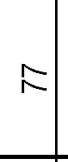 & $\begin{array}{c}\infty \\
⿱ \\
\infty \\
\sim\end{array}$ & 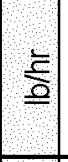 & $\begin{array}{l}\vec{D} \\
\dot{f} \\
\dot{f}\end{array}$ & & & & $\begin{array}{l}\text { \% } \\
\text { o. } \\
\text { on }\end{array}$ & $\stackrel{\infty}{\stackrel{\infty}{\circ}}$ \\
\hline$N$ & 으 & $\underset{\square}{z}$ & 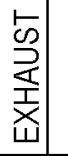 & $\begin{array}{l}0 \\
00 \\
0\end{array}$ & $\mathbb{~}$ & $\begin{array}{l}\stackrel{8}{m} \\
\stackrel{\sim}{\sim}\end{array}$ & 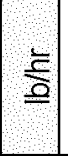 & $\begin{array}{l}\overline{0} \\
\bar{\infty} \\
\end{array}$ & $\stackrel{\bar{\infty}}{\check{-}}$ & 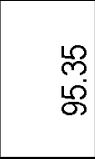 & $\begin{array}{l}8 \\
\stackrel{5}{+}\end{array}$ & 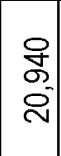 & $\frac{8}{\frac{8}{8}}$ \\
\hline 6 & 富 & 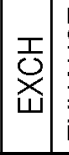 & 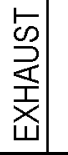 & $\begin{array}{l}\sigma \\
\dot{m} \\
\stackrel{\Xi}{I}\end{array}$ & $\mathbb{\widetilde { Z }}$ & $\begin{array}{l}\stackrel{8}{m} \\
\stackrel{i}{v}\end{array}$ & 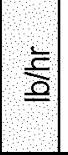 & $\begin{array}{l}\overline{0} \\
\infty \\
\infty\end{array}$ & $\stackrel{\bar{\infty}}{\check{-}}$ & 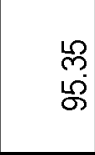 & $\begin{array}{l}8 \\
\stackrel{9}{+}\end{array}$ & $\mid \begin{array}{l}9 \\
6 \\
0 \\
0\end{array}$ & $\frac{8}{\frac{8}{\sigma^{\circ}}}$ \\
\hline 10 & $\sum_{\infty}^{\infty}$ & 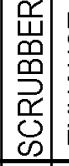 & 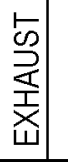 & $\begin{array}{l}0 \\
0 \\
\stackrel{0}{ \pm}\end{array}$ & 多 & $\begin{array}{l}\stackrel{m}{0} \\
\stackrel{\sim}{\sim}\end{array}$ & 흥 & $\begin{array}{l}\overline{0} \\
\overline{0} \\
\bar{\infty}\end{array}$ & $\stackrel{\bar{\infty}}{\check{-}}$ & $\begin{array}{l}\stackrel{1}{m} \\
\stackrel{m}{\Omega}\end{array}$ & 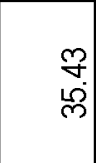 & $\mid \begin{array}{l}\text { O } \\
6 \\
0 \\
0\end{array}$ & $\begin{array}{l}\mathscr{D} \\
\infty \\
\mathbb{N}\end{array}$ \\
\hline$\nabla$ & $\begin{array}{l}\frac{T}{\mathrm{U}} \\
\stackrel{\mathrm{Z}}{\mathrm{U}} \\
\stackrel{\mathrm{O}}{\mathrm{O}}\end{array}$ & 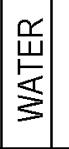 & & 8 & $\curvearrowright$ & 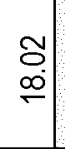 & $\stackrel{\underline{\underline{\partial}}}{\underline{\underline{\underline{\theta}}}}$ & 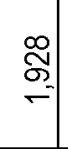 & & & & \begin{tabular}{|l|}
0 \\
0 \\
0
\end{tabular} & \\
\hline$m$ & 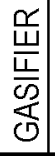 & 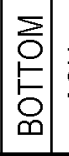 & $\frac{T}{\infty}$ & 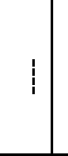 & ঃ్లి & $\begin{array}{l}\stackrel{2}{N} \\
\stackrel{N}{N}\end{array}$ & $\stackrel{\underline{\underline{\partial}}}{\underline{\underline{\rho}}}$ & $\underset{50}{f}$ & & $\begin{array}{l}\mathscr{8} \\
\dot{m}\end{array}$ & & & \\
\hline$\underset{\sim}{\mathbb{N}}$ & $\begin{array}{l}\stackrel{0}{\uplus} \\
\underset{⿱ ㇒}{\Psi} \\
\end{array}$ & 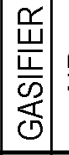 & $\frac{\alpha}{\alpha}$ & $\begin{array}{l}0 \\
0 \\
0\end{array}$ & 융 & $\begin{array}{l}\infty \\
0 \\
\infty \\
\infty\end{array}$ & $\frac{}{\underline{\rho}}$ & $\begin{array}{c}\infty \\
\tilde{m} \\
\widetilde{N} \\
\tilde{N}\end{array}$ & & & 守 & 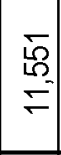 & 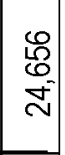 \\
\hline- & 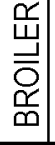 & 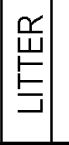 & & 1 & 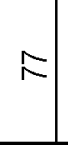 & 1 & 흐 & $\begin{array}{l}\text { 음 } \\
\bar{m} \\
\bar{m}\end{array}$ & 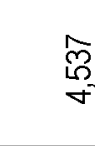 & $\begin{array}{l}\stackrel{\infty}{\infty} \\
\stackrel{\sim}{\sim}\end{array}$ & & & \\
\hline 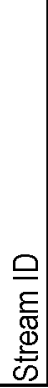 & $\begin{array}{l}E \\
\mathbb{D} \\
\stackrel{\mathbb{D}}{D} \\
\omega\end{array}$ & 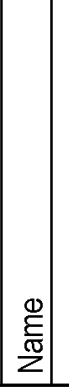 & & 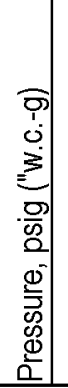 & 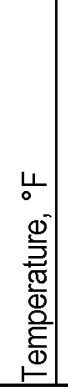 & 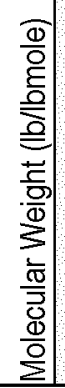 & $\begin{array}{l}\bar{c} \\
\bar{\Phi} \\
\bar{\delta} \\
\bar{\delta} \\
\bar{\delta} \\
\mathcal{O}\end{array}$ & $\begin{array}{l}\frac{1}{\mathbb{5}} \\
\mathrm{O} \\
\mathrm{V}\end{array}$ & 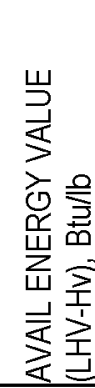 & 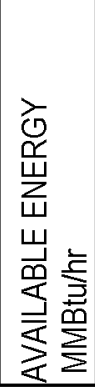 & 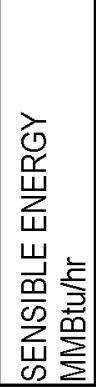 & 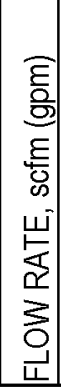 & 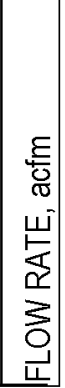 \\
\hline
\end{tabular}

m 
Table B-2 Electrical Usage for Monticello Case

\begin{tabular}{|c|c|c|c|c|c|}
\hline \multicolumn{6}{|c|}{ SYSTEM MOTOR LIST \& ELECTRICAL REQUIREMENT } \\
\hline ITEM & $\begin{array}{c}\text { MOTOR } \\
\text { SIZE } \\
\mathrm{Hp}\end{array}$ & $\begin{array}{c}\text { QTY } \\
\text { SUPLD }\end{array}$ & $\begin{array}{c}\text { QTY } \\
\text { OPRTG }\end{array}$ & $\begin{array}{c}\text { OPRTG } \\
\text { FACTOR }\end{array}$ & $\begin{array}{c}\text { ELCTL } \\
\text { USAGE } \\
\mathrm{KW}\end{array}$ \\
\hline Fuel Receiving Hopper & 15 & 1 & 1 & 0.40 & 4.5 \\
\hline Fuel Receiving Hopper Discharge Conveyor & 15 & 1 & 1 & 0.40 & 4.5 \\
\hline Storage Silo Bucket Elevator & 20 & 1 & 1 & 0.40 & 6.0 \\
\hline Separation Screen & 5 & 1 & 1 & 0.40 & 1.5 \\
\hline Hammer mill & 50 & 1 & 1 & 0.40 & 14.9 \\
\hline Hammer mill Air System & 15 & 1 & 1 & 0.40 & 4.5 \\
\hline Silo Unloader & 15 & 2 & 2 & 0.40 & 9.0 \\
\hline Silo Discharge Conveyor & 10 & 2 & 2 & 0.40 & 6.0 \\
\hline Metering Bin Discharge Screw & 5 & 2 & 2 & 0.50 & 3.7 \\
\hline Bucket Elevator & 5 & 2 & 2 & 0.50 & 3.7 \\
\hline Fuel Feed Rotary Valve & 5 & 2 & 2 & 0.50 & 3.7 \\
\hline Fuel Infeed Auger & 5 & 2 & 2 & 0.50 & 3.7 \\
\hline Agitator & 5 & 2 & 2 & 0.50 & 3.7 \\
\hline Ash Cooling Auger & 5 & 2 & 2 & 0.50 & 3.7 \\
\hline Underfire Air Fan & 50 & 2 & 2 & 0.79 & 58.9 \\
\hline Cooling Water Pump & 15 & 2 & 1 & 0.70 & 7.9 \\
\hline Syngaas Compressor & 150 & 1 & 1 & 0.75 & 84.0 \\
\hline Fly Ash Discharge Valve & 1 & 4 & 4 & 0.50 & 1.5 \\
\hline Final Ash Conveyor & 10 & 1 & 1 & 0.50 & 3.7 \\
\hline Ash Bucket Elevator & 10 & 1 & 1 & 0.50 & 3.7 \\
\hline ID Fan & 250 & 2 & 2 & 0.69 & 256.1 \\
\hline Reox / Overfire Air Fan & 60 & 2 & 2 & 0.73 & 65.6 \\
\hline Air Compressor & 25 & 1 & 1 & 0.75 & 14.0 \\
\hline Miscellaneous Electrical Usage & --- & ---- & --- & --- & 5.0 \\
\hline Total & & & & & 573.7 \\
\hline
\end{tabular}


Table B-2 Texas Lignite Analysis (Monticello Boiler Fuel)

\begin{tabular}{|l|c|l|}
\hline \multicolumn{1}{|c|}{ Texas Lignite } & Value & \multicolumn{1}{c|}{ Units } \\
\hline Fuel HHV & $15738(6,767)$ & $\mathrm{kJ} / \mathrm{kg}(\mathrm{Btu} / \mathrm{lb})$ \\
\hline $\mathrm{C}$ & 39.20 & $\%$ \\
\hline $\mathrm{H}$ & 2.99 & \\
\hline $\mathrm{O}$ & 11.04 & \\
\hline $\mathrm{N}$ & 0.58 & \\
\hline $\mathrm{S}$ & 0.61 & \\
\hline Ash & 14.31 & \\
\hline Moisture & 31.27 & \\
\hline Total & 100.00 & \\
\hline
\end{tabular}

Table B-3 Monticello Boiler Design Data

\begin{tabular}{|c|c|c|c|}
\hline Monticello Unit $1 \& 2$ & Units & Control Point & MCR \\
\hline Fuel & & Texas Lignite & Texas Lignite \\
\hline Evaporation & Ibs/h & $3,200,000$ & $4,025,000$ \\
\hline FW Temp & $\mathrm{F}$ & 478 & 501 \\
\hline FW Pressure (calc) & psig & 3,750 & 4,068 \\
\hline SH Outlet Temp & $\mathrm{F}$ & 1,005 & 1,005 \\
\hline SH Outlet Press & psig & 3,595 & 3,825 \\
\hline SH Pressure Drop & psig & 141 & 222 \\
\hline Reheat Flow & Ibs/h & $2,814,000$ & $3,520,000$ \\
\hline Reheat inlet Temp & $\mathrm{F}$ & 550 & 572 \\
\hline Reheat Inlet Press & psig & 542 & 682 \\
\hline Reheat Outlet Temp & $F$ & 1,005 & 1,005 \\
\hline Reheater Press Drop & psig & 28 & 35 \\
\hline Econmizer Press Drop & psi & 14 & 21 \\
\hline Gas Drop - Furnace to Econ & "wg & 2.45 & 3.65 \\
\hline Gas Drop Econ Outlet to AH Outlet & "wg & 4.80 & 6.85 \\
\hline Gas Temp Entering $\mathrm{AH}$ & $\mathrm{F}$ & 805 & 860 \\
\hline Gas Temp Leaving $\mathrm{AH}$ & $\mathrm{F}$ & 327 & 351 \\
\hline Gas Temp Leaving $\mathrm{AH}$ & $\mathrm{F}$ & 311 & 336 \\
\hline Air Temp Air Heater & $\mathrm{F}$ & 85 & 85 \\
\hline Air Temp Leaving & $\mathrm{F}$ & 701 & 730 \\
\hline Air Press Air Heater & "wg & 7.90 & 10.35 \\
\hline Amb. Air Temp & $\mathrm{F}$ & 80 & 80 \\
\hline Excess Air Econ & $\%$ & 20 & 20 \\
\hline Fuel Fired & $\mathrm{lbs} / \mathrm{h}$ & 681,000 & 836,000 \\
\hline Efficiency & $\%$ & 82.69 & 82.06 \\
\hline
\end{tabular}


Table B-4 Monticello Plant Sensitivity Case

\begin{tabular}{|c|c|c|c|c|c|c|c|c|c|c|}
\hline & & & & & & & & \\
\hline Case & $\begin{array}{c}\text { Litter } \\
\text { Cost }\end{array}$ & $\begin{array}{c}\text { Ash } \\
\text { Credits }\end{array}$ & Capital Cost & $\begin{array}{c}\text { TXU Cost } \\
\text { Share }\end{array}$ & Interest & Period & Fuel & O\&M & Capital & Total \\
\hline & $\$$ /ton & $\$ /$ Ton & & & $\%$ & Years & c/kWh & c/kwh & c/kwh & c/kwh \\
\hline $\begin{array}{c}\text { Base } \\
\text { Case }\end{array}$ & 8 & 0 & $\$ 14,882,622$ & $\$ 14,882,622$ & $7.5 \%$ & 10 & 1.00 & 0.78 & 2.69 & 4.47 \\
\hline 2 & 8 & $(6)$ & $\$ 4,882,622$ & $\$ 14,882,622$ & $7.5 \%$ & 10 & 0.83 & 0.78 & 2.69 & 4.30 \\
\hline 3 & 8 & 0 & $\$ 14,882,622$ & $\$ 7,441,311$ & $7.5 \%$ & 10 & 1.00 & 0.78 & 1.34 & 3.13 \\
\hline 4 & 6 & $(6)$ & $\$ 14,882,622$ & $\$ 14,882,622$ & $7.5 \%$ & 10 & 0.58 & 0.78 & 2.69 & 4.05 \\
\hline 5 & 6 & $(6)$ & $\$ 14,882,622$ & $\$ 7,441,311$ & $7.5 \%$ & 10 & 0.58 & 0.78 & 1.34 & 2.71 \\
\hline 6 & 4 & 0 & $\$ 14,882,622$ & $\$ 14,882,622$ & $7.5 \%$ & 10 & 0.50 & 0.78 & 2.69 & 3.97 \\
\hline 7 & 4 & 0 & $\$ 14,882,622$ & $\$ 7,441,311$ & $7.5 \%$ & 10 & 0.50 & 0.78 & 1.34 & 2.63 \\
\hline 8 & 0 & $(6)$ & $\$ 14,882,622$ & $\$ 14,882,622$ & $7.5 \%$ & 10 & -0.17 & 0.78 & 2.69 & 3.30 \\
\hline
\end{tabular}




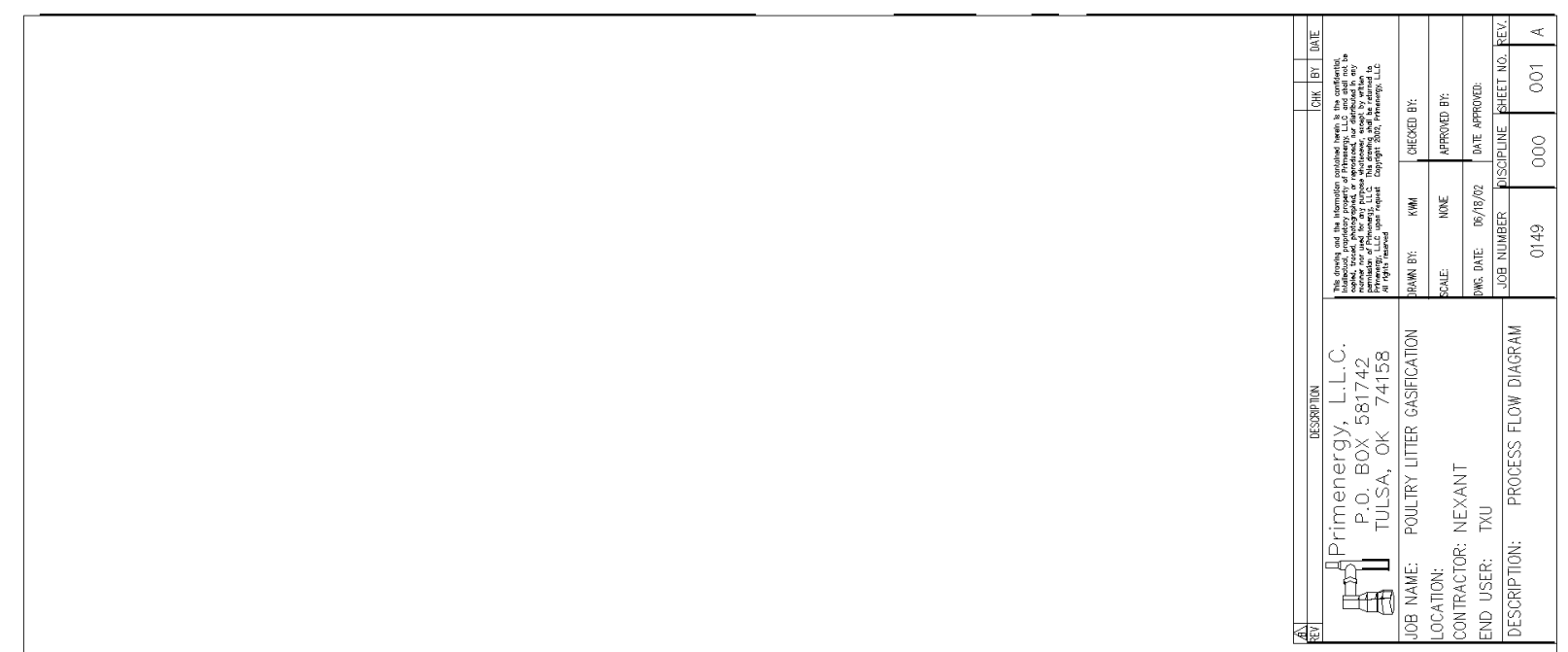

m

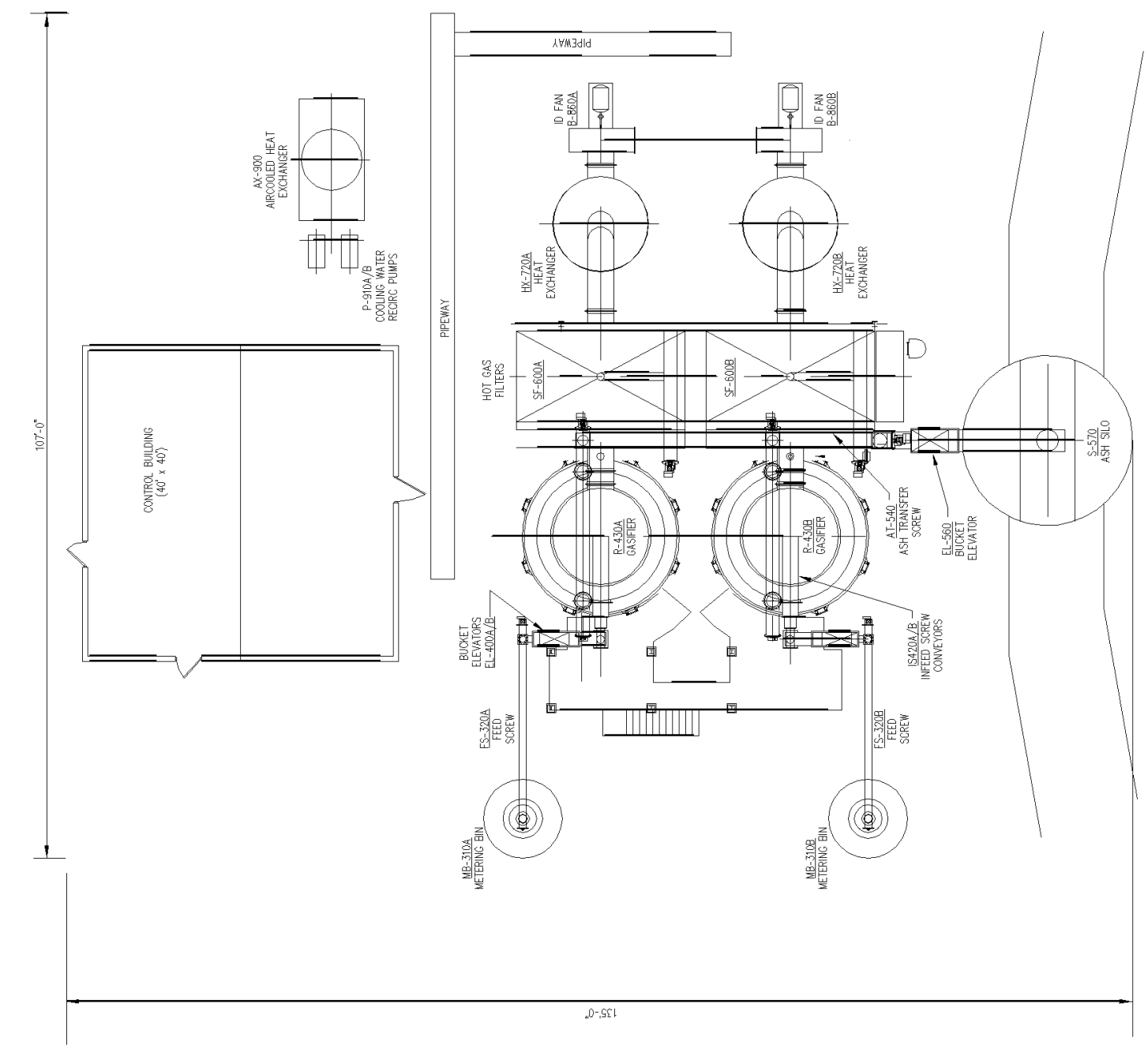

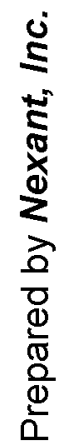




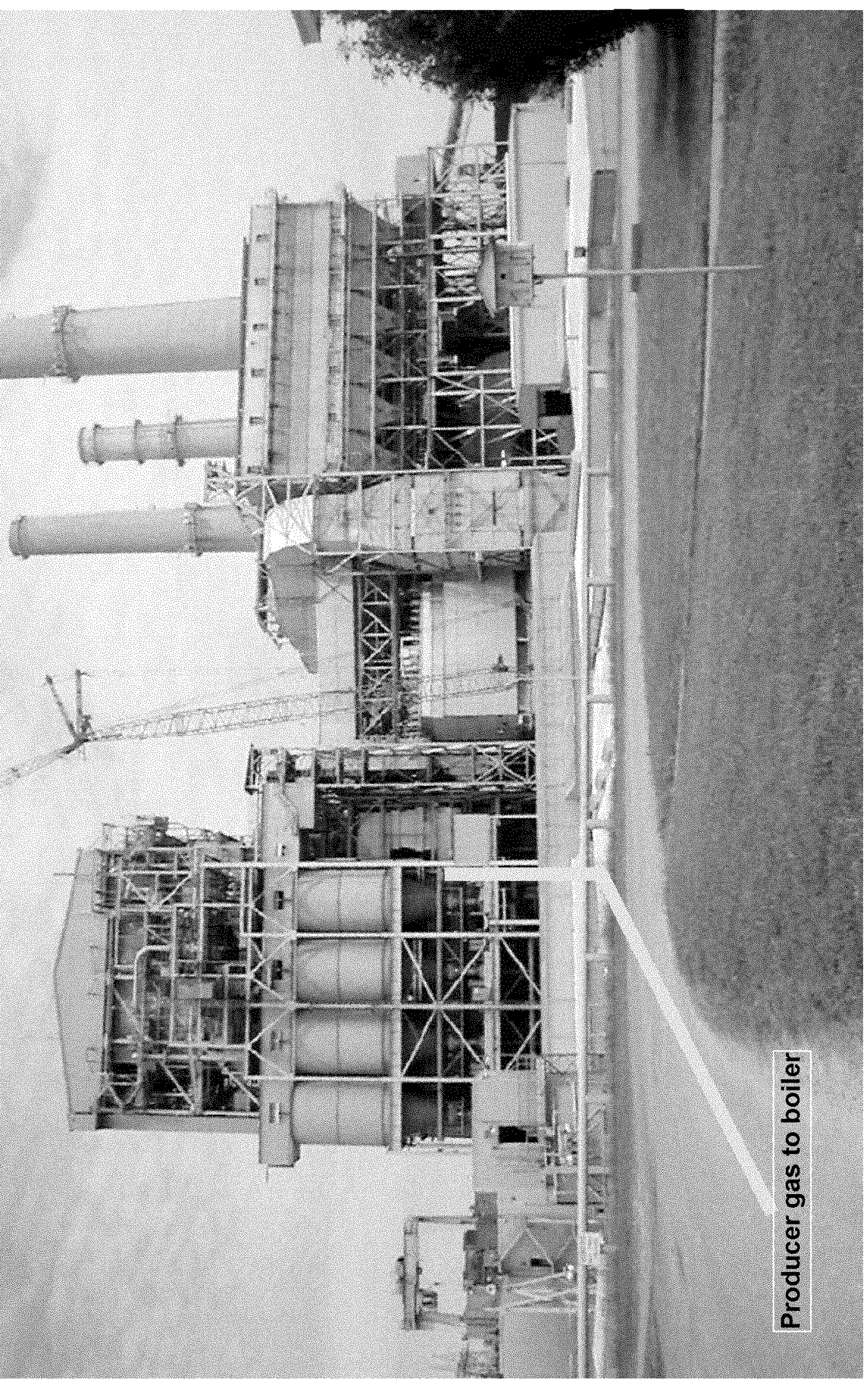

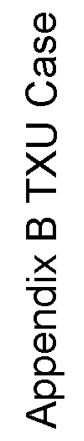

m

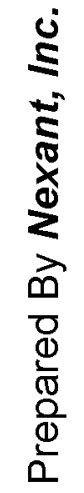




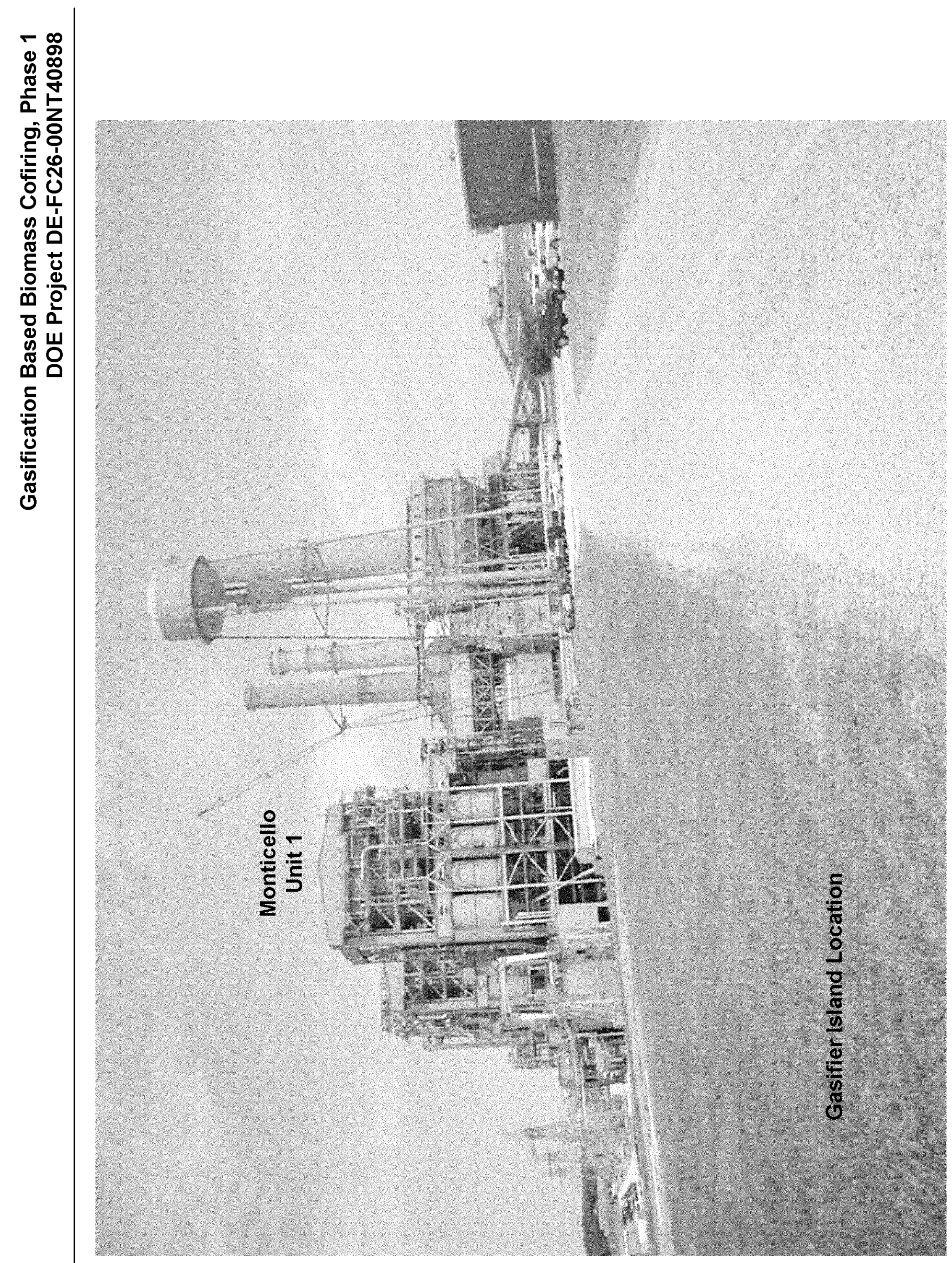

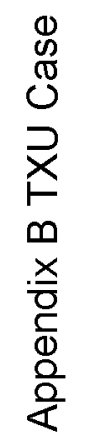

$\frac{0}{\infty}$ 

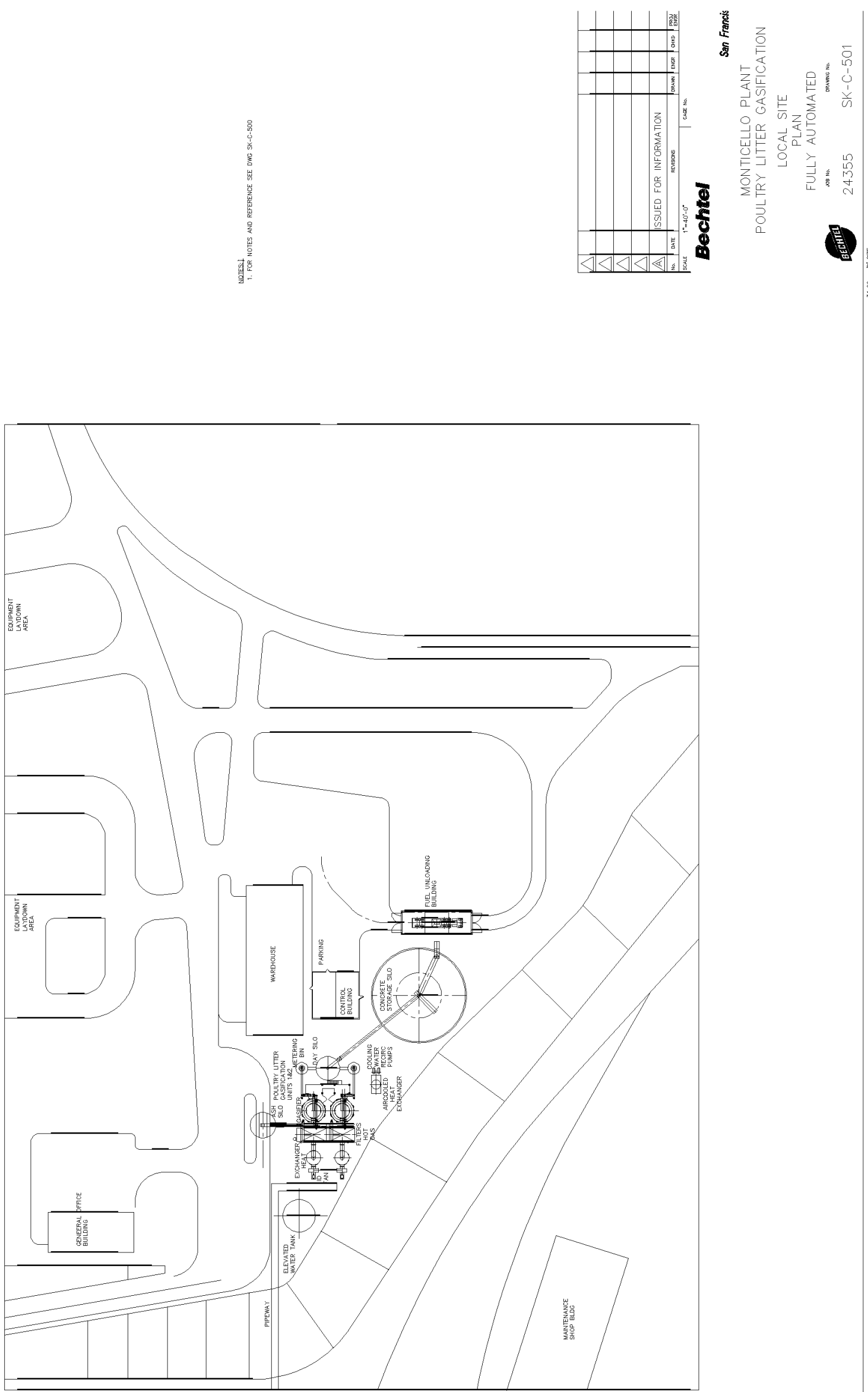

$\frac{N}{\frac{1}{m}}$

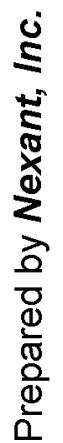



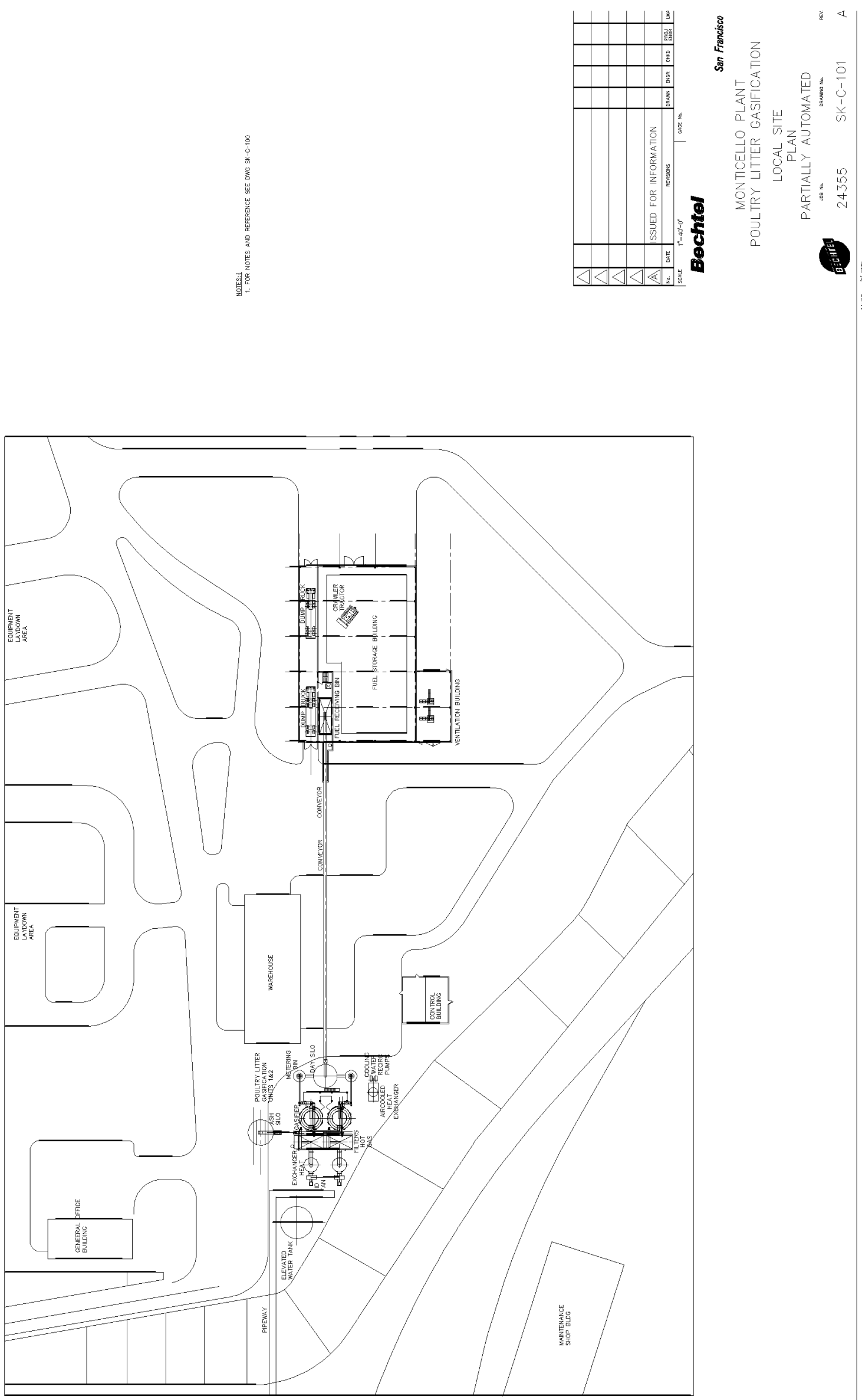

$\frac{m}{n}$

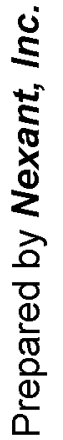




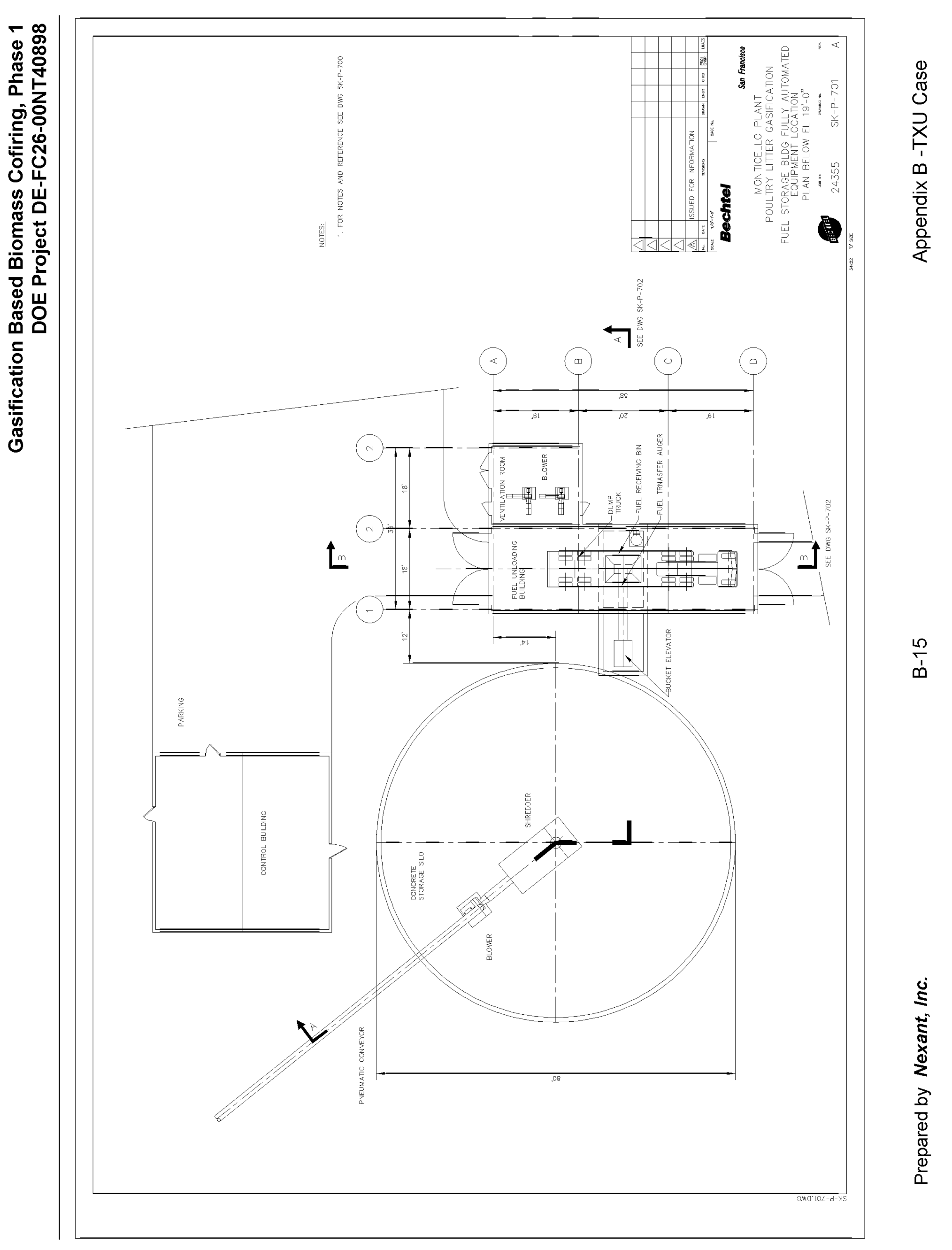




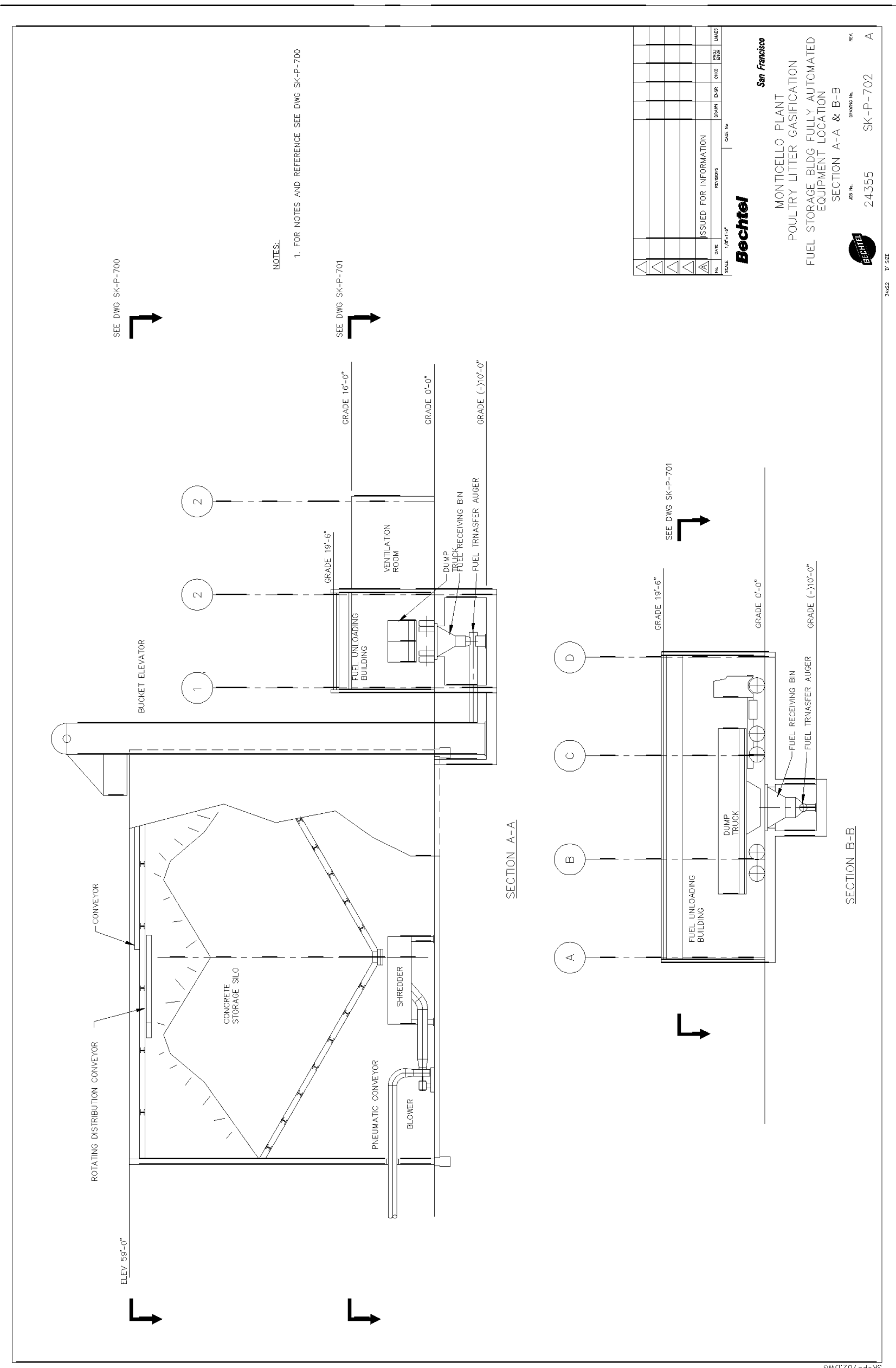

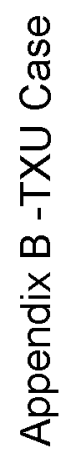

$\frac{\oplus}{\infty}$ 


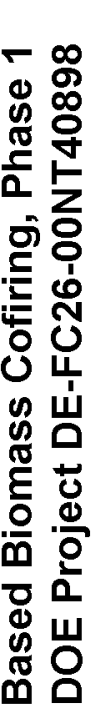

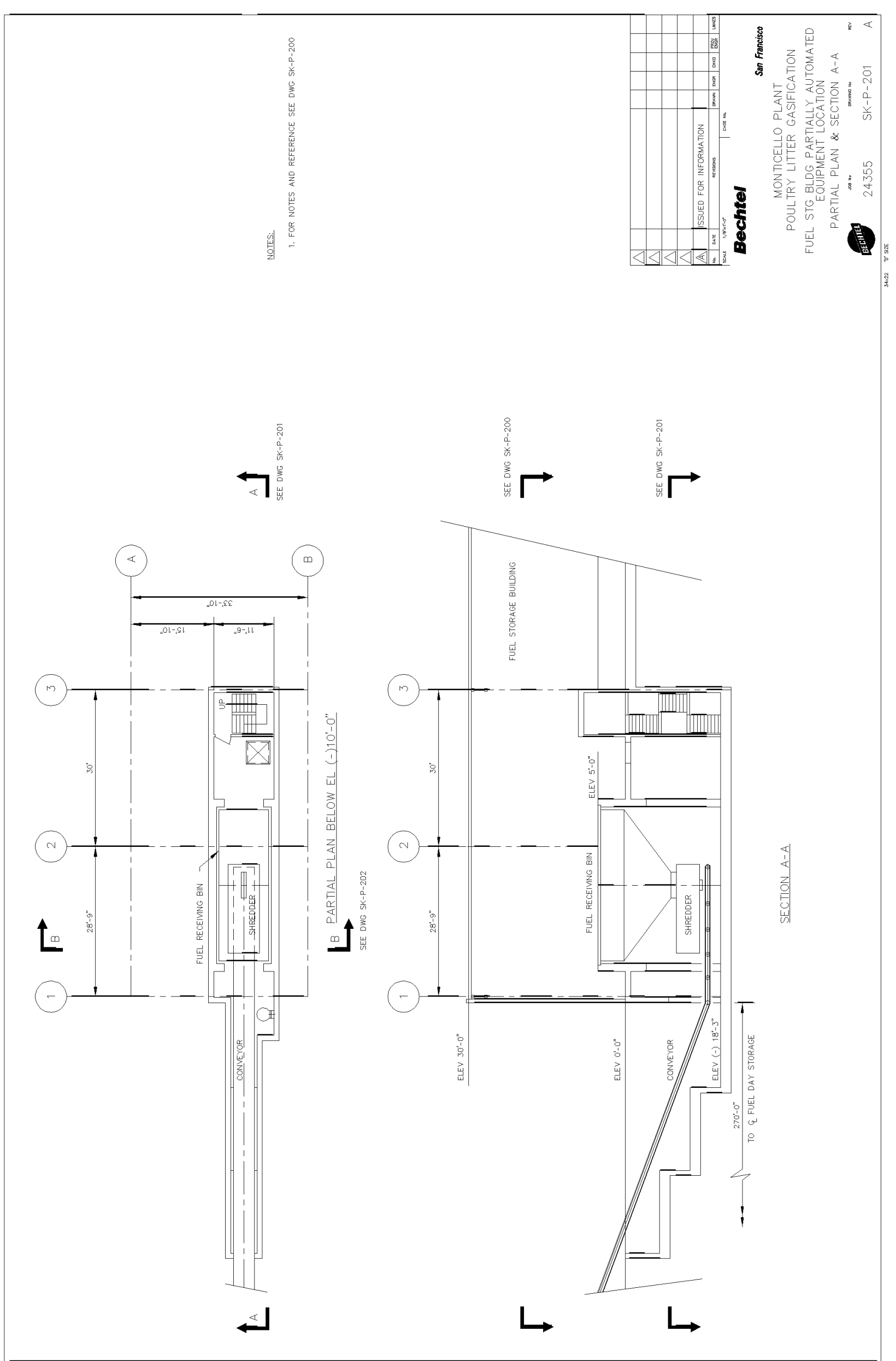

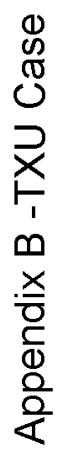

$\frac{\infty}{\infty}$

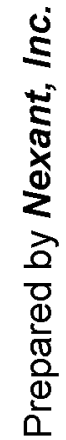


Appendix C - BB Power Report 
PRELIMINARY ENGINEERING STUDY FOR FEASIBILITY OF MODULAR BIO-GASIFIER HOT PRODUCER GAS INJECTION INTO PULVERIZED COAL FIRED

FLAT WALL FURNACE

\author{
FOR: \\ NEXANT INC. \\ AT \\ WESTERN KENTUCKY ENERGY \\ REID PLANT \\ SEBREE POWER COMPLEX \\ SEBREE, KENTUCKY
}

BBP CONTRACT No. 200756

Original Contract Riley Stoker Corp. B2502

Date Issued: 31 May 2001 


\title{
PRELIMINARY ENGINEERING STUDY FOR FEASIBILITY OF MODULAR BIO-GASIFIER HOT PRODUCER GAS INJECTION INTO PULVERIZED COAL FIRED FLAT WALL FURNACE
}

\author{
FOR \\ NEXANT INC. \\ AT \\ WESTERN KENTUCKY ENERGY \\ REID PLANT \\ SEBREE POWER COMPLEX \\ SEBREE, KENTUCKY
}

BBP CONTRACT NO. 200756

Original Contract Riley Stoker Corp. B2501

DATE ISSUED: 31 May 2001

Prepared By:

Prepared By:

$\frac{\text { Xum A Zovel } 2 \text { imay }^{\circ}}{\text { Frank Zone, Jr., P.E. }}$

Sr. Staff Engineer

Boiler Design

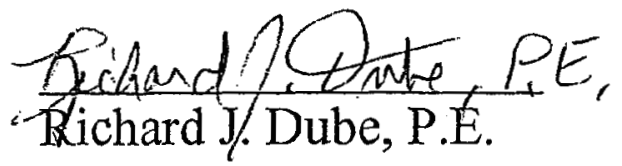

Sr. Consultant

Fuel Burning

Approved By:

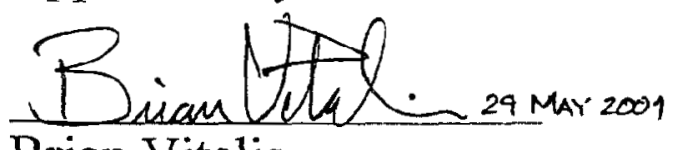

Brian Vitalis

Manager

Boiler Design 


\section{BABCOCK BORSIG POWER}

May 31, 2001

NEXANT, Inc.

45 Fremont Street, $7^{\text {th }}$ Floor

San Francisco, CA 94105-2210

Attn: Mr. Babul Patel

Subject: $\quad$ Phase 1 Engineering Study for Feasibility of Modular Bio-Gasifier Hot

Producer Gas Injection into Pulverized Coal Fired Flat Wall Furnace

At Western Kentucky Energy, Reid Plant

Sebree Power Complex, Sebree, Kentucky

NEXANT, Inc. PO \#0104-NEX-133

Original Contract Riley Stoker Corp, B2502

DB Riley Contract 200756

Dear Babul,

Thank you for using Babcock Borsig Power's engineering services; attached please find three copies of engineering's report that provides NEXANT assistance and recommendations in determining feasible locations, size, and number of penetrations required to flow syn gas into a pressurized type furnace.

As mentioned in today's conversation, once you have reviewed the report, call me a day ahead of time and I will set up a teleconference with engineering (Frank and Dick) to answer any questions that you may have.

Thank you for the opportunity to be of service to you, BBP looks forward to perhaps working with NEXANT on Phase 2 of this project.

Sincerely,

Babcock Borsig Power, Inc.

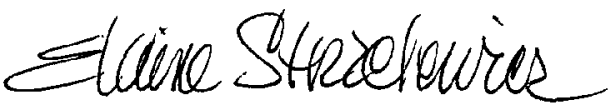

Elaine K. Strzelewicz

Job Manager, Field Engineering and Services Department

CC: K. Davis, P. Knight/1, J. Scott/1, E. Vega/1

Babcock Borsig Power, Inc.

Energy Systems and Services Division

Mailing Address:

Shipping Address:

Telephone: (508) 852-7100

5 Neponset Street 


\section{BABCOCK BORSIG POWER, INC.}

Nexant Inc.

WKE Reid Plant

BBP Contract 200756

DISTRIBUTION LIST

Nexant, Inc.
K. Davis
R. Dube
P. Knight
T. Martinko
J. Scott
E. Strzelewicz
E. Vega
B. Vitalis
F. Zone
Extra (3 Copies) 


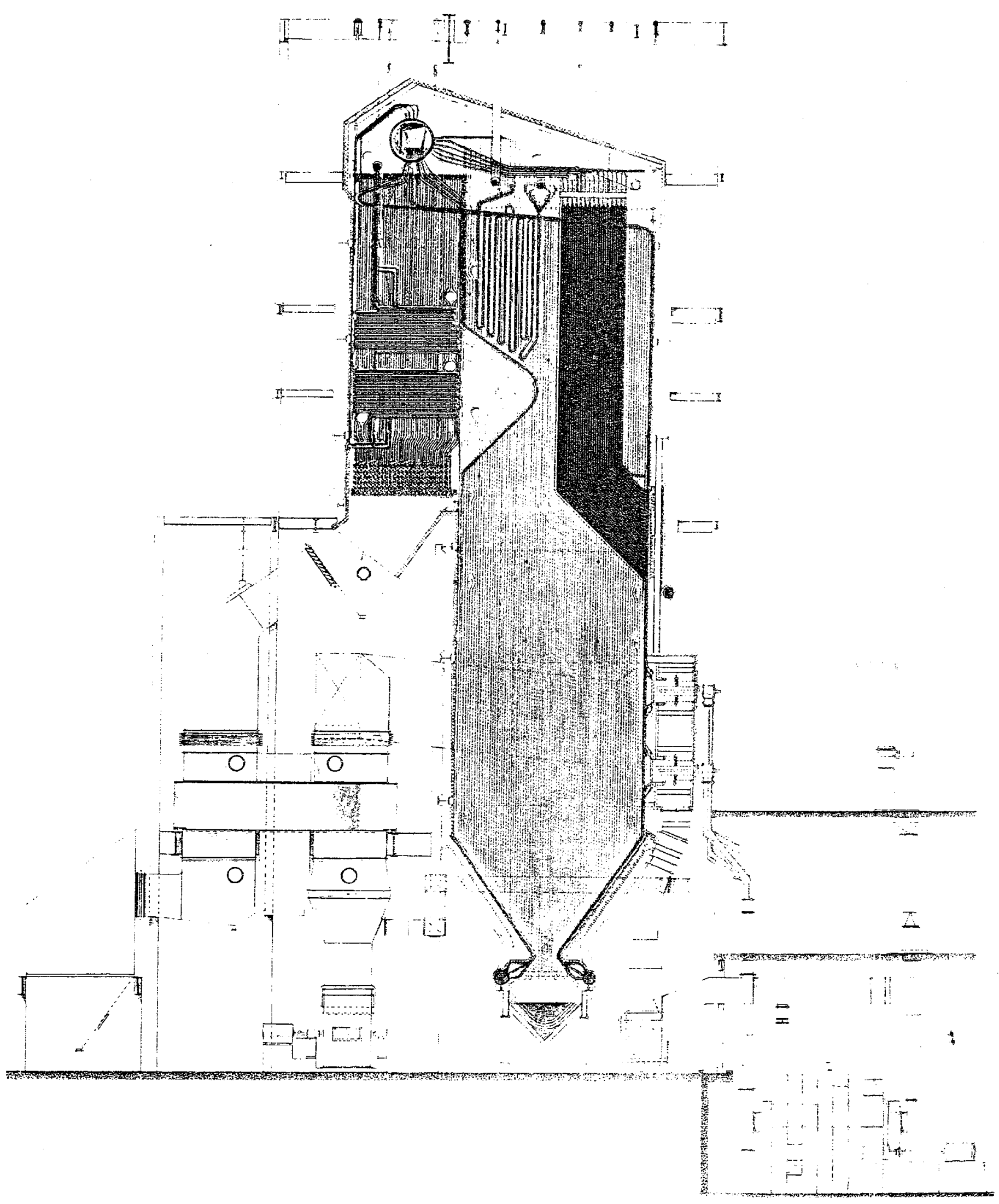

BIG RIVERS RURAL ELECTRIC COOPERATIVE CORP. SEBREE. KENTUCKY

690.000 lbs/hr-1475 psig design-1300 psig operating-055F

Burns \& McDonnell Engineering Co., Consulting Engineers 


\section{BABCOCK BORSIG POWER, INC.}

Nexant Inc.

WKE Reid Plant

BBP Contract 200756

\section{TABLE OF CONTENTS}

1.0 INTRODUCTION 1

1.1 Introduction 1

1.2 Background 2

2.0 EXECUTIVE SUMMARY 3

2.1 Objective 3

- 2.2 Findings and Conclusions 4

2.3 Recommendations 5

3.0 DISCUSSION 6

3.1 Description of Bio-Gasifier Process 6

3.2 Boiler Performance 12

3.3 Syn Gas Penetration Size Requirements 15

3.4 Boiler Syn Gas Penetration Location 18

3.5 Syn Gas Pressure Requirements 20

3.6 Preliminary Recommendations on Required

Stiffening/Strengthening at the Boiler Penetrations 21

4.0 APPENDICES 22

4.1 Original Boiler Performance 22

4.2 Communications 23 


\section{BABCOCK BORSIG POWER, INC.}

Nexant Inc.

WKE Reid Plant

BBP Contract 200756

\section{LIST OF TABLES}

1. Gasifier Process Streams

2. Boiler Performance

\section{LIST OF FIGURES}

1. Poultry Litter Gasification Process Schematic

2. Syn Gas Penetration Sizing Nomogram

3. Syn Gas Penetration Location 


\section{BABCOCK BORSIG POWER, INC.}

Nexant Inc.

WKE Reid Plant

BBP Contract 200756

\section{0 -INTRODUCTION AND BACKGROUND}

\subsection{Introduction}

NEXANT, Inc. and its partners, Western Kentucky Energy and Primenergy, are working with DOE-NETL to develop a biomass cofiring project at the Western Kentucky Energy Reid Plant located near Henderson, Kentucky. The cofiring project is a proposal for the installation of modular bio-gasifier(s) adjacent to the existing boiler and injecting the hot producer gas from the gasifier into the boiler. As part of phase 1, Nexant is seeking assistance in modeling the expected boiler operation post gasifier(s) installation. The specific tasks for BBP (subcontractor scope of work) as a part of phase 1 are as follows:

- Determine feasible locations for boiler penetration(s) to minimize the impact on existing boiler equipment

- $\quad$ Size the penetrations

- Determine pressure requirements at the penetrations

- $\quad$ Provide preliminary recommendations on required stiffening/strengthening at the boiler penetrations. 


\section{BABCOCK BORSIG POWER, INC.}

Nexant Inc.

WKE Reid Plant

BBP Contract 200756

\subsection{Background}

The Western Kentucky Energy Reid Plant was designed by Riley Stoker Corporation under contract B-2502 (1962). It consists of one steam generating unit at a maximum continuous rating of $690,000 \mathrm{Lb} / \mathrm{hr}$ steam flow, $1300 \mathrm{psig}$ outlet steam pressure, $955^{\circ} \mathrm{F}$ outlet steam temperature, $440^{\circ} \mathrm{F}$ feedwater temperature entering the economizer, while firing West Kentucky Bituminous coal. The boiler has two (2) Riley ball tube mills, eight (8) Riley type 60 flare burners, and one (1) Ljungstrom 25VIx48 air heater. 


\section{BABCOCK BORSIG POWER, INC.}

Nexant Inc.

WKE Reid Plant

BBP Contract 200756

\subsection{EXECUTIVE SUMMARY}

2.1 Objectives

The objectives of this preliminary engineering study are as follows:

- Determine the size and number of penetrations required to flow syr gas into the furnace.

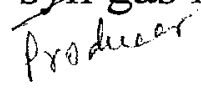

- Determine feasible locations for the penetrations in order to minimize the impact on existing boiler equipment.

- Determine the syr gas pressure requirements at the penetrations.

- $\quad$ Provide preliminary recommendations on required stiffening/strengthening at the penetrations. 


\section{BABCOCK BORSIG POWER, INC.}

Nexant Inc.

WKE Reid Plant

BBP Contract 200756

2.2 Findings and Conclusions

- The overfire combustion chamber stream 11 syn gas flow is $73,837 \mathrm{ACFM}$ at $2,400^{\circ} \mathrm{F}$. The selected velocity is 150 $\mathrm{ft} / \mathrm{sec}$ and total required cross sectional flow area is $8.204 \mathrm{ft}^{2}$. The conclusion is that 4 penetrations of 19.5 inch inside diameter will satisfy the total flow cross sectional area requirement.

- The most feasible locations for the penetrations are on the lower sidewalls of the furnace.

- The syn gas pressure requirement for stream 11 at the penetration is 10.0 i.w.c.

- The furnace expansion at the location of the 4 proposed penetrations from ambient rest position to MCR condition is 4.25 inch downward at the bottom and 0.75 inch towards the . side and front. Strengthening or stiffening for these expansions is not done, rather expansion joints are usually provided.

- The Nexant, Inc., proposed 38" OD syn gas transport piping (4 pipes) with an estimated $268^{\circ} \mathrm{F}$ outside surface temperature will require personnel protection to meet OSHA requirements and appropriate plant cooling/ventilation. 


\section{BABCOCK BORSIG POWER, INC.}

Nexant Inc.

WKE Reid Plant

BBP Contract 200756

\subsection{Recommendations}

- The penetration velocity of $150 \mathrm{ft} / \mathrm{sec}$, suggested by Nexant, Inc., should be increased to provide for smaller inside diameter and smaller outside diameter. This of course will require increased syn gas pressure at the penetration.

- The recommended velocity is $300 \mathrm{ft} / \mathrm{sec}$ and the inside diameter is 14 inch, 4 penetrations. The required pressure at the penetration is 12.6 i.w.c.

- The bio-gasifier stream 11 piping from the overfire combustion chamber to the furnace penetration must have expansion joints to accommodate the thermal movements of the furnace and to isolate piping loads from the furnace. The piping must have outside insulation to meet OSHA requirement of $130^{\circ} \mathrm{F}$ surface temperature.

- The selection of the penetration location on the lower sidewalls of the furnace was based upon space availability and practicality. A CFD flow model study should be done to investigate the flow of syn gas into the furnace during coal firing. 


\section{BABCOCK BORSIG POWER, INC.}

Nexant Inc.

WKE Reid Plant

BBP Contract 200756

\subsection{DISCUSSION}

\subsection{Description of Bio-Gasifier Process}

The bio-gasifier process utilizes poultry litter as primary fuel in conjunction with air and pilot gas to produce syn gas and residual ash. The poultry litter is delivered (via truck), stored in fuel storage house, unloaded to fuel silos, discharged to sizing screen (with hammermill recycle back to sizing screen, sent to metering bin, thence to bucket elevator, through to rotary valve, then to infeed conveyor, then to gasifier. A fan supplies underfire air to the gasifier and bottom ash is removed from the gasifier via conveyor to an ash silo. Gasifier product gas is water quenched prior to transport to a ceramic fiber filter process. Ash is removed from the ceramic fiber filter bucket via bottom valves and sent to the ash conveyor of the gasifier. The product gas then flows via an induced draft fan to an overfire combustion chamber. Overfire air, via a forced draft fan, and pilot gas are fed to the combustion chamber to produce syn gas. The syn gas then flows to a syn gas " burner chamber for combustion with pilot gas and air (via forced draft fan). The final product gas is intended for use in the boiler.

A schematic diagram of the poultry litter gasification process is shown in Figure 1. 


\section{BABCOCK BORSIG POWER, INC.}

Nexant Inc.

WKE Reid Plant

BBP Contract 200756

The three streams considered to be of interest for utilization in the boiler are stream $8\left(1381.8^{\circ} \mathrm{F}\right)$, stream $11\left(2400^{\circ} \mathrm{F}\right)$, and stream 14 $\left(2330.2^{\circ} \mathrm{F}\right)$ and the stream component flow rates are listed in Table 1.

Stream 8 is a gas mixture of carbon monoxide, carbon dioxide, hydrogen, water vapor, nitrogen, and sulfur dioxide. The mass flow rate is $41,505 \mathrm{Lb} / \mathrm{hr}$ and the volumetric flow rate is 37701 $\mathrm{ACFM}$ at $1381.8^{\circ} \mathrm{F}$. Not included in the flow stream are amines (small amount) as a result of the gasification process. The sensible heat of stream 8 is $429 \mathrm{Btu} / \mathrm{Lb}$.

Stream 11 is a gaseous mixture of carbon monoxide, carbon dioxide, hydrogen, water vapor, and nitrogen. The mass flow rate is $57,440 \mathrm{Lb} / \mathrm{hr}$ and the volumetric flow rate is $74,129 \mathrm{ACFM}$ at $2400^{\circ} \mathrm{F}$. The sensible heat of stream 11 is $760 \mathrm{Btu} / \mathrm{Lb}$.

Stream 14 is a gaseous mixture of carbon dioxide, water vapor, nitrogen, and oxygen. The mass flow rate is $82,588 \mathrm{Lb} / \mathrm{hr}$ and the volumetric flow rate is $100,000 \mathrm{ACFM}$ at $2330^{\circ} \mathrm{F}$. The sensible heat of stream 14 is $693 \mathrm{Btu} / \mathrm{Lb}$. Stream 14 has no chemical heat (i.e., $\mathrm{HHV}=0$ ) 


\section{BABCOCK BORSIG POWER, INC.}

Nexant Inc.

WKE Reid Plant

BBP Contract 200756

Stream 8 and stream 11 have chemical heating value of up to 100 $\mathrm{Btu} / \mathrm{Lb}$ (HHV). There is no chemical heating value for stream 14 because the gaseous mixture is composed of oxygen and inerts.

The original background information from Nexant, Inc., noted that the syn gas for boiler utilization would have a heating value of $100 \mathrm{Btu} / \mathrm{Scf}$ and sensible heat value at $1000^{\circ} \mathrm{F}$ stream temperature as injected into the boilers.

The syn gas of stream 8 has amines (nitrosamines, etc.) and when injected into the furnace may produce NOx because of the bound nitrogen in this chemical species group.

The syn gas of stream 14 is basically inert and therefore has no chemical heating value. Elimination of the final bio gas process combustion chamber will reduce the size, cost, etc., of the process and therefore this stream would not be available. In essence, this stream would be similar to flue gas recirculation.

Stream 11 is the main choice of Nexant, Inc. and is a better choice than stream 14 because that the volumetric flow rate of stream 11 is much less (approximately $26 \%$ ) than the volumetric flow rate of stream 14. 


\section{BABCOCK BORSIG POWER, INC.}

Nexant Inc.

WKE Reid Plant

BBP Contract 200756

However, the temperature of stream 11 is $70 \mathrm{~F}^{\circ}$ greater than stream 14 (i.e. $2400^{\circ} \mathrm{F}-2330^{\circ} \mathrm{F}=70 \mathrm{~F}^{\circ}$ ) and higher temperatures place more limitations on material selection (metals and refractories/insulation) than do lower temperature flowing media.

Actually streams 11 and 14 are much higher in temperature than normally encountered in conventional boiler practice for external boilers connections. Conventionally external boiler convections seldom exceed $1000^{\circ} \mathrm{F}$. Such high temperatures present materials, insulation, and expansion difficulties. 
Nexant, Inc.

WKE Reid Plant

BBP Contract 200756

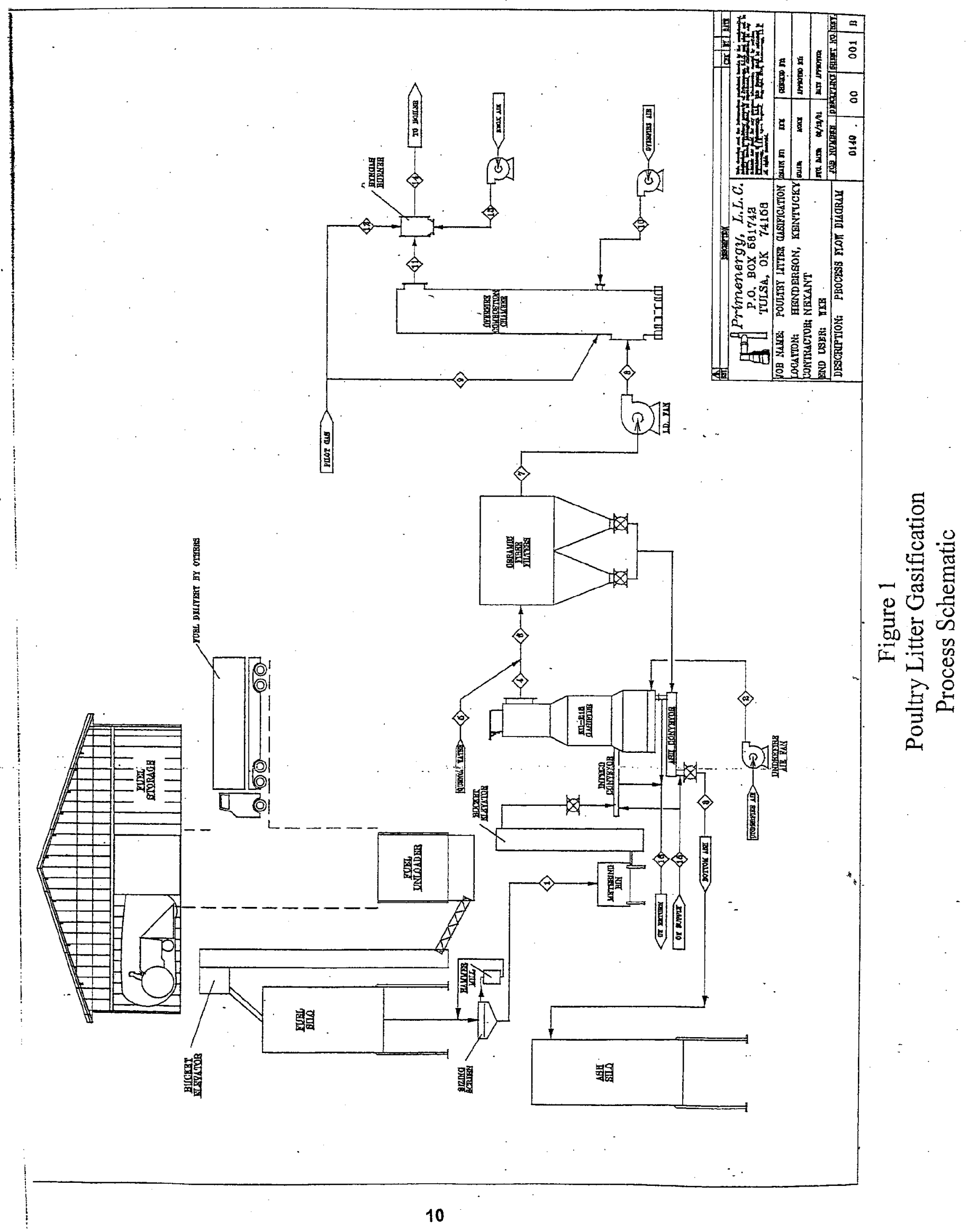




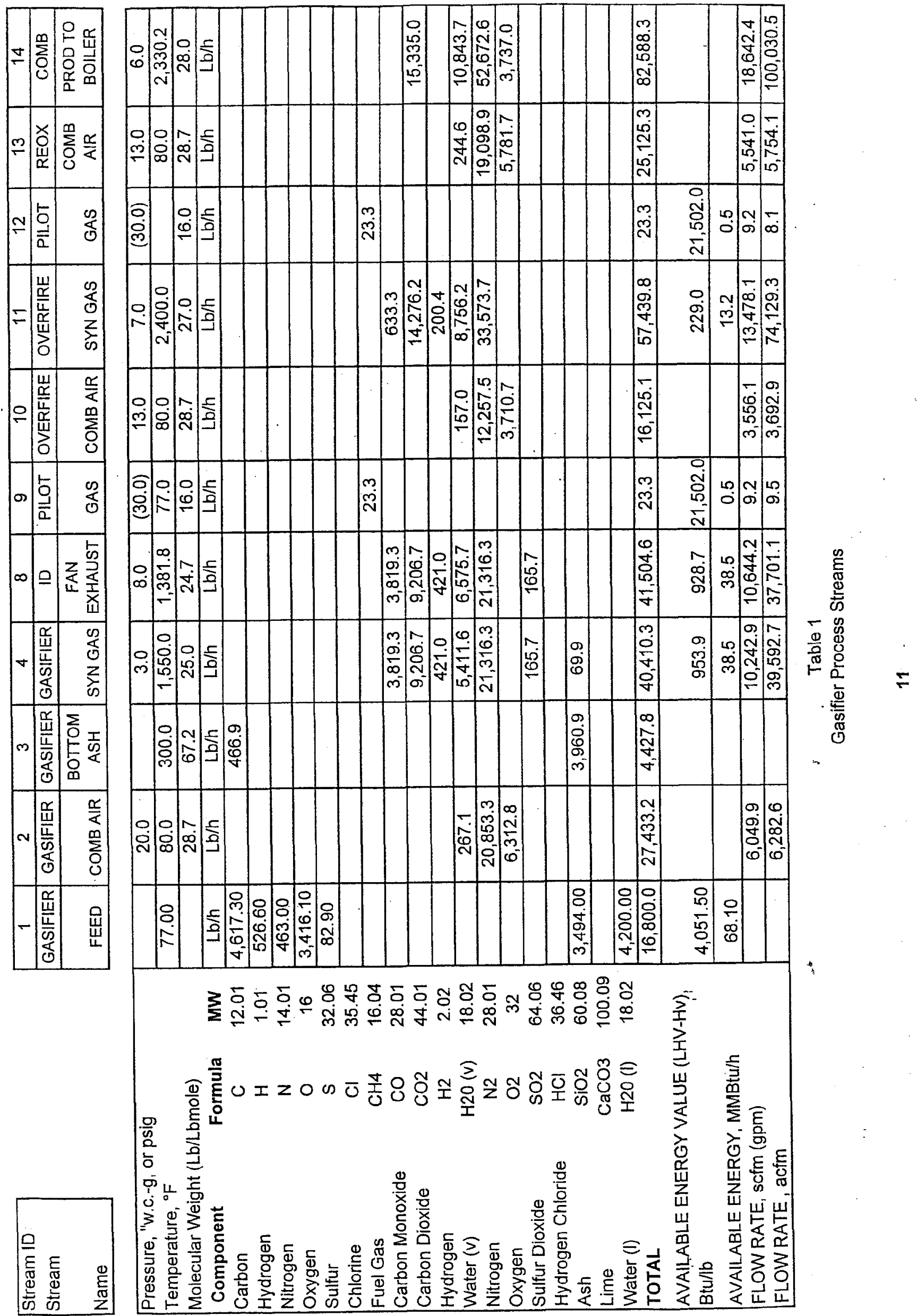




\section{BABCOCK BORSIG POWER, INC.}

Nexant Inc.

WKE Reid Plant

BBP Contract 200756

\subsection{Boiler Performance}

Boiler heat and mass balance calculations were performed for original boiler performance conditions at $100 \%$ load, stream 8 and coal at $100 \%$ load, stream 11 and coal at $100 \%$ load, and stream 14 and coal at $100 \%$ load. The original boiler performance sheet is shown in the Appendix. The boiler conditions at $100 \%$ load (MCR) are $640,000 \mathrm{Lb} / \mathrm{hr}$ steam flow, $955^{\circ} \mathrm{F}$ outlet steam temperature, 1300 psig outlet steam pressure, $440{ }^{\circ} \mathrm{F}$ feedwater temperature, $343^{\circ} \mathrm{F}$ stack temperature (undiluted), ambient air temperature $80^{\circ} \mathrm{F}$, and $22 \%$ excess air (total). The boiler efficiencies are $86.55 \%$ (original, coal only), $85.77 \%$ (stream 8 and coal), $85.43 \%$ (stream 11 and coal), and $85.82 \%$ (stream 14 and coal).

The split of heat input by fuel is as follows: $100 \%$ coal (original), $91 \%$ coal/9 \% Syn Gas (coal and stream 8 ), $94 \%$ coal/6 \% Syn Gas (coal and stream 11), and $94 \%$ coal $/ 6 \%$ Syn Gas (coal and stream 14). The coal flows for comparison are $71,316 \mathrm{Lb} / \mathrm{hr}$ (original) 64,932 Lb/hr (stream 8), 67,218 Lb/hr (stream 11), and 66,943 $\mathrm{Lb} / \mathrm{hr}$ (stream 14).

The EPRS heat release and the volumetric heat release are virtually the same for all cases. The furnace exit gas temperature (FEGT) is $1,870^{\circ} \mathrm{F}$ (original), $1,861^{\circ} \mathrm{F}$ (stream 8 ), 1,850 ${ }^{\circ} \mathrm{F}$ (stream 11), and 


\section{BABCOCK BORSIG POWER, INC.}

Nexant Inc.

WKE Reid Plant

BBP Contract 200756

$1,846^{\circ} \mathrm{F}$ (stream 14) for a decrease of $9^{\circ} \mathrm{F}, 20^{\circ} \mathrm{F}$. and $24^{\circ} \mathrm{F}$ for stream 8,11 , and 14 , respectively. The change in furnace flue gas flow relative to original furnace flue gas flow is $-0.2 \%$ (stream 8 ), $+2.6 \%$ (stream 11$)$, and $+4.0 \%$ (stream 14). These small changes in FEGT and furnace flue gas flows indicate the back pass (i.e. rear convection pass) of the boiler will perform similar to the original case and result in a similar stack temperature and therefore, yield the predicated boiler efficiencies. Therefore the boiler performance and efficiency is not expected to change for all four cases studied.

The furnace is a pressurized type and the pressure is +9.1 i.w.c. At $100 \% \mathrm{MCR}$ as per original contract design. The expected syn gas port pressure at the port exit plane of furnace entry is the sum of furnace pressure and one velocity pressure head of flowing syn gas as shown in Table 2 (i.e., 10.3 i.w.c. stream 8, 9.95 i.w.c. stream 11 , and 10.0 i.w.c. stream 14). The calculated ACFM's of syn gas , are 37,553 stream $8,73,837$ stream 11 , and 99,635 stream 14. For the case of syn gas port velocity of $150 \mathrm{ft} / \mathrm{sec}(9,000 \mathrm{ft} / \mathrm{min})$ and the selection of 4 ports, the syn gas port inside diameters are 14 inch (stream 8), 19.5 inch (stream 11), and 22.5 inch (stream 14). 
Item

\begin{tabular}{|l|l|l|l|}
\hline Original & Stream 8 \\
\hline
\end{tabular}

\begin{tabular}{|l|}
\hline Boiler Load \\
Steam Flow \\
Outlet Steam Temperature \\
Outlet Steam Pressure \\
FW Temperature \\
Stack Temperature (Undiluated) \\
Stack Temperature (Diluated) \\
Ambient Air (R eference) \\
Boiler Effeciency(With margin) \\
Excess Air
\end{tabular}

\begin{tabular}{|c|c|c|c|c|}
\hline$\%$ & 100 & 100 & 100 & 100 \\
\hline $\mathrm{Lb} / \mathrm{hr}$ & 690,000 & 690,000 & 690,000 & 690,000 \\
\hline${ }^{\circ} \mathrm{F}$ & 955 & 955 & 955 & 955 \\
\hline PSIG & 1,300 & 1,300 & 1,300 & 1,300 \\
\hline${ }^{\circ} \mathrm{F}$ & 440 & 440 & 440 & 440 \\
\hline${ }^{\circ} \mathrm{F}$ & 343 & 343 & 343 & 343 \\
\hline${ }^{\circ} \mathrm{F}$ & 328 & 328 & 328 & 328 \\
\hline${ }^{\circ} \mathrm{F}$ & 80 & 80 & 80 & 80 \\
\hline$\%$ & 86.55 & 85.77 & 85.43 & 85.82 \\
\hline$\%$ & 22 & 22 & 22 & 22 \\
\hline
\end{tabular}

Coal Flow

Syn Gas Flow

Coal HHV

Syn Gas HHV

Syn Gas Sensible Heat

Syn Gas Temperature

Heat Input By Coal

Heat Input by Syn Gas

\begin{tabular}{|c|c|c|c|c|}
\hline $\mathrm{Lb} / \mathrm{hr}$ & 71,316 & 64,932 & 67,218 & 66,943 \\
\hline $\mathrm{Lb} / \mathrm{hr}$ & 0 & 41,505 & 57,440 & 82,588 \\
\hline $\mathrm{Btu} / \mathrm{Ft}$ & 11,600 & 11,600 & 11,600 & 11,600 \\
\hline $\mathrm{Btu} / \mathrm{Ft}^{3}$ & - & 100 & 18 & $\overline{0}$ \\
\hline Btu/Lb & - & 429.61 & 759.96 & 693.4 \\
\hline${ }^{\circ} \mathrm{F}$ & - & 1381.8 & 2400 & 2330.2 \\
\hline$\%$ & 100 & 91.048 & 94.253 & 93.868 \\
\hline$\%$ & - & 8.952 & 5.747 & 6.132 \\
\hline
\end{tabular}

\begin{tabular}{|c|c|c|c|c|c|}
\hline \multirow{6}{*}{$\begin{array}{l}\text { EPRS Hr } \\
\text { Vol Hr } \\
\text { Total Furnace Flue Gas } \\
\text { FEGT } \\
\triangle \text { FEGT } \\
\triangle \text { Furnace Flue Gas }\end{array}$} & $\mathrm{Btu} / \mathrm{hr} \mathrm{Ft}^{2}$ & 68,427 & 67,914 & 67,918 & 67,805 \\
\hline & Btu/hr Ft ${ }^{3}$ & 14,517 & 14,647 & 14,705 & 14,437 \\
\hline & $\mathrm{Lb} / \mathrm{hr}$ & 810,244 & 808,729 & 831,546 & 843,148 \\
\hline & ${ }^{\circ} \mathrm{F}$ & 1,870 & 1,861 & 1,850 & 1,846 \\
\hline & ${ }^{\circ} \mathrm{F}$ & -- & -9 & -20 & -24 \\
\hline & $\%$ & - & -0.2 & +2.6 & +4.0 \\
\hline
\end{tabular}

\begin{tabular}{|c|c|c|c|c|c|}
\hline \multirow{7}{*}{$\begin{array}{l}\text { Furnace Pressure } \\
\text { Syn Gas Pressure @ Port } \\
\text { Total Syn Gas Flow } \\
\text { Syn Gas Port Velocity } \\
\text { No of Syn Gas Ports } \\
\text { Syn Gas Port Inside Diameter } \\
\text { Syn Gas Port Inside Diameter }\end{array}$} & i.w.c. & 9.05 & 9.05 & 9.05 & 9.05 \\
\hline & i.w.c. & - & 10.3 & 9.95 & 10 \\
\hline & ACFM & -- & 37,553 & 73,837 & 99,635 \\
\hline & $\mathrm{Ft} / \mathrm{sec}$ & - & 150 & 150 & 150 \\
\hline & - & -- & 4 & 4 & 4 \\
\hline & $\mathrm{Ft}$ & -- & 1.152 & 1.616 & 1.88 \\
\hline & In & $\ldots$ & 14 & 19.5 & 22.5 \\
\hline
\end{tabular}

Table 2

Boiler Performance 


\section{BABCOCK BORSIG POWER, INC.}

Nexant Inc.

WKE Reid Plant

BBP Contract 200756

3.3 Syn Gas Penetration Size Requirements

The syn gas penetration size requirements are port size (inside diameter and outside diameter) and the number of ports for a total flow cross sectional area to satisfy the volumetric flow rate at specified temperatures at an assumed port velocity (i.e. inside diameter flowing velocity). A syn gas penetration sizing nomogram is shown in Figure 2. The entering arguments are flow ACFM, variable velocity $(\mathrm{ft} / \mathrm{sec})$, total flow area $\left(\mathrm{ft}^{2}\right)$, number of penetrations, and the result is penetration inside diameter.

The specific case of interest for Nexant, Inc., is stream 11 flowing $73,837 \mathrm{ACFM}$ at $150 \mathrm{ft} / \mathrm{sec}$ and $2,400^{\circ} \mathrm{F}$. This results in a total penetration inside cross sectional area of $8.204 \mathrm{ft}^{2}$ and with 4 penetrations, the inside cross sectional area of each penetration is $2.051 \mathrm{ft}^{2}$ which converts to an inside diameter of $1.62 \mathrm{ft}$ (i.e. 19.5 inch). However, at $300 \mathrm{ft} / \mathrm{sec}$ the inside diameter is 14 inch, which is less than 19.5 inch.

The outside diameter is determined by the thickness of the outside shell (pipe or tube), inside refractory lining, inside high temperature insulation, and outside low temperature insulation. At the $100 \%$ load condition (MCR), the drum pressure is 1,366 psig and the drum saturation is $585^{\circ} \mathrm{F}$ and the furnace wall tubes are slightly less than $585^{\circ} \mathrm{F}$ on the insulated side. It is good boiler $-z$ 


\section{BABCOCK BORSIG POWER, INC.}

Nexant Inc.

WKE Reid Plant

BBP Contract 200756

$+0$

the tube/tube wall fin combination and selected metal attachment to the tube/tube wall fin for reasons of thermal expansion stress. Also it is BBP practice in design to meet all OSHA requirements of $130^{\circ} \mathrm{F}$ (maximum surface temperature) for pipes/tubes accesible to personnel. The method for estimating the heat loss per $\mathrm{ft}$ of pipe/tube length is to estimate inside film convective heat transfer coefficient, outside combined radiation and natural convection heat transfer coefficients, select insulating and refractory material thickness and internal conductivity, and perform the calculation for a series of concentric annuli with hot gas flowing on the inside and $80^{\circ} \mathrm{F}$ ambient air on the outside.

BBP has performed these calculations and is basically in agreement with the method used by Nexant, Inc., i.e., a good first approximation to the overall pipe outside diameter is 38 inch for the 19.5 inch ID of stream 11 flowing 73,837 ACFM at $150 \mathrm{ft} / \mathrm{sec}$ at $2,400^{\circ} \mathrm{F}$.

For the 38 inch outside diameter Nexant, Inc. reports an outside surface temperature of $268^{\circ} \mathrm{F}$ which exceeds OSHA requirements of $130^{\circ} \mathrm{F}$. If this design is to be used, special consideration to personnel protection and appropriate plant ventilation/cooling would be needed. 

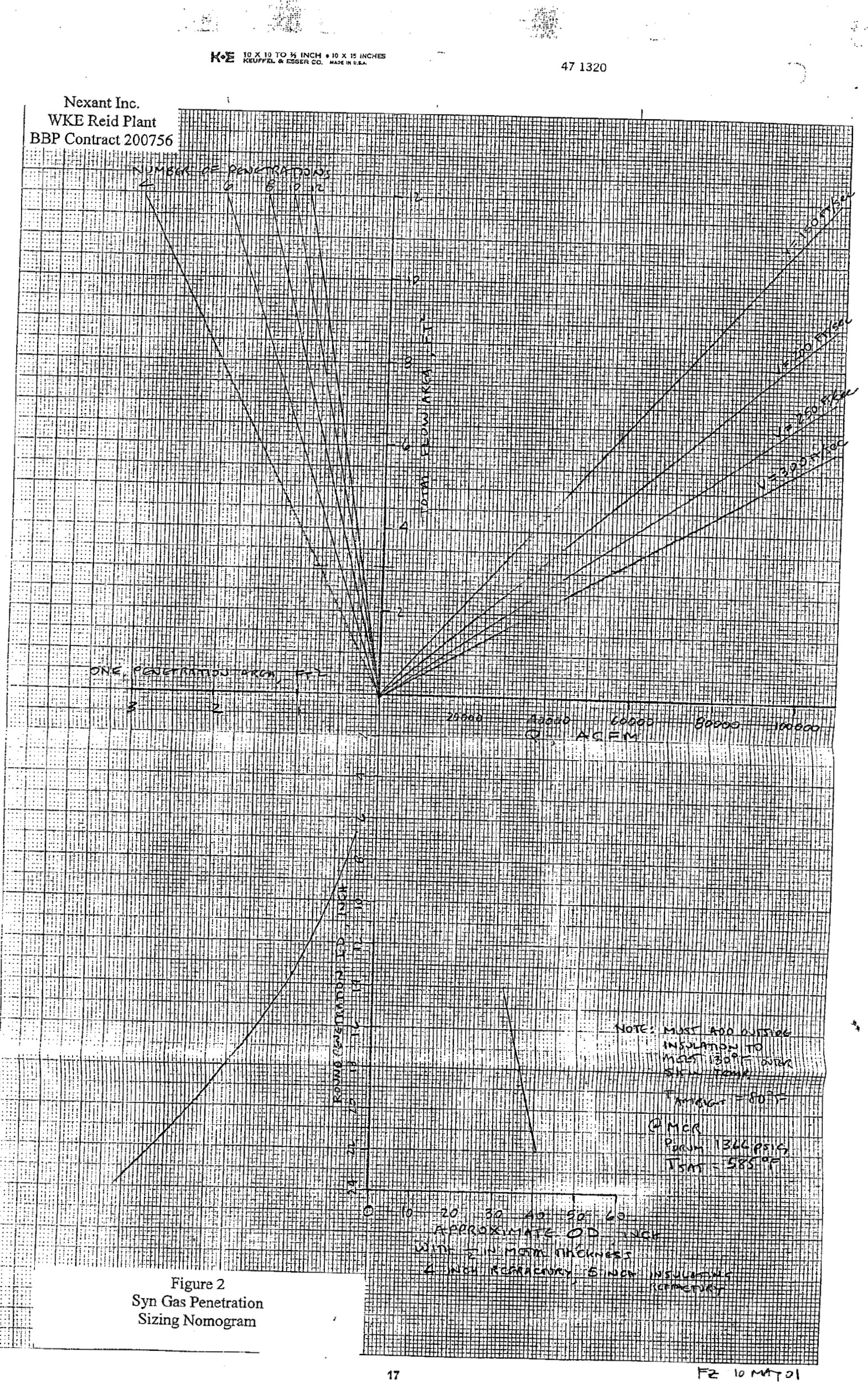


\section{BABCOCK BORSIG POWER, INC.}

Nexant Inc.

WKE Reid Plant

BBP Contract 200756

\subsection{Boiler Syn Gas Penetration Location}

A boiler side elevation view is shown in the front of this report and should be referred to during this description of the penetration(s) locations. The rear convection pass of the boiler is located under the drum and above the air heater. The forced draft fan is located at ground level underneath the air heater. The Riley ball tube mills (2), pulverized coal transport pipes, coal silo(s), and raw coal transport pipes are located on the front side of the boiler as are the eight (8) Riley flare burners and windbox. Also located on the front wall above the top of the windbox is the supply header for the four(4) furnace water wall platens. There are two main downcomers, one on each side, from the drum to the bottom furnace water wall headers. These downcomers are $21 \frac{1}{2}$ inch pipes and the main centerline (vertical) is approximately $6 \mathrm{ft}$ from the rear water wall tube centerline towards the front water wall.

The selected area for location of the penetrations is on the side walls, from elevation $452 \mathrm{ft} 6$ in to elevation $457 \mathrm{ft} 6$, and from the furnace side wall center to $7 \frac{1}{2} \mathrm{ft}$ towards the front on each side wall. Therefore, the available area is $5 \mathrm{ft} \times 10 \mathrm{ft}=50 \mathrm{ft}^{2}$ on either side wall to locate 2 penetrations in each area for a total of 4 penetrations at elevation $455 \mathrm{ft}$. The penetration location is shown in the sketch of Figure 3. 


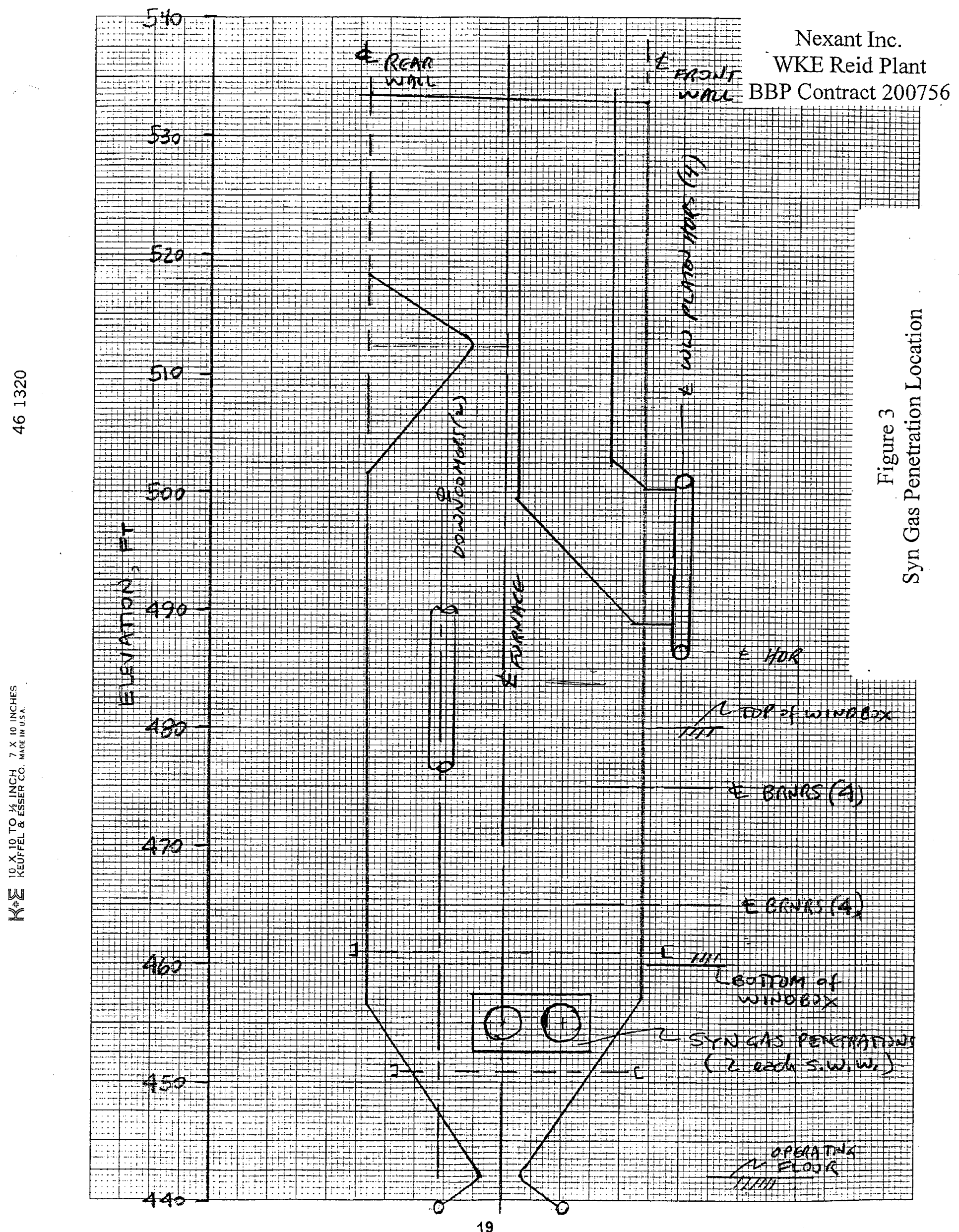




\section{BABCOCK BORSIG POWER, INC.}

Nexant Inc.

WKE Reid Plant

BBP Contract 200756

3.5 Syn Gas Pressure Requirements

At $100 \%$ load, the furnace design flue gas pressure is +9.05 i.w.c. and the syn gas penetration static pressure at the plane of injection into the furnace is $10.3 \mathrm{i}$.w.c. (stream 8), 10.0 i.w.c. (stream 11), and 10.0 i.w.c. (stream 14).

Presently, stream 11 is the item of interest by Nexant, Inc., and therefore the static pressure is 10.0 i.w.c. for a syn gas velocity of $150 \mathrm{ft} / \mathrm{sec}$ and volumetric flow rate of 73,837 ACFM utilizing a total of four (4) penetrations into the furnace. However, at 300 $\mathrm{ft} / \mathrm{sec}$ the static pressure is 12.6 i.w.c. at the penetration. 
BABCOCK BORSIG POWER, INC.

Nexant Inc.

WKE Reid Plant

BBP Contract 200756

3.6 Preliminary Recommendations on Required

Stiffening/Strengthening at the Boiler Penetrations

The drum centerline is at elevation $543 \mathrm{ft} 6$ in and the centerline of the furnace waterwall headers is at elevation $439 \mathrm{ft} 0$ in. The vertical expansion of the furnace is 5 inch downward at elevation $439 \mathrm{ft} 0$ in. The expected expansion at elevation $455 \mathrm{ft} 0$ in elevation is $4 \frac{1}{4}$ inch downward.

The horizontal expansion from the boiler rear wall to the furnace front water wall is $11 / 8$ inch. The horizontal expansion to the left and to the right about the centerline of the furnace is $3 / 4$ inch at the left side water wall and $3 / 4$ inch at the right side water wall. The approximate expansion at the centerline locations of the penetrations on the furnace side water walls are $3 / 4$ inch outward and $3 / 4$ inch towards front of furnace.

The syn gas piping must have expansion joints to accommodate the boiler/furnace expansions expected at the location of the penetrations. By locating the expansion joints close to the furnace, piping loads are not transferred to furnace walls. Waterwall penetrations would likely be similar to standard boiler openings whereby bent tubes and scallop plates form a rigid structure on the furnace wall. 


\section{BABCOCK BORSIG POWER, INC.}

Nexant Inc.

WKE Reid Plant

BBP Contract 200756

\subsection{APPENDICES}

\subsection{Original Boiler Performance}




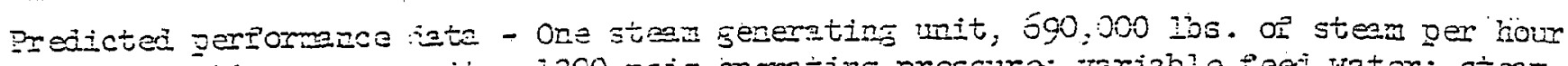

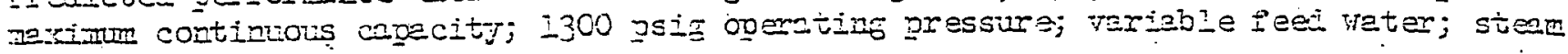
teruperature $955 \mathrm{~F}$.

trei - Coal, Hest Kentucis Bituminous; Hoist. I0.0; T.M. 34.9; P.C. 43.I; Ash I2.0; 11,600

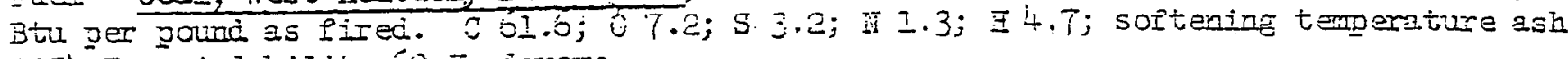
2254 I; gxindabilitif 50 Eeragrove.

1. Pounds of stem per hour act. evap. IT2,500

2. Feed weter temperature, $\vec{F}$.<smiles>CCCCC(C)C</smiles>

4 Tour Pea: Top titr Out

3. K Btu in stean ajove $i^{7}$. W. temp.

4. Tenp. ol gases leving Iurnece, $\vec{F}$.

5. $\mathrm{CO}_{2}$ in boiler exit gases

6. d excess air in boiler exit gases

7. Temp. ol gases entering economizer, F.

3. Temp. of economizer exit gases, $i$.

9. Tenp. of water entering economizer, F.

1\%. Term. or weter ieving economizer, $?$.

12. Water pressure drop tbru economizer, psi

12. Terp. of air henter exit gases, $F$. (Uncorrected)

Temp. oi air heater exit gașes, $F$. (Corrected)

i4. Terp. oi $2 i r$ entering heetar, $\vec{F}$

15. Temp. of air (arioient), F.

16. Terp. of atr Ieeving heater, F-

17. Total sten temperature leqving. superheeter, F.

13. Stean pressure droo thru superneeter and control, gsi

19. Boiler arm oressure, psig

20. Pressure drop thru economizer

21. Pressure drop tbru superheater

22. Pressure drop thru dust collector

23. Pressure drop thru steem coll

24. Pressure drop thru air heeter (gas side)

25. Pressure drop thru air heeter (air side)

26. Pressure Aroo thru ducts and dampers (Inciuding air measurement)

27. Pressure drop thru firing equipment 0.15 259 197,073 320

345,300 300
370
333 $690,000$. 384,333 1,560
$1,4.0$ 1,000
$i 4.7$ 30 660 540 320 24 24
725
625 370

301 $\div 03$

\begin{tabular}{ll}
1 & 3 \\
\hline
\end{tabular}

28. Total static pressure at fan (inches w.g.) 1.50

1.50 243 478 284 894

936 . 955 .

315

80

593

329

760,000
450

760,000 , 000
.355 
EIG RIVERS RURAL EIECTRIC COOPLRATIVE CORP. SEBRET, KENTUCK

2502

$\mathrm{PB}-8920$

Sheet-2 of 2

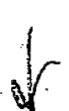

4 Hour Posh

Tog Etr

Pounds of steam per bour act. evap.

172,500

345,000

690,000

19,030

37,350

$7 I, 900$

$419,100 \cdot 763,500$

$200,600 \quad 375,700 \quad 711,700$

395,500

32. Pounds of air per hour for combustion

33. Pounds of gas per hour ent. air heater

211,200

428,400

749,200

228,000

471,800

$89 \cdot 3$

88.7

4,400

$.0,600$

812,500

864,300

35. . Overall efficiency complete unit

36. Heet release in furnace, Btu/cu.ft./hr.

37. Heat release in furnace, Btu/sq.ft.

E.P.R.S./hour

$18,100 \quad 35,800$

16,600

.9

69,900

39. Fimber of burners in operation

8

8

8.

760,000

760,000

out

$78,620 \quad 84,210$

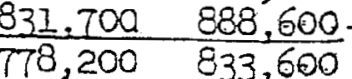

$819,200 \quad 877,500$

$888,400 \quad 951,600 ;$

$241,9001,006,600^{\circ}$

$\begin{array}{rr}86.6 & 86.4\end{array}$

EEAT BAIANCE

39. Dry flue gas loss at exit

40. Ioss due to hyorrogen and fuel moisture

2.85

4.78

3.84

0.07

41. Loss due to moisture

'?. Loss due unburned combustibles

1.00

4.92

0.09

0.50

0.50

1.50

Menufacturer?'s margin

45. Total losses

46. Efficiencies of complete unit

20.70

0.45

1.50

89.3

$1 \mathrm{I} \cdot 30$

68.7

5.53

5.19

5.80

5.21

0.13

0.25

0.50

1.50

13.10

86.9

$76, \hat{6000}$

82,000

8

MOTE: Steem temperature control $760,000 \mathrm{fl} / \mathrm{hr}$ down to $456,000 \mathrm{H} / \mathrm{hr}$. (By sprey). Eficiencies based above air tempersture entering air hecter.

The unit consists of $k-36+w . h$. Doiier, B.S. $4245 \mathrm{sq.Pt.;}$ plus projected water walls, H.S. 11,690 sq.ft.; TotaI H.S. 15.935 sq.ft.; econonizer, H.S. 5100 sq.ft.; Ijungstrom 25VIX48 air heater, E.S. 82,400 sq.ft.; superhester for 955 F.; 2 Rilley Ball Tube Millls, 8 llltA Riley burners; funnace volume 50,250 cu.ft.; Drewing LP-1098.\& A \& B.

RIIEY STOKYR CORPORATICI WORCESTER, MASSACHUSEITS $8-29-62$ D.G.T. 


\section{BABCOCK BORSIG POWER, INC.}

Nexant Inc.

WKE Reid Plant

BBP Contract 200756

4.2 Communications 


\section{ELAINE \\ STRZELEWICZ \\ 04/24/2001 03:56 PM

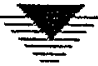

To: Frank Zone/Riley/US@Riley

cc: $\quad$ Richard Dube/Riley/US@Riley

Subject: Poultry Litter Gasification - PFD

FYl.

"Babul Patel" <bpatel@nexant.com> on 04/24/2001 02:58:56 PM

To: $\quad$ "Ellen Strzelewicz" <estrelewicz@bbpwr.com>

CC:

Subject: Poultry Litter Gasification - PFD

Ellen/ Frank:

Here is the PFD - in MS word format. The stream numbers correspond to the stream numbers identified in the Excel spread sheet.

As Frank mentioned in our Telecom, we do not have to inject the gases into the boiler @ 2250 Deg F. After the producer gas is filtered through the Hot Gas Filter and boosted to a pressure of $6 "$ WG by an ID fan, we can directly send to the boiler, if appropriate.

Babul Patel

Nexant Inc.

bpatel@nexant.com

Ph: (415)-768-1200

Fax: (415) $-768-3580$ 


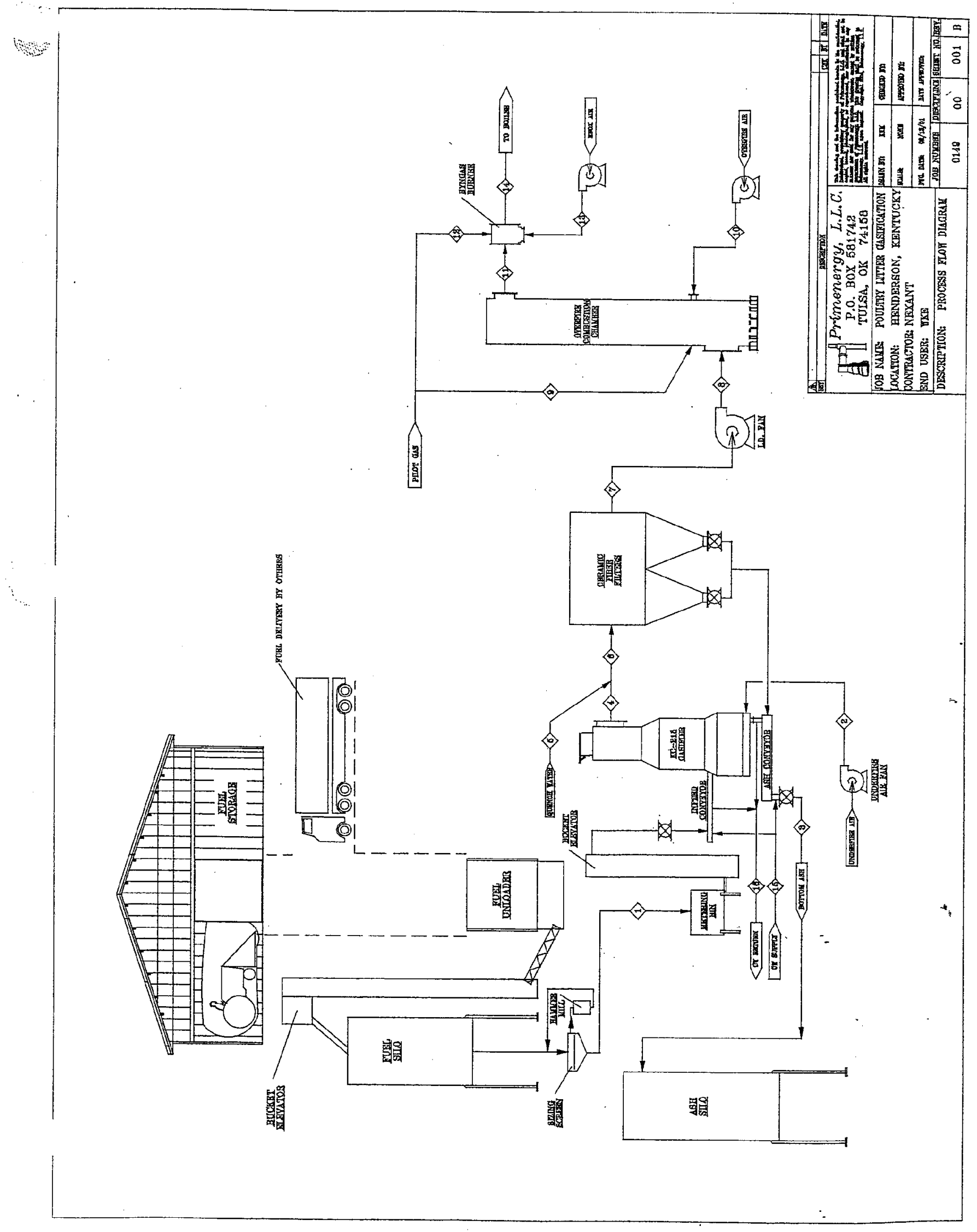




\section{ELAINE \\ STRZELEWICZ \\ 04/24/2001 03:58 PM

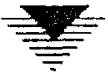

To: $\quad$ Frank Zone/Riley/US@Riley, Richard Dube/Riley/US@Riley

cc:

Subject: Western Kentucky Poultry Litter Biomass Gasification Project

FYl. Frank, I provided you copies of this data this afternoon.

Forwarded by Elaine Strzelewicz/Riley/US on 04/24/2001 03:56 PM

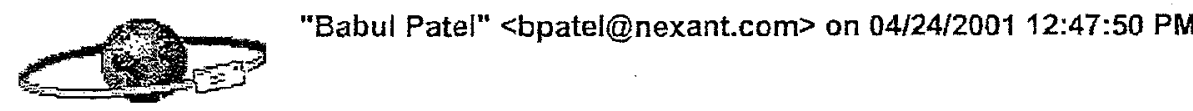

To: $\quad$ "Ellen Strzelewicz" <estrzelewicz@bbpwr.com>

CC:

Subject: Westem Kentucky Poultry Litter Biomass Gasification Project

Ellen:

Here are two files - one Excel - contains some Reid plant operating data, and expected gas composition, flow rate, temperature and pressure. The second is a word file that contains site specific information and the Riley Boiler specifications. Let me know if you will need additional information.

Thanks

Babul Patel

Nexant Inc.

bpatel@nexant.com

$\mathrm{Ph}$ : (415) -768-1200

Fax: (415) $-768-3580$

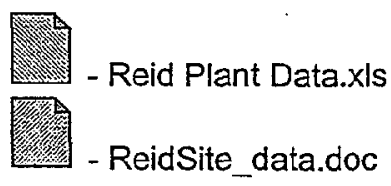


CASE I: 8.4 TPH POULTRY LI

\begin{tabular}{|c|c|c|c|c|c|}
\hline \multicolumn{3}{|l|}{ Stream ID } & 1 & 2 & 3 \\
\hline \multicolumn{3}{|l|}{ Stream } & GASIFIER & GASIFIER & GASIFIER \\
\hline \multirow{2}{*}{\multicolumn{3}{|c|}{ Name }} & FEED & COMB & BOTTOM \\
\hline & & & & AIR & ASH \\
\hline \multicolumn{3}{|c|}{ Pressure, "w.c.-g, or (psig) } & - & 20.0 & $\cdots$ \\
\hline \multicolumn{3}{|l|}{ Temperature, ${ }^{\circ} \mathrm{F}$} & 77.0 & 80.0 & 300.0 \\
\hline \multicolumn{3}{|c|}{ Molecular Weight (lb/lbmole) } & -- & 28.7 & 67.2 \\
\hline Component & Formula & MW & $\mathrm{lb} / \mathrm{h}$ & $\mathrm{lb} / \mathrm{h}$ & $\mathrm{lb} / \mathrm{h}$ \\
\hline Carbon & c & 12.01 & $4,617.3$ & & 466.9 \\
\hline Hydrogen & $\mathrm{H}$ & 1.01 & 526.6 & & \\
\hline Nitrogen & $N$ & 14.01 & 463.0 & & \\
\hline Oxygen & 0 & 16.00 & $3,416.1$ & & \\
\hline Sulfur & $S$ & 32.06 & 82.9 & & * \\
\hline Chlorine & $\mathrm{Cl}$ & 35.45 & - & . & \\
\hline Fuel Gas & $\mathrm{CH} 4$ & 16.04 & & & \\
\hline Carbon Monoxide & $\mathrm{CO}$ & 28.01 & & & \\
\hline Carbon Dioxide & $\mathrm{CO} 2$ & 44.01 & & & \\
\hline Hydrogen & $\mathrm{H} 2$ & 2.02 & & & \\
\hline Water (v) & $\mathrm{H} 2 \mathrm{O}(\mathrm{v})$ & 18.02 & & 267.1 & \\
\hline Nitrogen & N2 & 28.01 & & $20,853.3$ & \\
\hline Oxygen & $\mathrm{O} 2$ & 32.00 & & $6,312.8$ & \\
\hline Sulfur Dioxide & $\mathrm{SO} 2$ & 64.06 & & & \\
\hline Hydrogen Chloride & $\mathrm{HCl}$ & 36.46 & & & \\
\hline Ash & $\mathrm{SiO} 2$ & 60.08 & $3,494.0$ & & $3,960.9$ \\
\hline Lime & $\mathrm{CaCO} 3$ & 100.09 & & & \\
\hline Water (I) & $\mathrm{H} 2 \mathrm{O}(\mathrm{l})$ & 18.02 & $4,200.0$ & & \\
\hline TOTAL & & & $16,800.0$ & $27,433.2$ & $4,427.8$ \\
\hline AVAILABLE ENERC & ALUE (LHV-H & $\mathrm{u} / \mathrm{lb}$ & $4,051.5$ & & \\
\hline AVAILABLE ENERC & AMBtu/h & & 68.1 & & - \\
\hline FLOW RATE, scfm & & & & $6,049.9$ & \\
\hline FLOW RATE, acfm & & & & $6,282.6$ & \\
\hline
\end{tabular}




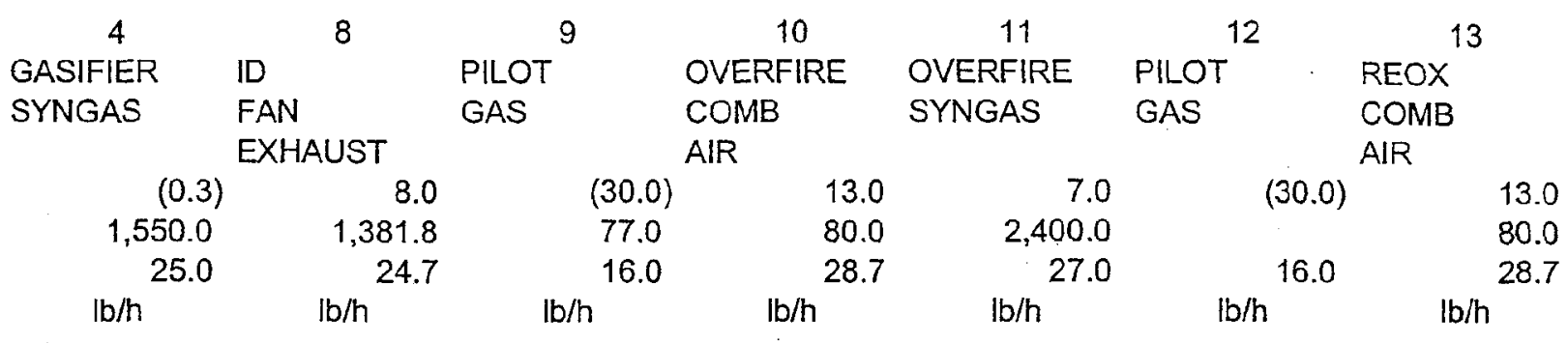

23.3

23.3

\begin{tabular}{|c|c|c|c|c|c|c|}
\hline $3,819.3$ & $3,819.3$ & & & 633.3 & & \\
\hline $9,206.7$ & $9,206.7$ & & & $14,276.2$ & & \\
\hline 421.0 & 421.0 & & & 200.4 & & \\
\hline $5,411.6$ & $6,575.7$ & & 157.0 & $8,756.2$ & & 244.6 \\
\hline $21,316.3$ & $21,316.3$ & & $\begin{array}{r}12,257.5 \\
3,710.7\end{array}$ & $33,573.7$ & & $\begin{array}{r}19,098.9 \\
5,781.7\end{array}$ \\
\hline $\begin{array}{c}165.7 \\
- \\
69.9\end{array}$ & 165.7 & & & & & \\
\hline $40,410.3$ & $41,504.6$ & 23.3 & $16,125.1$ & $57,439.8$ & 23.3 & $25,125.3$ \\
\hline 953.9 & 928.7 & $21,502.0$ & & 229.0 & $21,502.0^{\circ}$ & \\
\hline 38.5 & 38.5 & 0.5 & & 13.2 & 0.5 & \\
\hline $10,242.9$ & $10,644.2$ & 9.2 & $3,556.1$ & $13,478.1$ & 9.2 & $5,541.0$ \\
\hline $39,592.7$ & $37,701.1$ & 9.5 & $3,692.9$ & $74,129.3$ & 8.1 & $5,754.1$ \\
\hline
\end{tabular}




\begin{abstract}
14
COMB

PROD TO

BOILER

6.0

$2,330.2$

28.0

$\mathrm{lb} / \mathrm{h}$
\end{abstract}

$15,335.0$

$10,843.7$

$52,672.6$

$3,737.0$

$82,588.3$

$18,642.4$

$100,030.5$ 
Site Specific Data

Henderson, $K Y$ Area Meteorological Data Latitude: 37:45:00 N, Longitude: 87:30:00 W, Elevation: $387 \mathrm{Ft}$.

\begin{tabular}{|c|c|c|c|c|}
\hline Element & $\begin{array}{l}\text { Annual } \\
\text { Mean }\end{array}$ & $\begin{array}{c}\text { Annual } \\
\text { Minimum }\end{array}$ & $\begin{array}{c}\text { Annual } \\
\text { Maximum }\end{array}$ & Units \\
\hline Avg. Temperature & 56.9 & -20 & 113. & Deg F \\
\hline Avg. Ambient Pressure & & & & $\mathrm{IN} \mathrm{Hg}$ \\
\hline Avg. Relative Humidity & 72 & 55 & & $\% \mathrm{RH}$ \\
\hline Avg. Wind Speed & $70^{1}$ & & $74^{2}$ & MPH (UBC) \\
\hline Annual Precipitation & 44.8 & 28.25 & 71.01 & IN \\
\hline Maximum One Day & & & 6.33 & IN \\
\hline Annual Snow Fall & 16.1 & & & IN \\
\hline Maximum One Day & & & 39.5 & IN \\
\hline Seismic Zone & $1^{3}$ & & & \\
\hline
\end{tabular}

Ref: National Climatic Data Center

1. Per Uniform Building Code mean design wind speed.

2. From NOAA wind gust over 5 seconds (1930-1996 data).

3. A micro earthquake occurred at 3:04:26 AM (CDT) on Saturday, August 26, 2000.

The magnitude 2.5 event occurred $28 \mathrm{~km}$ (18 miles) ENE (61 degrees) of 20 Evansville.

The hypocentral depth is $5 \mathrm{~km}$ ( 3 miles). (Ref. - USGS website)

Indiana-Illinois-Kentucky border point is classified as Seismic Zone 2A. (UBC - 1997 Fig. 16-2) 
Boiler Specifications:

\section{Site Specific Data}

\section{REID PLANT}

Location Henderson, $\mathrm{KY}$

WKE Contract B2502

GENERAL INFORMATION

RILEY Boiler Contract No.

B2502

RILEY Boiler Serial No.

Year Built

RILEY Fuel Burning Contract No.

TM6833.

Engineers Burns and McDonnell Co., Kansas City, MO

Maximum Continuous. Capacity

Peak capacity

Type of Furnace Operation -

Drum Design Pressure

Economizer design Pressure

Operating Pressure at Superheater Outlet

Steam, Temperature at Superheater Outlet

Furnace Volume

Heat Release

(At 690,000 -lbs./hr. capacity when burning coal.)

Heat Release

(At 760,000-1bs./hr. capacity for four hrs )

Heating Surfaces (Per Manufacturer's Stamping Sheet)

Boiler

Water Walls

Superheater

Economizer

Air Heater

Approximate Water Capacity to Normal Water Level Approximate Water Capacity for Hydrostatic Test
$690,000 \mathrm{lbs}$. Steam $/ \mathrm{hr}$ $760,9000 \mathrm{lbs}$. Steam/hr. Pressurized 1475 psig 1525 psig. 1300 psig

$955^{\circ} \mathrm{F}$

$50,250 \mathrm{cu}$. ft.

$16,600 \mathrm{Btu} / \mathrm{cu} . \mathrm{ft} / \mathrm{hr}$.

19,400 Btu/cu. ft./hr.

\section{RILEY Stoker Corporation}

WORCESTER, MASSACHUSETTS 
WKE Reid Plant Bio Gasification Project

\section{Site Specific Data}

\section{Reid Plant Coal Analysis}

\begin{tabular}{|l|c|c|c|l|c|}
\hline \multicolumn{1}{|c|}{ Coal } & Average & Minimum & Maximum & \multicolumn{1}{|c|}{ Units } & Source \\
\hline As Burned Coal (LHV) & 11,986 & 11,422 & 12,296 & Btu/b. & Reid Plant Data (Y 2000) \\
Moisture & 8.6 & 7.5 & 10.8 & $\%$ & \\
Ash & 10.6 & 8.6 & 12.2 & $\%$ & $\mathbf{\nabla}$ \\
S & 2.6 & 2.3 & 2.8 & $\%$ & \\
\hline
\end{tabular}

\section{Poultry Liter Analysis}

\begin{tabular}{|l|l|l|l|l|l|}
\hline \multicolumn{1}{|c|}{ Poultry Litter } & Average & Minimum & Maximum & Units & Source \\
\hline Sample\# & & & & Btu/lb. & \\
LHV & & & & Date: \\
Moisture & & & \\
Ash & & & & \\
Volatile & & & \\
fixed Carbon & & & \\
Sulfur & & & \\
Hydrogen & & & \\
Nitrogen & & & \\
Chlorine & & & \\
Phosphorus (P) & & & \\
Potassium (K) & & & \\
Sodium (Na) & & & $\%$ & \\
\hline
\end{tabular}

\section{Reid Plant Environmental Emission Limit}

\begin{tabular}{|l|l|l|l|l|}
\hline Pollutant & PPM & lbs./MBtu & Tones/Quarter & Tones/Year \\
\hline CO & & & & \\
\hline NOx & & & & \\
\hline SOX & & & & \\
\hline Particulates & & & & \\
\hline Metals & & & & \\
\hline \multicolumn{1}{|c|}{$\mathrm{Hg}$} & & & & \\
\hline & & & & \\
\hline & & & & \\
\hline $\begin{array}{l}\text { Heat Input } \\
\text { (MBtu/hr) }\end{array}$ & & & & \\
\hline
\end{tabular}




\section{ELAINE \\ STRZELEWICZ \\ 05/03/2001 08:30 AM

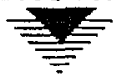

To:_Frank Zone/Riley/US@Riley, Richard Dube/Riley/US@Riley

cc: $\quad$ Enrique Vega/Riley/US@Riley

Subject: WKE - Poultry Litter

Frank, based on our conversation with Babul, please see the following.

Forwarded by Elaine Strzelewicz/Riley/US on 05/03/2001 08:20 AM

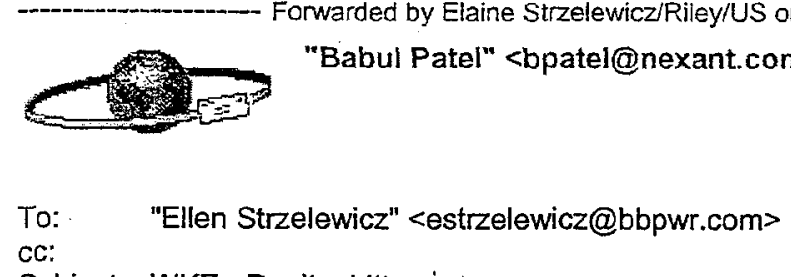

Subject: ·WKE - Poultry Litter '

After our phone conversation, I talked to our experts and gasifier vendor. The reason for over fire burner in the gasifier design is to handle Nox.

Unfortunately, poultry litter contains considerable bound nitrogen, which comes out of the gasifier as ammonia, methyl amine, NOx, etc. The gasification temperature is not sufficient to reduce these bound nitrogen compounds to N2. If oxidized directly, as it would be in the boiler, a large portion of these will convert to Nox. The result will be very high NOx emissions.

By utilizing the over fire, we provide a bigh temperature, reducing atmosphere, which reduces these bound nitrogen compounds to N2. This was the basis for our design. We are looking into cooling the gas before ID fan, but the over fire burner will be after ID fan. The Reox burner can be eliminated. I am attaching the PFD that was basis for our Material and Energy Balance.

Please pass this information to Frank and Dick Doubey. Give me a call if you think this will be a problem.

Babul Patel

Nexant Inc.

bpatel@nexant.com

Ph: (415) $-768-1200$

Fax: (415) $-768-3580$ 


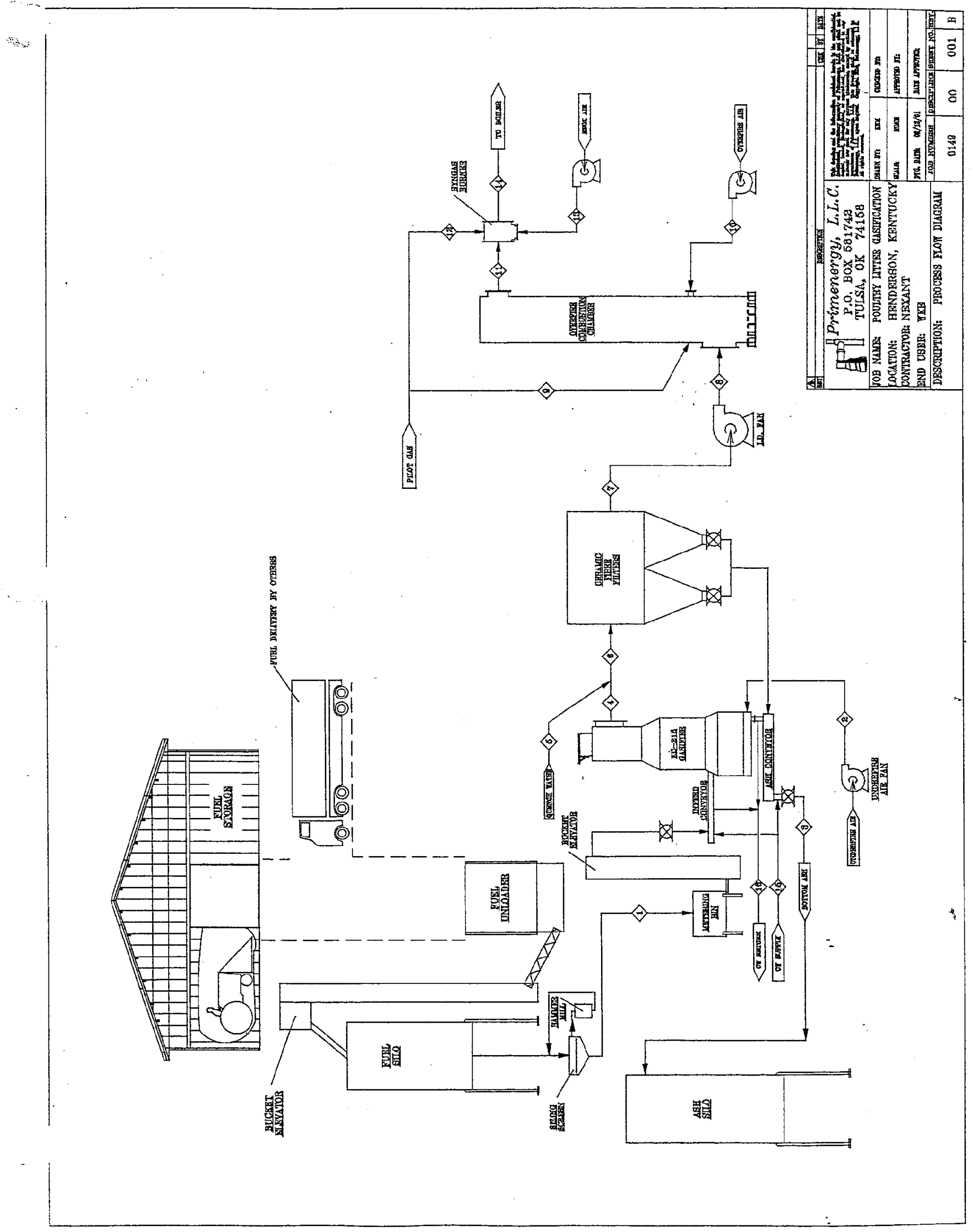




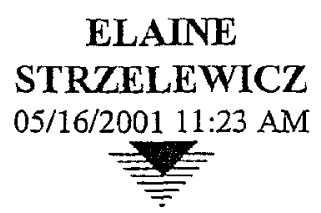

To: bpatel@nexant.com

cc: $\quad$ Frank Zone/Riley/US@Riley, Richard Dube/Riley/US@Riley

Subject: FW: Boiler Entry

BAbul, Frank needs thermal conductivity values of insulation and refractory for the pipe inside lining in order to perform his calculation.

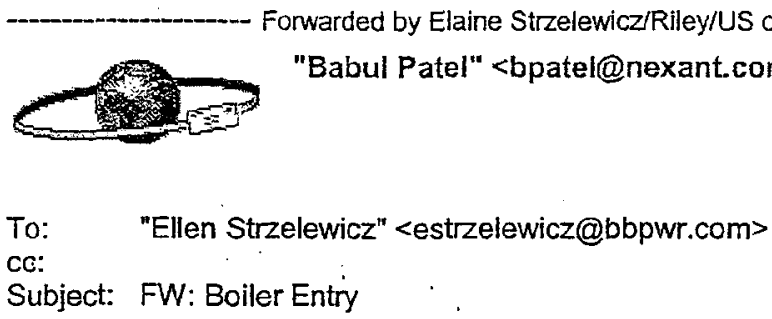

Ellen:

I had discussion with Frank and Dick about the boiler penetrations. I passed their questions and concerns to Primenergy, and I got following response. I have also left messages with refractory engineer from the past to seek his advise.

I am checking Kevin's' calculations, but 4 -38" penetrations along the side of the boiler do not look out of the ordinary. The overfire chamber is a refractory lined vessel with approx. 6' ID that will be sitting on the ground approximately $15^{\prime}$ from the boiler house. We will have to figure out how to route 4 large pipes from there into the boiler. Ideally, we would like to have the cooled gas at 1000 deg $F$ going into the boiler, but due to Nox issue, we have to burn the gas outside.

Hope, this helps. If Frank and Dick have questions, please call.

Babul patel

Nexant Inc.

bpatel@nexant.com

Ph: $(415)-768-1200$

Fax: (415) $-768-3580$

----original Message-----

From: Kevin McQuigg [mailto:kmcquigg@primenergy.com]

Sent: Tuesday, May 15, 2001 12:57 PM

To: Babul Patel (E-mail)

CC: W.N. (Bill) scott

Subject: Boiler Entry

Babul,

I am presently working on the calculations, including the flue gas to air heat exchanger downstream of the hot gas filters. As it turns out, the air preheat makes only a small difference on the gas flows. 


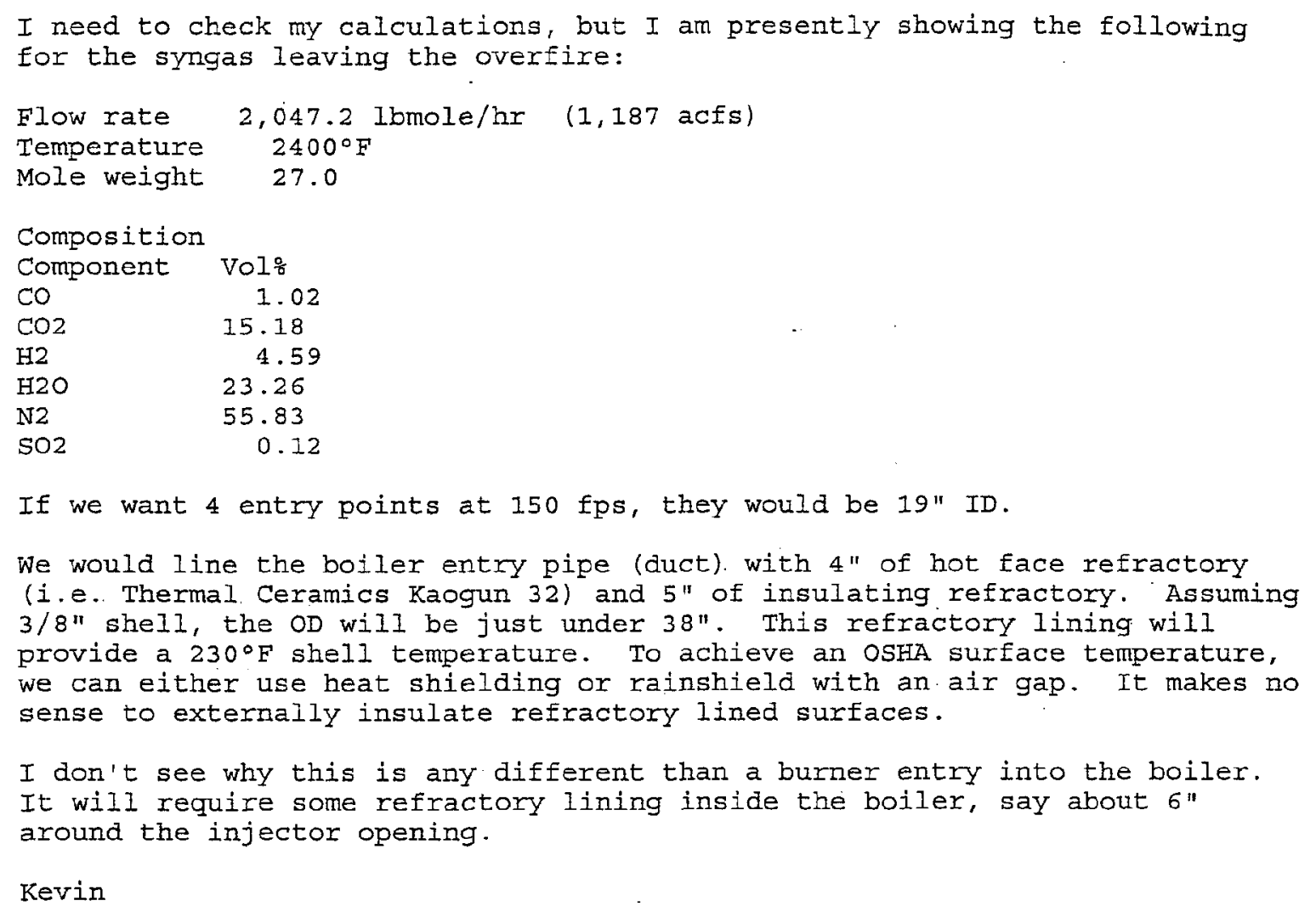

If we want 4 entry points at $150 \mathrm{fps}$, they would be 19 " ID.

We would line the boiler entry pipe (duct). with 4 " of hot face refractory (i.e. Thermal Ceramics Kaogun 32 ) and $5^{\prime \prime}$ of insulating refractory. Assuming 3/8" shell, the OD will be just under 38". This refractory lining will provide a $230^{\circ} \mathrm{F}$ shell temperature. To achieve an OSHA surface temperature, we can either use heat shielding or rainshield with an air gap. It makes no sense to externally insulate refractory lined surfaces.

I don't see why this is any different than a burner entry into the boiler. It will require some refractory lining inside the boiler, say about 6" around the injector opening.

Kevin 


\section{ELAINE \\ STRZELEWICZ \\ 05/17/2001 11:50 AM \\ =}

To: $\quad$ Richard Dube/Riley/US@Riley, Frank Zone/Riley/US@Riley

cc: Enrique Vega/Riley/US@Riley

Subject: FW: Boiler Penetration

Job 200756

Frank, here's some information for you from Babul. So, is the OD $6^{\prime}$ or $38^{\prime \prime}$ - have we verified numbers yet? Also, here äre the hours used through May 13th - Frank - 59 hours; Dick 14.5 hours

Forwarded by Elaine Strzelewicz/Riley/US on 05/17/2001 11:39 AM

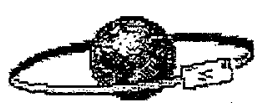

"Babul Patel" <bpatel@nexant,com> on 05/16/2001 08:50:27 PM

To: $\quad$ "Ellen Strzelewicz" <estrelewicz@bbpwr.com>

cc:

Subject: FW: Boiler Penetration

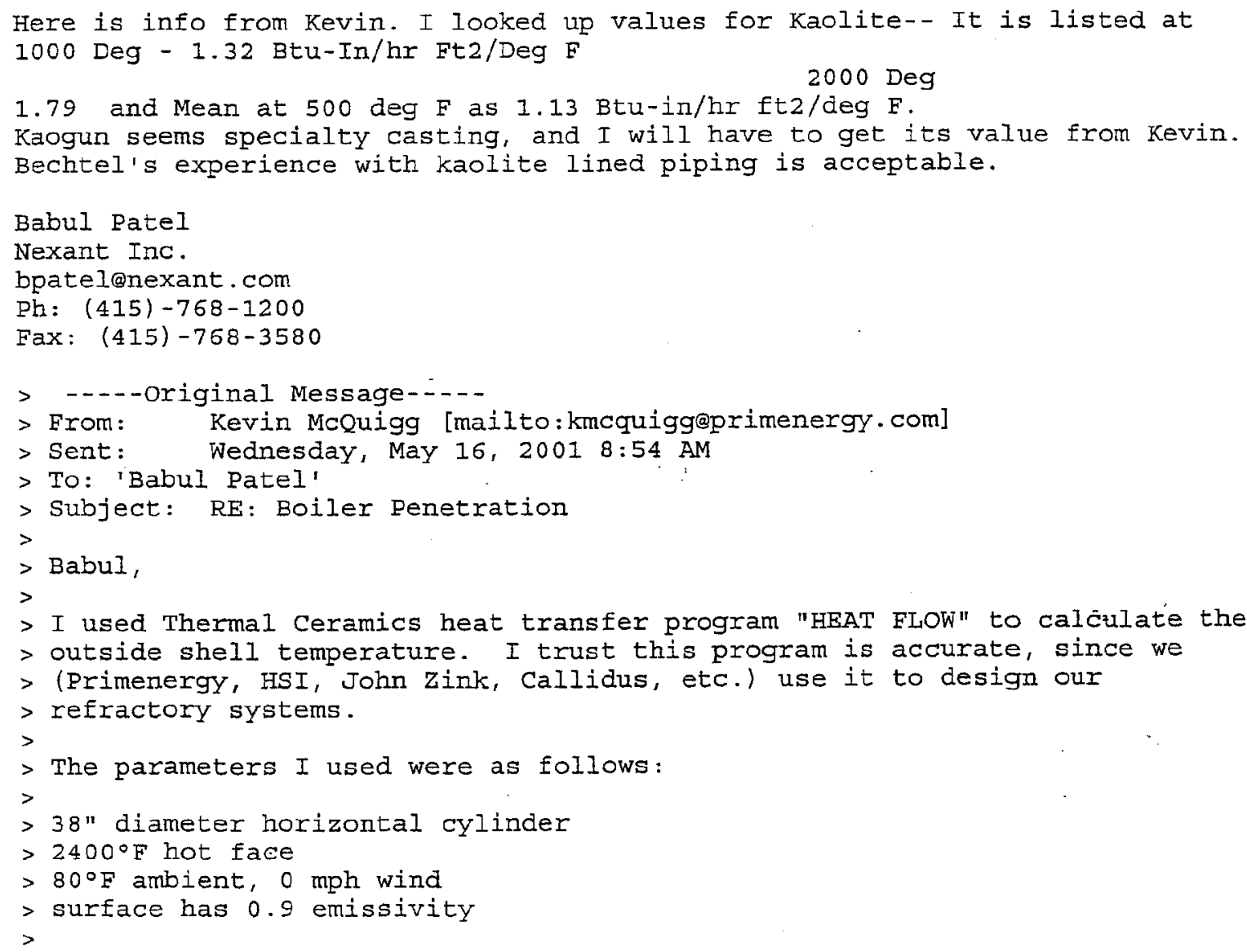




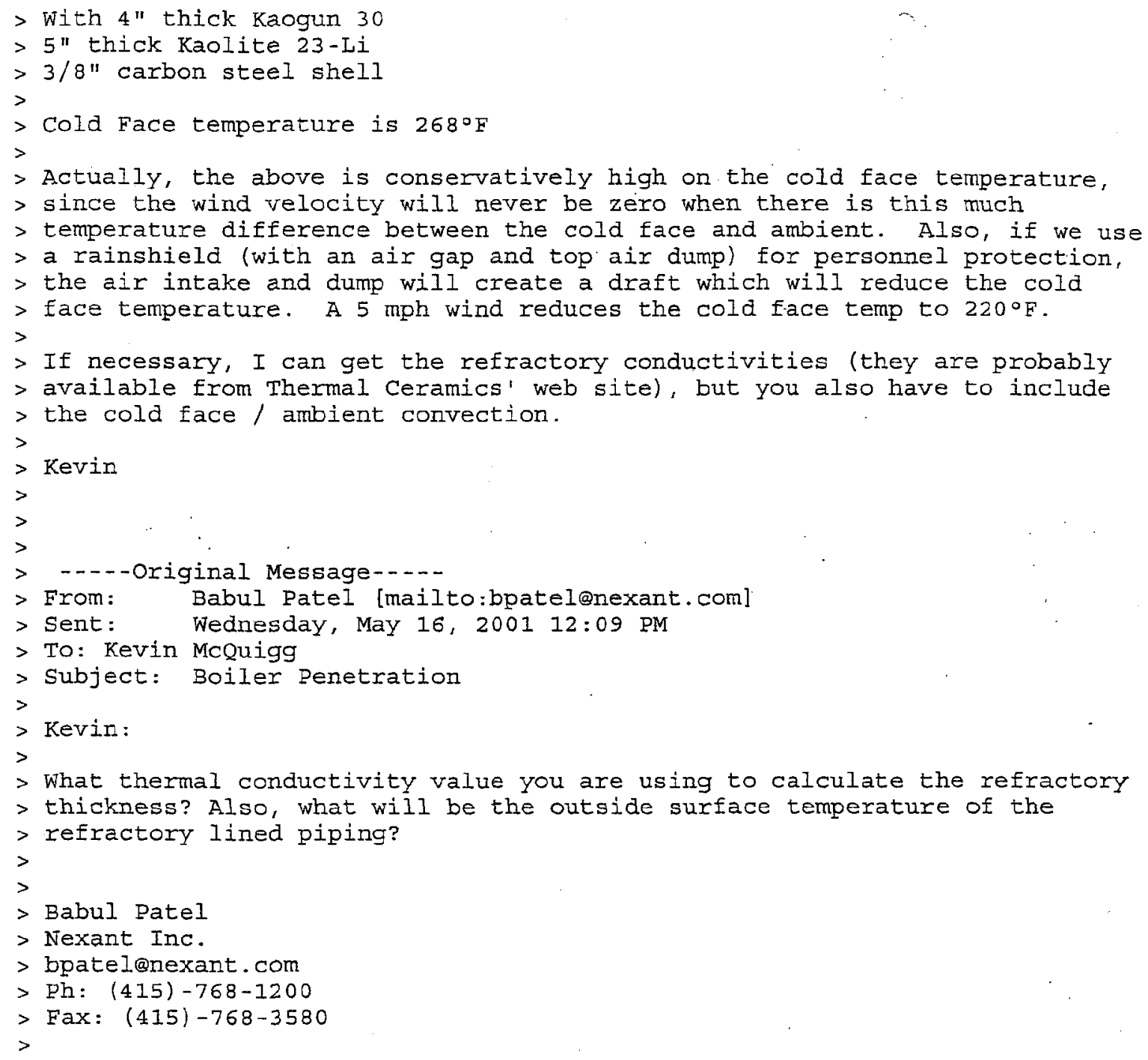




\section{ELAINE \\ STRZELEWICZ \\ 05/17/2001 01:21 PM

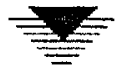

To: $\quad$ Frank Zone/Riley/US@Riley, Richard Dube/Riley/US@Riley

cc: Enrique Vega/Riley/US@Riley

Subject: FW: boiler penetration

Frank, Dick, additional information from Babul.

Forwarded by Elaine Strzelewicz/Riley/US on 05/17/2001 01:18 PM

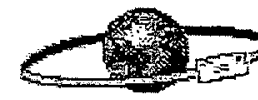

"Babul Patel" <bpatel@nexant.com> on 05/17/2001 12:27:53 PM

To: $\quad$ "Ellen Strzelewicz" <estrzelewicz@bbpwr.com>

CC:

Subject: FW: boiler penetration

Some additional info. I am tied up for today and tomorrow, but if you or Frank and Dick have questions, give me call. I will call you back ASAP if I am not at my desk.

Babul Patel

Nexant Inc.

bpatel@nexant.com

$\mathrm{Ph}:(415)-768-1200$

Fax: (415) $-768-3580$

----original Message----

From: Kevin McQuigg [mailto:kmcquigg@primenergy.com]

Sent: Thursday, May 17, 2001 5:35 AM

To: Babul Patel (E-mail)

CC: W.N. (Bill) scott

Subject: boiler penetration

Babul,

I reevaluated the refractory lining using RHI's refractory program "HEATransfer". Using 4" of hot face (Kast-O-Lite $30 \mathrm{Li} G$ ) and 5 " of insulating castable (Kast-0-Lite $22 \mathrm{G}$ ). With the same operating assumptions used for the Thermal Ceramics program -..- 3/8" shell, 38" OD, $80^{\circ} \mathrm{E}$ ambient, 0 wind, 0.9 emissivity, $2400^{\circ} \mathrm{F}$ hot face. -...- The program predicts a $335^{\circ}$ shell temperature. This is a little higher than the Thermal Ceramics prediction, but still acceptable. For sulfur plant applications, I have designed carbon steel shell temperatures as high as $500^{\circ} \mathrm{F}$.

To minimize heat loss, we can keep the boiler penetration ducts very short, coming off a main header duct. The main header could include additional refractory to keep its shell temperature lower.

Kevin 


\section{ELAINE \\ STRZELEWICZ \\ 05/18/2001 04:24 PM \\ $\Rightarrow$}

To: $\quad$ Frank Zone/Riley/US@Riley

cc: $\quad$ Richard Dube/Riley/US@Riley

Subject: Boiler Penetration

Frank, Babul has responded regarding that spreadsheet.

Forwarded by Elaine Strzelewicz/Riley/US on 05/18/2001 04:21 PM

"Babul Patel" <bpatel@nexant.com> on 05/18/2001 04:16:09 PM

To: $\quad$ "Ellen Strzelewicz" <estrzelewicz@bbpwr.com>

Subject: Boiler Penetration

Ellen:

I talked with Kevin. The attachment was something left over from his e-mail, but did not have any useful info in there. The only info I forwarded, is the result of what Jim obtained by running Thermal ceramics heat transfer program "HEAT FLOW". The program calculates optimum thickness based on flow and Temperature and does not require input of $k$ value! (they must be using the standard configuration).

The Kaogun is high alumna based refractory with $\mathrm{K}$ value of $7.5 \mathrm{Btu}-\mathrm{In} / \mathrm{hr}$ Ft2/Deg $F$ and Kaolite is value is 1.3 Btu-In/hr Ft2/Deg F.

please let me know if you need more info.

Babul Patel

Nexant Inc.

bpatel@nexant.com

Ph: (415) $-768-1200$

Fax: (4I5) $-768-3580$

- winmail.dat 